\title{
Impact of tropical rainforest transformation in Indonesia on soil carbon sources, turnover and losses
}

\author{
Dissertation \\ to attain the doctoral degree \\ „Doctor rerum naturalium"
}

of the Faculty of Forest Science and Forest Ecology

Georg-August-Universität Göttingen

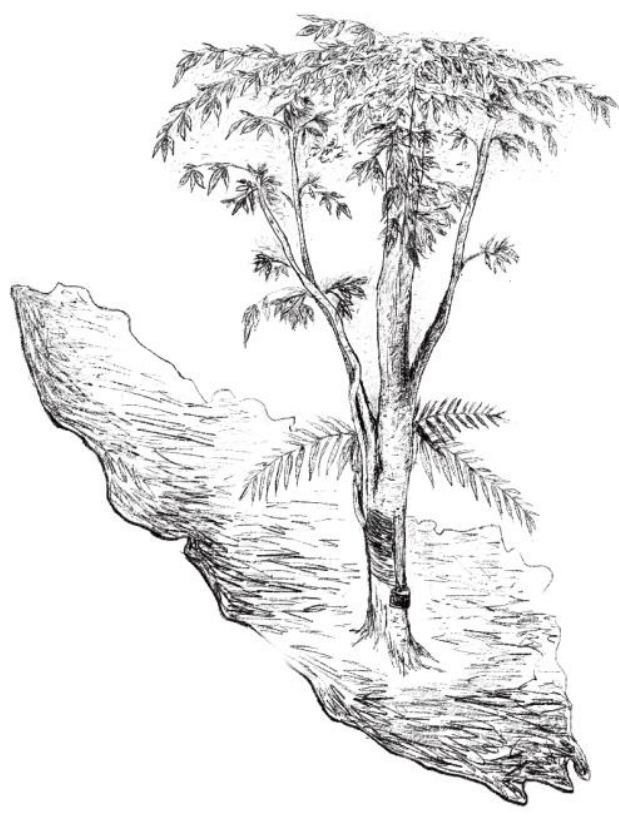

submitted by

Nina Hennings

born on the $19^{\text {th }}$ August 1986 in Uelzen

Göttingen, May 2021 
1. Referee

2. Referee

Date of oral examination: $\quad 26.08 .2021$
Prof. Dr. Michaela Dippold, Biogeochemistry of Agroecosystems, Georg-August-Universität Göttingen

Prof. Dr. Stefan Scheu, Animal Ecology, GeorgAugust-Universität Göttingen 


\section{Table of Contents}

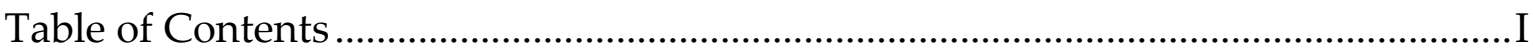

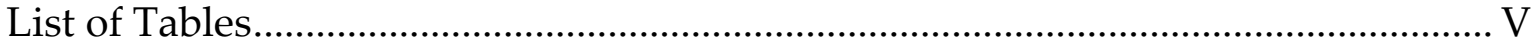

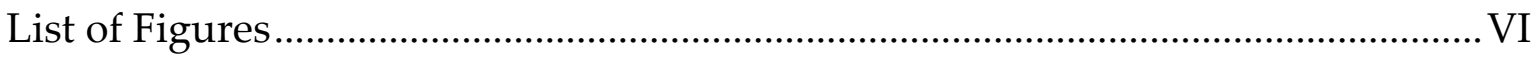

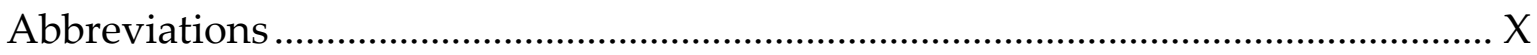

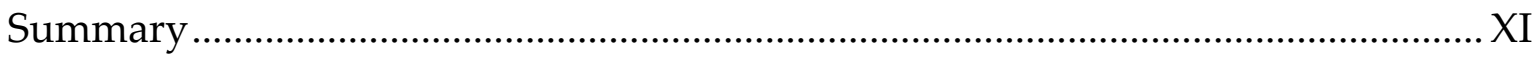

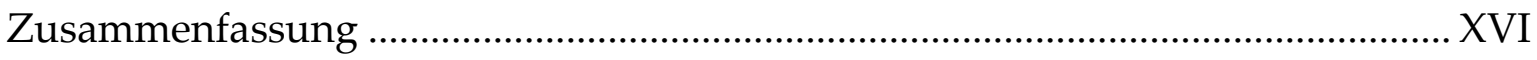

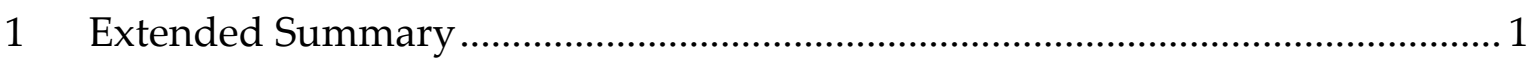

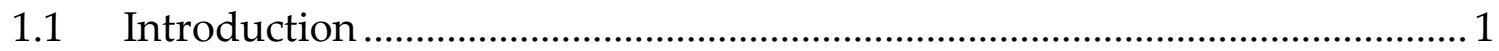

1.1.1 Global consequences of deforestation and land-use change................. 1

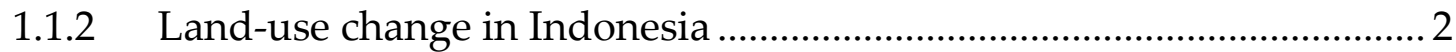

1.1.3 Functions of soil organic carbon (SOC) …............................................ 4

1.1.4 Effects of tropical land-use change on soil organic carbon .................... 5

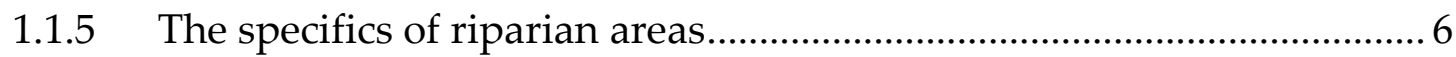

1.1.6 Sequestration potential and decomposition of SOC in well-drained

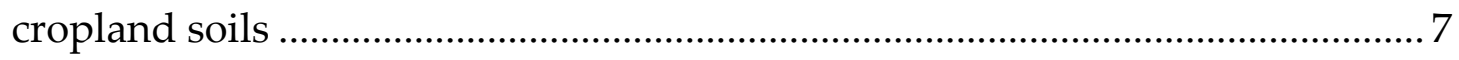

1.1.7 Objectives and Hypotheses ................................................................ 10

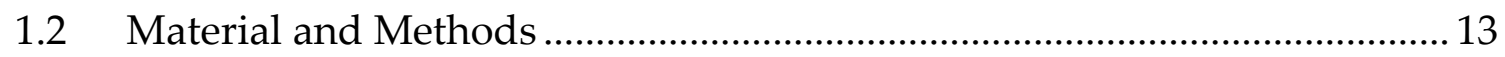

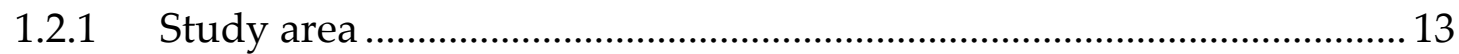

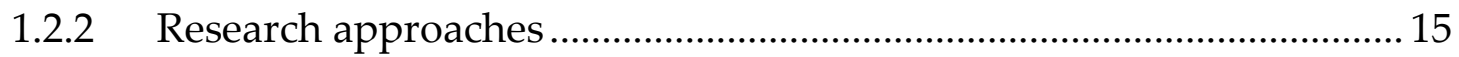

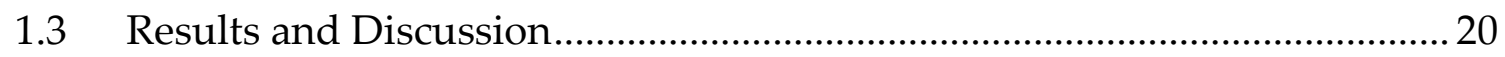

1.3.1 Land-use change and riparian effects on soil physical properties ...... 22

1.3.2 Land-use change and riparian effects on SOC stocks and

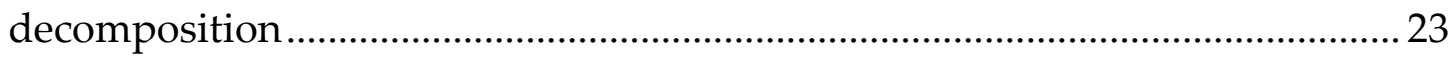

1.3.3 Reconstructing SOC sources in buried soil layers ................................. 26 
1.3.4 Contribution of forest vegetation to the current SOC pool and change of SOM composition.

1.3.5 Transformation of plant-derived lipid fingerprints by microorganisms

1.3.6 Microbial contribution to the current SOC pool .................................... 32

1.3.7 SOC decomposition under different management regimes ................ 34

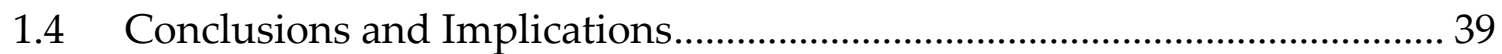

1.4.1 Landscape and land-use effects determine SOC decomposition

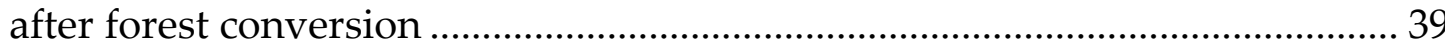

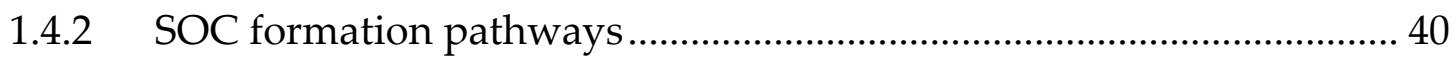

1.4.3 Management practices after land-use change affect SOC

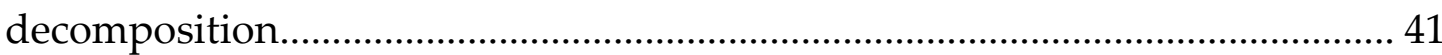

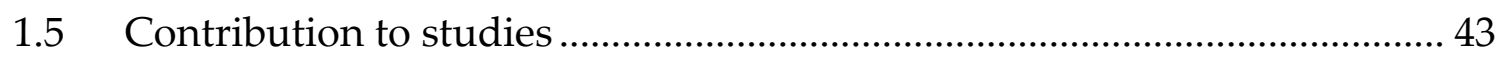

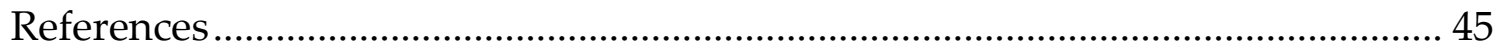

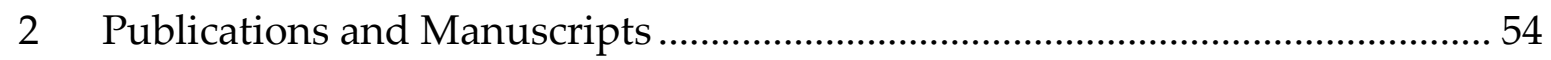

2.1 Flooding and land use change in Jambi Province, Sumatra: integrating

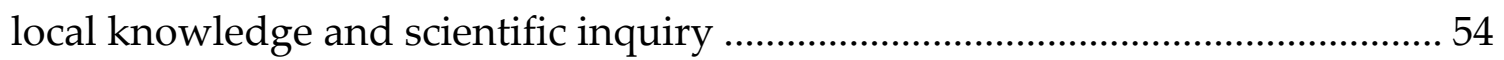

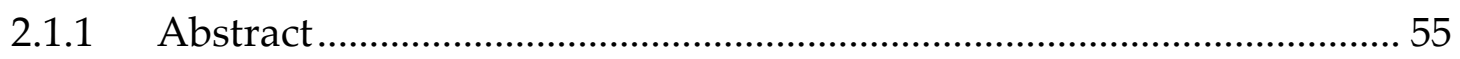

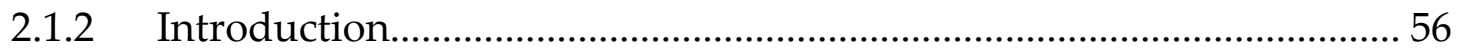

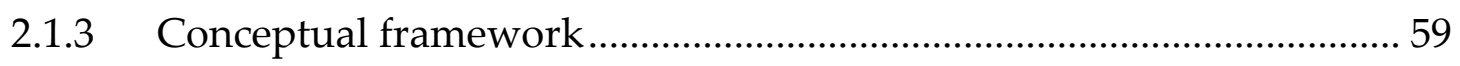

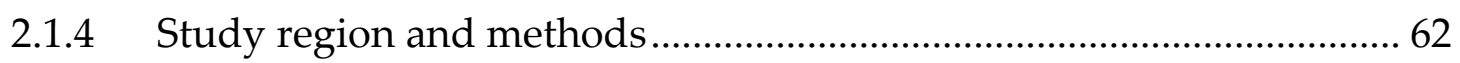

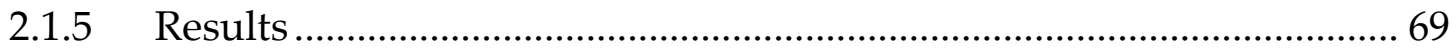

2.1.6 Discussion: integrating insights from local ecological knowledge

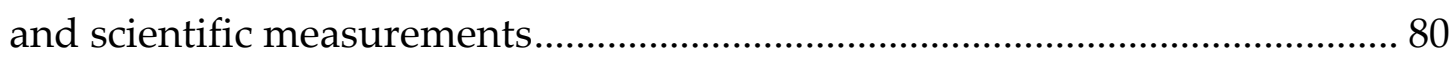

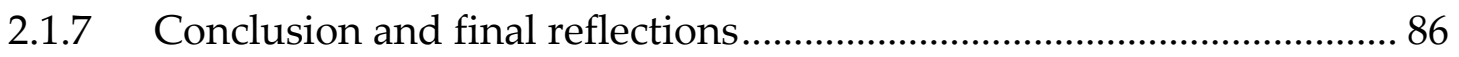

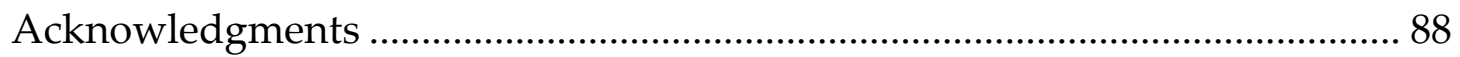

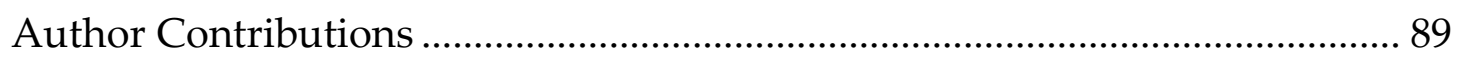

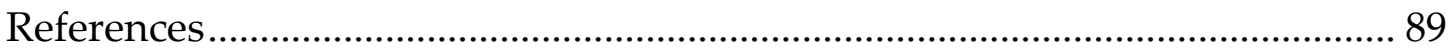


Appendix .98

2.2 Riparian wetland properties counter the effect of land-use change on soil carbon stocks after rainforest conversion to plantations 106

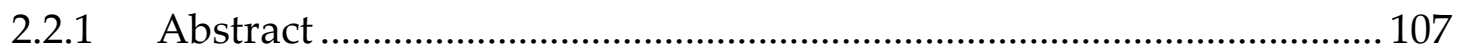

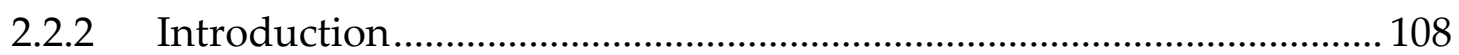

2.2.3 Materials and Methods .......................................................................... 111

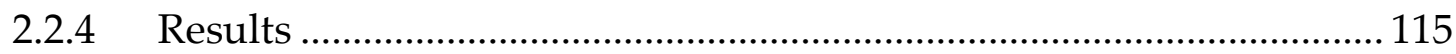

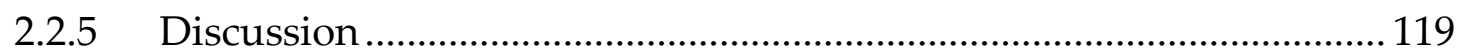

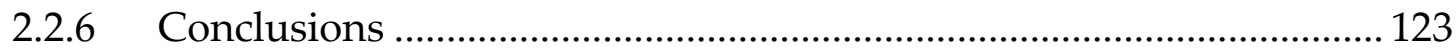

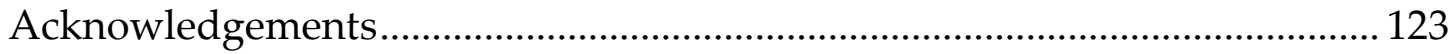

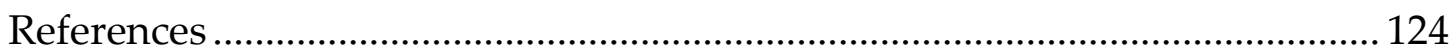

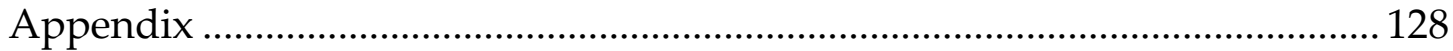

2.3 Reconstructing the sources of soil organic matter after land-use change in Indonesia using a multiple biomarker approach ............................................... 131

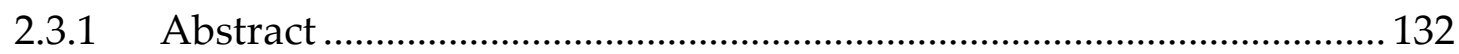

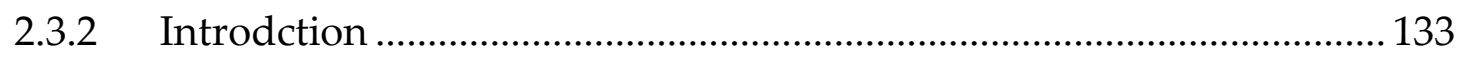

2.3.3 Materials and Methods ......................................................................... 135

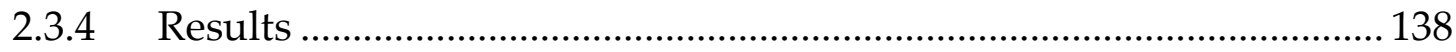

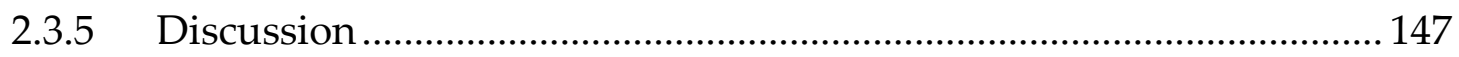

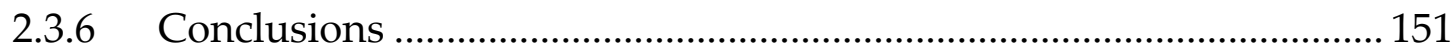

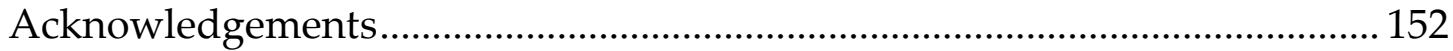

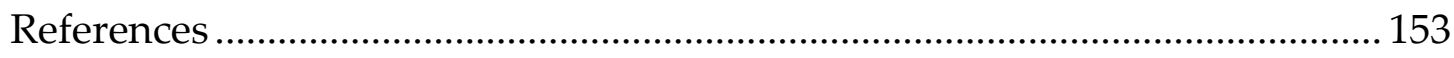

2.4 Management extensification in oil palm plantations reduces SOC

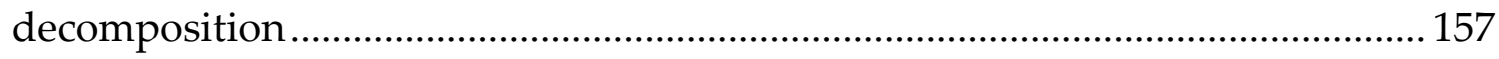

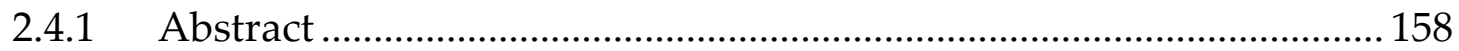

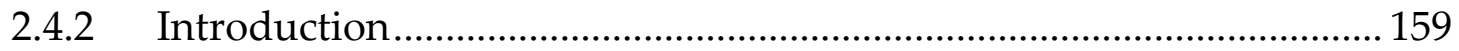

2.4.3 Materials and Methods .......................................................................... 161

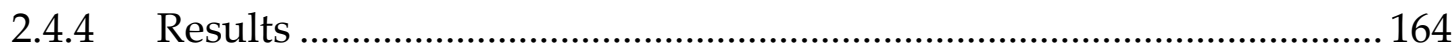




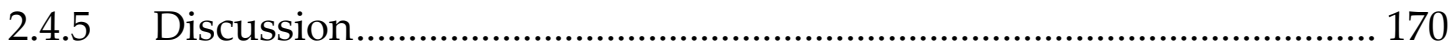

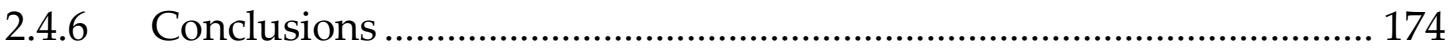

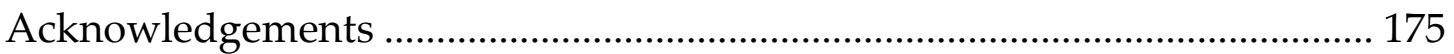

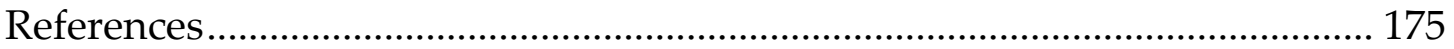

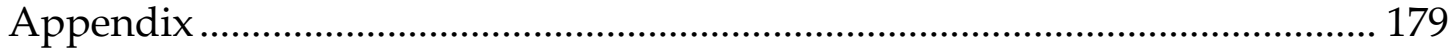

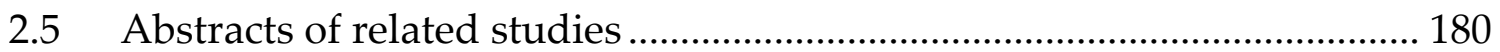

2.5.1 Soil bacterial community structures in relation to different oil palm management practices ...................................................................................... 180

2.5.2 Improving economic and environmental outcomes in oil palm smallholdings: the effects of mulching on soil carbon and yields

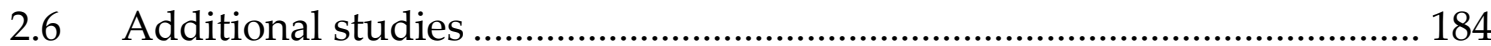

Acknowledgements …………………………………….............................XIV

Legal Statement ………………………………………............................XXVI 


\section{List of Tables}

\section{Extended Summary}

Table 1.3-1: Overview of studies included in this thesis with main objectives, results, and conclusions.

Table 1.3-2: Indicator Substances identified by Indicator Species Analysis (Study 3). Denominations in brackets represent the single or the group of $C$ pool(s) or land-use type(s), which were separated from all other $\mathrm{C}$ pools by the Indicator Species Analysis. No indicator substances were found in the alcohols/ketons fraction, which indicates that this fraction is not suitable for tracing $\mathrm{C}$ sources

Study 1

Table 2.1-1: Quotes illustrating villagers' perceptions of changing flooding regimes. (Translations by J. Merten)

Table 2.1-2: Quotes illustrating villagers' evaluations of possible causes of changing flooding regimes. (Translations by J. Merten)

Study 2

Table 2.2-1: Sampling site characteristics

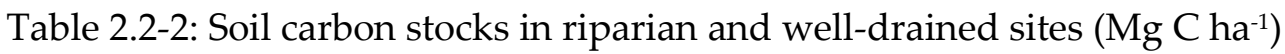

\section{$\underline{\text { Study } 3}$}

Table 2.3-1: Indicator Substances identified by Indicator Species Analysis (Study 3). Denominations in brackets represent the single or the group of $\mathrm{C}$ pool(s) or land-use type(s), which were separated from all other $C$ pools by the Indicator Species Analysis. No indicator substances were found in the alcohols/ketons fraction, which indicates that this fraction is not suitable for tracing $\mathrm{C}$ sources.

Table 2.3-2: Average chain lengths (ACL) of n-alkanes and $\mathrm{C}_{16: 1+2}{ }^{*} \mathrm{C}_{16: 0^{-1}}$ ratio of fatty acids. OEP data are presented as means $(n=4)$ with Standard Error of Means (SEM). Empty positions mean that no values for calculation were measured. 


\section{List of Figures}

\section{Extended Summary}

Figure 1.1-1: Proportion of deforestation 2001-2016 caused by each driver category, by major regions of Indonesia. Reprinted from Austin et al., 2019. This work is licensed under the Creative Commons Attribution 3.0 Unported License. To view a copy of this license, visit http://creativecommons.org/licenses/by/3.0/ or send a letter to Creative Commons, PO Box 1866, Mountain View, CA 94042, USA.

Figure 1.1-2: Forest soil profile with a buried horizon (left) and oil palm plantation soil profile with a buried horizon (right)

Figure 1.1-3: Schematic overview and picture of an (industrial) oil palm plantation: oil palms are planted in rows with $\sim 2 \mathrm{~m}$ radius weeding circles, where fertilizer and herbicide are applied. Interrows between the palms are treated with herbicide to control understory vegetation. Some interrows serve as places for piling up fronds from oil palms, presenting the only organic material input into soil

Figure 1.1-4: Overview of the aspects investigated in objective 1 (SOC stocks), objective 2 (reconstruction of $\mathrm{C}$ sources and SOM composition after landuse change), and objective 3 (management practices and their impacts on SOC decomposition and sequestration).

Figure 1.2-1: Research sites in Jambi Province. Map was produced based upon the datasets of the EFForTS

Figure 1.3-1: $\delta^{13} \mathrm{C}$ depth profiles in riparian (solid lines) and well-drained areas (dashed lines). $\delta^{13} \mathrm{C}$ values at fixed depth represent means (in riparian forest $n=3$, well-drained forest and in all plantations $n=4$ ). Error bars indicate the standard error of the mean.

Figure 1.3-2: Impact of riparian forest conversion in combination with specific ecosystem

Figure 1.3-3: n-alkanes distribution in the forest profile with a buried layer. Clear dominance of $\mathrm{C}_{31}$ and $\mathrm{C}_{33}$ compared to $\mathrm{C}_{27}$ and $\mathrm{C}_{29}$

Figure 1.3-4: Plant-derived indicator biomarkers. Boxplots show medians, interquartiles distances and extreme values, which are displayed as bold lines, boxes with whiskers and dots, respectively. Litter, roots and soil C pools are separated by grey lines. Different letters indicate significant differences according to One-Way ANOVA with TukeyHSD post-hoc comparison $(\mathrm{p}<0.05)$.

Figure 1.3-5: a) Microbial-derived biomarker. Boxplots show medians, interquartiles distances and extreme values, which are displayed as bold lines, boxes with whiskers and dots, respectively. Litter, roots and soil C pools are separated by grey lines. No significant difference (ns) could be found according to One-Way ANOVA $(\mathrm{p}<0.05)$ and $b)$ Indicator biomarker for fungi or plant origin. Boxplots show medians, interquartiles distances and extreme values, which are displayed as bold lines, boxes with whiskers and dots, respectively. Litter, roots and soil $\mathrm{C}$ pools are separated by grey lines. No significant difference (ns) could be found according to One-Way ANOVA $(\mathrm{p}<0.05)$. 
Figure 1.3-6: Cumulative Priming Effects across all management practices and locations after 33 days of soil incubation of the soil from the conventional fertilization with herbicide and mechanical weeding and reduced fertilization with herbicide and mechanical weeding. Data are presented as means $(n=4)$. Error Bars indicate the standard error of mean. Letters indicate significant differences between fertilizer, herbicide and locations according to 3-Way-ANOVA with TukeyHSD post-hoc comparison $(\mathrm{p}<0.05)$.

Study 1

Figure 2.1-1: Study region of the Tembesi watershed in Jambi Province, Sumatra, Indonesia.

Figure 2.1-2: Recently built flood control dam on an agro-industrial oil palm plantation.

Figure 2.1-3: Accumulated precipitation (a) and mean precipitation intensity index (b) at Pauh meteorological station during the period 2007 to 2016. Days within one year with water level of Tembesi River above $11 \mathrm{~m}$ (c), average change in river water level of the Tembesi River during a flash flood event (d), and fingerprint map of Tembesi River water level at Pauh hydrological station (e) during the period 1997 to 2016 (no data for 2007).

Figure 2.1-4: Land use change in the Tembesi watershed and its wetland areas between 1990 and 2013 (based on land use data by Melati 2017). Total area: Tembesi watershed $13,370 \mathrm{~km}^{2}$, wetlands $1167 \mathrm{~km}^{2}$.

Figure 2.1-5: Topsoil $(0-10 \mathrm{~cm})$ bulk densities $\left(\mathrm{BD}, \mathrm{g} \mathrm{cm}^{-3}\right)$ at 10 sites each in forest, rubber, and oil palm plantations (sites described in Drescher et al. 2016). The dots represent means and the error bars the according standard errors. Different letters represent significant differences among groups (Kruskal-Wallis test, $\mathrm{p}<0.05$ ) (left). Saturated soil hydraulic conductivity $\left(\mathrm{K}_{\mathrm{fs}}, \mathrm{cm} \mathrm{h}^{-1}\right)$ in oil palm monoculture control plots $(\mathrm{n}=4)$ and in plots within the oil palm biodiversity experiment $(n=33$; sites described in Teuscher et al. 2016). The dots represent means and the error bars the according standard errors. Different letters represent significant differences among groups (Kruskal-Wallis test, $\mathrm{p}<0.05)$ (right).

Figure 2.1-6: Development of average groundwater table at forest $(0.55 \pm 0.27 \mathrm{~m}, \mathrm{n}=$ $4)$, rubber $(1.03 \pm 0.39 \mathrm{~m}, \mathrm{n}=4)$, and oil palm $(1.24 \pm 0.50 \mathrm{~m}, \mathrm{n}=4)$ riparian locations during the period July 2017 to April 2019.

Study 2

Figure 2.2-1: Depth profiles of $\mathrm{C}$ content $\left(\mathrm{g} \mathrm{kg}^{-1}\right), \mathrm{N}$ content $\left(\mathrm{g} \mathrm{kg}^{-1}\right)$ and $\mathrm{C} / \mathrm{N}$ ratio in forest (green), rubber (blue) and oil palm (yellow) plantations. Values represent means (in forest $n=3$, in plantations $n=4$ ). Error Bars indicate the standard error of the mean (SEM).

Figure 2.2-2: Typical well-drained soil profile in one of the oil palm plantations. Classified as loamic Acrisol (WRB) (left). Typical riparian soil profile in one of the oil palm plantations. Classified as loamic Stagnosol (WRB) (middle). Forest soil profile with a buried layer in the riparian forest. 
This soil profile differs from the usual riparian Stagnosol soil type, due to the paleo soil layer leading to different diagnostic properties (right)..... 116

Figure 2.2-3: Carbon stocks of riparian and well-drained areas at 0-10, 0-30 and 0-50 $\mathrm{cm}$ soil depth. Different letters between groups indicate significant differences according to Two-Way ANOVA ( $\mathrm{p}<0.05)$.

Figure 2.2-4: $\delta^{13} \mathrm{C}$ depth profiles in riparian (solid lines) and well-drained soils (dashed lines). $\delta^{13} \mathrm{C}$ values at fixed depth represent means (in forest $\mathrm{n}=3$, in plantations $n=4)$. Error bars indicate the standard error of the mean (SEM).

Figure 2.2-5: Impact of riparian forest conversion in combination with specific ecosystem characteristics on $\delta^{13} \mathrm{C}$ distributions in the soil depth, separated in decomposition and erosion effects in well-drained areas (left) and decomposition and deposition as well as alternating oxic and anoxic conditions in the riparian areas (right).

Study 3

Figure 2.3-1: Non-metric multidimensional scaling of the entire (a) alkane, (b) fatty acid, (c) hydroxy fatty acid (d) ketones/alcohols dataset. The ordinations are based on Bray Curtis dissimilarity matrices

Figure 2.3-2: Microbial-derived biomarker. Boxplots show medians, interquartiles distances and extreme values, which are displayed as bold lines, boxes with whiskers and dots, respectively. Litter, roots and soil $\mathrm{C}$ pools are separated by grey lines. No significant difference (ns) could be found according to One-Way ANOVA $(\mathrm{p}<0.05)$

Figure 2.3-3: Indicator biomarker for fungi or plant origin. Boxplots show medians, interquartiles distances and extreme values, which are displayed as bold lines, boxes with whiskers and dots, respectively. Litter, roots and soil C pools are separated by grey lines. No significant difference (ns) could be found according to One-Way ANOVA $(\mathrm{p}<0.05)$.

Figure 2.3-4: Plant-derived indicator biomarkers. Boxplots show medians, interquartiles distances and extreme values, which are displayed as bold lines, boxes with whiskers and dots, respectively. Litter, roots and soil C pools are separated by grey lines. Different letters indicate significant differences according to One-Way ANOVA with TukeyHSD post-hoc comparison $(\mathrm{p}<0.05)$

Figure 2.3-5: Mean n-alkane distribution patterns from soil in forest, rubber and oil palm plantations. Clear odd-over-even-predominance (OEP) between $\mathrm{C}_{27}$ and $\mathrm{C}_{33}$. $\mathrm{C}_{31}$ and $\mathrm{C}_{33}$ dominance over $\mathrm{C}_{27}$ and $\mathrm{C}_{29}$. Values represented as means $(n=4)$. Error bars indicate the standard error of the mean. Newly identified $\mathrm{C}_{30 \mathrm{H} 50}$ Derivate 1 was excluded in this graph

Figure 2.3-6: Mean n-fatty acid distribution from soil in forest, rubber and oil palm plantations. Clear even-over-odd predominance (EOP) between 22:0 and 32:0. Values are presented as means $(n=4)$. Error bars indicate the standard error of the mean.

$\underline{\text { Study } 4}$

Figure 2.4-1: Scheme of the experimental design in the field (left): intensive management practices with conventional fertilization and herbicide 
application and conventional fertilization and mechanical weeding for weed control and extensive management practice with reduced fertilization and herbicide application and reduced fertilization with mechanical weeding. Typical structure of an industrial oil palm plantations (right): Weeding Circles (WC) of $2 \mathrm{~m}$ radius around each palm, where fertilizer and herbicide are applied or mechanical weeding is chosen for weed control. The interrow (IR) between the palm rows receives herbicide or is mechanically weeded but no fertilizer is applied here.

Figure 2.4-2: Basal respiration $\left(\mathrm{CO}_{2}\right)$ from incubated soil from different treatments in WC and IR. Values are presented in means $(n=4)$. Error bars represent the standard error of the mean. Letters indicate significant differences between fertilizer, herbicide and locations.

Figure 2.4-3: Metabolic quotient $\left(\mathrm{qCO}_{2}\right)$ calculated as the ratio of basal respiration to $\mathrm{C}$ in microbial biomass. Values are presented as means $(n=4)$. Error bars represent the Standard Error of Mean (SEM). Letters indicate significant differences between fertilizer, herbicide and locations according to 3Way-ANOVA on logtransformed data $(\mathrm{p}<0.05)$.

Figure 2.4-4: $\mathrm{CO}_{2}$ emission rates $\left(\mathrm{mg} \mathrm{g}^{-1} \mathrm{~d}^{-1}\right)$ from glucose and control group over the 33 days of incubation of the soil from conventional fertilization with herbicide and mechanical weeding and reduced fertilization and herbicide and mechanical weeding in WC and IR. IR did not receive fertilizer but herbicide or were mechanically weeded. Data are presented as means ( $\mathrm{n}=4$, except for the treatment "WC reduced fertilization level + herbicide" $\mathrm{n}=1$ ). Error bars indicate the standard error of the mean.

Figure 2.4-5: Cumulative $\mathrm{CO}_{2}$ emissions from glucose decomposition over the 33 days of incubation of the soil from the conventional fertilization with herbicide and mechanical weeding and reduced fertilization with herbicide and mechanical weeding. Data are presented as means $(n=4)$. Error bars indicate the standard error of the mean.

Figure 2.4-6: Cumulative Priming Effects across all management practices and locations after 33 days of soil incubation of the soil from the conventional fertilization with herbicide and mechanical weeding and reduced fertilization with herbicide and mechanical weeding. Values are presented as means $(n=4)$. Error Bars indicate the standard error of the mean. Letters indicate significant differences between fertilizer, herbicide and locations according to 3-Way-ANOVA with TukeyHSD post-hoc comparison $(\mathrm{p}<0.05)$

Figure 2.4-7: Summary of research outcomes: Decomposition responses towards contrasting management practices. Faster decomposition and higher $\mathrm{CO}_{2}$ efflux under conventional fertilization level and herbicide application. Retarded SOC decomposition and support of SOC accumulation under reduced fertilization and mechanical weeding. Effects most prominent in the WC. IRs mostly characterized by missing $C$ input and $C$ limitation. No effects of management extensification could be found in the IRs. 


\section{Abbreviations}

ACL

Average chain length

C

Carbon

$\mathrm{CO}_{2}$

Carbon dioxide

DNA

Deoxyribonucleic acid

EFB

Empty fruit bunches

EOP

Even-over-odd predominance

EPSPS

5-enolpyruvylshikimate-3-phosphate synthase

FAME

Fatty ester methyl ester

GHG

Greenhouse gas

GWT

Groundwater table

IR

Interrow

IRMS

isotope ratio mass spectrometer

K

Potassium

$\mathrm{K}_{\mathrm{fs}}$

Saturated soil hydraulic conductivity

MBC

Carbon in microbial biomass

$\mathrm{N}$

Nitrogen

NMDS

Non-metric multidimensional scaling

NPP

Netto primary production

OC

Organic carbon

OEP

Odd-over-even predominance

P

Phosphorus

PE

Priming effect

$q \mathrm{CO}_{2}$

Metabolic Quotient

RNA

Ribonucleic acid

SOC

Soil organic carbon

SOM

Soil organic matter

SPE

Soild phase extraction

WC

Weeding Circle 


\section{Summary}

Agricultural expansion is one of the most dominant drivers of deforestation word wide. The globally rising demand for cash crops such as oil palm and rubber, caused rapid agricultural expansion during the last decades, especially in South East Asia. Conversion of tropical rainforest to monocultural plantations are expected to lead to severe alterations in biogeochemical cycling and ecosystem functioning. This land-use change has major impacts on the global carbon (C) cycle as it reduces soil organic carbon (SOC) stocks, and increases carbon dioxide emissions $\left(\mathrm{CO}_{2}\right)$. Additionally, increasing demand for cash crops favors the progressive conversion of less-well accessible landscape types, such as riparian areas. Riparian areas are especially sensitive to land-use change as they are mostly characterized by higher SOC stocks than well-drained areas and are habitats for a broad range of animals as well as plant species. It is therefore crucial to understand the changes in the SOC pool and SOC fluxes under the current land-use change to assess the impact on soil $\mathrm{C}$ cycling. The aim of this research project was therefore, to identify changes of SOC sources, i.e., soil organic matter (SOM) composition, its turnover and losses after riparian forest conversion to rubber and oil palm monocultures. The study was conducted in Sumatra, Indonesia, which is a hotspot of primary forest loss due to agricultural expansion. The first objective was to determine physical and chemical changes, especially SOC stock changes of riparian soils after land-use change and to compare them with SOC stock changes in well-drained areas. The second objective was to assess the contribution of past vegetation to the current SOC pool in forest and plantation soils and to find whether there is a change of SOM composition which indicates differences in SOM sources among the land use systems. With regard to urgently needed solutions to adapt to climate change, to maintain soil fertility, and the fact that the impact of intensive nitrogen $(\mathrm{N})$ fertilization and herbicide application on the soil C cycle in these monocultures remains unknown, our last goal was to determine the effects of agricultural management practices on SOC decomposition and sequestration in oil palm 
plantations. For this purpose, a plantation with well-drained soil was selected, as greater generality can be derived from the results, since the majority of palm oil cultivation takes place on well-drained soils.

For studying the first objective, SOC stocks and $\delta^{13} \mathrm{C}$ values were determined to assess C stocks changes and SOC decomposition in four riparian forest, four riparian rubber and four riparian oil palm plantation sites and compared to the same number of well-drained sites. Average soil C stock losses from the top $30 \mathrm{~cm}$ were about $14 \%$ and $4 \%$ following conversion of riparian forest to rubber and oil palm plantations, respectively, indicating a high resistance of $\mathrm{C}$ to mineralization. C losses from well-drained areas were twice as high as from riparian areas after conversion. $\delta^{13} \mathrm{C}$ values from riparian areas showed a strong heterogeneity within the soil profile compared to well-drained profiles, indicating different degrees of decomposition of SOM. Well-drained soil profiles showed the expected pattern with lower values (-29\%o) in the topsoil and an adjustment to higher values (-26\%o) in the subsoil indicating that SOC in the topsoil was more intensively decomposed than in the subsoil. In combination with the evaluation of groundwater tables (GWT) we concluded first, alternating oxic and anoxic conditions in riparian areas caused by fluctuations in GWT and periodical flooding and consequently alternating aerobic and anaerobic decomposition processes leading to reduced SOM and litter decomposition in riparian areas. Second, due to the heterogeneous $\delta^{13} \mathrm{C}$ depth profiles, especially after land-use change, we concluded input and accumulation of allochthonous organic materials with various decomposition degrees by mineral sediments and organic matter deposition. Based on these findings we postulated a riparian landscape specific effect countering the expected land-use effect on SOC stocks. These dynamics of seasonal flooding followed by delayed mineralization are reflected by the heterogeneous $\delta^{13} \mathrm{C}$ pattern. Compared to well-drained areas, riparian areas are more resilient to short-term (1-2 decades) soil $\mathrm{C}$ loss after land-use change, indicated by similar topsoil $\mathrm{C}$ stocks as under 
natural vegetation. However, it has to be considered that they have, especially if drained, a high $\mathrm{C}$ loss potential in the long-term.

Taking into account the minor loss in SOC stocks in riparian areas after land-use change, and that $\mathrm{C}$ is preserved over a long period of time due to anoxic conditions, we determined the pools of origin of SOM constituents and the change of SOM composition and its transformation after forest conversion to plantations. For studying the second objective, we used plant-derived lipids as molecular biomarkers that can provide insights into present and past SOC input and its degree of degradation within soil. To examine whether soils from plantations reflect recent and/or past vegetation, we compared soil lipids comprising n-alkanes, carboxylic acids, alcohols and ketons in litter, roots and soil samples from primary rainforest, rubber and oil palm plantations.

By performing an indicator species analysis, we found specific substances (biomarkers) separating a single C pool in a specific land-use type or small groups of $\mathrm{C}$ pools from the other $\mathrm{C}$ pools and land-use types. This separation was indicative for higher abundances of specific substances in specific $C$ pools and in a specific land-use type. If the abundances between forest topsoil and plantation topsoil were not significant different, we assumed that there was still a contribution of past vegetation to the current SOC pool in plantations. We found both plant and microbial materials in the samples, indicating a contribution from past $\mathrm{C}$ pools.

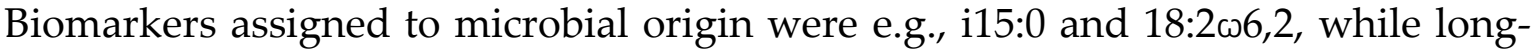
chain n-alkanes, such as $C_{25}$ and $C_{31}$ and n-fatty acids, such as 24:0, 27:0, 28:0 and 29:0 were attributed to plant material. Long-chain fatty acids, such as $24: 0$, showed similar abundances between forests and plantations, due to their long-chain $\mathrm{C}$ compounds and the associated high resistance to biodegradation. Odd-chain fatty acids like 27:0 and 29:0 are rather the products of microbial transformation of evenchain plant-derived fatty acids. Hence, we found that transformation of plantderived lipid fingerprints by microorganisms plays a key role during $C$ turnover in soil. Further indicators were used, such as the odd-over-even predominance (OEP) 
of the alkane pattern and even-over-odd predominance (EOP) of the n-fatty acids also point to a high proportion of still untransformed plant-derived SOC. Similar abundances of the hydroxy fatty acid 16-OH-16:0 were found in all soils of the three land-use types and could be clearly attributed to forest litter as an important C source still influencing plantations $\mathrm{C}$ pools. Combining multiple biomarkers, such as n-alkanes, n-fatty acids and hydroxy fatty acids helped to disentangle a complex system of pathways of SOC formation in soil.

After plantation establishment further factors influence SOC decomposition since especially oil palm plantations are commonly treated with fertilizer and herbicide for weed control. The impact of fertilization (conventional and reduced NPK) and weed control (herbicide application or mechanical weeding) on the SOC decomposition in the rows between the palms (interrows) and around the palm stems (weeding circles) was therefore studied for the third objective. ${ }^{14} \mathrm{C}$ labelled glucose was added to soil to analyze the response of microbial activity and SOC mineralization during 30-day incubation. Highest $\mathrm{CO}_{2}$ emissions were measured from weeding circles (WC) treated with the conventional fertilization level and glyphosate. The high fertilization level caused microbial activation and destabilized SOC by priming. Although glyphosate was expected to lower the microbial activity, the opposite occurred and microbial activity was highest under this treatment. An explanation might be that NPK occupies a large share of sorption capacities on soil particles; hence, glyphosate is still available and can act as an additional source of $\mathrm{C}$ and possibly $\mathrm{N}$ and $\mathrm{P}$ to microorganisms. Instead, extensive management practices (reduced fertilization + glyphosate and mechanical weeding) decreased $\mathrm{CO}_{2}$ emissions and SOC decomposition by leading to pronounced negative priming effects. Reduced fertilization and the absence of glyphosate led to strongest negative

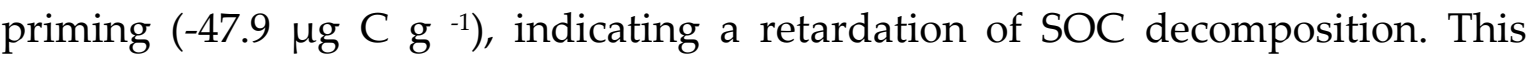
suggests a retardation of SOC decomposition and therefore positive effects on $\mathrm{C}$ accumulation and storage. In interrows (IR), respiration rates were significantly lower than in the WC, which can be explained by the lack of fertilizer application 
leading to a reduced nutrient supply for microorganisms. Usually, oil palm plantations and especially non-fertilized IR, suffer from nutrient and C limitation because of the absence of fresh litter input, low root biomass, low rhizodeposition and high nutrient leaching. Respiration data suggest that C-limitation is strong in IR across all management practices and is largely restricting the microbial activity in these soils. $\mathrm{C}$ limitation can be attributed to missing organic input e.g., litterfall or understory vegetation, which also affects $C$ sequestration in soil.

Overall, our study provides an enhanced understanding of SOC pools and fluxes affected by a) specific landscape properties of riparian areas after forest conversion to plantations and b) fertilization and herbicide management practices under oil palm cultivation. It emphasizes the vulnerability of soils in riparian areas potentially being a strong C source in the long-term, especially if drained, because they have a high SOC loss potential, but also shows a higher resilience of SOC stocks, if not drained. Changes in the molecular composition of SOM after land-use change have yet unknown implications for ecosystem function of SOM and the stability of this $\mathrm{C}$ pool. To reduce further impacts on soil a sustainable management practice should be applied under agricultural use. such as the reduction of NPK fertilizer and herbicide amendment. Our results emphasize the risk of management intensification and the need for a low-impact management strategy to maintain soil fertility and the function as a $C$ reservoir. To reach this goal, it is necessary to ensure above- and belowground $\mathrm{C}$ input i.e., by frond piling or application of empty fruit bunches as organic fertilizers. 


\section{Zusammenfassung}

Die landwirtschaftliche Erweiterung gilt weltweit als einer der wichtigsten Treiber für die Abholzung von Wäldern. Die weltweit steigende Nachfrage nach Agrarprodukten wie Palmöl und Kautschuk führte in den letzten Jahrzehnten, insbesondere in Südostasien zu einer rasanten Ausweitung der Landwirtschaft. Es wird erwartet, dass die Umwandlung von tropischem Regenwald in monokulturelle Plantagen zu schwerwiegenden Veränderungen im biogeochemischen Kreislauf und in der Funktionsweise von Ökosystemen führen wird. Dieser Landnutzungswandel hat große Auswirkungen auf den globalen Kohlenstoffkreislauf, da er den Vorrat an organischem Bodenkohlenstoff (engl. SOC) verringert und die Kohlenstoffdioxidemissionen $\left(\mathrm{CO}_{2}\right)$ erhöht. Darüber hinaus begünstigt die steigende Nachfrage nach Agrarprodukten die fortschreitende Umwandlung von weniger gut zugänglichen Landschaftstypen in landwirtschaftliche Flächen, wie z. B. Flussufergebieten. Uferbereiche reagieren besonders empfindlich auf Landnutzungsänderungen, da sie meist einen höheren SOC-Gehalt aufweisen als mineralisch terrestrische Böden und Lebensraum für eine Vielzahl von Tier- und Pflanzenarten sind. Es ist daher entscheidend die Veränderungen des SOC-Pools und der SOC-Flüsse unter den aktuellen Landnutzungsveränderungen $\mathrm{zu}$ verstehen, um die Auswirkungen auf den Kohlenstoffkreislauf im Boden zu beurteilen. Ziel dieses Forschungsprojekts war es daher, Veränderungen der SOC-Quellen, d.h. SOM-Zusammensetzung, die SOC Umsätze und die SOC Verluste nach der Umwandlung von Wald in Kautschukund Ölpalm-Monokulturen zu identifizieren. Die Studie wurde in Sumatra (Indonesien) durchgeführt, welches ein Hotspot des Regenwaldverlusts aufgrund der landwirtschaftlichen Erweiterung ist. Das erste Ziel war es, die physikalischen und chemischen Veränderungen, insbesondere die Veränderungen des SOCBestandes von Uferböden nach einer Landnutzungsänderung zu bestimmen und sie mit den Veränderungen in mineralisch terrestrischen Böden zu vergleichen. Das zweite Ziel war es, den Beitrag der vergangenen Vegetation zum aktuellen SOC- 
Pool in Wald- und Plantagenböden zu ermitteln und herauszufinden, ob es eine Veränderung der SOM-Zusammensetzung gibt, die auf Unterschiede in den SOMQuellen zwischen den Landnutzungssystemen hinweist. Im Hinblick auf dringend benötigte Lösungen zur Anpassung an den Klimawandel, die Bodenfruchtbarkeit zu erhalten und der Tatsache, dass die Auswirkungen intensiver Stickstoff (N)Düngung und Herbizideinsatz auf den Bodenkohlenstoffkreislauf in diesen Monokulturen unbekannt sind, war es das Ziel, die Auswirkungen landwirtschaftlicher Bewirtschaftungsstrategien auf den SOC-Abbau und die SOC Einlagerung in Ölpalmenplantagen zu bestimmen. Hier wurde eine Plantage mit mineralisch terrestrischem Boden ausgewählt, da eine größere Allgemeingültigkeit aus den Ergebnissen abgeleitet werden kann, da sich die Mehrheit des Palmölanbaus auf mineralisch terrestrischen Böden stattfindet.

Für das Erreichen des ersten Forschungsziels wurden SOC-Vorräte und $\delta^{13} \mathrm{C}$-Werte bestimmt, um die Veränderung der Kohlenstoffvorräte und den SOC-Abbau an vier Uferwald-, vier Kautschuk- und vier Ölpalmenplantagenstandorten zu bewerten und mit der gleichen Anzahl von mineralisch terrestrischen Standorten zu vergleichen. Die durchschnittlichen Verluste des Kohlenstoffvorrats in den obersten $30 \mathrm{~cm}$ des Bodens betrugen 14\% bzw. 4\% nach der Umwandlung von Auwäldern in Kautschuk- und Ölpalmenplantagen, was auf eine hohe Resistenz des Kohlenstoffs (C) gegenüber der Mineralisierung hinweist. Kohlenstoffverluste aus mineralisch terrestrischen Böden waren nach dem Landnutzungswandel doppelt so hoch wie aus Uferbereichen. $\delta^{13} \mathrm{C}$-Werte aus Uferbereichen zeigten eine starke Heterogenität innerhalb des Bodenprofils im Vergleich $\mathrm{zu}$ mineralisch terrestrischen Profilen, was auf unterschiedliche Grade der Zersetzung von SOM hinweist. Mineralisch terrestrische Bodenprofile zeigten das erwartete Muster mit niedrigeren Werten (- 29\%o) im Oberboden und einer Anpassung an höhere Werte (-26\%o) im Unterboden, was darauf hinweist, dass SOC im Oberboden intensiver abgebaut wurde als im Unterboden. 
In Kombination mit der Auswertung des Grundwasserspiegels (GWT) schlossen wir erstens auf wechselnde oxische und anoxische Bedingungen in Uferbereichen, die durch Schwankungen des GWT und periodische Überflutungen verursacht wurden, und folglich auf wechselnde aerobe und anaerobe Abbauprozesse, die zu reduzierter SOM- und Streuzersetzung in Uferbereichen führen. Zweitens schlossen wir aufgrund der heterogenen $\delta^{13} \mathrm{C}$-Tiefenprofile, insbesondere nach Landnutzungsänderungen, auf den Eintrag und die Akkumulation von allochthonem organischem Material mit unterschiedlichen Zersetzungsgraden durch mineralische Sedimente und die Ablagerung von organischem Material. Basierend auf diesen Ergebnissen stellen wir einen uferlandschafts-spezifischen Effekt fest, der dem erwarteten Landnutzungseffekt auf SOC-Verluste entgegenwirkt. Die Dynamik der saisonalen Überflutung, gefolgt von einer verzögerten Mineralisierung, spiegelt sich in dem heterogenen $\delta^{13} \mathrm{C}-$ Muster wider. Im Vergleich zu mineralisch terrestrischen Böden sind Böden in Uferbereichen widerstandsfähiger gegenüber kurzfristigen (1-2 Jahrzehnte) Bodenkohlenstoffverlusten nach Landnutzungsänderungen, da die Oberbodenschichten ähnliche SOC-Vorräte aufweisen wie die unter natürlicher Vegetation, jedoch muss berücksichtigt werden, dass sie, insbesondere wenn sie entwässert sind, langfristig ein hohes C-Verlustpotenzial haben.

Unter Berücksichtigung der geringen SOC-Verluste in Uferbereichen nach Landnutzungsänderung und der Tatsache, dass das organische Material aufgrund anoxischer Bedingungen über einen langen Zeitraum unverändert erhalten bleibt, haben wir die Herkunftspools der SOM-Bestandteile und die Veränderung der SOM-Zusammensetzung nach Umwandlung von Wald in Plantagen bestimmt. Für die Untersuchung des zweiten Ziels verwendeten wir pflanzliche Lipide als molekulare Biomarker, die Einblicke in den vergangenen und gegenwärtigen SOCEintrag und dessen Abbaugrad im Boden geben können. Um zu untersuchen, ob Böden von Plantagen die rezente und/oder vergangene Vegetation widerspiegeln, verglichen wir Bodenlipide, die n-Alkane, Carbonsäuren, Alkohole und Ketone 
umfassen, in Streu-, Wurzel- und Bodenproben aus primärem Regenwald, Kautschuk- und Ölpalmenplantagen. Durch die Durchführung einer IndikatorTypen-Analyse fanden wir spezifische Substanzen (Biomarker), die einen einzelnen C-Pool in einem bestimmten Landnutzungstyp oder kleine Gruppen von C-Pools von den anderen C-Pools und Landnutzungstypen trennen. Diese Trennung war ein Indiz für höhere Abundanzen bestimmter Substanzen in bestimmten C-Pools und in einem bestimmten Landnutzungstyp. Wenn die Abundanzen zwischen dem Oberboden von Wäldern und dem Oberboden von Plantagen nicht signifikant waren, nahmen wir an, dass es immer noch einen Beitrag des $C$ der vergangenen Vegetation zum aktuellen SOC-Pool in Plantagen gibt. In den Proben fanden wir sowohl pflanzliche als auch mikrobielle Stoffe, die auf einen Beitrag vergangener CPools hinweisen. Biomarker, die mikrobiellem Ursprung zugeordnet wurden, waren i15:0 und 18:2w6,2, während langkettige n-Alkane, wie $C_{25}$ und $C_{31}$ und nFettsäuren, wie 24:0, 27:0, 28:0 und 29:0, pflanzlichem Material zugeordnet wurden. Langkettige Fettsäuren, wie 24:0, weisen aufgrund ihrer langkettigen CVerbindungen und der damit verbundenen hohen Resistenz gegenüber biologischem Abbau ähnliche Häufigkeiten zwischen Wäldern und Plantagen auf. Fettsäuren mit einer ungeraden Anzahl von C-Atomen, wie 27:0 und 29:0, sind eher Produkte der mikrobiellen Transformation von geradkettigen pflanzlichen Fettsäuren. Somit stellten wir fest, dass die Transformation von pflanzlichen LipidZusammensetzungen durch Mikroorganismen eine Schlüsselrolle beim C-Umsatz im Boden spielt. Als weitere Indikatoren wurden die even-over-odd-predominance (OEP) des Alkanmusters und die even-over-odd-predominance (EOP) der nFettsäuren herangezogen, die auch auf einen hohen Anteil an noch untransformiertem pflanzlichen Ursprung des SOC hinweisen. Ähnliche Abundanzen der Hydroxyfettsäure 16-OH-16:0 wurden in allen Böden der drei Landnutzungstypen gefunden und konnte eindeutig der Waldstreu als wichtige CQuelle zugeschrieben werden, die immer noch die C-Pools der Plantagen beeinflusst. Die Kombination mehrerer Biomarker, wie z. B. n- Alkane, n-Fettsäuren 
und Hydroxyfettsäuren, hilft, ein komplexes System von Wegen der SOC-Bildung im Boden zu aufzulösen. Nach dem Aufbau der Plantage beeinflussen weitere Faktoren den SOC-Abbau, da insbesondere in Ölpalmenplantagen üblicherweise Düngemittel und Herbizide zur Unkrautbekämpfung eingesetzt werden. Ausgehend davon wurde der Einfluss von Düngung (konventioneller und reduzierter NPK) und Unkrautbekämpfung (Herbizideinsatz oder die händische Unkrautbeseitigung) auf den SOC-Abbau in den Reihen zwischen den Palmen (engl. interrows) und um die Palmstämme (engl. weeding circles) untersucht. Dazu wurde dem Boden ${ }^{14}$ C-markierte Glukose zugesetzt, um die Reaktion der mikrobiellen Aktivität und der SOC-Mineralisierung während der 30-tägigen Inkubation zu analysieren. Die höchsten $\mathrm{CO}_{2}$-Emissionen wurden von den weeding circles (WC) gemessen, die mit dem konventionellen Düngungsniveau und Glyphosat behandelt wurden. Das hohe Düngungsniveau verursachte eine mikrobielle Aktivierung und destabilisierte den SOC durch sogenanntes Priming. In Kombination mit Glyphosat nahm die mikrobielle Aktivität weiter zu. Obwohl erwartet wurde, dass Glyphosat die mikrobielle Aktivität senkt, trat das Gegenteil ein und die mikrobielle Aktivität war unter dieser Behandlung am höchsten. Eine Erklärung dafür ist, dass NPK (Stickstoff, Phosphor, Kalium) einen größeren Anteil der Sorptionskapazitäten an den Bodenpartikeln einnimmt; daher ist Glyphosat immer noch verfügbar und kann als zusätzliche Quelle für C und möglicherweise $\mathrm{N}$ und $\mathrm{P}$ fungieren. Stattdessen verringern extensive Bewirtschaftungsmethoden (reduzierte Düngung + Glyphosat und händische Unkrautbeseitigung) die $\mathrm{CO}_{2}$ Emissionen und den SOC-Abbau, indem sie zu ausgeprägten negativen PrimingEffekten führten. Reduzierte Düngung und die Abwesenheit von Glyphosat führten zu dem stärksten negativen Priming $\left(-47,9 \mu \mathrm{g} \mathrm{g}^{-1}\right)$, was auf eine Verlangsamung des SOC-Abbaus hindeutet. Dieser verzögerte Abbau weist auf damit auf positive Effekte auf die C Akkumulation und Speicherung im Boden hin. In den interrows (IR) waren die Respirationsraten deutlich niedriger als in den WC, was durch die fehlende Düngung erklärt werden kann, die zu einem reduzierten 
Nährstoffangebot für Mikroorganismen führt. Normalerweise leiden Ölpalmenplantagen und insbesondere die ungedüngten IR aufgrund des fehlenden Eintrags von frischer Streu, geringer Wurzelbiomasse, geringer Rhizodeposition und hoher Nährstoffauswaschung unter Nährstoff- und C-Limitierung. Die Respirationsdaten deuten darauf hin, dass die C-Limitierung in IR bei allen Bewirtschaftungs-methoden stark ausgeprägt ist und die mikrobielle Aktivität in diesen Böden weitgehend einschränkt. Die C-Limitierung kann auf fehlenden organischen Input, z. B. Streu oder Unterholzvegetation, zurückgeführt werden, der auch die C-Sequestrierung im Boden beeinflusst.

Insgesamt stellt die Studie ein verbessertes Verständnis der SOC-Pools und -Flüsse, die von den spezifischen Landschaftseigenschaften der Uferbereiche nach der Umwandlung von Wald in Plantagen sowie während der Anwendung von Managementpraktiken beim Ölpalmenanbau beeinflusst werden, bereit. Sie unterstreicht die Anfälligkeit von Böden in Uferbereichen, die langfristig eine starke C-Quelle darstellen können, insbesondere wenn sie entwässert werden, da sie ein hohes SOC-Verlustpotenzial haben. Veränderungen in der molekularen Zusammensetzung von SOM nach Landnutzungsänderungen haben noch unbekannte Auswirkungen auf die Ökosystemfunktion von SOM und die Stabilität dieses C-Pools. Um weitere Auswirkungen auf den Boden zu reduzieren, sollte eine nachhaltige Bewirtschaftungspraxis bei landwirtschaftlicher Nutzung angewendet werden, wie zum Beispiel die Reduzierung der NPK Düngermittelmenge und die Reduzierung von Herbiziden. Unsere Ergebnisse unterstreichen das Risiko der Bewirtschaftungsintensivierung und die Notwendigkeit einer schonenden Bewirtschaftungsstrategie, um die Bodenfruchtbarkeit und die Funktion als CSpeicher zu erhalten. Um dieses Ziel zu erreichen, ist es notwendig, den ober- und unterirdischen C-Eintrag zu gewährleisten, z.B. durch das Anhäufen von Ölpalmwedeln und das Ausbringen von leeren Fruchthülsen (engl. empty fruit bunches) als organischen Dünger und zur Unterstützung und Stabilisierung der Bodenqualität. 


\section{Extended Summary}

\subsection{Introduction}

\subsubsection{GLOBAL CONSEQUENCES OF DEFORESTATION AND LAND-USE CHANGE}

Humans have altered Earth's surface during the last century, but still about $~ 30 \%$ of the land surface of the world is covered by forest, totaling an area of 4.06 billion hectares. However, deforestation is a major environmental issue worldwide, which has led to a primary forest loss of 420 million hectares since 1990 mostly because of conversion to other land uses. Main drivers of deforestation are the expansion of forestry and agriculture. One underlying issue is the need to ensure food and energy supply for a growing world population, which causes an increasing international demand for forest products and agricultural commodities (FAO and UNEP, 2020). In temperate and boreal forests wildfires and forest management are the main causes for forest loss, while tropical forests suffer mostly from shifting agriculture and commodity-driven deforestation, such as rubber, oil palm, coffee and cacao cultivation (Burger and Smit, 2001; Curtis et al., 2018). While commodity-driven deforestation accounts for $27 \%$ of all forest loss (Curtis et al., 2018), estimations of the FAO and UNEP (2020) assume a 40\% decline of tropical forest cover between 2000 and 2010 due to large-scale commercial agriculture, and account local subsistence agriculture for another 33\%.

Deforestation is the second largest source of anthropogenic greenhouse gas emissions (GHG), after fossil-fuel combustion (Ciais, 2013) and is expected to have large adverse effects on biotic and abiotic ecosystem functions worldwide. Various studies have shown negative effects of deforestation on biodiversity, due to the loss, degradation and fragmentation of habitats (Gibson et al., 2011; Haddad et al., 2015; Rembold et al., 2017). These negative effects hold especially true for the tropics, where forests harbor approximately half of the world's species richness in only $7 \%$ of the land area (Dirzo and Raven, 2003). Abiotic ecosystem functions are reduced by deforestation, such as soil formation, carbon (C) sequestration and climate regulation (Baccini et al., 2019; Guillaume et al., 2018). Since tropical forests are coupled to the climate system through physical, chemical and biological processes negative impacts on the global climate are likely. Conversion of tropical rainforests into agricultural land therefore also has major impacts 
on the global carbon cycle, since it reduces soil organic carbon (SOC) stocks and increases carbon dioxide emissions ( $\mathrm{CO}_{2}$ ) (Don et al., 2011; Harris et al., 2012). In tropical regions SOC constitutes less than $50 \%$ of the above- and belowground C stock, while in boreal and temperate regions SOC accounts for more than $75 \%$ of the total $\mathrm{C}$ stock. Therefore, one might argue that the tropical SOC stock would play a secondary role in global soil C conservation approaches (Scharlemann et al., 2014). However, deforestation results in rapid aboveground biomass $\mathrm{C}$ loss, which is accompanied by $\mathrm{C}$ loss from soils (Guillaume et al., 2018). Therefore, tropical forests are nowadays considered to already be or to become a net C source, as additional soil C storage is unlikely and sequestered SOC is at high risk of mineralization if carbon is lost aboveground. Additionally, the average cleared tropical forest area is much higher than in boreal or temperate regions (Leblois et al., 2017), resulting in a relatively higher potential $\mathrm{C}$ loss from soil due to deforestation. The countries with the highest forest loss between 2001 and 2014 were Brazil and Indonesia, where $40 \%$ of the total tropical deforestation occured (Pendrill et al., 2019 based on Hansen et al., 2013). In 2012, Indonesia even faced the highest deforestation rate in the world ( $0.84 \mathrm{Mha}$ ) (Margono et al., 2014).

\subsubsection{LAND-USE CHANGE IN INDONESIA}

As many other countries in the Global South Indonesia has experienced a fundamental change in land cover and land use. Originally, the current Republic of Indonesia was densely forested. In addition to traditional agricultural use, such as tea, coffee, or rubber plantations, the total forest area in 1950 was estimated as $83.5 \%$ of the total land area (Tsujino et al., 2016). Increasing global demand for pulp, paper and timber led to increased international export of wooden products. Deforestation due to logging and timber production accelerated and were the largest drivers of forest loss between 1970 and 1985. Additionally, population growth in Indonesia was another indirect driver of deforestation due to urbanization and resettlement programs (transmigration programs) between 1950 and the mid-1980s (Fearnside, 1997; Tsujino et al., 2016). At the end of the 1980s the growing international demand for palm oil led to an increasing conversion of land to oil palm plantations (Tsujino et al., 2016). The main reason why palm oil production has become a rapidly expanding industry in tropical countries like Indonesia and Malaysia is the oil palm itself: it is the most efficient oil crop compared to other major oil-producing crops, such as rapeseed, soybean or sunflower. Due to its origin from equatorial Africa, it needs tropical 
conditions to grow (Corley and Tinker, 2015, p. 1 and 53). Indonesia, as a tropical country, has been the biggest producer worldwide since 2008 (FAO, 2019). During the 1990s, the Indonesian agriculture was marked by a strong expansion of large-scale and intensively managed oil palm plantations, along with increased pressure on primary and secondary forest (Tsujino et al., 2016). Oil palm plantation establishment has been acknowledged to be the dominant single driver between 2001 and 2016, responsible for 23\% of forest loss nationwide, with highest proportions in Sumatra and Kalimantan. For the whole of Indonesia, forest cover was estimated with $50 \%$ of the total land area in 2016, which is a reduction of 24\% compared to 1950 (FAO, 2019). On Sumatra Island, the expansion of small-scale agriculture and small-scale plantations plays a substantial and increasing role in relation to deforestation, especially since the end of the 2000s when forest conservation policies started to prevent further deforestation by diminishing the area for large-scale plantations (Figure 1.1-1) (Austin et al., 2019). The relative importance of other traditionally-cultivated crops, such as rubber, can vary on the regional-scale. For example, in the Province of Jambi on Sumatra Island, rubber is still one of the dominant cash-crops cultivated by smallholder farmers (Euler et al., 2016), with an increase of 30\% from 550 to $\sim 650 \mathrm{~km}^{2}$ from 1990-2011 (Clough et al., 2016). Rainforest conversion to plantations leads to extended deterioration of ecosystem functions, displayed in Jambi Province by reduction of rainforest species richness across all taxonomic groups (Grass et al., 2020) and soil fertility indicators, such as a decrease of SOC contents in top- and subsoil (Guillaume, 2015), microbial biomass, extracellular enzyme activity and phosphorus $(\mathrm{P})$ and nitrogen $(\mathrm{N})$ contents (Guillaume et al., 2016b). 


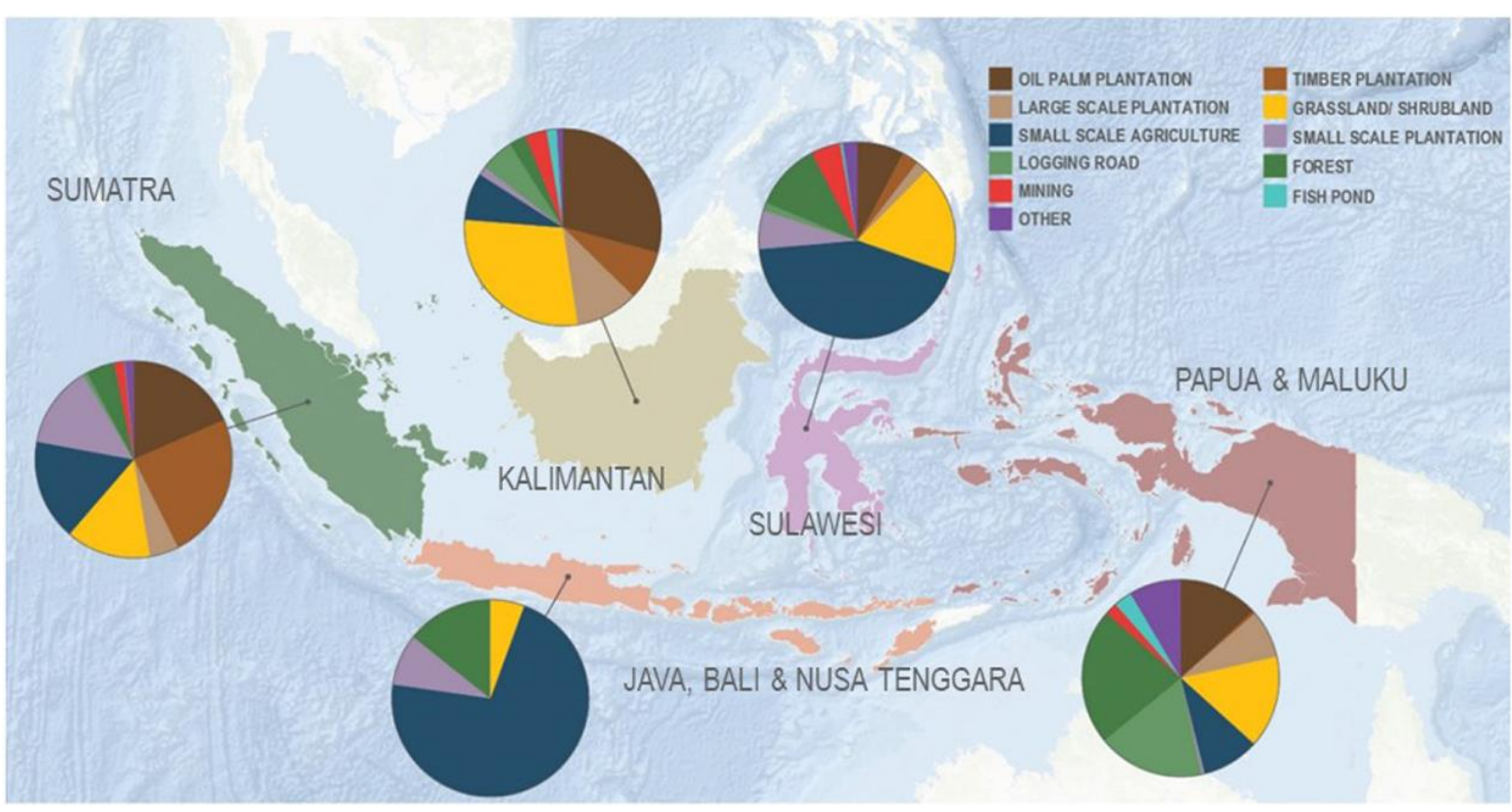

Figure 1.1-1: Proportion of deforestation 2001-2016 caused by each driver category, by major regions of Indonesia. Reprinted from Austin et al., 2019. This work is licensed under the Creative Commons Attribution 3.0 Unported License. To view a copy of this license, visit http://creativecommons.org/licenses/by/3.0/ or send a letter to Creative Commons, PO Box 1866, Mountain View, CA 94042, USA.

\subsubsection{FUNCTIONS OF SOIL ORGANIC CARBON (SOC)}

SOC is associated with properties and functions related to soil fertility. It is one of the most important factors impacting physical, chemical and biological indicators of soil quality (Reeves, 1997). SOC improves soil structural stability by promoting aggregate formation (Zhou et al., 2020). Together with soil porosity it ensures sufficient aeriation and water infiltration, supporting plant growth but also regulates soil water flow (Blanco-Canqui and Benjamin, 2013, p. 20). It is the main element ( 50\%) in soil organic matter (SOM) (Pribyl, 2010) and provides the molecular framework for SOM for covalent binding and nutrient adsorption to prevent them from leaching (Murphy, 2015). Nutrient recycling is especially important in tropical highly-weathered soils which are commonly known to suffer from low nutrient contents as they do not get nutrient input by parent material, but depend on nutrient input through litter degradation and/or the release by root exudates (Kurniawan et al., 2018; Laclau et al., 2010). Litter degradation, including SOM decomposition, leads to nutrient release and provision for plants (Kotowska et al., 2015), directly influencing plant growth and better agricultural productivity and, thus, contributing to food security. Besides providing the basis for agricultural productivity, SOC is a key indicator for environmental resilience: SOC is the second largest $C$ stock after oceans and accounts for one third of the global C storage (Jobbágy and Jackson, 2000). Although considerable variations between 
estimates exist, global SOC stocks comprise around $1500 \mathrm{GtC}$ in the first meter of soil, which is more than the $\mathrm{C}$ stock in the atmosphere $(800 \mathrm{Gt} \mathrm{C}$ ) and terrestrial vegetation (450 Gt $\mathrm{C}$ ) combined (Erb et al., 2018; Scharlemann et al., 2014). Consequently, SOC has a direct function in regulating global climate, as SOC losses might directly cause an increase of atmospheric $\mathrm{CO}_{2}$ concentration.

\subsubsection{EFFECTS OF TROPICAL LAND-USE CHANGE ON SOIL ORGANIC CARBON}

Various studies showed that the forest conversion into agricultural land is accompanied with SOC losses from mineral soils in South East Asia (Borchard et al., 2019; de Blécourt et al., 2013; Guillaume et al., 2015). In general, SOC changes are controlled by 1) the decomposition rate of SOC e.g., due to changes in microclimate and/or the increase of nutrient availability and 2) alterations in C quantity, stability and during incorporation into soil and when cycling through the system (Study 3; Kuzyakov et al., 2000; Xu et al., 2012). Land-use changes in tropical regions directly affect all these controlling factors: decomposition rates as well as quantity, stability and pathways of $C$ input (Guillaume et al., 2018). First, SOM decomposition can be increased due to sudden nutrient availability, for example, by fertilization (Study 4) or biomass burning, often occurring after slash-andburn cultivation (Juo and Manu, 1996). Second, the C quantity into soil is much lower in plantations than in forests. Kotowska et al., (2015) showed that net primary production (NPP) by litter, root and stems was reduced by $50 \%$ in rubber and in oil palm plantations (after harvest) compared to primary rainforest. Additionally, in oil palm plantations aboveground litter input in soil only occurs locally under so called frond stacks, where oil palm leaves are piled up in specific locations on the plot. other impact factors driven by land-use change are erosion and intensified mineralization which additional cause SOC losses (Guillaume et al., 2015). Erosion-induced SOC losses are often due to the removal of the C-rich surface soil layer, followed by intensified mineralization in depositional sites, where SOC is proned to mineralization due to disruption of soil aggregates during the redistribution process (Guillaume et al., 2015; Lal, 2003). These processes make erosion to be a major pathway of SOC losses after forest conversion to monocultural crop plantations. Lower SOC content after conversion may also expose the soil at high erosion risk. Additionally, higher temperatures in the tropics than in the temperate zone accelerate decomposition rates leading to high SOC losses. SOC turnover in the tropics was found to 
be twice as high as in temperate regions hinting at highly sensitive SOC stocks towards land-use change. (Six et al., 2002). Characteristics of tropical soils, additionally, favor high SOC losses: they are often low in nutrients and highly weathered and depend on nutrient input by aboveground biomass as well as by roots (Laclau et al., 2010). However, SOC losses depend on the soil type and the environmental conditions. The drainage of peat soils for example increase SOM turnover, which in turn causes elevated GHG emissions (Prananto et al., 2020). Mineral soils in riparian areas play a special role as they underlie alternating aerobic and anaerobic decomposition due to periodical flooding (Study 1,2).

\subsubsection{THE SPECIFICS OF RIPARIAN AREAS}

Definitions of riparian areas show a pronounced ambiguity. The Ramsar Convention includes riparian areas to the definition of wetlands because they defined wetlands as "areas of marsh, fen, peat land or water, whether natural or artificial, permanent or temporary, with water that is static or flowing, fresh, brackish, or salty, including areas of marine water, the depth of which at low tide does not exceed six meters" and "incorporate riparian and coastal zones adjacent to wetlands" (Ramsar Convention Secretariat, 2016, p. 9). When studying effects of flooding from a human geography perspective (Study 1), this definition encompasses different landscape types with diverging natural characteristics. For the analysis of soil properties and biogeochemical processes, however, a more precise differentiation between wetlands and riparian areas is required. Therefore, the following three distinctions were made (Study 2,3): first, riparian areas are commonly transitional zones between terrestrial ecosystems and water bodies. These areas are temporarily inundated or water-logged (Wantzen et al., 2008) with a high water table (McCormick, 1978) and can experience seasonal wet and dry cycles, i.e., temporal changes between oxic and anoxic conditions (Décamps et al., 2004). The term 'wetland', however, describes soils that are often inundated and water-saturated but do not need to be adjacent to a river. Second, related to the divergent locations, the terms describe different energy and temporal dynamics of the affecting water body. Riparian waters often reflect higher water flow dynamics where sediments are transported and material accumulation and erosion occur. Contrary, wetlands are associated with a water table that is close to or above the surface and are characterized by only a scarce flow of water (Brown et al., 1978). Third, since mineral and organic soils both occur within wetlands, the amount of organic content is not the only indicator to identify riparian areas as a certain type of wetland. The riparian SOM balance is further influenced by two specific 
factors: the redistribution of fluvial sediment (Rieger et al., 2014) and oxygen deficiency in water-saturated soil. The effects of these processes on riparian $\mathrm{C}$ balances and stabilization can offset erosion and SOM mineralization (Study 2). Sediments that enter (and partly leave) the ecotone contain high amounts of allochthonous organic material from terrestrial sources and dissolved organic matter from aquatic sources (Moore et al., 2013). Flooding duration and frequency also play crucial roles for long term $\mathrm{C}$ accumulation (Bendix and Hupp, 2000; Graf-Rosenfellner et al., 2016). Especially the redistributions of fluvial sediments provide abrupt soil horizon changes. Buried horizons as well as old paleohorizons are the results of sediment transports (Figure 1.1-2) and give a clear indication that processes of soil formation as regulated by place, climate and time can be disturbed by spontaneous material relocation events.

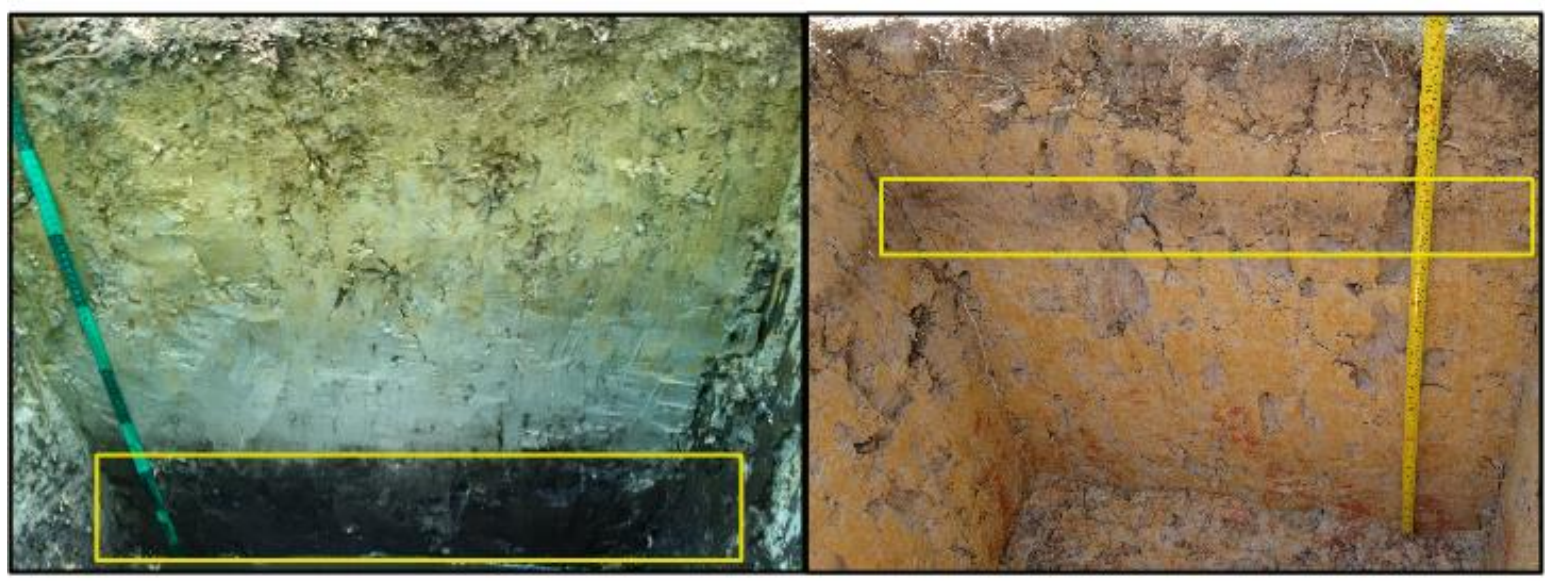

Figure 1.1-2: Forest soil profile with a buried horizon (left) and oil palm plantation soil profile with a buried horizon (right)

\subsubsection{SEQUESTRATION POTENTIAL AND DECOMPOSITION OF SOC IN WELL-DRAINED CROPLAND SOILS}

SOC sequestration is the steady build-up of $C$ storage in soil. It can be assumed that if a agricultural management practice is adopted that promotes SOC sequestration, it continues until some steady-state is achieved, as long environmental and management conditions will not change (Hutchinson et al., 2007). During and after forest conversion to croplands e.g., rubber and oil palm plantations, SOC sequestration is disrupted and SOC will become exposed to oxidative processes. Consequently, SOC decreases until a new balance will be approached. During the first years of cultivation, however, it is expected that SOC mineralization exceed the amount of new $\mathrm{C}$ entering the soil, likely resulting in high SOC 
losses (Powers, 2004). At this point, agricultural management is required to increase inputs of SOM into the soil and to decrease SOC decomposition rates and losses. Strategies for enhancing SOC stocks can be organic or mineral fertilization, returning crop residues, crop diserfication, agroforestry practices or tillage reduction, where $C$ input and management practices were found to be the main factors positively affecting SOC stocks in croplands in the tropics (Fujisaki et al., 2018). It is questionable how effective $C$ sequestration under agricultural use in terms of $\mathrm{CO}_{2}$ emission mitigation and therefore climate change adaptation can be, since $C$ sequestration in agricultural soils can only make up modest contributions around 3-6\% of fossil fuel reductions (Hutchinson et al., 2007). However, it can be a significant contribution on the local scale in terms of better soil fertility and crop productivity and therefore beneficial for the society (Hutchinson et al., 2007). Hence, maintaining and improving soil quality as well as mitigating GHG emissions are essential if agricultural and environmentally sustainability should last for future generations.

Research on above- and belowground $C$ sequestration potential of rubber and oil palm plantations is scarce and does not provide a consistent picture because studies vary strongly in their initial research questions and/or methodological approaches (Blagodatsky et al., 2016; Kongsager et al., 2013; Rüegg et al., 2019; Smith et al., 2012). Several studies found that, especially rubber plantations can have a high potential of aboveground $C$ as well as belowground $\mathrm{C}$ sequestration, however all authors limited this to fallow land or grassland conversion to rubber plantations and pointed out strong $\mathrm{C}$ losses after old-grown forest conversion to rubber plantations (Blagodatsky et al., 2016; Kongsager et al., 2013). What can be stated, however, is that rubber plantations offer the highest aboveground $\mathrm{C}$ sequestration potential in direct comparison to cacoa, orange and oil palm plantations (Kongsager et al., 2013). C sequestration potential was estimated with $214 \mathrm{t} \mathrm{C} \mathrm{ha-1}^{-1}$ for rubber plantations, while oil palm plantations' C sequestration potential was found to be lowest with $45 \mathrm{t} \mathrm{C} \mathrm{ha}^{-1}$. (Kongsager et al., 2013). Time after land-use change and the conversion type are two important factors when determining $C$ sequestration potential. Unlike rubber plantations where the soil is often uniformly covered by litter and grass, oil palm plantations frequently lack such an equally distributed organic material input into soil (Guillaume et al., 2016a). The challenge of a sustainable and spatial evenly distributed agricultural management is the spatial order in oil palm plantations. Oil palms are planted in rows and have so-called weeding circles (WC), where, herbicide and fertilizers are 
applied. Between the tree rows, the so-called interrows (IR), used for walking and harvesting, do not receive fertilizers but herbicides. Further, frond stacks are not distributed evenly throughout the plantation but piled together in rows in every second or third IR (Figure 1.1-3). In terms of $C$ input into soil it means that only the soil below frond stacks receives $C$ by litter input and the soil close to palms by root exudation. An oil palm plantation chronosequence study (Smith et al., 2012) determined the SOC sequestration potential between 11- and 34-years old plantations, where no significant increase of the SOC stock could be found. However, root biomass increased close to trees with plantation age, implying at least a short-term increase in the total belowground $\mathrm{C}$ storage. This is underlined by findings of Rüegg et al. (2019), who found fine root biomass to be one of the major drivers of SOC stabilization. Furthermore, fertilization impacts SOC accumulation (Study 4). Fertilization increases the nutrient uptake of plants, resulting in leaf litter enriched in macronutrients. The higher litter quality as well as a higher microbial activity, triggered by fertilization, increases $C$ and nutrient turnover rates in soil leading to a decrease in SOC stocks (Becker et al., 2015) shown by higher soil respiration (Study 4). In terrestrial ecosystems, soil microorganisms are mainly $\mathrm{C}$ and energy limited (Hobbie and Hobbie, 2013; Soong et al., 2020). If fresh C is provided, e.g., from root exudates (mostly sugars) of understory biomass or oil palms fronds themselves, energy becomes available. This leads to a faster nutrient turnover and to a higher nutrient demand. Hence, microbial growth and activity is stimulated, leading to extra mining of nutrients from SOM and causing an accelerated decomposition. This process is called positive priming by nutrient mining (Fontaine et al., 2003; Kuzyakov et al., 2000). Contrary, microorganisms may preferentially use mainly the easily available C source, and do not mine extra nutrients out of "older" organic matter, if required nutrients are sufficiently available. This preferential microbial substrate utilization causes negative priming effects, leading to reduced decomposition (Blagodatskaya et al., 2007; Kuzyakov and Bol, 2006). An additional factor influencing SOM decomposition might be chemical weed control. In oil palm plantations, glyphosate, a non-selective broad-spectrum herbicide, is commonly used for the control of understory vegetation. It prevents plant growth by deactivating the enzyme 5enolpyruvylshikimate-3-phosphate synthase (EPSPS), which synthesizes amino acids essential for plant survival (O Duke and Powles, 2008). The synthesizing pathway is called shikimate pathway and is also present in microorganisms, which degrade glyphosate 
(Mamy et al., 2016; Nguyen et al., 2016; Van Bruggen et al., 2018). Although microorganisms are not target organisms, glyphosate might impact their activity and growth (Pollegioni et al., 2012) and consequently SOC decomposition (Study 4). Some results showed that glyphosate changes the soil microbial community composition (Van Bruggen et al., 2018), wile other studies did not find any effects on microbial communities (Zabaloy et al., 2016). It is further assumed that the impact of glyphosate on microorganisms depends on soil properties, especially $\mathrm{pH}$, SOC content and texture (Nguyen et al., 2016). A reduction of herbicide, however, would be beneficial for soil macrofauna diversity (Ashton-Butt et al., 2018) and a reduction in SOC decomposition (Study 4). If a plantation is extensively managed, empty fruit bunches (EFB) are applied to the weeding circles instead of mineral fertilizer. This conservation practices showed to be highy effective in improving soil $\mathrm{pH}, \mathrm{C}$ input into soil, soil fauna feeding activity and thus soil ecosystem functioning (Ashton-Butt et al., 2018; Comte et al., 2013; Tao et al., 2016).

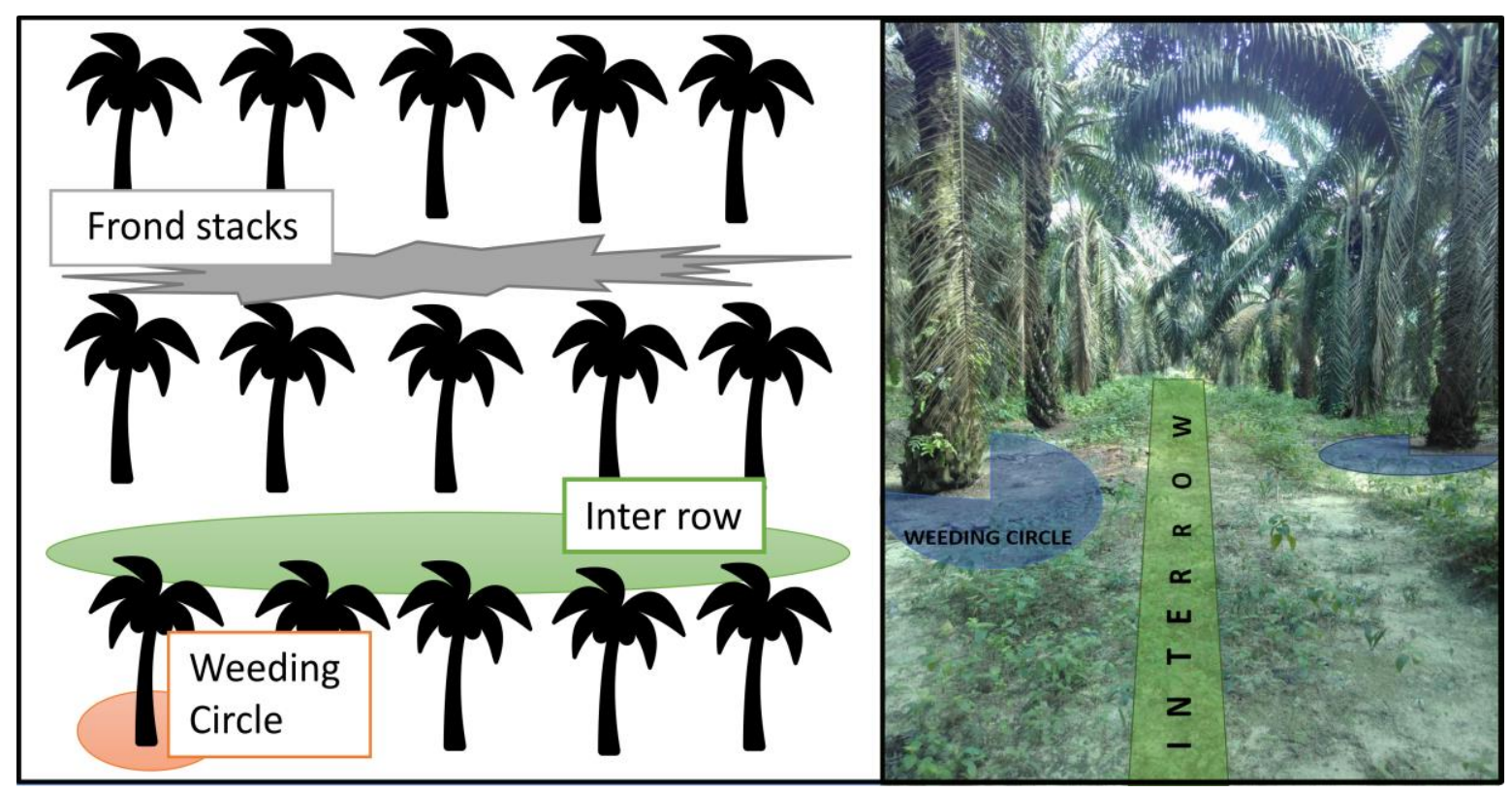

Figure 1.1-3: Schematic overview and picture of an (industrial) oil palm plantation: oil palms are planted in rows with $\sim 2$ radius weeding circles, where fertilizer and herbicide are applied. Interrows between the palms are treated with herbicide to control understory vegetation. Some interrows serve as places for piling up fronds from oil palms, presenting the only organic material input into soil.

\subsubsection{OBJECTIVES AND HYPOTHESES}

In this dissertation the main research questions were 1) how land-use change affects SOC stocks, losses and SOM composition in rubber and oil palm plantations in riparian areas compared to well-drained areas after forest conversion and 2) how different agricultural management practices reduce the SOC decomposition and thus counteract the losses 
observed in well-drained oil palm plantations. For this purpose, a plantation with welldrained soil was selected, as greater generality can be derived from the results, since the majority of palm oil cultivation takes place on well-drained soils. The knowledge derived from the individual studies (Study 1,2,3) could serve as a prerequisite for predicting future impacts on less-accessible landscapes, such as riparian areas, that are being transformed under intensively increased pressure from agricultural land expansion. At the same time, it is the aim to offer insights into the effect of management practices of contrasting intensities on SOC decomposition in a well-drained oil palm plantation (Study 4). To answer these overarching research questions, the following specific research objectives and hypotheses were established:

Objective 1: The first objective was to assess physical and chemical changes, especially SOC stocks, of soils after land-use change from primary rainforest to rubber and oil palm plantations in riparian areas (Study 1,2,3).

Hypotheses: We expected (a) that after land-use change bulk densities increase and water infiltration decreases due to soil compaction during the transformation process, while (b) SOC stock decreases stronger in riparian areas than in well-drained areas because oxidative decomposition processes are accelerated when flooded areas are aerated after conversion. Taking into account geomorphological processes in riparian areas, such as erosion and deposition occurring due to flooding, (c) SOM transport and deposition, instead of SOC mineralization, is hypothesized to be the dominant factor influencing SOC stocks.

Objective 2: The second objective was to assess 1) the contribution of past vegetation to the current SOC pool in forest and plantation soils and 2) whether there is a change of SOM composition which indicates differences in SOM sources among the land use systems (Study 3).

Hypotheses: Based on the findings of objective 1 hypothesis $\mathrm{b}$ that $\mathrm{C}$ is preserved over a long period of time in riparian areas due to anoxic conditions, we hypothesized that (a) there is still a significant contribution of past forest vegetation to the SOC pool of plantations, because rainforest litter is deposited and buried in soils and sediments. Considering that lipids derived from plants are relatively resistant against degradation, we expect to detect substances originally produced in the forest, in plantations soils and (b) after land-use 
change a relative decrease in litter $C$ input leads to a relative increase in micobial biomass and consequently to microbial necromass contribution to SOM.

Objective 3: The third objective was to determine the effects of agricultural management practices on SOC decomposition and sequestration in oil palm plantations (Study 4). With regard to urgently needed solutions to adapt to climate change, it was the aim to assess the SOC decomposition mechanisms of oil palm plantations. Therefore, we compared one of the most common management practices (mineral fertilizer and herbicide application) to a more extensive management practice, where the amount of fertilizer was reduced and herbicide application was substituted by mechanical weed control (Study 4).

Hypotheses: We hypothesized that (a) a high fertilization level leads to faster SOC decomposition and, thus increased soil $\mathrm{CO}_{2}$ emissions, by reducing microbial nutrient limitation while $(\mathbf{b})$ herbicide application increases SOC sequestration, as it counteracts the fertilizers' effects by hampering soil microbial activation, due to inhibiting the enzyme EPSPS and interfering with the shikimate synthesis pathway which is not only present in plants but also in microorganisms. Thus, we expect decreased microbial respiration, due to a disruption of microbial growth and activity (Study 4).

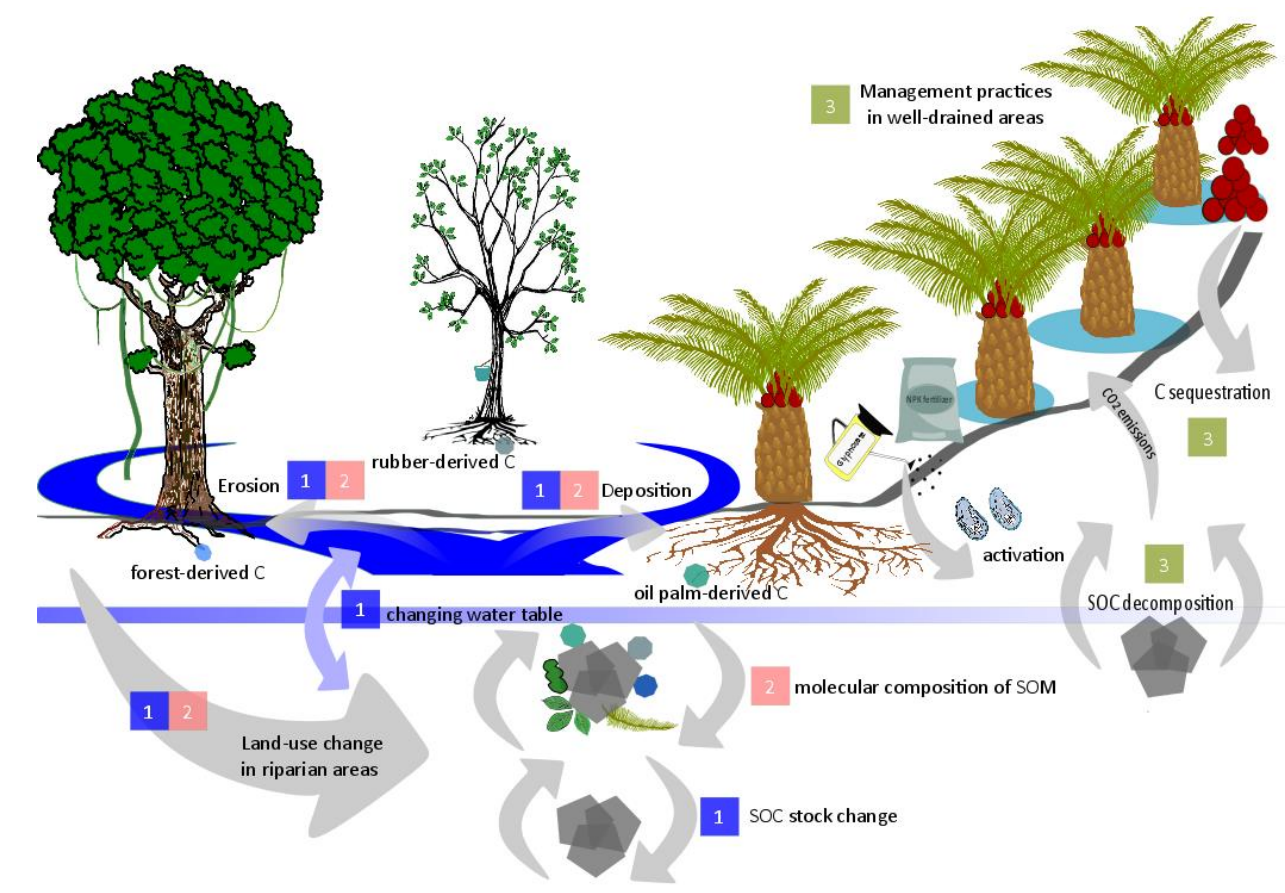

Figure 1.1-4: Overview of the aspects investigated in objective 1 (SOC stocks), objective 2 (reconstruction of $C$ sources and SOM composition after land-use change), and objective 3 (management practices and their impacts on SOC decomposition and sequestration). 


\subsection{Material and Methods}

\subsubsection{STUDY AREA}

The studies for this dissertation were conducted in the lowlands of Jambi Province on Sumatra Island, Indonesia. The region has a tropical humid climate with a dry season from April to September. The average annual rainfall is $2235 \mathrm{~mm}$ and the average annual temperature of $27.6{ }^{\circ} \mathrm{C}$ (Drescher et al., 2016). The natural vegetation in the lowlands of Jambi Province is dipterocarp rainforest (Laumonier, 1997). Nowadays, the region is dominated by large rubber (Hevea brasiliensis) and oil palm (Elaeis guineensis) plantations, which have replaced the natural forest.

All research sites in forest and on rubber and oil palm plantations were provided and maintained by the German Research Foundation Project CRC 990: Ecological and Socioeconomic Functions of Tropical Lowland Rainforest Transformation Systems (Sumatra, Indonesia). 24 study plots $(50 \times 50 \mathrm{~m})$ were selected, representing riparian and well-drained areas and typical natural and agricultural systems of the region (Figure 1.2-1). Four degraded primary rainforest sites (Margono et al., 2014) in riparian and four degraded primary rainforest sites in well-drained areas served as reference sites. Research sites were four rubber and four oil palm plantations in riparian areas and four rubber and four oil palm plantations in well-drained areas, which varied between 8-18 years (rubber) and 1016 years (oil palm) in stand age (Drescher et al., 2016). Plantations in both landscape types were managed by smallholder farmers. In the riparian areas, soils were classified as Gleysols, Stagnosols and stagnic Acrisols (Study 2). In well-drained areas soils were described as Acrisols with a sandy loam texture (Guillaume et al., 2015). Effects of land-use change were assessed by comparing forests sites with rubber and oil palm monocultures (Study 2 and 3). Effects of landscape differences were assessed by comparing riparian and well-drained areas (Study 2). 


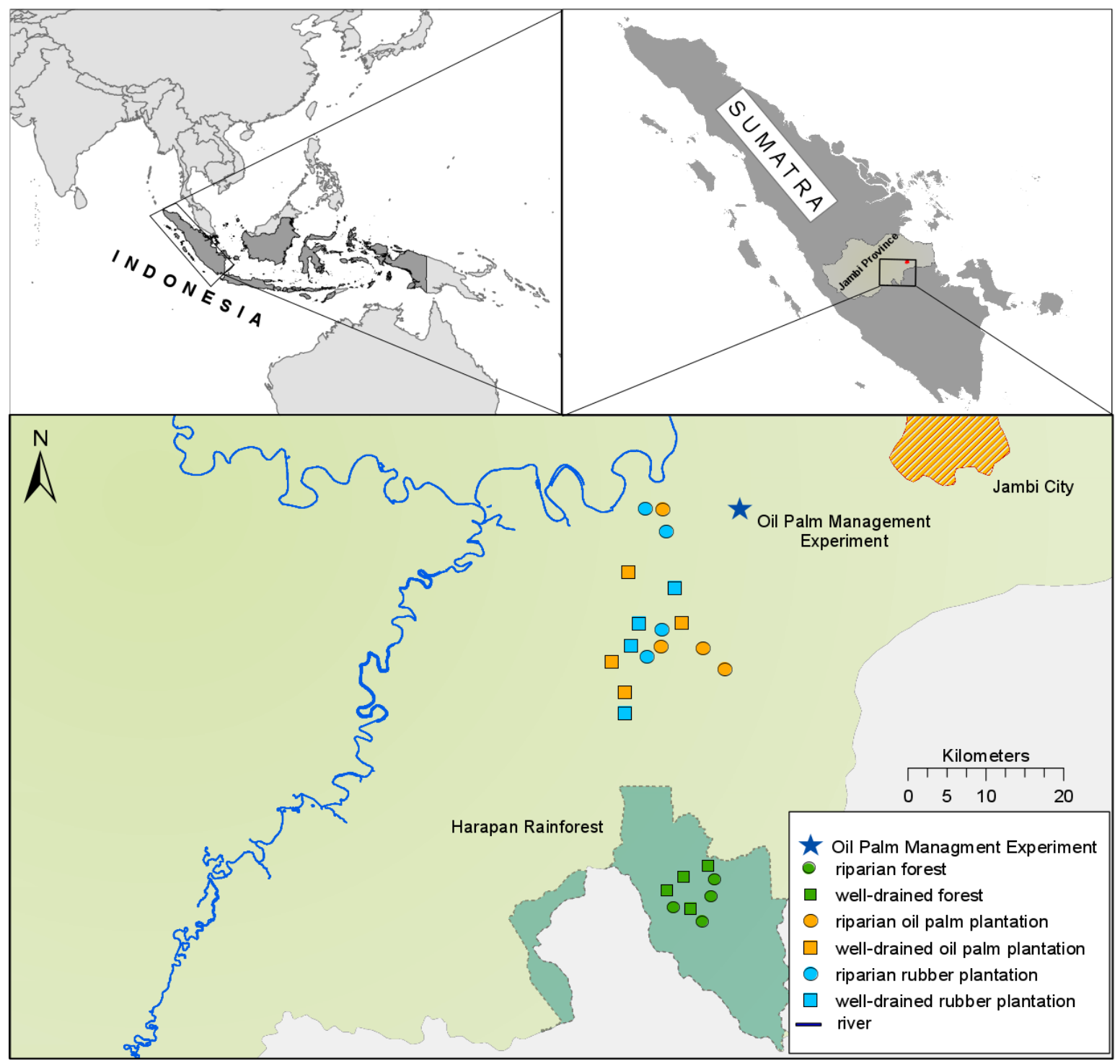

Figure 1.2-1: Research sites in Jambi Province. Map was produced based upon the datasets of the EFForTS Project database and service.arcgis.com, using ESRI ArcGIS software (version 10.7.1; www.esri.com).

An additional well-drained oil palm plantation was selected to study management effects on SOC decomposition in oil palm plantations (Study 4). This industrial oil palm plantation was owned and managed by the state company PTPN IV close to Jambi City $\left(1^{\circ} 43^{\prime} 8^{\prime \prime} \mathrm{S}\right.$, $103^{\circ} 23^{\prime} 53^{\prime \prime}$ E). Part of the plantation is used for implemenatiom of the Oil Palm Management Experiment by the CRC 990 project. The experimental setup was designed to determine different management intensities and their impacts on biodiversity, soil and economic yields. Four $50 \times 50 \mathrm{~m}$ plots were selected with four different treatments (conventional $\mathrm{N}$ vs. reduced $\mathrm{N}$ fertilization and glyphosate vs. mechanical weed control). The soil of this study site was classified as an Acrisol (Darras et al., 2019). 


\subsubsection{RESEARCH APPROACHES}

\subsubsection{Space-for-time substitution approach to assess effects of land-use change on C stock}

Evaluating long-term SOC stock changes would be beyond the duration of conventional experiments and field studies. To overcome this problem, the space-for-time substitution approach was used, which allows to examine the effects of land-use change on SOC stock and SOM composition within a shorter time period (Faber et al., 2018; Pickett, 1989). The concept is to identify spatial gradients which represent two or more contrasting conditions ("space") and symbolize past and current conditions ("time") (Pickett, 1989). Several studies have used this approach to investigate long-term consequences of natural vegetation modification by humans (de Blécourt et al., 2013; Faber et al., 2018; Powers, 2004; Rahman et al., 2018; Straaten et al., 2015). To do this, we compared sites in a degraded primary forest (Margono et al., 2014) with rubber and oil palm plantations that were spatially as close as possible maintain similar environmental conditions, such as the soil type.

\subsubsection{Stable isotopes application to assess the $C$ decomposition status}

The application of the stable isotope ${ }^{13} \mathrm{C}$ from soil depth profiles allows to evaluate the decomposition state of SOM (Alewell et al., 2011; Guillaume et al., 2015; Krüger et al., 2014). $\delta^{13} \mathrm{C}$ values were used as a measure of ${ }^{13} \mathrm{C}$ abundance relatively to ${ }^{12} \mathrm{C}$ abundance and calculated as the deviation from the standard reference for ${ }^{13} \mathrm{C}:{ }^{12} \mathrm{C}$ ratio of the standard reference (Vienna PDB). In mineral soils, $\delta^{13} \mathrm{C}$ values increase with soil depth and soil age, because aerobic decomposition processes dominate and lead to ${ }^{13} \mathrm{C}$ enrichment (Andreeva et al., 2013; de Junet et al., 2005; Zang et al., 2018). However, in riparian areas, soils are subject to wet-dry cycles and undergo alternating aerobic and anaerobic degradation, which alters the ${ }^{13} \mathrm{C}$ fractionation with increasing depth. Decomposition under anoxic conditions might be delayed and leads to slower ${ }^{13} \mathrm{C}$ fractionation, displayed by little changing $\delta^{13} \mathrm{C}$ values and therefore a uniform depth profile. If shifts to lighter $\delta^{13} \mathrm{C}$ values are detected, this will hint to an enrichment of recalcitrant organic substances during anaerobic decomposition which are depleted in ${ }^{13} \mathrm{C}$ (Alewell et al., 2011; Drollinger et al., 2019). 
Based on the findings of Guillaume et al. (2015), who assumed $\delta^{13} \mathrm{C}$ depth profiles to be a appropriate tool for assessing erosion dynamics due to land-use change, we developed a conceptual understanding of SOM decomposition under riparian conditions. In addition, physical mixing and deposition of fresh material with different degrees of degradation affect the ${ }^{13} \mathrm{C}$ signature which can also lead to abrupt $\delta^{13} \mathrm{C}$ changes in the depth profile (de Junet et al., 2005; Kelleway et al., 2017). Therefore, riparian properties may lead to unique C storage mechanisms, which are expressed as specific dynamics in the $\delta^{13} C$ proxy.

\subsubsection{Free lipids as biomarkers to analyze past land uses and SOM composition}

To estimate whether SOM under agricultural cultivation originates from forest or already from plantations and to assess the SOM composition after land-use change, a multiple biomarker approach was chosen to trace the former pool of SOM found in plantations' soils. A "Biomarker is an organic compound with a defined structure indicative of its producer" (Amelung et al., 2008, p. 156). Biomarkers allows to distinguish between different possible sources of SOM, such as plants, fungi, bacteria, animals, fire and anthropogenic sources (Amelung et al., 2008) and are common tools to reconstruct past land uses and/or to understand pathways of SOC formation. In this dissertation, the focus was on biomarkers for plant-derived C, because 1) the main source of SOC is plant-derived organic matter (Crow et al., 2009; Kögel-Knabner, 2002) and 2) it was the aim to determine the extend to which past forest vegetation still contributes to the SOC pool in topsoil after transformation in agricultural plantations. Suitable compounds from epicuticular waxes produced by vascular plants are free lipids. One typical lipid class for epicuticular waxes are n-alkanes homologues with 24-36 carbon atoms and a strong odd-over-even predominance (OEP), as a result of the universal polyketide (acetate, malonate) biosynthetic pathway. Because of their long $C$ chains, they are environmentally persistent compounds and are used as molecular proxies in paleoclimatology (Eglinton and Eglinton, 2008). N-alkanes precursors are fatty acids, hydroxy fatty acids, alcohols and ketones. To trace the SOC source in plantation soils and to better understand the pathways of SOC formation we combined alkanes, fatty acids, hydroxy, alcohols and ketones to a muti-biomarker approach. For this, we compared soil, litter and root samples from forest, rubber and oil plantations and determined the free lipid fingerprint change after conversion. For the vegetation 
reconstruction of the paleo-horizon of one of the forest profiles forest litter and roots samples were used as references.

\subsubsection{Priming experiment to assess SOC decomposition under different management practices}

Based on the oil palm management field experiment conducted by the CRC 990, we performed a laboratory experiment under controlled conditions to gain a mechanistic understanding of SOC decomposition under four different management practices. The four management practices were: 1) a conventional fertilization level + herbicide application, 2) conventional fertilization level + mechanical weeding, 3) a reduced fertilization level + herbicide and 4) a reduced fertilization level + mechanical weeding. Fertilizer and herbicide are applied to the WC. IR also receive herbicide for weed control, but no fertilizer (details on fertilization levels see Study 4, 2.4.3).

Soil from WC and IR was incubated for 33 days and was treated accordingly to field experiment conditions with two different levels of NPK fertilizer and glyphosate (Study 4, 2.4.3.3). In the incubation experiment organic input is simulated by adding glucose, as it is the most often released sugar from rhizodepositis (Derrien et al., 2007). To distinguish between nutrient release and SOC decompositon from the added substsance and from $\mathrm{SOM}$, the glucose was ${ }^{14} \mathrm{C}$-labelled. We triggered so-called priming effects (PE), a short-term change in SOM turnover. The PE is a response after glucose amendement and therefore a comparison with a control group without easily-available $C$ amendement is needed to measure and calculate PE (more details Study 4, 2.4.3.5). The concept of priming experiments allows us to develop a mechanistic understanding of processes of nutrient release, SOM turnover and $\mathrm{C}$ stabilization under agricultural use.

\subsubsection{Field sampling}

In total two sample sets were collected between July and September 2016 in Jambi Province.

Sample set one $-C$ stock, stable isotopes, free lipids in riparian areas: The soil was sampled from four forest, four rubber and four oil palm plantation sites. The samples were collected by different depth intervals from the soil profile. The depth intervals were $0-5 \mathrm{~cm}, 5-10 \mathrm{~cm}, 10-$ $20 \mathrm{~cm}, 20-30 \mathrm{~cm}, 30-50 \mathrm{~cm}, 50-70 \mathrm{~cm}, 70-90 \mathrm{~cm}$ and $90-100 \mathrm{~cm}$. Accordingly to these depth intervals, soil rings were inserted horizontally for bulk density determination. Bulk density 
data consisted of five replicates per site and soil depth interval. Based on this soil material C stock calculation, stable isotopes and free lipid determinations were performed. Additionally, litter from all sites was sampled. Roots from $10 \mathrm{~cm}$ soil depth in all three landuse types were sampled by another research group and later used as free lipid reference material.

Soil profiles in well-drained areas were 50-60 cm deep and already described and sampled horizon-based in 2012 during a previous doctoral thesis (Guillaume, 2015).

Sample set two-SOC decomposition experiment: The soil was sampled from a state-owned and managed industrial oil palm plantation (PTPN VI). To cover the representative areas of the plantation composite samples were collected in the IR between the palm rows and the WC, 1-2 $\mathrm{m}$ around the palm stem. Samples were collected from 0-10 and 10-30 cm soil depth and later mixed to gain one sample, covering the first $30 \mathrm{~cm}$ of soil depth, for the soil incubation experiment. These locations were always sampled under the four different management practices (Study 4, Figure 2.4-1). Additionally, bulk density samples from the topsoil were collected to derive soil density needed in incubation jars for the SOM decomposition experiment.

\subsubsection{Analytical methods}

\section{Carbon (C) and Nitrogen (N) content (\%)}

Sample set one was dried for two weeks at $40^{\circ} \mathrm{C}$, sieved to $2 \mathrm{~mm}$ and ground. Sample aliquots were weighed into tin capsules for organic carbon (OC) and total $\mathrm{N}$ analysis. Because inorganic C content was found neglectable on the research sites, total C corresponds to organic C. Measurement was performed by a Vario el cube (Elementar, Langenselbold, Germany) at the Georg-August-University Göttingen.

\section{Stable isotope analysis}

Dried soil sample aliquots of set one (two weeks at $40^{\circ} \mathrm{C}$ ) were sieved to $2 \mathrm{~mm}$, ground and weighed into tin capsules. For determining the natural abundance of ${ }^{13} \mathrm{C}$ isotopes, the ratio of ${ }^{13} \mathrm{C}:{ }^{12} \mathrm{C}$ was examined by using an Elemental Analyser (NA1110, CE-Instruments, Rodano, Milano, Italy) coupled via a ConFlow III to an isotope ratio mass spectrometer (IRMS) (Delta Plus, Finnigan MAT, Bremen, Germany). ${ }^{13} \mathrm{C}$ abundance is expressed in the 
$\delta^{13} \mathrm{C}$ notation in per mille (\%o) which describes the ratio of ${ }^{13} \mathrm{C}:{ }^{12} \mathrm{C}$ abundance relatively to the international PDB limestone standard (Craig, 1953).

\section{$\mathrm{CO}_{2}$ measurements: natural abundance and ${ }^{14} \mathrm{C}$ labelled samples}

$\mathrm{CO}_{2}$ from incubated soil of the sample set two was sampled by trapping it in $\mathrm{NaOH}$ solution. After collection, the samples were stored at $-20^{\circ} \mathrm{C}$. The amount of $\mathrm{C}$ in $\mathrm{NaOH}$ was measured by a 2100 TOC/TIC analyzer (Analytik Jena, Jena, Germany) in an aliquot of 0.2 $\mathrm{ml}$ with a 1:15 dilution. ${ }^{14} \mathrm{C}$ activity in ${ }^{14} \mathrm{C}$-glucose labelled samples was measured by a liquid scintillation counter (300 SL Hidex, Turku, Finland). For this, $0.3 \mathrm{ml}$ of the $\mathrm{NaOH}$ solution was mixed with $2 \mathrm{ml}$ of the ROTISZINT LSC-universal scintillation cocktail (Carl Roth, Karlsruhe, Germany).

\section{Quantification of microbial abundance}

To extract the total genomic DNA from incubated soil the FastDNA Spin Kit for soil (MP Biomedicals, Santa Ana, USA) was used, following the manufacturer's instructions. The extracted DNA was quantified with a NP80 NanoPhotometer (Implen, Munich, Germany). Carbon in microbial biomass was estimated by multiplying the dsDNA with the correction factor 5.0 (Anderson and Martens, 2013).

\section{Free lipid extraction}

The extraction of free lipids was performed based on the extraction methods developed by Birk et al. (2012) and was combined with integrating elements suggested by Wiesenberg et al. (2004). $10 \mathrm{~g}$ of dried and ground soil and $3 \mathrm{~g}$ of dried roots and litter were weighed in for free lipid extraction by a Soxhlet apparatus. Extracted free lipids, were spiked with internal standards (hexatriacontane for n-alkanes, 2-pentadecanone for ketones, 1nonadecanol for n-alkanols, nervonic acid for fatty acids, 12-OH stearic acid for hydroxy fatty acids). The extracts were then separated into the neutral and acid fraction. The neutral fraction was purified and separated into n-alkane and ketons (together with n-alcohols and aromatic) fractions by solid phase extraction (SPE) with high purity silica gel. The acid fraction was methylated to fatty acid methyl esters (FAMEs), purified and separated into the fatty acid and hydroxy fatty acid fraction. Subsequently, the ketone and hydroxy fatty acid fractions were acetylated. The samples were then measured by gas chromatography on an Agilent 7890A GC, which was coupled to an Agilent 7000A triple quadrupole mass spectrometer (Agilent, Waldbronn, Germany). External standards for all lipid fractions 
were methylated and/or acetylated according to the corresponding samples and used for later substance quantification.

\section{Soil physical analyses}

Bulk Density $\left(\mathrm{g} \mathrm{cm}^{-3}\right)$ was calculated from oven dried (weighed and dried at $105^{\circ} \mathrm{C}$ until constant weight) undisturbed soil rings $\left(100 \mathrm{~cm}^{3}\right)$ collected from the respective soil depth intervals. Soil texture was determined by applying an adapted method based on Atterberg for the complete recovery of individual grain fractions (1912). Before the analysis, humus and iron oxides were removed by using sodium dithionite.

\subsection{Results and Discussion}

This chapter is divided into the following sections: First, I present an overview of the main results of the single studies (Table 1.3-1). Second, the findings of the individual studies are presented and discussed with a special focus on the objectives of this thesis and with the aim to combine their results and conclusions.

Table 1.3-1: Overview of studies included in this thesis with main objectives, results, and conclusions

\begin{tabular}{|c|c|c|}
\hline Study & Objectives & Main results/conclusions \\
\hline $\begin{array}{l}\text { Study 1: Flooding and } \\
\text { land-use change in Jambi } \\
\text { Province, Sumatra: } \\
\text { integrating local } \\
\text { knowledge and scientific } \\
\text { enquiry }\end{array}$ & 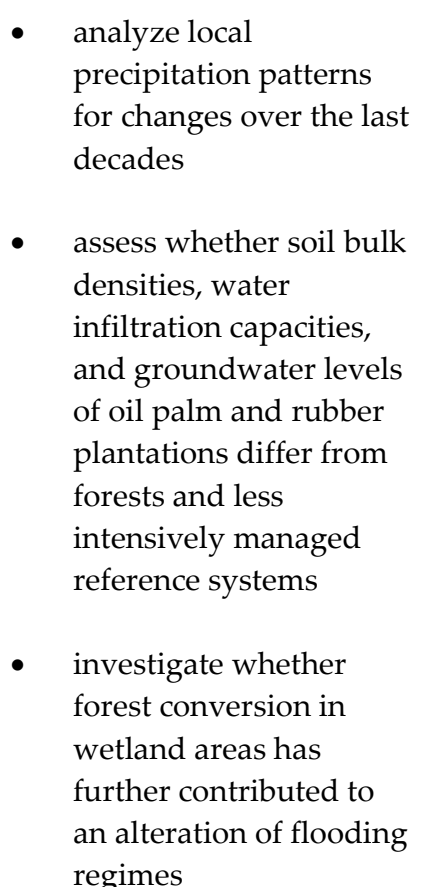 & 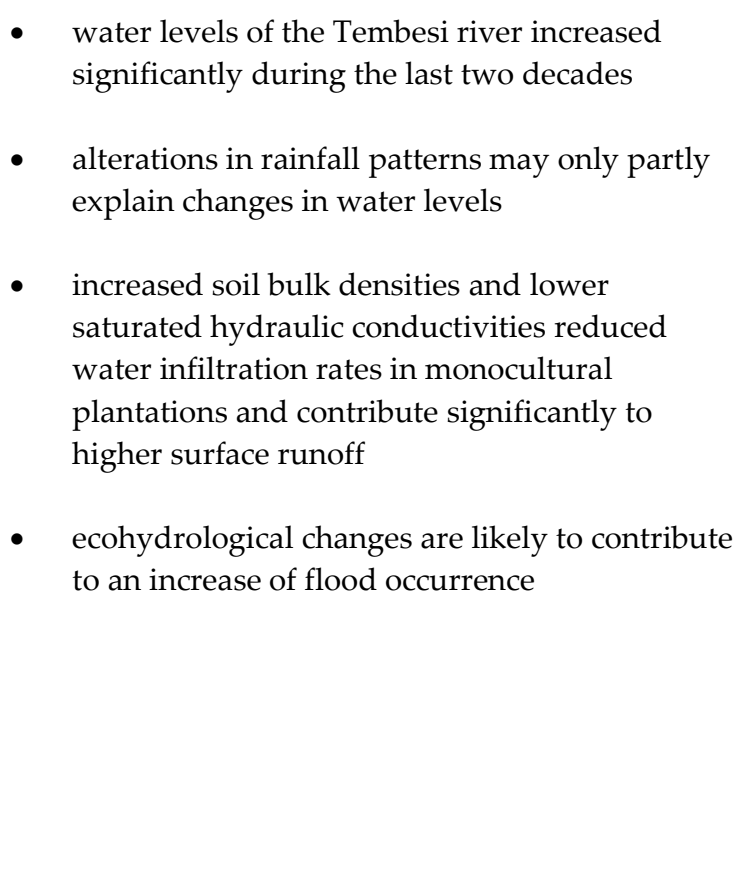 \\
\hline
\end{tabular}

Study 2: Riparian wetland properties counter the effect of land use change on soil carbon stocks after
- quantify SOC losses in riparian areas after landuse change from forest to
- $\quad \delta^{13} \mathrm{C}$ depth profiles are highly heterogenous in riparian areas 


\begin{tabular}{lll}
\hline $\begin{array}{l}\text { rainforest conversion to } \\
\text { plantations }\end{array}$ & $\begin{array}{l}\text { oil palm and rubber } \\
\text { plantations }\end{array}$ & $\begin{array}{l}\text { specific geomorphic conditions in riparian areas } \\
\text { counter land-use effects through two dominant } \\
\text { processes: }\end{array}$ \\
$\begin{array}{l}\text { determine whether land- } \\
\text { use change has } \\
\text { comparable impacts on } \\
\text { riparian and well-drained } \\
\text { areas } \\
\text { mineralization under alternating oxic and anoxic } \\
\text { conditions and } \\
\text { input and accumulation of allochthonous organic } \\
\text { materials with various decomposition degree }\end{array}$ \\
$\begin{array}{ll}\text { develop a conceptional } \\
\text { understanding of C } \\
\text { sequestration and storage } \\
\text { in riparian areas to } \\
\text { disentangle SOM } \\
\text { decomposition from } \\
\text { erosion losses and } \\
\text { deposition }\end{array}$ \\
\hline
\end{tabular}

Study 3: Reconstructing the sources of soil organic matter after land-use change in Indonesia using a multiple biomarker approach
- $\quad$ reveal contribtion of past vegetation to the current SOC pool

- determine changes in SOM composition in rubber and oil palm plantations

combination of multiple biomarkers reveals that $\mathrm{C}$ input from past forest vegetation still substiantially contributes to the plantations' SOC pool

the fatty acid i15:0 indicates microbial necromass as an important $C$ source

odd-over-even predominance and average chain length as additional indicators hint at a dominance of plant-orginating $\mathrm{C}$

the change of SOM composition of n-fatty acids 27:0 and 29:0 highlights the importance of microbial biomass by transforming OM during decomposition

higher NPK level caused microbial activation

Study 4: Intensive management practices in oil palm plantations and the impact to soil organic matter (SOM) decomposition
- gain a mechanistic understanding about the impact of common agricultural management practices on SOC decomposition in oil palm plantations

- determine whether accelerated SOC decomposition is caused by $\mathrm{N}$ fertilization

- examine whether herbicide application increases soil organic carbon (SOC) sequestration, by hampering soil microbial activity via the deactivation of the shikimate pathway thus leading to decreased microbial respiration higher NPK level destabilized SOC by priming, resulting in increased $\mathrm{CO}_{2}$ efflux

Glyphosate intensified microbial activity

lower NPK levels and no glyphosate application reduced SOC decomposition i.e., less negative priming effect 


\subsubsection{LAND-USE CHANGE AND RIPARIAN EFFECTS ON SOIL PHYSICAL PROPERTIES}

Changing groundwater tables (GWT) in riparian areas and soil compaction as a consequence of forest conversion can strongly influence soil properties. Groundwater tables (GWT) between 2017 and 2019 in riparian areas were higher in forest sites $(55 \mathrm{~cm}, \pm$ $27 \mathrm{~cm}$ below the soil surface) than in rubber $(103 \mathrm{~cm}, \pm 39 \mathrm{~cm})$ or oil palm $(124 \mathrm{~cm}, \pm 50 \mathrm{~cm})$ plantations. GWT in plantations, however, had higher amplitudes compared to GWT in the forest. Amplitudes ranged between $150 \mathrm{~cm}$ in plantations and a maximum of $50 \mathrm{~cm}$ in forests within a few hours after rainfall. Higher amplitudes of GWT in oil palm and rubber plantations compared to forests hint at a reduced flood control due to retarded water infiltration and lower saturated hydraulic conductivity $\left(\mathrm{K}_{\mathrm{fs}}\right)$ after land-use change (Study 1). Soil compaction, due to heavy machinery used for deforestation and later harvest activities, can significantly reduce the saturated hydraulic conductivities (Pachepsky and Park, 2015, Hassler et al., 2011). In line with this, bulk densities increased after land-use change, with 1.3-fold higher bulk densities in rubber and oil palm plantations' topsoils than in forest topsoils (Study 1). Bulk densities in the subsoil $(30-50 \mathrm{~cm})$ of plantations and forests, however, were similar and did not show a compaction after land-use change. This corresponds with a previous study in this region (de Blécourt et al., 2013) and agrees with the assumption that the first $30 \mathrm{~cm}$ of soil are particularly affected by land-use changes (e.g., Chiti et al., 2014; Don et al., 2011; Guillaume et al., 2015). The soil compaction in the topsoil, however, is sufficient to affect long term soil hydraulic properties such as hydraulic conductivity, permeability and porosity, when topsoil bulk densities reach a value of around $1.36 \mathrm{~g} \mathrm{~cm}^{3}$ (Pachepsky and Park, 2015). More than 30\% of the assessed oil palm and rubber plantations exceed this threshold (Study 1). K $\mathrm{fs}$ measurements in an oil palm monoculture plantation $\left(6.5 \pm 1.7 \mathrm{~cm} \mathrm{~h}^{-1}, \mathrm{n}=4\right)$ were three times lower than in an oil palm plantation, which was enriched with trees (biodiversity enrichment experiment: $22.6 \pm 2.6$ $\mathrm{cm} \mathrm{h}^{-1}, \mathrm{n}=33$ ), implying high surface runoff in monocultures and enhanced water permeability under more diverse and natural conditions (Study 1). In combination with higher amplitudes of GWT in plantations than in forests, we conclude that rubber and oil palm plantations are more prone to flooding after rainfall events than forests (Study 1). 


\subsubsection{LAND-USE CHANGE AND RIPARIAN EFFECTS ON SOC STOCKS AND DECOMPOSITION}

These changes in soil physical properties are partly the result of forest conversion to plantations, but also strongly associated with riparian-specific characteristics such as changing water tables, fluctuating water saturation and anoxic conditions, and sedimentation. Riparian properties have strong impacts on soil C stocks after land-use change.

SOC stocks are known to be strongly reduced after forest conversion to plantations (Don et al., 2011; Guillaume et al., 2015; Rahman et al., 2018). In riparian areas, however, riparianspecific properties counteract the effect of land-use change on SOC stocks (Study 2). Average soil $\mathrm{C}$ stock losses from the upper $30 \mathrm{~cm}$ were about $14 \%$ and $4 \%$ following conversion of riparian forest to rubber and oil palm plantations, respectively, indicating a high resistance of sequestered $C$ to mineralization. In contrast, well-drained sites in the same region lost $24 \%$ SOC after conversion to rubber and $22 \%$ after conversion to oil palm plantations (Study 2). This contradicts the hypothesis $1 \mathrm{~b}$ that SOC losses in riparian areas are higher than in well-drained areas.

Lower SOC losses after conversion in riparian areas are likely the results of two main factors: first, alternating oxic and anoxic conditions as a result of high GWTs, high amplitudes and periodical flooding retard and slow down SOC decomposition (Alewell et al., 2011; Drollinger et al., 2019) and second, increased flood frequency and intensity, due to high bulk densities and high GWT as well as low water infiltration (Bruijnzeel, 2004), can lead to increased surface runoff and to substantial erosion and deposition events. As a consequence of this material transport, organic matter can be moved in and out of the riparian system (Study 2). Abrupt changes in soil particle size and buried C-rich layers in the riparian areas (Figure 1.1-2) support that soil material transport in form of sedimentation and erosion takes place (Study 2).

Depth profiles of natural ${ }^{13} \mathrm{C}$ abundances support that soil material transport, caused by periodical flooding, plays a role in riparian areas. Single $\delta^{13} \mathrm{C}$ depth profiles in the plantations show a strong erratic and irregular pattern with increasing soil depth (Appendix, A 2.2-4), which hints at erosion and deposition events, bringing organic matter from various sources to the plantations (Davies et al., 2012). This shows that riparian areas 
are highly variable landscapes and that statements about sedimentation can be made primarily at the catchment level. Hence, it should be considered that sedimentation can play a distinct role in SOC input and loss but to better disentangle the influence of sedimentation processes and land-use change another research approach should be employed, i.e., collecting sediment loads in sediment traps and mesh bags or by installing erosion pins.

The elucidation of SOC decomposition processes is based on the assumption that $\mathrm{C}$ content and $\delta^{13} \mathrm{C}$ values in the plantations' subsoils were similar to the forest subsoil, prior to conversion and that after erosional loss of the upper soil layer, subsoil C content and $\delta^{13} \mathrm{C}$ values were vertically shifted towards the surface (Guillaume et al., 2015). To apply and verify this theory for soils in riparian areas, we compared $\delta^{13} \mathrm{C}$ patterns down to $1 \mathrm{~m}$ soil depth between forests, rubber and oil palm plantations in riparian and in well-drained areas (Figure 1.3-1).

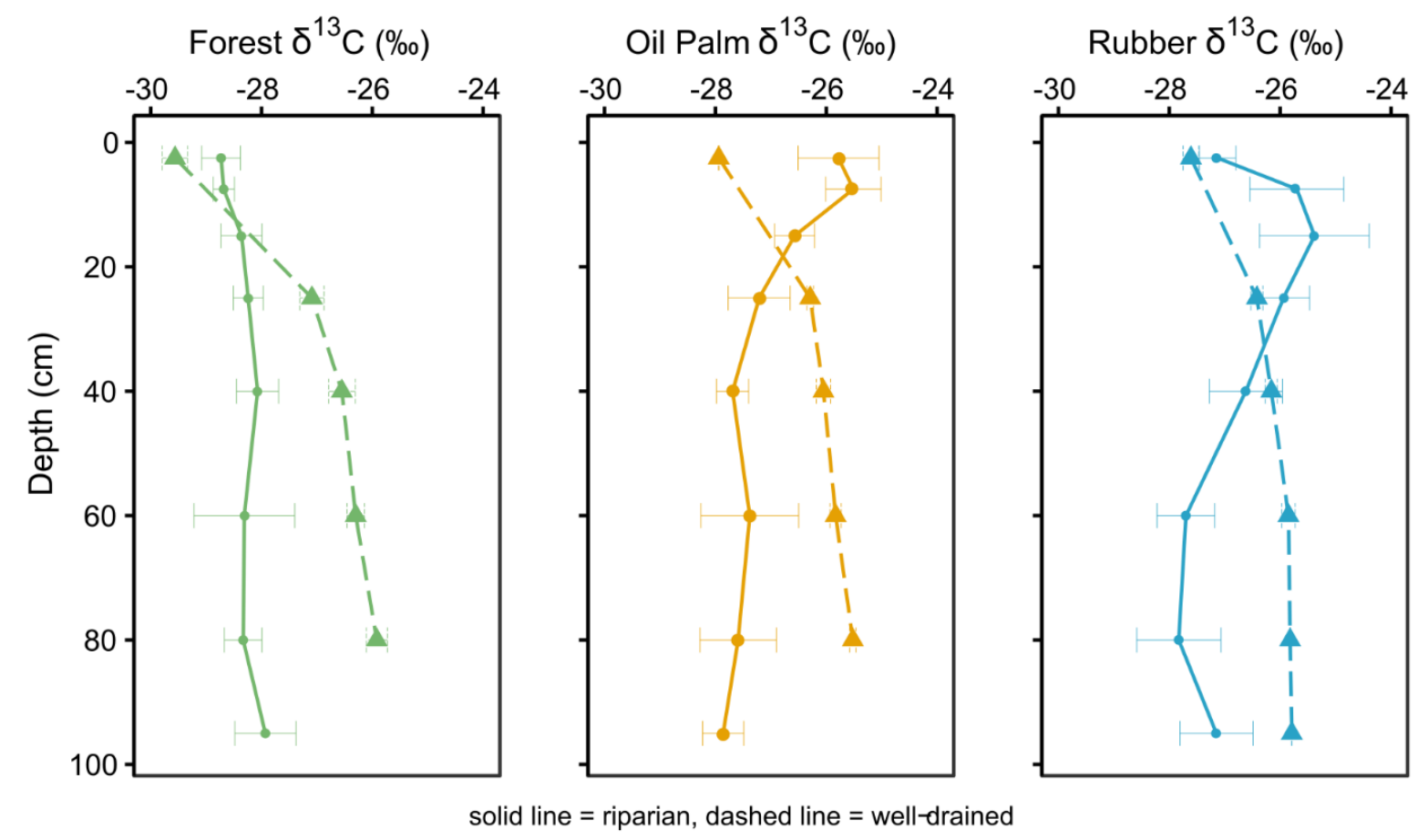

Figure 1.3-1: $\delta^{13} \mathrm{C}$ depth profiles in riparian (solid lines) and well-drained areas (dashed lines). $\delta^{13} \mathrm{C}$ values at fixed depth represent means (in riparian forest $n=3$, well-drained forest and in all plantations $n=4$ ). Error bars indicate the standard error of the mean.

Riparian forests and plantations differed strongly in their isotopic signatures in the topand the subsoil. The $\delta^{13} \mathrm{C}$ values in the riparian forest topsoil's were on average $2.5 \%$ ower than in the plantations, indicating that more enriched $C$ is shifted to the soil surface after 
conversion, induced by soil material transportation as Guillaume et al. (2015) suggested and what can be recognized when comparing the topsoils of well-drained forest and plantations (Figure 1.3-1). Down the soil profile riparian forests had more negative $\delta^{13} \mathrm{C}$ values, varying between $-29.3 \%$ and $-28.1 \%$ with a more uniform depth profile than riparian plantations. In riparian rubber and oil palm plantations, however, turning points were found at 25 and $7.5 \mathrm{~cm}$ depth, respectively, where the $\delta^{13} \mathrm{C}$ pattern shifted to lower values.

Riparian forest profiles showed a uniform $\delta^{13} \mathrm{C}$ pattern down to $1 \mathrm{~m}$, which is common under constant water-saturated conditions and typical when anaerobic decomposition processes dominate, respectively, when ${ }^{13} \mathrm{C}$ fractionation is slowed down (Alewell et al., 2011; Drollinger et al., 2019). Further, the turning points in $\delta^{13} \mathrm{C}$ patterns of rubber and oil palm plantations indicate a change from aerobic to anaerobic decomposition where more recalcitrant organic substances could be enriched (Alewell et al., 2011). ${ }^{13} \mathrm{C}$-depleted substances that decompose slowly such as lignin and/or lipids, are likely preserved under the anoxic conditions in the deeper soil layers. However, in plantations subsoils, slightly fluctuating $\delta^{13} \mathrm{C}$ patterns between higher and lower $\delta^{13} \mathrm{C}$ values were stated. These more heterogeneous patterns support the interpretation of alternating dry-wet cycles (Broder et al., 2012; Loisel et al., 2009) due to changing GWT (Study 1) and periodical flooding leading to alternating aerobic and anaerobic SOC decomposition.

In contrast to the subsoils, the topsoils in both riparian plantation types are likely dominated by aerobic decomposition, as indicated by ${ }^{13} \mathrm{C}$ enrichment in the top 10 and 20 $\mathrm{cm}$, respectively. For the topsoils, we assume an effect of land-use change, indicated by $2.5 \%$ higher $\delta^{13} \mathrm{C}$ values in the topsoils of plantations where the topsoil has been welldrained during conversion than in the forest. These findings agree with Guillaume et al. (2015) who found that more enriched C is shifted to the soil surface after conversion, caused by erosion after land-use change. This effect can only be stated for the topsoil, and is in line with findings from Don et al. (2011) and Chiti et al. (2014) that land-use change primarily affects the upper $30-40 \mathrm{~cm}$. The $\delta^{13} \mathrm{C}$ values in riparian forest and plantations' subsoils, on the contrary, should be similar as was clearly shown for well-drained areas (Guillaume et al., 2015), but which does not hold true in the riparian areas. Hence, we concluded, that 
alternating oxic and anoxic conditions strongly drive the formation of the $\delta^{13} \mathrm{C}$ depth profiles in riparian plantations (Study 2).

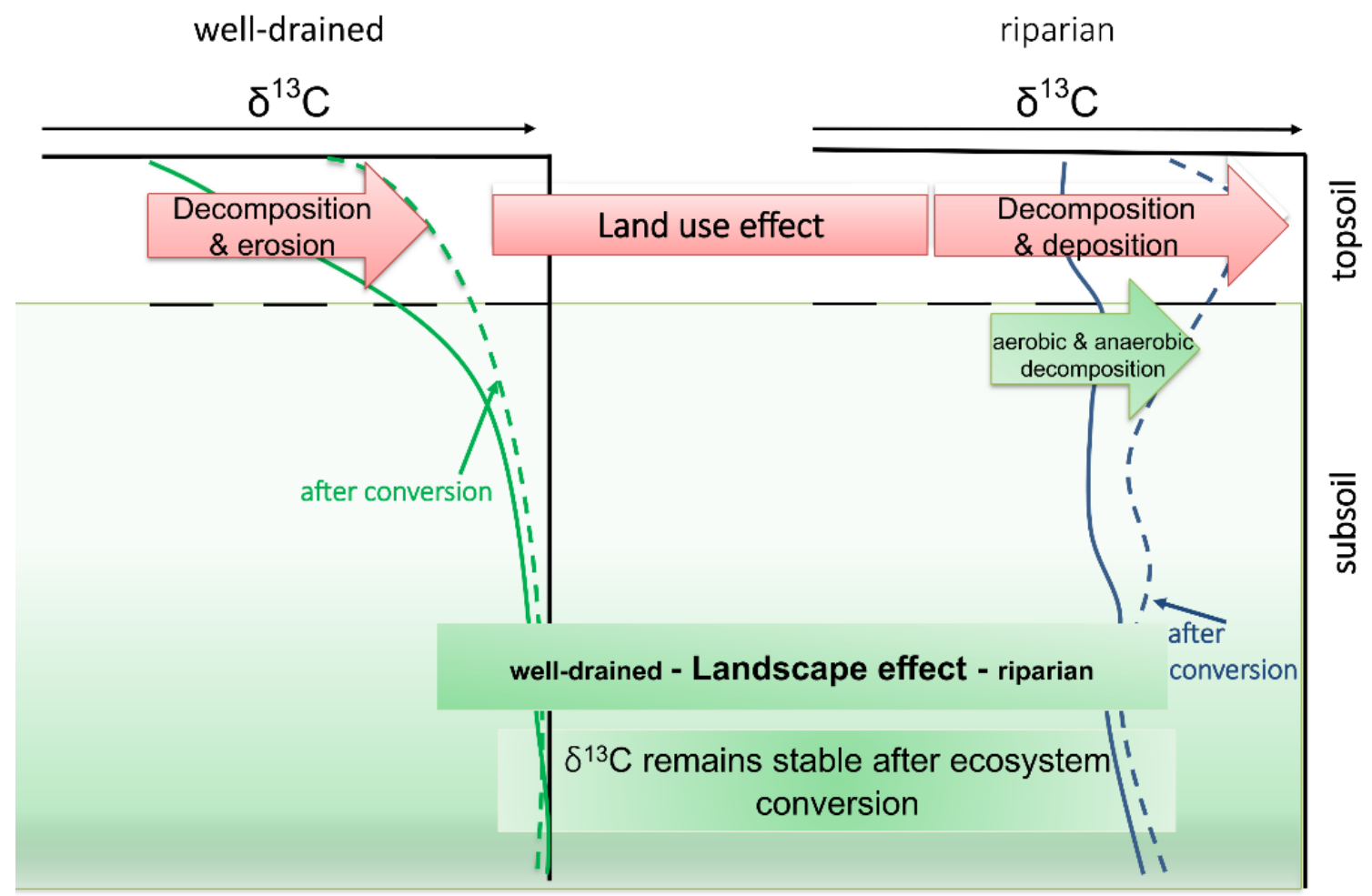

Figure 1.3-2: Impact of riparian forest conversion in combination with specific ecosystem characteristics on $\delta^{13} \mathrm{C}$ distribution on soil depth, separated in decomposition and erosion effects in well-drained areas (left) and decomposition and deposition as well as alternating oxic and anoxic conditions in riparian areas (right).

Based on the results it can be stated that riparian-specific processes counter the expected land-use change effect and dominate the fate of SOC storage in riparian soils due to the following two porcesses: first, alternating oxic and anoxic conditions and second, input and accumulation of allochthonous organic materials with various decomposition degree (Figure 1.3-2). The preservation of $\mathrm{C}$ due to oxygen-limited mineralization and sedimentation as a pathway of $\mathrm{C}$ input in plantations, may be the reasons for a smaller impact of land-use change on SOC stocks than expected. The conclusion that riparian areas are more resilient towards SOC losses seems to be obvious, however, one should not forget that riparian areas, especially if drained similar to peatlands, have a high C loss potential, when considering high subsoil C amounts in buried C-rich layers.

\subsubsection{RECONSTRUCTING SOC SOURCES IN BURIED SOIL LAYERS}

Buried soil layers are found in forests as well as plantation soils (Figure 1.1-2) and represent a characteristic feature of soils in riparian areas. They are often enriched in C (e.g., SOC 
content of $8 \%$ at a depth from $70-100 \mathrm{~cm}$ ). To identify the SOC source of the buried layer in the riparian forest (Figure 1.1-2), n-alkanes were used as biomarkers for grass and trees. There was clear evidence that the buried layer from the forest originates from grass and/or herbs and not from forest tree vegetation, because of the clear dominance of $\mathrm{C}_{31-}$ and $\mathrm{C}_{33-}$ alkanes over $C_{27}$ and $C_{29}$, which are assigned to grass and herb origin (Zech et al., 2009). This dominance is visible in the n-alkane distribution of the buried soil layer. In upper layers $C_{31}$ and $C_{33}$ also have a dominance over $C_{27}$ and $C_{29}$, which is less pronounced compared to the buried layer. Buried layers are mostly a result of sedimentation processes (Shakhmatova and Korsunov, 2008; Zech et al., 2012), underlining the conclusion from Study 2, that sedimentation as a landscape-specific process in riparian areas affects SOC stocks. Further, the odd-over-even predominance (OEP) of the buried layer in the forest was about a value of 9 and more similar to the topsoil value of 7.5 than to the value of 3.5 in the 40-60 cm subsoil layer. An OEP > 5 displays less degradation and is attributed to fresh undegraded plant leaf waxes (Zech et al., 2012). Therefore, it was concluded that C is highly preserved in the buried layer, because of the gleysol characteristics, i.e., a high water table and a delayed decomposition due to anoxic conditions.

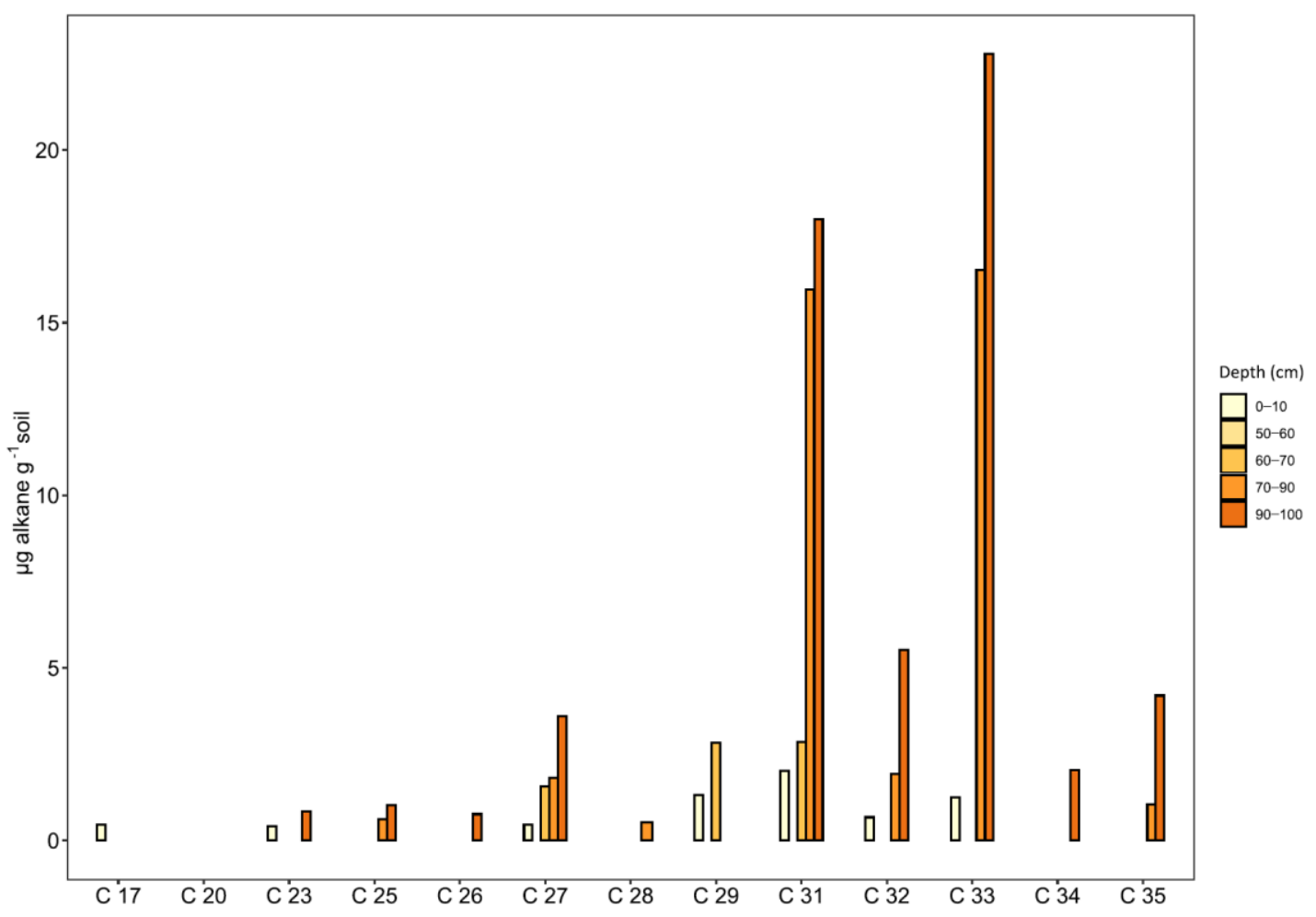

Figure 1.3-3: n-alkanes distribution in the forest profile with a buried layer. Clear dominance of $C_{31}$ and $C_{33}$ compared to $C_{27}$ and $C_{29}$ 


\subsubsection{CONTRIBUTION OF FOREST VEGETATION TO THE CURRENT SOC POOL AND CHANGE OF SOM COMPOSITION}

Given that riparian properties still influence SOC stocks and that C input is massively reduced after land-use change (Study 2), it was 1) the aim to determine the pools of origin of SOM constituents and 2) the change of SOM composition and its transformation after forest conversion to plantations (Study 3). Based on a non-metric multidimensional scaling (NMDS) (Study 3, Figure 2.3-1) and an indicator species analysis, specific substances of nalkanes, n-fatty acids and hydroxy fatty acids were identified (Table 1.3-2) that displayed the contribution of past vegetation to the SOC pool in rubber and oil palm plantations. Some of the indicator substances, however, are also commonly known as biomarkers for fungal and microbial origin, such as the fatty acids i15:0 and 18:2 $\omega 6,9$. Therefore, it was necessary to consider microbial transformation of lipids originally derived from plants and lipids originally derived from microbial biomass.

Table 1.3-2: Indicator Substances identified by Indicator Species Analysis (Study 3). Denominations in brackets represent the single or the group of C pool(s) or land-use type(s), which were separated from all other $C$ pools by the Indicator Species Analysis. No indicator substances were found in the alcohols/ketons fraction, which indicates that this fraction is not suitable for tracing $C$ sources.

\begin{tabular}{cccc}
\hline n-alkanes & n-fatty acids & hydroxy fatty and Di- acids & alcohols/ketones \\
\hline $\mathrm{C}_{25}$ & i15:0 & 16-OH-16:0 & - \\
(oil palm soil) & (oil palm / rubber soil) & (oil palm / rubber soil) & \\
$\mathrm{C}_{31}$ & $18: 2 \omega 6,9$ & 2-OH-24:0 & \\
(forest soil, rubber litter/soil) & (Forest litter/roots, Oil palm & (Oil Palm roots) \\
& soil, Rubber litter/ roots) & 16-Di-COOH-16:0 \\
& $24: 0$ & (Forest soil, Oil palm & (Forest soil, Oil palm soil, Rubber \\
& litter/roots, Rubber soil) & \\
& $27: 0$ & \\
& (Forest soil, Oil palm soil, & \\
& Rubber soil) & \\
& $28: 0$ & \\
& (Forest soil, Oil palm litter, \\
Rubber soil) & $29: 0$ \\
& (Forest soil, Oil palm litter/ \\
soil, Rubber soil)
\end{tabular}

Long-chain n-alkanes found as indicator substances were $\mathrm{C}_{25}$ and $\mathrm{C}_{31}$ (Table 1.3-2). They could not be detected in root samples (Figure 1.3-4 a/b), but in litter and soil samples, confirming their origin from leaf waxes (Eglinton and Hamilton, 1967). The relative abundance of $\mathrm{C}_{25}$ in oil palm topsoil tended to be higher as it was $9 \%$, and about 2.3-fold and 4-fold higher than in forest and rubber topsoil, respectively, hinting at relatively lower decomposition of organic material than under forest vegetation and rubber cultivation 
(Figure 1.3-4a). Since there were no significant differences between forest soils and plantation soils, we conclude a contribution of the forest SOC pool to the current SOC pool in plantations. $C_{31}$ made up a substantial proportion of rubber and oil palm litter $(28 \%$ and 17\%). Nguyen Tu et al. (2011), however, found litter contamination with long-chain nalkanes caused by microbial residues, which suggests that at least $\mathrm{C}_{31}$ might be partly derived from leaf colonizing bacteria and/or fungi. A strong argument for plant origin and against microbial transformation of $n$-alkanes however is that soil samples have a clear OEP in the range of $C_{27}$ to $C_{31}$ and long average chain lengths (ACL) (Study 3, Table 2.3-2). Nalkanes produced by many bacteria, on the contrary, show a distribution pattern ranging from $\mathrm{C}_{11}$ to $\mathrm{C}_{35}$ without any OEP and are dominated by shorter ACLs (Bush and McInerney, 2013; Ladygina et al., 2006). N-alkane patterns in soils in all three land-use types revealed a strong dominance of $C_{31}$ and $C_{33}$ over $C_{27}$ and $C_{29}$. Because $C_{31}$ and $C_{33}$ characterize grasses and herbs as C sources (Zech et al., 2012), it is assumed that litter-based C inputs to soils in all three land use types are dominated by herbs and grasses rather than trees and shrubs. Since a dense herb layer covers the soil in tropical forests, we consider higher $C_{31}$ and $C_{33}$ than $\mathrm{C}_{27}$ and $\mathrm{C}_{29}$ concentrations to be reasonable under forest. The same holds true for rubber plantations, that are often covered with grass. Oil palm plantations, however, often have bare soil and sometimes fragmented grass vegetation. This is probably reflected by a less pronounced dominance of $\mathrm{C}_{31}$ and $\mathrm{C}_{33}$ compared to $\mathrm{C}_{27}$ and $\mathrm{C}_{29}$ than under forest and rubber (Study 3, Figure 2.3-5). 


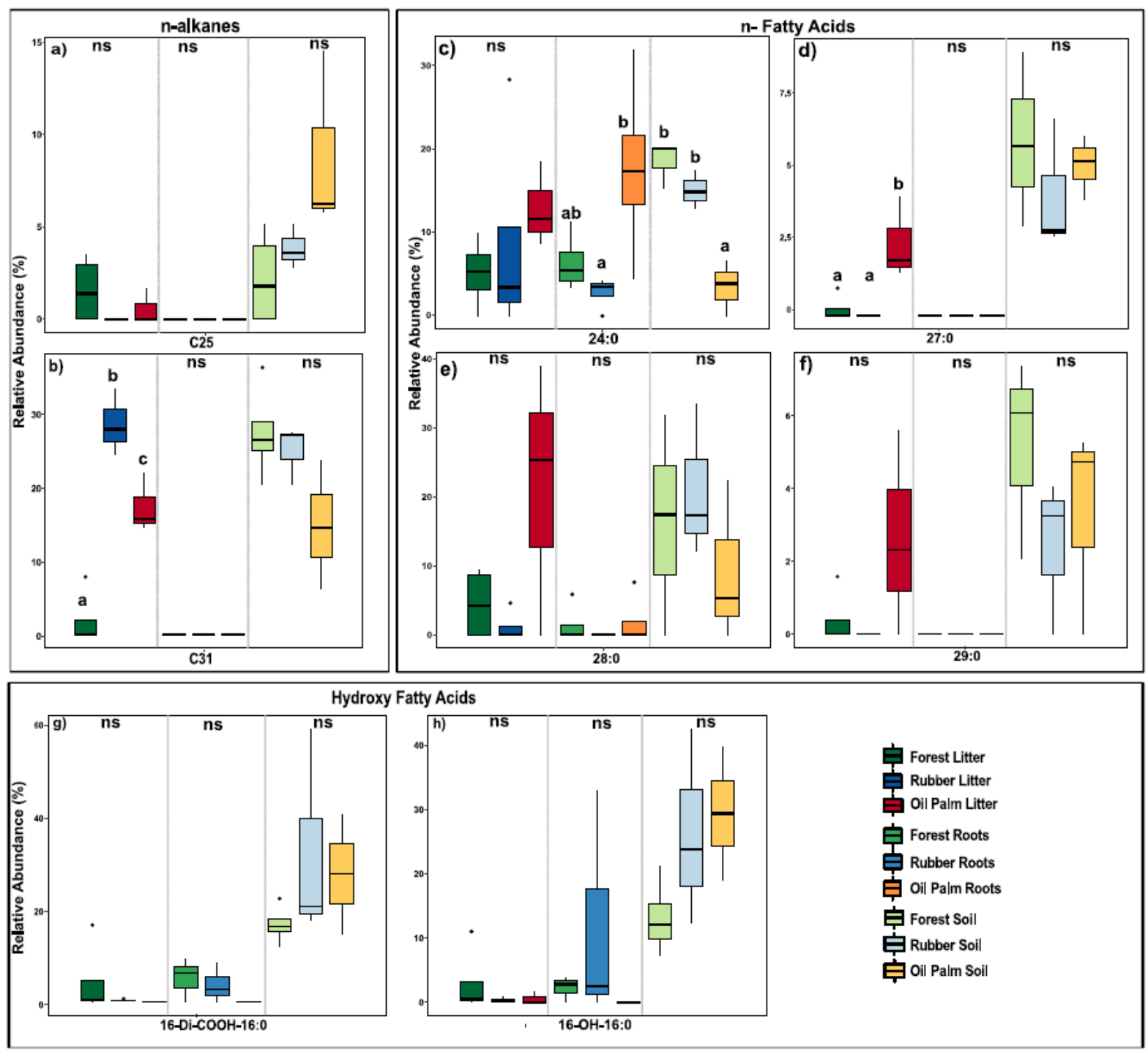

Figure 1.3-4: Plant-derived indicator biomarkers. Boxplots show medians, interquartiles distances and extreme values, which are displayed as bold lines, boxes with whiskers and dots, respectively. Litter, roots and soil $C$ pools are separated by grey lines. Different letters indicate significant differences according to One-Way ANOVA with TukeyHSD post-hoc comparison $(p<0.05)$.

Like long-chain n-alkanes, long-chain n-fatty acids are associated with plant origin (Harwood and Russel, 1984; Heinrich et al., 2015). The relative abundances of n-fatty acids 24:0 and 28:0 in oil palm litter accounted for $\sim 13 \%$ and $\sim 23 \%$ of the total oil palm litter fraction, respectively (Figure 1.3-4 c/e), showing a trend toward higher abundances than in forest or rubber litter. $24: 0$ in oil palm roots made up $~ 18 \%$ of the total fraction, showing as well a trend toward higher abundances than in forest and rubber roots (Figure 1.3-4 c). However, the pattern was vice versa in the topsoil with lowest relative contents in oil palm, indicating a stronger decomposition of the plant-derived 24:0 fatty acid in the topsoil of oil palm plantations than in rubber plantations' and forest topsoil. To prevent complete depletion of 24:0 and 28:0 by continuous decomposition, there must be an ongoing 
replenishment of these n-fatty acids by litter and roots, which is likely due to high abundances in these pools.

From the hydroxy fatty acid fraction, 16-OH-22:0 was found to separate oil palm and rubber soil and the di-acid 16-Di-COOH-16:0 was found to separate soils from litter and roots in all sites (Table 1.3-2). These components are suberin components and are root-associated (Pollard et al., 2008). Both substances have relatively high abundances in topsoils of all three land-use types. 16-OH-22:0 ranged between $16 \%$ in forest and $31 \%$ in rubber topsoil and 16-Di-COOH-16:0 varied between $15 \%$ in forest and $29 \%$ in oil palm soil of the total shares (Figure 1.3-4 g/h). Relative abundances of 16-OH-22:0 and 16-Di-COOH-16:0 in root samples were about $3 \%$ and $7 \%$ in forest roots and $17 \%$ and $5 \%$ in rubber roots. Both substances were not detected in oil palm roots. Thus, we cannot state an input by oil palm plant material. In forest litter samples relative abundances of 16-OH-16:0 and 16-Di-COOH16:0 were $3 \%$ and $7 \%$, respectively and in rubber litter both substances had a proportion of $0.04 \%$. Both substances were not detected in oil palm litter. We consequently assume that 16-OH-16:0 and 16-Di-COOH-16:0 in oil palm topsoils were derived from forest sources, especially because of their presence in similar relative abundances in forest soils (Figure 1.3-4 g/h). Thereby, 16-OH-16:0 and 16-Di-COOH-16:0 meet the requirement for a forestspecific biomarker for oil palm, that the substance should be present in forest litter and/or roots and soil, but not in oil palm and rubber litter and roots, i.e., the new organic matter input to plantation soils (Objective 2, Hypothesis b.) The high relative proportions in topsoils of all land - use types suggest an enrichment of these more recalcitrant compounds, while more easily decomposable lipids have already been degraded (Krull et al., 2003; Lorenz et al., 2007). For rubber plantations however, this interpretation of suberin accumulation and SOM degradation does not hold true, since there is a substantial amount of 16-OH-16:0 in rubber roots, excluding a contribution of forest vegetation as only possible source.

\subsubsection{TRANSFORMATION OF PLANT-DERIVED LIPID FINGERPRINTS BY MICROORGANISMS}

The odd-numbered n-fatty acids 27:0 and 29:0 had similar patterns since no content could be found in all root samples and in rubber litter (Figure 1.3-4d/f). Both substances had similar relative abundances in forest litter ( $1 \%$ of $27: 0$ and $1.5 \%$ of $29: 0)$ and slightly higher 
relative abundances in oil palm litter (2.5\% of 27:0 and 4\% of 29:0). Relative abundances of 27:0 in topsoils were within the same range (between $4 \%$ and $6 \%$ ). The n-fatty facid 29:0 varied between $4 \%$ and $5 \%$ in topsoils of all three land-use types. In contrast to the n-fatty acids 24:0 and 28:0, relative abundances of 29:0 in oil palm topsoil were not lower than in forest and rubber topsoil, suggesting no increased decomposition after forest conversion Figure 1.3-4 c/d/e/f). Although long-chain lipids are plant-associated, odd-chain fatty acids, such as 27:0 and 29:0, are no classical compounds of plant litter or roots but rather the product of microbial transformation of even-chain plant-derived fatty acids (Dippold and Kuzyakov, 2016). The low proportions in forest litter and the absence of 27:0 and 29:0 in rubber litter confirm this assumption. However, for 27:0 in oil palm litter, we cannot state this. Since proportions of both substances represent substantial constituents in topsoils of all three land-use types, it confirms the idea that they might be a product of microbial transformation in soils, leading to their accumulation. 27:0 and 29:0, are long-chain n-fatty acids, and are more resistant than short-chain fatty acids to further microbial decomposition. Similar to the n-alkanes $C_{25}$ and $C_{31}$ it also must be considered for the nfatty acids 27:0 and 29:0 that they can be partly derived from leaf-colonizing microbial residues, based on findings of Nguyen Tu et al. (2011). This assumption of litter colonization by microbial residues is further supported by high $\mathrm{C}_{16: 1+2}{ }^{*} \mathrm{C}_{16: 0^{-1}}$ ratios $(>0.1)$ in root samples (Study 3, Table 2.3-2), which indicate the contribution of microbial-derived compounds to the total fatty acid fraction, since $\mathrm{C}_{16: 1+2}$ fatty acids are common constituents of microbial tissues (Wiesenberg et al., 2010). However, n-fatty acids have a clear even-over-odd predominance (EOP) (Study 3, Figure 2.3-6) pattern, in contrast to n-alkanes which have an OEP, confirming the interpretation that 27:0 and 29:0 are rather products of microbial transformation than derived from microbial biomass colonization on leaves (Kollattukudy, 1980).

\subsubsection{MICROBIAL CONTRIBUTION TO THE CURRENT SOC POOL}

The fatty acid i15:0 was found to be indicative for rubber and oil palm topsoil (Figure 1.3-5a). It is a fatty acid commonly known as a biomarker for gram-positive bacteria and therefore from microbial origin (Osipov and Turova, 1997; Ritchie et al., 2000). This was confirmed by its absence in litter and root samples of all three land-use types (Figure 1.3-5a). Because i15:0 was found as free fatty acid in soil, although commonly extracted from phospholipids, it points towards the input by microbial necromass that contributed to SOM 
(Study 3). Low in degradability, gram-positive necromass, and mainly their cell envelopes, accumulates in topsoil with time. This might be here indicative for an relative accumulation of microbial necromass as Ludwig et al. (2015) found microbial mass (biomass and necromass) to be significant source for stable SOM in arable land. This agrees with the finding that microbial necromass accounts for a greater proportion of new SOC formation than non-microbial necromass in soils after land-use change and subsequent perennial grassland for bioenergy crop production (Zhu et al., 2020). This finding hints at another pathway of SOC formation, the so-called in-vivo microbial turnover pathway. Despite the fact that plants provide the initial input of $C$ to soil via litter and root exudation, it means that the turnover of organic substances occurred via cell uptake-biosynthesis-growth and death, which results in the long-term accumulation and stabilization of microbial-derived C (Liang et al., 2017).
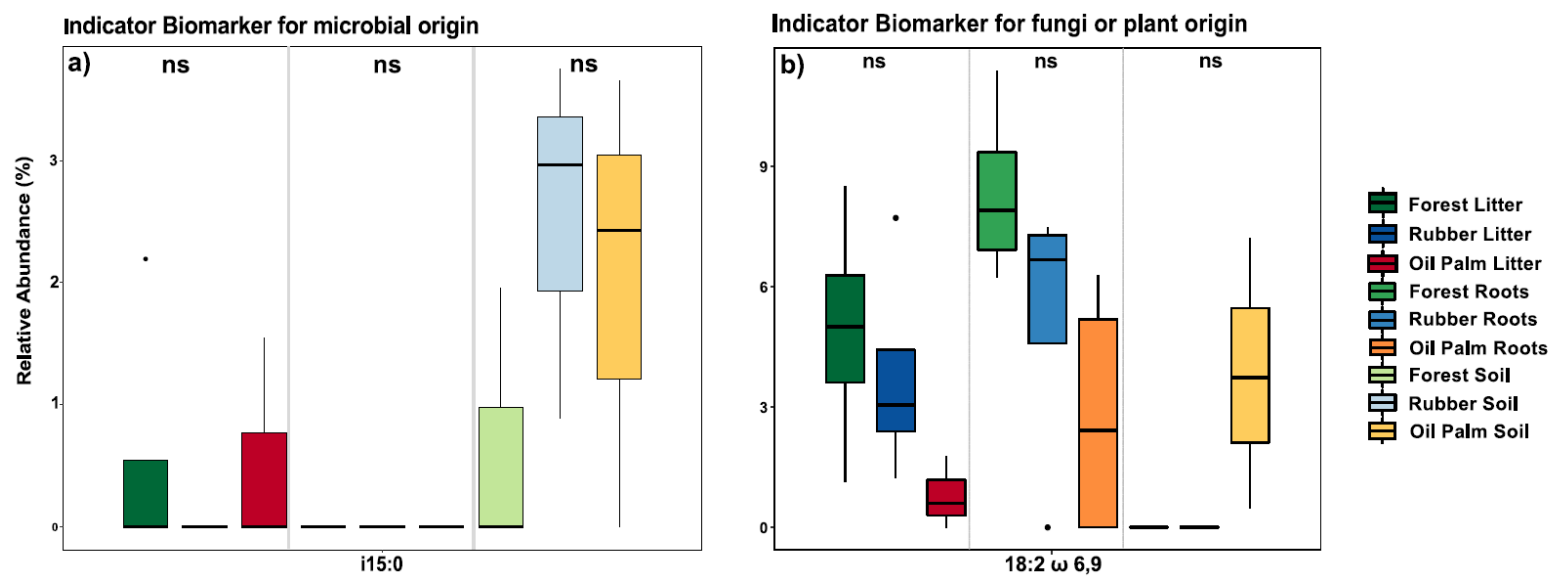

Figure 1.3-5: a) Microbial-derived biomarker. Boxplots show medians, interquartiles distances and extreme values, which are displayed as bold lines, boxes with whiskers and dots, respectively. Litter, roots and soil $C$ pools are separated by grey lines. No significant difference (ns) could be found according to One-Way ANOVA $(p<0.05)$ and $b)$ Indicator biomarker for fungi or plant origin. Boxplots show medians, interquartiles distances and extreme values, which are displayed as bold lines, boxes with whiskers and dots, respectively. Litter, roots and soil C pools are separated by grey lines. No significant difference (ns) could be found according to OneWay ANOVA $(p<0.05)$.

However, other fatty acids, such as 18:2 $\omega 6,9$, are metabolized much more rapidly, reflecting

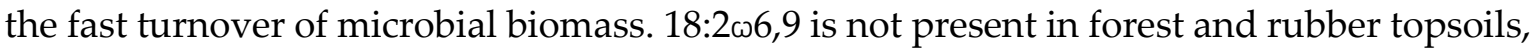
but accumulates in oil palm topsoil (Figure 1.3-5b). Further, the relative abundances of

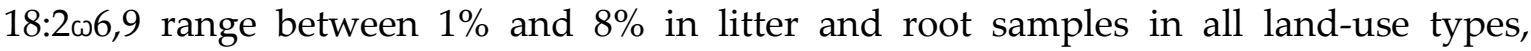
indicating an origin from plant membranes and not only from fungi. The fact that it accumulates in topsoil of oil palm plantations but not in forest and rubber plantations requires to consider different ongoing microbial processes: first, we can speculate about a 
shift in microbial community composition towards fungi upon conversion to oil palm plantations as it was also found in well-drained plantations (Krashevska et al., 2018, 2015) Second, the microbial community might have a weaker capability to decompose lipid compounds. Obstacles hampering the microbial community to degrade $18: 2 \omega 6,9$ can be quality differences of forest, rubber and oil palm litter. It was found that element ratios $(\mathrm{C}, \mathrm{N}, \mathrm{P})$ as well as lignin concentrations changed with the change in litter type (from forest to plantations). With these changes a change in bacterial, fungal and testate amoebae composition occured, which negatively affected litter decomposition rates (Krashevska et al., 2018), which our data would confirm for oil palm but not for rubber plantations, because in rubber plantations decompistion processes seems to be unaffected compared to oil palm plantatations where 18:2 $\omega 6,9$ relatively accumulates in topsoil. Since forest soils without

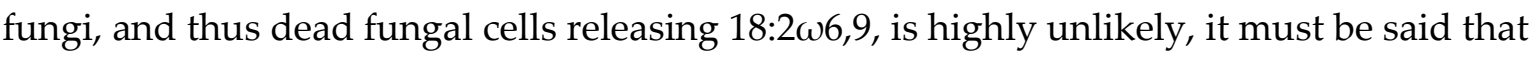
the absence of $18: 2 \omega 6,9$ in forest soil can most likely only be attributed to the rapid decomposition by microorganisms.

Combining multiple biomarkers, such as n-alkanes, n-fatty acids and hydroxy fatty acids help to disentangle a complex system of pathways of SOC formation. Single biomarkers, such as i15:0, indicate microbial necromass as an important $C$ source. Long-chain lipids and molecular proxies showed the importance of plant-derived $C$ input into soil, however the change of SOM composition shown by 27:0 and 29:0 highlighted the importance of microbial biomass by transforming OM during decomposition.

\subsubsection{SOC DECOMPOSITION UNDER DIFFERENT MANAGEMENT REGIMES}

Microorganisms not only play a crucial role in sequestering $C$ in soil, as described above, they are also essential for SOC decomposition and subsequent $\mathrm{CO}_{2}$ emissions from soil to the atmosphere. One of the urgent questions to answer, in terms of a sustainable agricultural use and adapting to climate change, is what effects agricultural management practices have on SOC decomposition (Hutchinson et al., 2007). Soils from two contrasting management practices (conventional NPK level and glyphosate and reduced NPK level with mechanical weeding as weed control) and from two management zones (WC and IR) were investigated under controlled conditions to gain a mechanistic understanding about the impact of one of the most common agricultural management practices on SOM decomposition (more details about the study design can be found in Figure 2.4-1, in chapter 
1.2.2.4 and in Study 4, chapter 2.4.3). Highest $\mathrm{CO}_{2}$ emissions were measured from WC under conventional NPK level with glyphosate application (0.04 $\left.\mathrm{mg} \mathrm{CO}_{2} \mathrm{~g}^{-1} \mathrm{day}^{-1}\right)$ (Study 4, Figure 2.4-2). $\mathrm{CO}_{2}$ efflux from soils in WC were always significantly higher than from IR across all management regimes, which differed not significantly from each other (Study 4 , Figure 2.4-2). $\mathrm{CO}_{2}$ emissions were four times higher from soil from the WC with conventional fertilizer level and herbicide application than in the corresponding IR. Higher $\mathrm{CO}_{2}$ emissions under conventional NPK amendment indicate increased microbial activity, due to enhanced nutrient availability (Marschner et al., 2003). This is in line with the hypothesis $3 a$ that a high fertilization level leads to higher microbial activity, and thus, increased soil $\mathrm{CO}_{2}$ emissions. The absence of glyphosate decreased $\mathrm{CO}_{2}$ emissions and thus SOC decomposition, while glyphosate application in combination with high amounts of fertilizers led to higher microbial activity and $\mathrm{CO}_{2}$ emissions, contradicting our expectations Study 4, Figure 2.4-2). Glyphosate had a positive effect on microbial activity because it probably served as an additional C source for microorganisms. This effect has been reported before, particularly after several years of repeated glyphosate application (Araújo et al., 2003; Busse et al., 2001), which is consistent with the conditions on the oil palm plantation under investigation. Further, the concentration of gly phosate applied, seemed to play a distinct role influencing microbial activity and thus respiration: There are several studies showing an increase or a decrease of microbial respiration after glyphosate application (Abood et al., 2015; Duke et al., 2012; Guijarro et al., 2018; Haney et al., 2000). The studies, however, varied strongly in applied glyphosate concentration, repeated amendments and experimental design. Nguyen et al., (2016) determined a threshold of 200 mg $\mathrm{kg}^{-1}$ soil of glyphosate, above which soil microbial respiration increased. Since glyphosate concentration in this laboratory experiment was $375 \mathrm{mg} \mathrm{kg}^{-1}$, resembling field application conditions, those findings agree with our interpretation that glyphosate rather stimulates than lowers microbial activity. The metabolic quotient $\left(q \mathrm{CO}_{2}\right)$ supports this interpretation, since it tended to be higher in WC with glyphosate application compared to WC without glyphosate application (Study 4, Figure 2.4-3). Additionally, fertilizer itself and soil properties influence the effect of glyphosate on microbial activity: first, phosphate from fertilizer compete for the same sorption sites on soil particles (Jonge and Jonge, 1999; Munira et al., 2018). When fertilizer and glyphosate are applied at the first time this effect is especially strong, because pre-sorbed phosphate occupies sorption sites otherweise 
available to glyphosate (Gimsing et al., 2007; Munira et al., 2018). Further, soils like sandy loam Acrisols exacerbate this phenomenon, by providing only a reduced number of sorption sites compared to fine textured soils, which would have slowed down glyphosate degradation (Guijarro et al., 2018). Thus, due to the reduced number of sorption sites in our soil, glyphosate is available for microbial decomposition processes, thus we assume no systemtic inhibition of microbial activity caused by glyphosate application. Second, the soil samples from the oil palm plantation had $\mathrm{pH}$-values between 4.8 and 5.3, clearly highlighting acidic soil conditions. Soil microbial biomass and soil microbial respiration are more sensitive toward glyphosate in soils having a $\mathrm{pH}$ between $5.5-7.5$ than in soils with a $\mathrm{pH}<5.5$ (Nguyen et al., 2016). Third, Nguyen et al., (2016) postulated an increase of microbial respiration and a reduction of soil microbial biomass in soils with low OC content, which agrees with OC content measured in oil palm plantation soils $(0.78 \%-2.1 \%$ in IR and WC), but we cannot state a reduction of soil microbial biomass. We rather consider a long-term adapted microbial community after several years of glyphosate application, whereas Nguyen et al. (2016) proposed soils with low OC content to be limited in microbial functionality and less well buffered against stress factors. This might be a valid interpretation, especially for soils undergoing its first glyphosate application. They further postulated less resilient parts of the soil microbial community may have been inhibited by a high glyphosate concentration, while more resistant groups compensate their functions and are accountable for the increased soil respiration. Since one year after the start of the corresponding field experiment, no significant differences for biodiversity or community composition between the different treatments at the entire (DNA-derived) and active (RNA-derived) community level were detected (Berkelmann et al., 2020), we, therefore, propose rather an increase of microbial activity across the whole community than a compensation of functions by special species.

Lower basal respiration rates in IR than in WC can be explained by the lack of fertilizers in the IR, leading to a reduced nutrient supply for microorganisms (Study 4, Figure 2.4-2). Neither glyphosate application nor the absence of glyphosate had an effect on basal respiration between the IR under different management practices. Since no signficant differences could be stated, the location of IR next to either high fertilized WC or low fertilized WC does not seem to play a distinct role, indicating that nutrient allocation from the WC to the IR can largely be excluded. Generally, oil palm plantation soils often suffer 
from nutrient and $\mathrm{C}$ limitation, due to the absence of fresh organic input, low root biomass, low rhizodeposition (Guillaume et al., 2018; Pransiska et al., 2016; Rüegg et al., 2019) and high nutrient leaching (Kurniawan et al., 2018). IR receive even less nutrients due to the absence of fertilizers and less $C$ due to the absence of litter and oil palm rhizodeposits, suggesting C-limitation is strong across all management practices and restricts microbial activity. In the incubation experiment, $\mathrm{C}$ limitation was removed by adding glucose, simulating rhizodeposits by providing a labile $C$ source, that led to a quick activation of microorganisms. This activation was expecially pronounced in samples from IR, where highest glucose respiration rates were measured shortly after glucose amendment (Study 4, Figure 2.4-4, Appendix A 2.4-1). C limitation in IR seems to be the most limiting factor of microbial activity and was removed by glucose $\mathrm{C}$ addition. Consequently, the glucose was rapidly metabolized and respired. C limitation in oil palm plantations can be assigned to missing organic input, i.e., missing litterfall and understory vegetation, which has a severe effect on C sequestration in soil (Kotowska et al., 2015; Rüegg et al., 2019).

Cumulative priming effects, indicating SOC decomposition, were almost always negative (Figure 1.3-6), except if glyphosate was applied together with conventional NPK levels in WC or reduced fertilization levels in IR, which showed the absence of any priming effect. Overall, less intensive management practices increased negative priming effects in WC, with strongest negative priming $\left(-47.9 \mathrm{\mu g} \mathrm{C}^{-1}\right)$ under low fertilization and the absence of glyphosate, compared to any other location or any other treatment. 


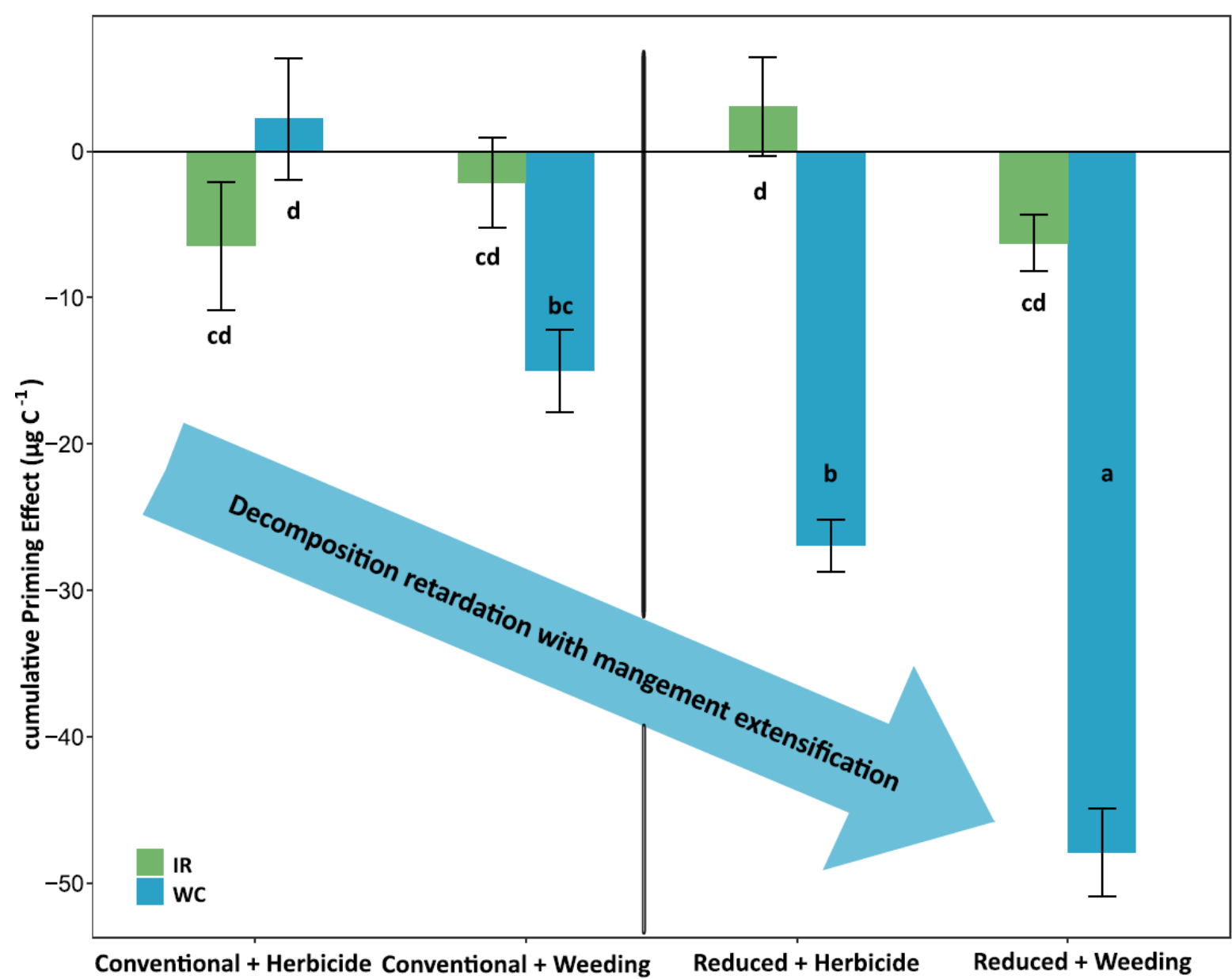

Figure 1.3-6: Cumulative Priming Effects across all management practices and locations after 33 days of soil incubation of the soil from the conventional fertilization with herbicide and mechanical weeding and reduced fertilization with herbicide and mechanical weeding. Data are presented as means $(n=4)$. Error Bars indicate the standard error of mean. Letters indicate significant differences between fertilizer, herbicide and locations according to 3-Way-ANOVA with TukeyHSD post-hoc comparison $(p<0.05)$.

As explained above, intensive management practices caused higher basal respiration, i.e., accelerated SOM decomposition under C limitation. Yet, there was no additional acceleration of SOC decomposition, i.e., a positive priming effect, when removing $\mathrm{C}$ limitation by adding an easy-available substrate. In contrast, negative priming effects under less intensive management practices indicate reduced SOC mineralization and rather suggest a promotion of belowground $C$ stabilization. This finding contradicts the hypothesis $3 \mathrm{~b}$ that glyphosate application would increase SOC sequestration due to hampering soil microbial activity by deactivating the shikimate pathway, leading to a decreased microbial respiration. Further, $\mathrm{C}$ stabilization can be fostered by $\mathrm{C}$ derived from microorganisms, i.e., fungal and bacterial necromass, and sequestered in substantial quantities in the stable C pool (Kindler et al., 2006; Liang et al., 2017; Schweigert et al., 2015), contributing to long-term SOC accumulation. This is supported by findings from Study 3 , 
where microbial-derived fatty acids found in soil of oil palm plantations pointed to an accumulation of microbial necromass and therefore an increasing stable C pool (Study 3, Ludwig et al., 2015; Zhu et al., 2020). Nevertheless, it is essential to ensure above- and belowground $C$ input, i.e., frond piling, application of empty fruit bunches (EFB) as $C$ sources. Besides, increasing potential of $\mathrm{C}$ incorporation into soil, organic input and extensification of management practices also account for an enhancement of soil fauna growth (Tao et al., 2017), improving key ecosystem functions, such as higher animal taxa richness and microbial biomass abundance (Darras et al., 2019).

In addition to the use of mineral fertilizers and herbicide, organic fertilization options exist, and are especially often applied by smallholder farmers, who mulch with EFB in their oil palm plantations. SOC contents from plantations, mulched with EFB in the WC, showed an increase of $19 \%$ compared to soil in plantations, where no EFB was applied (Rudolf, 2020).

\subsection{Conclusions and Implications}

The aims of this dissertation were to evaluate land-use change effects on SOC turnover, losses and SOM composition in riparian rubber and oil palm plantations after forest conversion compared to well-drained plantations and to investigate the effects of different agricultural management practices on SOC decomposition in a well-drained oil palm plantation. It was possible to identify the dominant processes of SOC losses which were affected by specific riparian properties and different agricultural management regimes. The strength and significance of this work results from the combination of different analytical methods, ranging from field work (Study 1 and 2) to laboratory extraction procedures (Study 3) to an experiment under controlled conditions (Study 4), to gain a mechanistic understanding of the underlying processes ongoing in the different land-use types. Based on the results about changes in SOC stocks, SOM composition and microbial biomass activities, a final assessment of SOC decomposition processes and SOC sequestration potentials is provided.

\subsubsection{LANDSCAPE AND LAND-USE EFFECTS DETERMINE SOC DECOMPOSITION AFTER FOREST CONVERSION}

Decomposition processes in forest, rubber and oil palm plantations were strongly dependent on riparian properties, which countered the expected effects of land-use change. This was reflected in higher SOC stocks in riparian areas than in well-drained areas and 
differing $\delta^{13} \mathrm{C}$ depth profiles patterns among the land-use and landscape types (Study 2). Applying $\delta^{13} \mathrm{C}$ values was an efficient strategy to analyze and understand SOC decomposition after land-use change and under specific landscape conditions. Analysis of $\delta^{13} \mathrm{C}$ depth profiles patterns even made it possible to elaborate a land-use effect and a riparian landscape effect that affect topsoil and subsoil differently. $\delta^{13} \mathrm{C}$ patterns indicated a land-use effect in the topsoil, since higher values in plantations than in forest hinted at accelerated mineralization under oxic conditions. In deeper soil layers $(>15 \mathrm{~cm})$ of plantations and in the forest, $\delta^{13} \mathrm{C}$ patterns revealed a strong landscape-specific effect, with uniform (forest) as well as irregular depth profiles (plantations) confirming changing aerobic and anaerobic SOC decomposition due to periodical flooding. Supported by rapidly changing GWTs with high amplitudes, it became clear that alternating oxic and anoxic conditions play distinct roles in regulating SOC decomposition and storage. Further, landuse change driven effects, such as an in increase in soil bulk densities, lowers water infiltration into soil, and thus supports prolonged anoxic condtions with delayed SOC decomposition (Study 1,2). Additionally, compacted soil supported surface runoff, favoring erosion and deposition events, which are riparian-specific processes, influencing SOC balance by transporting SOM of different degradation status in and out of the riparian areas, which was also reflected by irregular $\delta^{13} \mathrm{C}$ patters. At first, it can be assumed that compared to well-drained areas, riparian areas are more resilient to short-term (1-2 decades) soil C loss after land-use change, as topsoils showed similar C stocks compared to that under natural vegetation. However, accelerated mineralization in the topsoil indicated possible long-term effects on $\mathrm{C}$ storage caused by land-use change, since riparian areas, especially if drained, have a high $\mathrm{C}$ loss potential, considering the high amounts of subsoil $\mathrm{C}$ in their buried C-rich layers. Effects of land-use change on SOC is therefore already reflected by the $\delta^{13} \mathrm{C}$ pattern in the topsoil, but cannot be detected by a decrease of the SOC stock yet.

\subsubsection{SOC FORMATION PATHWAYS}

Since SOC stocks in topsoils of forest, rubber and oil palm plantations were similar, it leads to the assumption that $C$ is preserved over a long period of time and that $C$ produced in the forest still contributes to the current SOC pool in the topsoil of plantations. Plant-derived C is one of the major sources for SOC. Long-chain lipids, such as 24:0 and 28:0 n-fatty acids as well as $\mathrm{C}_{25}$ and $\mathrm{C}_{31} \mathrm{n}$-alkanes with distinctive EOP and OEP patterns confirmed the 
importance of plant-derived C incorporated into topsoil. Similar relative abundances between forest and plantations' topsoils were interpretated as contribution of forestgenerated $\mathrm{C}$ to the current SOC pool in plantations. Based on a strong dominance of the nalkanes $C_{31}$ and $C_{33}$ over $C_{27}$ and $C_{29}$ in forests and rubber plantations, it is assumed that the dense herb layer in rainforests and the grass cover in rubber plantations dominate $C$ input over trees and shrubs. $\mathrm{N}$-alkane distributions in oil palm plantations, often having a bare soil or a fragmented grass layer, do not show this pattern. Clearest evidence of forest $\mathrm{C}$ contribution to plantations is given by $16-\mathrm{OH}-22: 0$ and 16-Di-COOH-16:0, because of relatively high abundances in topsoils of all three land-use types, underlined by very low abundances in oil palm litter indicating neglectable input by oil palm litter itself. These substances account for a significant share as SOM source in forest, since 16-OH-16:0 made up $\sim 29 \%$ and 16-Di-COOH-16:0 comprised $\sim 28 \%$ of the total lipid fraction of oil palm topsoils. The high relative proportion in topsoils suggest an enrichment of these more recalcitrant compounds, while more easily decomposable lipids have already been degraded (Krull et al., 2003; Lorenz et al., 2007), highlighting the sequestration into the stable C pool. Identified pathways of SOC formation are via microbial biomass as the free

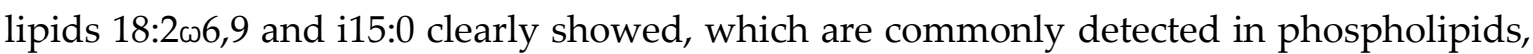
but here are found as free lipids in soil samples, indicating decomposition of microbial biomass to necromass. We found that the in-vivo microbial turnover pathway plays a

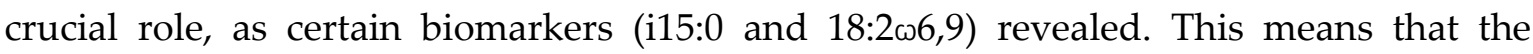
turnover of organic substances occurred via cell uptake-biosysnthesis-growth and death the so-called microbial C pump - and resulted in the long-term accumulation of microbialderived C (Liang et al., 2017). Driven by the rapid turnover of microorganisms, necromass directly contributes to the soil stable $\mathrm{C}$ pool. Further the ability of microorganisms to continuously process $\mathrm{C}$ and produce microbial-derived compounds that accumulate in soils is excellently displayed by the presence of odd-chain fatty acids, such as 27:0 and 29:0, which emphasize the importance of the microbial community as decomposers and transformers of plant-derived material.

\subsubsection{MANAGEMENT PRACTICES AFTER LAND-USE CHANGE AFFECT SOC DECOMPOSITION}

Soil microorganisms play a double role: they have the ability to produce biomass to be stabilized as SOM leading soil $\mathrm{C}$ sequestration due to their anabolic activity and they 
decompose SOC releasing it as $\mathrm{CO}_{2}$ to the atmosphere due to their catabolic activity. Especially, when adding new easily available $\mathrm{C}$, SOC destabilizes and $\mathrm{CO}_{2}$ emissions can increase, which is known as the priming effect. Controlled conditions in a laboratory experiment made it possible to draw conclusions about the effects of NPK fertilization and glyphosate application as weed control on SOC decomposition. It became clear that high fertilization and herbicide application accelerated microbial respiration, because NPK in combination with glyphosate acted as additional nutrient source. Extensive management practices i.e., reduced fertilizer level and the absence of glyphosate, reduced SOC decomposition and, thus, supported $\mathrm{C}$ accumulation. Following up on the urgent question of which strategies for $\mathrm{C}$ storage can be successful after land-use change, it was shown that extensive management practices with reduced fertilization levels + mechanical weeding instead of herbicide application have a high potential to slow down SOM decomposition processes and support $\mathrm{C}$ accumulation after forest conversion to oil palm plantations. Accelerated microbial respiration and SOC decomposition, however, emphasize the risk of commonly used management practices i.e., high NPK fertilization and glyphosate application, of allowing oil palm plantations to become a $\mathrm{CO}_{2}$ source.

This study showed how combining different methods lead to a comprehensive assessment of SOC losses, but also SOC sequestration potential as well as the change of SOM composition after conversion of forest to rubber and oil palm monocultures. The conclusions suggest that after land-use change in riparian areas, $\mathrm{C}$ storage is put on a high risk especially if soils are drained, because of its higher SOC stocks, particularly in the subsoil than in well- drained soils. Other features of riparian areas, such as high amplitudes of GWTs, can influence SOC balance up to a hitherto unpredictable extend. Related changes in the molecular composition of SOM might have unknown implications for ecosystem functions and the stability of this $C$ pool. It is, thus, questionable whether these soils can be restored to a qualitatively similar form like their previous pristine state and with a similar SOC sequestration potential. Additionally, in most of the monocultures there are additional disturbances in the form of management activities. The results of SOC decomposition in oil palm plantation soils under intensive management practices clearly indicate further SOC depletion after plantations establishment, jeopardizing a new $\mathrm{C}$ equilibrium. A change to extensive management practices, with lower fertilization levels and mechanical weed 
control and in best case with EFB mulching, is a very promising method to slow down SOC decomposition processes and supporting SOC sequestration.

\subsection{Contribution to studies}

Study 1: Flooding and land-use change in Jambi Province, Sumatra: integrating local knowledge and scientific enquiry

Status: Published in: Ecology and Society (2020), https://doi.org/10.5751/ES-11678250314

\begin{tabular}{ll}
\hline Authors & Contribution \\
\hline Jennifer Merten & Study design, field work, data analysis, writing \\
Christian Stiegler & Study design, field work, data analysis, writing \\
Nina Hennings & Field work, data analysis, writing, commenting \\
Edwine S. Purnama & Data analysis, commenting \\
Alexander Röll & Data analysis, writing, commenting \\
Herdhata Agusta & Data contribution, commenting \\
Michaela A. Dippold & Study design, commenting \\
Lutz Fehrmann & Study design, commenting \\
Dodo Gunawan & Study design, commenting \\
Dirk Hölscher & Study design, commenting \\
Alexander Knohl & Study design, commenting \\
Johanna Kückes & Data contribution \\
Fenna Otten & Data contribution, commenting \\
Deplhine C. Zemp & Data contribution, commenting \\
Heiko Faust & Study design, commenting \\
\hline
\end{tabular}

Study 2: Riparian wetland properties counter the effect of land use change on soil carbon stocks after rainforest conversion to plantations

Status: Published in Catena (2021), https://doi.org/10.1016/j.catena.2020.104941

\begin{tabular}{ll}
\hline Authors & Contribution \\
\hline Nina Hennings & Study design, field work, laboratory work; data analysis; \\
& writing \\
Joscha N. Becker & Data analysis, commenting \\
Thomas Guillaume & Data contribution, commenting \\
Muhammad Damris & Field work, commenting \\
Michaela A. Dippold & Study design, commenting \\
Yakov Kuzyakov & Study design, commenting \\
\hline
\end{tabular}


Study 3: Reconstructing the sources of soil organic matter after land-use change using a multiple biomarker approach

Status: final Manuscript

\begin{tabular}{ll}
\hline Authors & Contribution \\
\hline Nina Hennings & $\begin{array}{l}\text { Study design, field work, laboratory work, data analysis, } \\
\text { writing }\end{array}$ \\
\hline Yakov Kuzyakov & $\begin{array}{l}\text { Study design, commenting } \\
\text { Michaela A. Dippold }\end{array}$ \\
\hline
\end{tabular}

Study 4: Intensive management practices in oil-palm plantations and the impact to soil organic matter decomposition

Status: Manuscript submitted to Soil Biology and Biochemistry

\begin{tabular}{ll}
\hline Authors & Contribution \\
\hline Nina Hennings & $\begin{array}{l}\text { Study design, field work, laboratory work, data analysis, } \\
\text { wrriting }\end{array}$ \\
Katharina M. Fricke & Laboratory work, data analysis, commenting \\
Muhammad Damris & Field work \\
Michaela A. Dippold & Study design, commenting \\
Yakov Kuzyakov & Study design, commenting \\
\hline
\end{tabular}




\section{References}

Abood, S.A., Ser, J., Lee, H., Burivalova, Z., Garcia-ulloa, J., Koh, L.P., 2015. Relative Contributions of the Logging , Fiber , Oil Palm , and Mining Industries to Forest Loss in Indonesia 8, 58-67. https://doi.org/10.1111/conl.12103

Alewell, C., Giesler, R., Klaminder, J., Leifeld, J., Rollog, M., 2011. Stable carbon isotopes as indicators for environmental change in palsa peats. Biogeosciences 8, 1769-1778. https://doi.org/10.5194/bg-8-1769-2011

Amelung, W., Brodowski, S., Sandhage-Hofmann, A., Bol, R., 2008. Chapter 6 Combining Biomarker with Stable Isotope Analyses for Assessing the Transformation and Turnover of Soil Organic Matter, 1st ed, Advances in Agronomy. Elsevier Inc. https://doi.org/10.1016/S00652113(08)00606-8

Andreeva, D.B., Zech, M., Glaser, B., Erbajeva, M.A., Chimitdorgieva, G.D., Ermakova, O.D., Zech, W., 2013. Stable isotope $(\delta 13 C, \delta 15 N, \delta 180)$ record of soils in Buryatia, southern Siberia: Implications for biogeochemical and paleoclimatic interpretations. Quat. Int. 290-291, 82-94. https://doi.org/10.1016/j.quaint.2012.10.054

Araújo, A.S.F., Monteiro, R.T.R., Abarkeli, R.B., 2003. Effect of glyphosate on the microbial activity of two Brazilian soils. Chemosphere 52, 799-804. https://doi.org/10.1016/S0045-6535(03)002662

Ashton-Butt, A., Aryawan, A.A.K., Hood, A.S.C., Naim, M., Purnomo, D., Suhardi, Wahyuningsih, R., Willcock, S., Poppy, G.M., Caliman, J.-P., Turner, E.C., Foster, W.A., Peh, K.S.-H., Snaddon, J.L., 2018. Understory Vegetation in Oil Palm Plantations Benefits Soil Biodiversity and Decomposition Rates. Front. For. Glob. Chang. 1. https://doi.org/10.3389/ffgc.2018.00010

Austin, K.G., Schwantes, A., Gu, Y., Kasibhatla, P.S., 2019. What causes deforestation in Indonesia? Environ. Res. Lett. 14, 24007. https://doi.org/10.1088/1748-9326/aaf6db

Baccini, A., Walker, W., Carvalho, L., Farina, M., Houghton, R.A., 2019. Response to Comment on "Tropical forests are a net carbon source based on aboveground measurements of gain and loss." Science (80-. ). 363, 230-234. https://doi.org/10.1126/science.aat1205

Becker, J., Pabst, H., Mnyonga, J., Kuzyakov, Y., 2015. Annual litterfall dynamics and nutrient deposition depending on elevation and land use at Mt. Kilimanjaro. Biogeosciences 12, 56355646. https://doi.org/10.5194/bg-12-5635-2015

Bendix, J., Hupp, C.R., 2000. Hydrological and geomorphological impacts on riparian plant communities. Hydrol. Process. 14, 2977-2990. https://doi.org/10.1002/10991085(200011/12)14:16/17<2977::AID-HYP130>3.0.CO;2-4

Berkelmann, D., Schneider, D., Hennings, N., Meryandini, A., Daniel, R., 2020. Soil bacterial community structures in relation to different oil palm management practices. Sci. Data 7, 1-7. https://doi.org/10.1038/s41597-020-00752-3

Blagodatskaya, E. V., Blagodatsky, S.A., Anderson, T.H., Kuzyakov, Y., 2007. Priming effects in Chernozem induced by glucose and $\mathrm{N}$ in relation to microbial growth strategies. Appl. Soil Ecol. 37, 95-105. https://doi.org/10.1016/j.apsoil.2007.05.002

Blagodatsky, S., Xu, J., Cadisch, G., 2016. Carbon balance of rubber (Hevea brasiliensis) plantations: A review of uncertainties at plot, landscape and production level. Agric. Ecosyst. Environ. 221, 8-19. https://doi.org/10.1016/j.agee.2016.01.025

Blanco-Canqui, H., Benjamin, J.G., 2013. Impacts of soil organic carbon on soil physical behavior, in: Sally Logsdon, Markus Berli, R.H. (Ed.), Quantifying and Modeling Soil Structure Dynamics. Soil Science Society of America, Inc., pp. 11-40. https://doi.org/10.2134/advagricsystmodel3.c2

Borchard, N., Bulusu, M., Meyer, N., Rodionov, A., Herawati, H., Blagodatsky, S., Cadisch, G., Welp, G., Amelung, W., Martius, C., 2019. Deep soil carbon storage in tree-dominated land use systems in tropical lowlands of Kalimantan. Geoderma 354, 113864. https://doi.org/10.1016/j.geoderma.2019.07.022

Brown, S., Brinson, M. M., Lugo, A.E., 1978. Structure and Function of Riparian Wetlands, in: Johnson, R. R., McCormick, J.F. (Ed.), Strategies for Protection and Management of Floodplain 
Wetlands and Other Riparian Ecosystems. U.S. Department of Agriculture. Forest Service, Washington D.C., pp. 17-31.

Bruijnzeel, L. A. 2004. Hydrological functions of tropical forests: not seeing the soil for the trees? Agriculture, Ecosystems and Environment 104(1):185-228. https://doi.org/10.1016/j.agee.2004.01.015

Burger, K.; Smit, H.P., 2001. International Market Responses to the Asian Crisis for Rubber, Cocoa and Coffee, in: Gérard, F.; Ruf, F. (Ed.), Agriculture in Crisis: People, Commodities and Natural Resources in Indonesia, 1996-2000. Curzon Press, Richmond, UK, pp. 31-48.

Bush, R.T., McInerney, F.A., 2013. Leaf wax n-alkane distributions in and across modern plants: Implications for paleoecology and chemotaxonomy. Geochim. Cosmochim. Acta 117, 161-179. https://doi.org/10.1016/j.gca.2013.04.016

Busse, M.D., Ratcliff, A.W., Shestak, C.J., Powers, R.F., 2001. Glyphosate toxicity and the effects of long-term vegetation control on soil microbial communities. Soil Biol. Biochem. 33, 1777-1789. https://doi.org/10.1016/S0038-0717(01)00103-1

Ciais, P., Sabine, C., Bala, G., Bopp, L., Brovkin, V., Canadell, J., Chhabra, A., DeFries, R., Galloway, J., Heimann, M., Jones, C., Quéré, C. Le, Myneni, R.B., Piao, S., Thornton, P., 2013. Carbon and other biogeochemical cycles, Climate Change 2013 the Physical Science Basis: Working Group I Contribution to the Fifth Assessment Report of the Intergovernmental Panel on Climate Change. https://doi.org/10.1017/CBO9781107415324.015

Chiti, T., Grieco, E., Perugini, L., Rey, A., Valentini, R., 2014. Effect of the replacement of tropical forests with tree plantations on soil organic carbon levels in the Jomoro district, Ghana. Plant Soil 375, 47-59. https://doi.org/10.1007/s11104-013-1928-1

Clough, Y., Krishna, V. V., Corre, M.D., Darras, K., Denmead, L.H., Meijide, A., Moser, S., Musshoff, O., Steinebach, S., Veldkamp, E., Allen, K., Barnes, A.D., Breidenbach, N., Brose, U., Buchori, D., Daniel, R., Finkeldey, R., Harahap, I., Hertel, D., Holtkamp, A.M., Hörandl, E., Irawan, B., Jaya, I.N.S., Jochum, M., Klarner, B., Knohl, A., Kotowska, M.M., Krashevska, V., Kreft, H., Kurniawan, S., Leuschner, C., Maraun, M., Melati, D.N., Opfermann, N., Pérez-Cruzado, C., Prabowo, W.E., Rembold, K., Rizali, A., Rubiana, R., Schneider, D., Tjitrosoedirdjo, S.S., Tjoa, A., Tscharntke, T., Scheu, S., 2016. Land-use choices follow profitability at the expense of ecological functions in Indonesian smallholder landscapes. Nat. Commun. 7. https://doi.org/10.1038/ncomms13137

Comte, I., Colin, F., Grünberger, O., Follain, S., Whalen, J.K., Caliman, J.P., 2013. Landscape-scale assessment of soil response to long-term organic and mineral fertilizer application in an industrial oil palm plantation, Indonesia. Agric. Ecosyst. Environ. 169, 58-68. https://doi.org/10.1016/j.agee.2013.02.010

Corley, R.H.V., Tinker, P.B., 2015. The Oil Palm: Fifth Edition, Fifth Edid. ed, The Oil Palm: Fifth Edition. Wiley Blackwell, Oxford, UK. https://doi.org/10.1002/9781118953297

Craig, H., 1953. The geochemistry of the stable carbon isotopes. Geochim. Cosmochim. Acta. https://doi.org/10.1016/0016-7037(53)90001-5

Crow, S.E., Lajtha, K., Filley, T.R., Swanston, C.W., Bowden, R.D., Caldwell, B.A., 2009. Sources of plant-derived carbon and stability of organic matter in soil: Implications for global change. Glob. Chang. Biol. 15, 2003-2019. https://doi.org/10.1111/j.1365-2486.2009.01850.x

Curtis, P.G., Slay, C.M., Harris, N.L., Tyukavina, A., Hansen, M.C., 2018. Classifying drivers of global forest loss. Science (80-. ). 361, 1108-1111. https://doi.org/10.1126/science.aau3445

Darras, K.F.A., Corre, M.D., Formaglio, G., Tjoa, A., Potapov, A., Manning, F.C., 2019. Reducing Fertilizer and Avoiding Herbicides in Oil Palm Plantations - Ecological and Economic Valuations. Front. For. Glob. Chang. 2. https://doi.org/10.3389/ffgc.2019.00065

Davies, S.J., Leng, M.J., MacQuaker, J.H.S., Hawkins, K., 2012. Sedimentary process control on carbon isotope composition of sedimentary organic matter in an ancient shallow-water shelf succession. Geochemistry, Geophys. Geosystems 13, 1-15. https://doi.org/10.1029/2012GC004218

de Blécourt, M., Brumme, R., Xu, J., Corre, M.D., Veldkamp, E., 2013. Soil Carbon Stocks Decrease 
following Conversion of Secondary Forests to Rubber (Hevea brasiliensis) Plantations. PLoS One 8. https://doi.org/10.1371/journal.pone.0069357

Décamps, H, Pinay, G, Naiman RH, Petts, GE, McClain, ME, Hillerecht-Ilkowska, A, Hanley, TA, Holmes, RM, Quinn, J, Gibert, J, Planty Tabacchi, A-M, Schiemer, F, Tabacchi, E, Zalewski, M., 2004. Riparian zones: where biogeochemistry meets biodiversity in management practice. Polish J. Ecol.

de Junet, A., Abril, G., Guérin, F., Billy, I., de Wit, R., 2005. Sources and transfers of particulate organic matter in a tropical reservoir (Petit Saut, French Guiana): a multi-tracers analysis using \&delta;13C, C/N ratio and pigments. Biogeosciences Discuss. 2, 1159-1196. https://doi.org/10.5194/bgd-2-1159-2005

Derrien, D., Marol, C., Balesdent, J., 2007. Microbial biosyntheses of individual neutral sugars among sets of substrates and soils. Geoderma 139, 190-198. https://doi.org/10.1016/j.geoderma.2007.01.017

Dippold, M.A., Kuzyakov, Y., 2016. Direct incorporation of fatty acids into microbial phospholipids in soils: Position-specific labeling tells the story. Geochim. Cosmochim. Acta 174, 211-221. https://doi.org/10.1016/j.gca.2015.10.032

Dirzo, R., Raven, P.H., 2003. Global State of Biodiversity and Loss. Annu. Rev. Environ. Resour. 28, 137-167. https://doi.org/10.1146/annurev.energy.28.050302.105532

Don, A., Schumacher, J., Freibauer, A., 2011. Impact of tropical land-use change on soil organic carbon stocks - a meta-analysis. Glob. Chang. Biol. https://doi.org/10.1111/j.13652486.2010.02336.x

Drescher J, Rembold K, Allen K, Beckschäfer P, Buchori D, Clough Y, Faust H, Fauzi AM, Gunawan D, Hertel D, Irawan B, Jaya INS, Klarner B, Kleinn C, Knohl A, Kotowska MM, Krashevska V, Krishna V, Leuschner C, Lorenz W, Meijide A, Melati D, Nomura M, Pérez, K.H. and S.S., 2016. Ecological and socio-economic functions across tropical land use systems after rainforest conversion. Philos. Trans. R. Soc. B Biol. Sci. 371, 20150275. https://doi.org/10.1098/rstb.2015.0275

Drollinger, S., Kuzyakov, Y., Glatzel, S., 2019. Effects of peat decomposition on $\delta^{13} \mathrm{C}$ and $\delta^{15} \mathrm{~N}$ depth profiles of Alpine bogs. Catena 178, 1-10. https://doi.org/10.1016/j.catena.2019.02.027

Duke, S.O., Lydon, J., Koskinen, W.C., Moorman, T.B., Chaney, R.L., Hammerschmidt, R., 2012. Glyphosate effects on plant mineral nutrition, crop rhizosphere microbiota, and plant disease in glyphosate-resistant crops. J. Agric. Food Chem. 60, 10375-10397. https://doi.org/10.1021/jf302436u

Eglinton, G., Hamilton, R.J., 1967. Leaf epicuticular waxes. Science (80-. ). 156, 1322-1335. https://doi.org/10.1126/science.156.3780.1322

Eglinton, T.I., Eglinton, G., 2008. Molecular proxies for paleoclimatology. Earth Planet. Sci. Lett. 275, 1-16. https://doi.org/10.1016/j.epsl.2008.07.012

Erb, K.H., Kastner, T., Plutzar, C., Bais, A.L.S., Carvalhais, N., Fetzel, T., Gingrich, S., Haberl, H., Lauk, C., Niedertscheider, M., Pongratz, J., Thurner, M., Luyssaert, S., 2018. Unexpectedly large impact of forest management and grazing on global vegetation biomass. Nature 553, 73-76. https://doi.org/10.1038/nature25138

Euler, M., Schwarze, S., Siregar, H., Qaim, M., 2016. Oil Palm Expansion among Smallholder Farmers in Sumatra, Indonesia. J. Agric. Econ. 67, 658-676. https://doi.org/10.1111/1477-9552.12163

Faber, J., Quadros, A.F., Zimmer, M., 2018. A Space-For-Time approach to study the effects of increasing temperature on leaf litter decomposition under natural conditions. Soil Biol. Biochem. 123, 250-256. https://doi.org/10.1016/j.soilbio.2018.05.010

FAO, 2019. FAOSTAT Production Statistics [WWW Document]. Food Agric. Organ. United Nations, Rome. URL http://www.fao.org/faostat/en/?\#data/QC; accessed: 19.05.2021

FAO and UNEP, 2020. The State ofthe World's Forests 2020. Forests, biodiversity, and people. Rome. https://doi.org/https://doi.org/10.4060/ca8642en; accessed: 19.05.2021

Fearnside, P.M., 1997. Transmigration in Indonesia: Lessons from its environmental and social impacts. Environ. Manage. 21, 553-570. https://doi.org/10.1007/s002679900049 
Fontaine, S., Mariotti, A., Abbadie, L., 2003. The priming effect of organic matter: A question of microbial competition? Soil Biol. Biochem. 35, 837-843. https://doi.org/10.1016/S00380717(03)00123-8

Fujisaki, K., Chevallier, T., Chapuis-Lardy, L., Albrecht, A., Razafimbelo, T., Masse, D., Ndour, Y.B., Chotte, J.L., 2018. Soil carbon stock changes in tropical croplands are mainly driven by carbon inputs: A synthesis. Agric. Ecosyst. Environ. 259, 147-158. https://doi.org/10.1016/j.agee.2017.12.008

Gibson, L.; Lee, T. M.; Koh, L.P.; Brook, B.W.; Gardner, T.A.; Barlow, J.; Peres, C.A.; Bradshaw, C.J.A.; Laurance, W.F.; Lovejoy, T.E.; Sodhi, N.S., 2011. Primary forests are irreplaceable for sustaining tropical biodiversity. Nature 478, 378-381. https://doi.org/10.1038/nature10425

Gimsing, A.L., Szilas, C., Borggaard, O.K., 2007. Sorption of glyphosate and phosphate by variablecharge tropical soils from Tanzania. Geoderma 138, 127-132. https://doi.org/10.1016/j.geoderma.2006.11.001

Graf-Rosenfellner, M., Cierjacks, A., Kleinschmit, B., Lang, F., 2016. Soil formation and its implications for stabilization of soil organic matter in the riparian zone. Catena 139, 9-18. https://doi.org/10.1016/j.catena.2015.11.010

Grass, I., Kubitza, C., Krishna, V. V., Corre, M.D., Mußhoff, O., Pütz, P., Drescher, J., Rembold, K., Ariyanti, E.S., Barnes, A.D., Brinkmann, N., Brose, U., Brümmer, B., Buchori, D., Daniel, R., Darras, K.F.A., Faust, H., Fehrmann, L., Hein, J., Hennings, N., Hidayat, P., Hölscher, D., Jochum, M., Knohl, A., Kotowska, M.M., Krashevska, V., Kreft, H., Leuschner, C., Lobite, N.J.S., Panjaitan, R., Polle, A., Potapov, A.M., Purnama, E., Qaim, M., Röll, A., Scheu, S., Schneider, D., Tjoa, A., Tscharntke, T., Veldkamp, E., Wollni, M., 2020. Trade-offs between multifunctionality and profit in tropical smallholder landscapes. Nat. Commun. 11. https://doi.org/10.1038/s41467-020-15013-5

Guijarro, K.H., Aparicio, V., De Gerónimo, E., Castellote, M., Figuerola, E.L., Costa, J.L., Erijman, L., 2018. Soil microbial communities and glyphosate decay in soils with different herbicide application history. Sci. Total Environ. 634, 974-982. https://doi.org/10.1016/j.scitotenv.2018.03.393

Guillaume, T., 2015. Effects of rainforest transformation systems on carbon cycle and soil fertility. Dissertation. Georg-August-Universität Göttingen. https://ediss.unigoettingen.de/handle/11858/00-1735-0000-0028-8682-5, accessed: 05.05.2016

Guillaume, T., Damris, M., Kuzyakov, Y., 2015. Losses of soil carbon by converting tropical forest to plantations: Erosion and decomposition estimated by $\delta^{13} \mathrm{C}$. Glob. Chang. Biol. 21, 3548-3560. https://doi.org/10.1111/gcb.12907

Guillaume, T., Holtkamp, A.M., Damris, M., Brümmer, B., Kuzyakov, Y., 2016a. Soil degradation in oil palm and rubber plantations under land resource scarcity. Agric. Ecosyst. Environ. 232, 110 118. https://doi.org/10.1016/j.agee.2016.07.002

Guillaume, T., Kotowska, M.M., Hertel, D., Knohl, A., Krashevska, V., Murtilaksono, K., Scheu, S., Kuzyakov, Y., 2018. Carbon costs and benefits of Indonesian rainforest conversion to plantations. Nat. Commun. 9. https://doi.org/10.1038/s41467-018-04755-y

Guillaume, T., Maranguit, D., Murtilaksono, K., Kuzyakov, Y., 2016b. Sensitivity and resistance of soil fertility indicators to land-use changes: New concept and examples from conversion of Indonesian rainforest to plantations. Ecol. Indic. 67, 49-57. https://doi.org/10.1016/j.ecolind.2016.02.039

Haddad, N.M., Brudvig, L.A., Clobert, J., Davies, K.F., Gonzalez, A., Holt, R.D., Lovejoy, T.E., Sexton, J.O., Austin, M.P., Collins, C.D., Cook, W.M., Damschen, E.I., Ewers, R.M., Foster, B.L., Jenkins, C.N., King, A.J., Laurance, W.F., Levey, D.J., Margules, C.R., Melbourne, B.A., Nicholls, A.O., Orrock, J.L., Song, D.X., Townshend, J.R., 2015. Habitat fragmentation and its lasting impact on Earth's ecosystems. Sci. Adv. 1, 1-10. https://doi.org/10.1126/sciadv.1500052

Haney, R.L., Senseman, S.A., Hons, F.M., Zuberer, D.A., 2000. Effect of glyphosate on soil microbial activity and biomass. Weed Sci. 48, 89-93. https://doi.org/10.1614/00431745(2000)048[0089:eogosm]2.0.co;2 
Hansen, M. C.; Potapov, P.V.; Moorem R.; Hancher, M.; Turubanova, S.A.; Tyukavina, A.; Thau, D.; Stehman, S.V.; Goetz, S.J:; Loveland, T.R.; Kommareddy, A.; Egorov, A.; Chini, L.; Justice, C.O.; Townsend, J.R.G., 2013. High-Resolution Global Maps of. Science (80-. ). 342, 850-854. https://doi.org/10.1126/science.1244693

Harris, N.L., Brown, S., Hagen, S.C., Saatchi, S.S., Petrova, S., Salas, W., Hansen, M.C., Potapov, P. V., Lotsch, A., 2012. Baseline map of carbon emissions from deforestation in tropical regions. Science (80-. ). 336, 1573-1576. https://doi.org/10.1126/science.1217962

Hassler, S. K., B. Zimmermann, M. van Breugel, J. S. Hall, and H. Elsenbeer. 2011. Recovery of saturated hydraulic conductivity under secondary succession on former pasture in the humid tropics. Forest Ecology and Management 261(10):1634-1642. https://doi.org/10.1016/j.foreco.2010.06.031

Harwood, J.L.; Russel, N.J., 1984. Distribution of lipids, in: Lipids in Plants and Microbes. Springer, Dordrecht, pp. 35-70.

Heinrich, S., Dippold, M.A., Werner, C., Wiesenberg, G.L.B., Kuzyakov, Y., Glaser, B., 2015. Allocation of freshly assimilated carbon into primary and secondary metabolites after in situ ${ }^{13} \mathrm{C}$ pulse labelling of Norway spruce (Picea abies). Tree Physiol. 35, 1176-1191. https://doi.org/10.1093/treephys/tpv083

Hobbie, J.E., Hobbie, E.A., 2013. Microbes in nature are limited by carbon and energy: The starvingsurvival lifestyle in soil and consequences for estimating microbial rates. Front. Microbiol. 4, 1-11. https://doi.org/10.3389/fmicb.2013.00324

Hutchinson, J.J., Campbell, C.A., Desjardins, R.L., 2007. Some perspectives on carbon sequestration in agriculture. Agric. For. Meteorol. 142, 288-302. https://doi.org/10.1016/j.agrformet.2006.03.030

Jobbágy, E.G., Jackson, R.B., 2000. The vertical distribution of soil organic carbon and its relation to climate and vegetation. Ecol. Appl. 10, 423-436. https://doi.org/10.1890/10510761(2000)010[0423:TVDOSO]2.0.CO;2

Jonge, H. De, Jonge, L.W. De, 1999. pH influence on Gly Transport 39, 753-763.

Juo, A.S.R., Manu, A., 1996. Chemical dynamics in slash-and-burn agriculture. Agric. Ecosyst. Environ. 58, 49-60.

Kindler, R., Miltner, A., Richnow, H.H., Kästner, M., 2006. Fate of gram-negative bacterial biomass in soil - Mineralization and contribution to SOM. Soil Biol. Biochem. 38, 2860-2870. https://doi.org/10.1016/j.soilbio.2006.04.047

Kögel-Knabner, I., 2002. The macromolecular organic composition of plant and microbial residues as inputs to soil organic matter: Fourteen years on. Soil Biol. Biochem. 105, A3-A8. https://doi.org/10.1016/j.soilbio.2016.08.011

Kollattukudy, P.E., 1980. Cutin, Suberin, and Waxes, in: Lipids: Structure and Function. pp. 571-645. https://doi.org/10.1016/b978-0-12-675404-9.50024-2

Kongsager, R., Napier, J., Mertz, O., 2013. The carbon sequestration potential of tree crop plantations. Mitig. Adapt. Strateg. Glob. Chang. 18, 1197-1213. https://doi.org/10.1007/s11027-012-9417-z

Kotowska, M.M., Leuschner, C., Triadiati, T., Meriem, S., Hertel, D., 2015. Quantifying above- and belowground biomass carbon loss with forest conversion in tropical lowlands of Sumatra (Indonesia). Glob. Chang. Biol. 21, 3620-3634. https://doi.org/10.1111/gcb.12979

Krashevska, V., Klarner, B., Widyastuti, R., Maraun, M., Scheu, S., 2015. Impact of tropical lowland rainforest conversion into rubber and oil palm plantations on soil microbial communities. Biol. Fertil. Soils 51, 697-705. https://doi.org/10.1007/s00374-015-1021-4

Krashevska, V., Malysheva, E., Klarner, B., Mazei, Y., Maraun, M., Widyastuti, R., Scheu, S., 2018. Micro-decomposer communities and decomposition processes in tropical lowlands as affected by land use and litter type. Oecologia 187, 255-266. https://doi.org/10.1007/s00442-018-4103-9

Krüger, J.P., Leifeld, J., Alewell, C., 2014. Degradation changes stable carbon isotope depth profiles in palsa peatlands. Biogeosciences 11, 3369-3380. https://doi.org/10.5194/bg-11-3369-2014

Krull, E.S., Baldock, J.A., Skjemstad, J.O., 2003. Importance of mechanisms and processes of the stabilisation of soil organic matter for modelling carbon turnover. Funct. Plant Biol. 30, 207- 
222. https://doi.org/10.1071/FP02085

Kurniawan, S., Corre, M.D., Matson, A.L., Schulte-Bisping, H., Utami, S.R., Van Straaten, O., Veldkamp, E., 2018. Conversion of tropical forests to smallholder rubber and oil palm plantations impacts nutrient leaching losses and nutrient retention efficiency in highly weathered soils. Biogeosciences 15, 5131-5154. https://doi.org/10.5194/bg-15-5131-2018

Kuzyakov, Y., Bol, R., 2006. Sources and mechanisms of priming effect induced in two grassland soils amended with slurry and sugar. Soil Biol. Biochem. 38, 747-758. https://doi.org/10.1016/j.soilbio.2005.06.025

Kuzyakov, Y., Friedel, J.K., Stahr, K., 2000. Review of mechanisms and quantification of priming effects. Soil Biol. Biochem. 32, 1485-1498. https://doi.org/10.1016/S0038-0717(00)00084-5

Laclau, J.P., Ranger, J., de Moraes Gonçalves, J.L., Maquère, V., Krusche, A. V., M’Bou, A.T., Nouvellon, Y., Saint-André, L., Bouillet, J.P., de Cassia Piccolo, M., Deleporte, P., 2010. Biogeochemical cycles of nutrients in tropical Eucalyptus plantations. Main features shown by intensive monitoring in Congo and Brazil. For. Ecol. Manage. 259, 1771-1785. https://doi.org/10.1016/j.foreco.2009.06.010

Ladygina, N., Dedyukhina, E.G., Vainshtein, M.B., 2006. A review on microbial synthesis of hydrocarbons. Process Biochem. 41, 1001-1014. https://doi.org/10.1016/j.procbio.2005.12.007

Lal, R., 2003. Soil erosion and the global carbon budget. Environ. Int. 29, 437-450. https://doi.org/10.1016/S0160-4120(02)00192-7

Laumonier, Y., 1997. The Vegetation and Physiography of Sumatra. Springer Netherlands, Dordrecht. https://doi.org/10.1007/978-94-009-0031-8_1

Leblois, A., Damette, O., Wolfersberger, J., 2017. What has Driven Deforestation in Developing Countries Since the 2000s? Evidence from New Remote-Sensing Data. World Dev. 92, 82-102. https://doi.org/10.1016/j.worlddev.2016.11.012

Liang, C., Schimel, J.P., Jastrow, J.D., 2017. The importance of anabolism in microbial control over soil carbon storage. Nat. Microbiol. 2. https://doi.org/10.1038/nmicrobiol.2017.105

Lorenz, K., Lal, R., Preston, C.M., Nierop, K.G.J., 2007. Strengthening the soil organic carbon pool by increasing contributions from recalcitrant aliphatic bio(macro)molecules. Geoderma 142, 1-10. https://doi.org/10.1016/j.geoderma.2007.07.013

Ludwig, M., Achtenhagen, J., Miltner, A., Eckhardt, K.U., Leinweber, P., Emmerling, C., ThieleBruhn, S., 2015. Microbial contribution to SOM quantity and quality in density fractions of temperate arable soils. Soil Biol. Biochem. 81, 311-322. https://doi.org/10.1016/j.soilbio.2014.12.002

Mamy, L., Barriuso, E., Gabrielle, B., 2016. Glyphosate fate in soils when arriving in plant residues. Chemosphere 154, 425-433. https://doi.org/10.1016/j.chemosphere.2016.03.104

Margono, B.A., Potapov, P. V, Turubanova, S., Stolle, F., Hansen, M.C., 2014. Primary forest cover loss in indonesia over 2000-2012. Nat. Clim. Chang. https://doi.org/10.1038/nclimate2277

Marschner, P., Kandeler, E., Marschner, B., 2003. Structure and function of the soil microbial community in a long-term fertilizer experiment. Soil Biol. Biochem. 35, 453-461. https://doi.org/10.1016/S0038-0717(02)00297-3

McCormick, J.F., 1978. A summary ofthe national riparian symposium., in: Johnson, R.R. McCormick, J.F. (Ed.), Strategies for Protection and Management of Floodplain Wetlands and Other Riparian Ecosystems. Washington D.C., pp. 362-363.

Moore, S., Evans, C.D., Page, S.E., Garnett, M.H., Jones, T.G., Freeman, C., Hooijer, A., Wiltshire, A.J., Limin, S.H., Gauci, V., 2013. Deep instability of deforested tropical peatlands revealed by fluvial organic carbon fluxes. Nature 493, 660-663. https://doi.org/10.1038/nature11818

Munira, S., Farenhorst, A., Akinremi, W., 2018. Phosphate and glyphosate sorption in soils following long-term phosphate applications. Geoderma 313, 146-153. https://doi.org/10.1016/j.geoderma.2017.10.030

Murphy, B.W., 2015. Impact of soil organic matter on soil properties - A review with emphasis on Australian soils. Soil Res. 53, 605-635. https://doi.org/10.1071/SR14246

Nguyen, D.B., Rose, M.T., Rose, T.J., Morris, S.G., van Zwieten, L., 2016. Impact of glyphosate on soil 
microbial biomass and respiration: A meta-analysis. Soil Biol. Biochem. 92, 50-57. https://doi.org/10.1016/j.soilbio.2015.09.014

Nguyen Tu, T.T., Egasse, C., Zeller, B., Bardoux, G., Biron, P., Ponge, J.F., David, B., Derenne, S., 2011. Early degradation of plant alkanes in soils: A litterbag experiment using 13C-labelled leaves. Soil Biol. Biochem. 43, 2222-2228. https://doi.org/10.1016/j.soilbio.2011.07.009

O Duke, S., Powles, S.B., 2008. Mini-review Glyphosate: a once-in-a-century herbicide. Pest Manag. Sci. 64, 319-325. https://doi.org/10.1002/ps.1518

Osipov, G.A., Turova, E.S., 1997. Studying species composition of microbial communities with the use of gas chromatography-mass spectrometry: Microbial community of kaolin. FEMS Microbiol. Rev. 20, 437-446. https://doi.org/10.1016/S0168-6445(97)00048-X

Pachepsky, Y., and Y. Park. 2015. Saturated hydraulic conductivity of US soils grouped according to textural class and bulk density. Soil Science Society of America Journal 79(4):1094-1100. https://doi.org/10.2136/sssaj2015.02.0067

Pendrill, F., Persson, U.M., Godar, J., Kastner, T., Moran, D., Schmidt, S., Wood, R., 2019. Agricultural and forestry trade drives large share of tropical deforestation emissions. Glob. Environ. Chang. 56, 1-10. https://doi.org/10.1016/j.gloenvcha.2019.03.002

Pickett, S.T.A., 1989. Space-for-Time Substitution as an Alternative to Long-Term Studies, in: Likens, G.E. (Ed.), Long-Term Studies in Ecology. Approaches and Alternatives. Springer, New York, NY, New York, pp. 110-135.

Pollard, M., Beisson, F., Li, Y., Ohlrogge, J.B., 2008. Building lipid barriers: biosynthesis of cutin and suberin. Trends Plant Sci. 13, 236-246. https://doi.org/10.1016/j.tplants.2008.03.003

Pollegioni, L., Schonbrunn, E., Siehl, D., 2012. Glyphosate; Herbicide Resistance; Herbicide Tolerance; Protein Engineering; Transgenic Crops 278, 2753-2766. https://doi.org/10.1111/j.1742-4658.2011.08214.x.Molecular

Powers, J.S., 2004. Changes in soil carbon and nitrogen after contrasting land-use transitions in northeastern Costa Rica. Ecosystems 7, 134-146. https://doi.org/10.1007/s10021-003-0123-2

Prananto, J.A., Minasny, B., Comeau, L.P., Rudiyanto, R., Grace, P., 2020. Drainage increases CO2 and $\mathrm{N} 2 \mathrm{O}$ emissions from tropical peat soils. Glob. Chang. Biol. 26, 4583-4600. https://doi.org/10.1111/gcb.15147

Pransiska, Y., Triadiati, T., Tjitrosoedirjo, S., Hertel, D., Kotowska, M.M., 2016. Forest conversion impacts on the fine and coarse root system, and soil organic matter in tropical lowlands of Sumatera (Indonesia). For. Ecol. Manage. https://doi.org/10.1016/j.foreco.2016.07.038

Pribyl, D.W., 2010. A critical review of the conventional SOC to SOM conversion factor. Geoderma 156, 75-83. https://doi.org/10.1016/j.geoderma.2010.02.003

Rahman, N., De Neergaard, A., Magid, J., Van De Ven, G.W.J., Giller, K.E., Bruun, T.B., 2018. Changes in soil organic carbon stocks after conversion from forest to oil palm plantations in Malaysian Borneo. Environ. Res. Lett. 13. https://doi.org/10.1088/1748-9326/aade0f

Ramsar Convention Secretariat, 2016. An Introduction to the Ramsar Convention on Wetlands: Handbook 1 - International Cooperation on Wetlands. 5th Ed. 108.

Reeves, D.W., 1997. The role of soil organic matter in maintaining soil quality in continuous cropping systems. Soil Tillage Res. 43, 131-167. https://doi.org/10.1016/S0167-1987(97)00038-X

Rembold, K., Mangopo, H., Tjitrosoedirdjo, S.S., Kreft, H., 2017. Plant diversity, forest dependency, and alien plant invasions in tropical agricultural landscapes. Biol. Conserv. 213, 234-242. https://doi.org/10.1016/j.biocon.2017.07.020

Rieger, I., Lang, F., Kowarik, I., Cierjacks, A., 2014. The interplay of sedimentation and carbon accretion in riparian forests. Geomorphology 214, 157-167. https://doi.org/10.1016/j.geomorph.2014.01.023

Ritchie, N.J., Schutter, M.E., Dick, R.P., Myrold, D.D., 2000. Use of length heterogeneity PCR and fatty acid methyl ester profiles to characterize microbial communities in soil. Appl. Environ. Microbiol. 66, 1668-1675. https://doi.org/10.1128/AEM.66.4.1668-1675.2000

Rudolf, K., 2020. Policies and Management Practices for Sustainable Oil Palm - Evidence from Indonesia 223. Dissertation. Georg-August-Universität Göttingen. https://ediss.uni- 
goettingen.de/handle/21.11130/00-1735-0000-0005-1425-B, accessed: 15.03.2021

Rüegg, J., Quezada, J.C., Santonja, M., Ghazoul, J., Kuzyakov, Y., Buttler, A., Guillaume, T., 2019. Drivers of soil carbon stabilization in oil palm plantations. L. Degrad. Dev. 30, 1904-1915. https://doi.org/10.1002/ldr.3380

Scharlemann, J.P.W., Tanner, E.V.J., Hiederer, R., Kapos, V., Pw, J., Tanner, E.V.J., Hiederer, R., Kapos, V., 2014. Global soil carbon : understanding and managing the largest terrestrial carbon pool. Carbon Manag. 5, 81-91. https://doi.org/10.4155/cmt.13.77

Schweigert, M., Herrmann, S., Miltner, A., Fester, T., Kästner, M., 2015. Fate of ectomycorrhizal fungal biomass in a soil bioreactor system and its contribution to soil organic matter formation. Soil Biol. Biochem. 88, 120-127. https://doi.org/10.1016/j.soilbio.2015.05.012

Shakhmatova, E.Y., Korsunov, V.M., 2008. Buried humus horizons of flooded soils of the Selenga river delta. Geogr. Nat. Resour. 29, 338-342. https://doi.org/10.1016/j.gnr.2008.10.012

Six, J.; Feller, C.; Denef, K.; Ogle, S.; de Moraes Sa, J.C.; Albrecht, A., 2002. Soil organic matter, biota and aggregation in temperate and tropical soils - Effect of no-tillage. Agronomie 2223, 755-775. https://doi.org/10.1051/agro

Smith, D.R., Townsend, T.J., Choy, A.W.K., Hardy, I.C.W., Sjögersten, S., 2012. Short-term soil carbon sink potential of oil palm plantations. GCB Bioenergy 4, 588-596. https://doi.org/10.1111/j.17571707.2012.01168.x

Soong, J.L., Fuchslueger, L., Marañon-Jimenez, S., Torn, M.S., Janssens, I.A., Penuelas, J., Richter, A., 2020. Microbial carbon limitation: The need for integrating microorganisms into our understanding of ecosystem carbon cycling. Glob. Chang. Biol. 26, 1953-1961. https://doi.org/10.1111/gcb.14962

Straaten, O. van, Corre, M.D., Wolf, K., Tchienkoua, M., Cuellar, E., Matthews, R.B., Veldkamp, E., 2015. Conversion of lowland tropical forests to tree cash crop plantations loses up to one-half of stored soil organic carbon. Proc. Natl. Acad. Sci. 112, 9956-9960. https://doi.org/10.1073/PNAS.1504628112

Tao, H.H., Donough, C., Hoffmann, M.P., Lim, Y.L., Hendra, S., Rahmadsyah, Abdurrohim, G., Indrasuara, K., Lubis, A., Dolong, T., Oberthür, T., 2017. Effects of best management practices on dry matter production and fruit production efficiency of oil palm. Eur. J. Agron. 90, 209215. https://doi.org/10.1016/j.eja.2017.07.008

Tao, H.H., Slade, E.M., Willis, K.J., Caliman, J.P., Snaddon, J.L., 2016. Effects of soil management practices on soil fauna feeding activity in an Indonesian oil palm plantation. Agric. Ecosyst. Environ. 218, 133-140. https://doi.org/10.1016/j.agee.2015.11.012

Tsujino, R., Yumoto, T., Kitamura, S., Djamaluddin, I., Darnaedi, D., 2016. History of forest loss and degradation in Indonesia. Land use policy 57, 335-347. https://doi.org/10.1016/j.landusepol.2016.05.034

Van Bruggen, A.H.C., He, M.M., Shin, K., Mai, V., Jeong, K.C., Finckh, M.R., Morris, J.G., 2018. Environmental and health effects of the herbicide glyphosate. Sci. Total Environ. 616-617, 255268. https://doi.org/10.1016/j.scitotenv.2017.10.309

Wantzen, K.M. Yule Catherine M., Trockner Klement, J.W.J., 2008. Riparian Wetlands of Tropical Streams, in: Dudgeon, D. (Ed.), Tropical Stream Ecology. Elsevier Inc. Academic Press, pp. 3035-3044. https://doi.org/10.1016/B978-008045405-4.00352-9

Wiesenberg, G.L.B., Dorodnikov, M., Kuzyakov, Y., 2010. Source determination of lipids in bulk soil and soil density fractions after four years of wheat cropping. Geoderma 156, 267-277. https://doi.org/10.1016/j.geoderma.2010.02.026

Xu, X., Luo, Y., Zhou, J., 2012. Carbon quality and the temperature sensitivity of soil organic carbon decomposition in a tallgrass prairie. Soil Biol. Biochem. 50, 142-148. https://doi.org/10.1016/j.soilbio.2012.03.007

Zabaloy, M.C., Carné, I., Viassolo, R., Gómez, M.A., Gomez, E., 2016. Soil ecotoxicity assessment of glyphosate use under field conditions: Microbial activity and community structure of Eubacteria and ammonia-oxidising bacteria. Pest Manag. Sci. 72, 684-691. https://doi.org/10.1002/ps.4037 
Zang, H., Blagodatskaya, E., Wen, Y., Xu, X., Dyckmans, J., Kuzyakov, Y., 2018. Carbon sequestration and turnover in soil under the energy crop Miscanthus: repeated $13 \mathrm{C}$ natural abundance approach and literature synthesis. GCB Bioenergy 10, 262-271. https://doi.org/10.1111/gcbb.12485

Zech, M., Buggle, B., Leiber, K., Marković, S., Glaser, B., Hambach, U., Huwe, B., Stevens, T., Sümegi, P., Wiesenberg, G., Zöller, L., 2009. Reconstructing Quaternary vegetation history in the Carpathian Basin, SE-Europe, using n-alkane biomarkers as molecular fossils: Problems and possible solutions, potential and limitations. E\&amp;G Quat. Sci. J. 58, 148-155. https://doi.org/10.3285/eg.58.2.03

Zech, M., Rass, S., Buggle, B., Löscher, M., Zöller, L., 2012. Reconstruction of the late Quaternary paleoenvironments of the Nussloch loess paleosol sequence, Germany, using n-alkane biomarkers. Quat. Res. (United States) 78, 226-235. https://doi.org/10.1016/j.yqres.2012.05.006

Zhou, M., Liu, C., Wang, J., Meng, Q., Yuan, Y., Ma, X., Liu, X., Zhu, Y., Ding, G., Zhang, J., Zeng, X., Du, W., 2020. Soil aggregates stability and storage of soil organic carbon respond to cropping systems on Black Soils of Northeast China. Sci. Rep. 10, 1-13. https://doi.org/10.1038/s41598019-57193-1

Zhu, X., Jackson, R.D., DeLucia, E.H., Tiedje, J.M., Liang, C., 2020. The soil microbial carbon pump: From conceptual insights to empirical assessments. Glob. Chang. Biol. 26, 6032-6039. https://doi.org/10.1111/gcb.15319 


\section{Publications and Manuscripts}

\subsection{Flooding and land use change in Jambi Province, Sumatra: integrating local knowledge and scientific inquiry}

published in: Ecology and Society (2020), 25(3):14. https://doi.org/10.5751/ES-11678-250314

Jennifer Merten* , Christian Stiegler, Nina Hennings, Alexander Röll , Herdhata Agusta , Michaela A. Dippold Lutz Fehrmann, Dodo Gunawan, Dirk Hölscher, Alexander Knohl, Johanna Kückes, Fenna Otten, Delphine C. Zemp and Heiko Faust

${ }^{1}$ University of Goettingen, Human Geography, Germany,

${ }^{2}$ Humboldt-Universität zu Berlin, Integrative Research Institute on Transformations of Human-Environment Systems (IRI THESys), Germany,

${ }^{3}$ University of Goettingen, Bioclimatology, Germany,

${ }^{4}$ University of Goettingen, Soil Science of Temperate Ecosystems, Germany,

${ }^{5}$ University of Goettingen, Forest Inventory and Remote Sensing, Germany,

University of Goettingen, Tropical Silviculture and Forest Ecology, Germany,

${ }^{7}$ Bogor Agricultural University, Agronomy and Horticulture, Indonesia,

${ }^{8}$ Bogor Agricultural University, Surfactant and Bioenergy Research Center (SBRC), Indonesia, ${ }^{9}$ University of Goettingen, Biogeochemistry of Agroecosystems, Germany,

${ }^{10}$ University of Goettingen, Centre of Biodiversity and Sustainable Land Use (CBL), Germany,

${ }^{11}$ Agency for Meteorology, Climatology and Geophysics, Center of Climate Change Information, Jakarta, Indonesia,

${ }^{12}$ University of Goettingen, Biodiversity, Macroecology and Biogeography, Germany

${ }^{*}$ Corresponding author: Jennifer Merten 


\subsubsection{ABSTRACT}

The rapid expansion of rubber and oil palm plantations in Jambi Province, Sumatra, Indonesia, is associated with largescale deforestation and the impairment of many ecosystem services. According to villagers' observations, this land use change has, together with climate change, led to an increase in the magnitude and frequency of river flood events, which constrain village and plantation development. Based on this empirical societal problem, we investigate whether we can find measurable indications for the presumed linkages between land use change, climate change, and changing flooding regimes. We follow an explorative, bottom-up research approach that builds on a review of multidisciplinary datasets, integrating local ecological knowledge with scientific measurements from soil science, climatology, hydrology, and remote sensing. We found that water levels of one of the largest rivers in Jambi Province, the Tembesi, have increased significantly during the last two decades. Data of local and regional meteorological stations show that alterations in rainfall patterns may only partly explain these changes. Rather, increased soil densities and decreased water infiltration rates in monoculture plantations suggest an increase in surface runoff following forest conversion. Moreover, additional interview data reveal that an increasing encroachment of wetlands in Jambi Province may contribute to changes in local flooding regimes, as the construction of drainage and flood control infrastructure redistributes floodwater at the local scale. We conclude that changing flooding regimes are the result of multiple interacting social-ecological processes associated with the expansion of rubber and oil palm plantations in Jambi Province. Although ecohydrological changes are likely to contribute to an increase of flood occurrence, their social impacts are increasingly mediated through flood control infrastructure on industrial oil palm plantations.

Keywords: ecohydrology; flooding; global change; Indonesia; interdisciplinary analysis; land use conversion; local ecological knowledge; oil palm; rubber 


\subsubsection{INTRODUCTION}

In the past, flooding occurred rarely. ... Back then, most people didn't plant oil palm, didn't plant rubber.... It started, because the forest is already gone. That's why nowadays flooding occurs so often. ... For annual crops, if flooding occurs more often, that's a problem.... [Sometimes] when the farmers had just planted the seedlings, then suddenly flooding occurred.

Rubber farmer, Jambi, Sumatra, Indonesia

In Southeast Asia, large areas of lowland forests have been converted to oil palm, rubber, and pulp wood plantations over the last decades (Hansen et al. 2013, Margono et al. 2014, Clough et al. 2016). For example, in 2015, oil palm plantations in Malaysia and Indonesia covered an area of 17 million ha (Chong et al. 2017). Such intense land use change is often followed by an impairment of ecohydrological functions (Bruijnzeel 2004, Bradshaw et al. 2007, Ellison et al. 2017). Several studies have recently started to connect the expansion of rubber and oil palm monoculture plantation systems with increases in the frequency and intensity of flooding.

The existing studies build on a variety of methodological approaches. Hydrological measurements showed that oil palm monoculture plantations may have low soil water infiltration rates (Tarigan et al. 2018) as a consequence of severe soil degradation and erosion (Guillaume et al. 2015, 2016). Particularly in combination with low evapotranspiration rates of young oil palm plantations this may increase surface run-off and the risk of flooding in oil palm dominated landscapes (Manoli et al. 2018, Tarigan et al. 2018). These findings also correspond with a time-series analysis of streamflow data that found evidence for increasing streamflow through upstream land use conversion to rubber and oil palm plantations (Adnan and Atkinson 2011). Other approaches have built on spatial analyses and econometric modeling. For example, Tan-Soo et al. (2016) and Wells et al. (2016) found rubber and oil palm plantations to be spatially associated with reports of increasing flooding occurrence in Malaysia and Indonesia. Finally, a number of studies conducting qualitative social research present interview data from villagers across Indonesia who associated land use change, toward monoculture plantations, with increasing flood occurrence (Obidzinski et al. 2012, Larsen et al. 2014, Kelley and Prabowo 2019). 
Such a linkage between the expansion of plantations and flooding was also observed by villagers in our study area in Jambi Province, Sumatra, as pointed out in the above quote from a smallholder farmer. In times of rapid land use change for global cash crop production, understanding such processes is of great relevance for the affected communities. Although the above-mentioned studies provide some evidence of changing flooding regimes due to plantation expansion, most of them present compartmentalized insights from single disciplines. A substantial gap in knowledge about the multiplicity of causal processes between land use change, climate change, and river water levels remains in our study region and beyond.

Establishing the linkage between land use change and flooding has been a long and contested endeavor among natural as well as social scientists (Calder and Aylward 2006, Bradshaw et al. 2007, van Dijk et al. 2009, Lele 2009). In public discourses, deforestation is often linked to an increase in the frequency and intensity of flooding. In fact, tree and forest removal is well known for raising the likelihood of floods, as decreasing evapotranspiration rates and decreasing water infiltration increase local surface runoff (Ellison et al. 2017). However, after deforestation, such processes may be reversed. Water infiltration rates may recover and evapotranspiration rates by planted tree species may then be as high as those of natural forests (Bruijnzeel 2004). Natural scientists have further cautioned that linkages between land use change and flooding regimes often depend upon the interaction of multiple, site-specific ecohydrological processes, including local climate change (Bradshaw et al. 2007, Alila et al. 2009, Locatelli and Vignola 2009, van Dijk et al. 2009, Tran et al. 2010, Pattison and Lane 2012). Social scientists, for their part, have warned that a generalization of the forest-flood linkage may result in policies with adverse social consequences, e.g., upstream forest dwellers being restricted in their land use activities and falsely blamed for causing downstream flooding (Saberwal 1998, Calder and Aylward 2006, Hofer and Messerli 2006). Moreover, they have pointed out that studies within the natural sciences often ignore the social and technical context that mediates flood impacts as well as response and feedback processes (Lele 2009, Di Baldassare et al. 2014).

Integrating local ecological knowledge into scientific analysis can address some of the above-mentioned uncertainties and risks when studying complex social-ecological phenomena (Pierotti and Wildcat 2000, Fabricius et al. 2006, Stringer and Reed 2007, Tengö 
et al. 2014, Leimona et al. 2015, Días et al. 2018). Such an integration of different knowledge sources may also enable research outcomes to be socially and practically more relevant in the local social context and is considered an important step toward democratizing explanations of environmental change (Forsyth 2003).

In this paper we aim to provide an integrated analysis of linkages between land use change, climate change, and flooding regimes by combining qualitative interview data on local ecological knowledge with scientific measurements. We examined multidisciplinary datasets to identify potential social-ecological processes that could explain the villagers' observations of increases in flood frequency and intensity following forest conversion in the Tembesi watershed in Jambi Province (Sumatra, Indonesia).

Our research objectives are the following: building on qualitative interviews, we (1) review villagers' observations of changes in patterns and intensity of flood events as well as their evaluations of changing environmental processes. We then (2) test whether the reported changes in flooding regimes are mirrored in available stream flow data from the Tembesi River. Building on the villagers' evaluations of the potential causes for changing flooding regimes, we test whether changes in climate and/or in land use can provide explanations for the observed changes. Therefore, we (3) analyze local precipitation patterns for changes over the last decades, and (4) compare hydraulic soil properties in different land use systems. More specifically, we quantify land use change in the Tembesi River watershed (1990-2013) and assess whether soil bulk densities (as an indicator of soil compaction), water infiltration capacities, and groundwater levels of oil palm and rubber plantations differ from forests and less intensively managed reference systems. Finally, based on villagers' specific concerns for land use change in wetland areas, we (5) investigate whether forest conversion in wetland areas has further contributed to an alteration of flooding regimes. To this aim, we analyze the land use history as well as land use characteristics of wetland areas, building on land use data (1990-2013) as well as on a comparison of qualitative case study data within the Tembesi watershed.

Finally, we integrate these multiple knowledge sources by discussing convergences, complementarities, and divergences among datasets. Although our study design was not a priori designed to answer questions related to flooding specifically, we show that an a posteriori analysis of different knowledge sources can be an important tool for 
interdisciplinary research. It can also provide a more complete analysis of the complex linkages between land use change and flooding.

\subsubsection{CONCEPTUAL FRAMEWORK}

Our research approach builds on the tradition of critical realist approaches in political ecology and sustainability sciences. These studies emphasize the need for problem-driven, bottom-up research approaches that integrate different knowledge sources to find locally framed explanations of environmental problems (Forsyth 2003, Walters and Vayda 2009, Lele and Kurien 2011, Thorén and Persson 2013, Ribot 2014).

Studies on flooding and flood impacts in the context of land use change are often dominated by accounts from the natural sciences. Changes in flooding regimes are mainly derived from direct ground-based measurements using water level or discharge data from flood gauges (e.g., MDID 1989, Yusop et al. 2007, Adnan and Atkinson 2011), or modeling exercises. Model inputs are typically based on direct field measurements of the different components of the hydrological cycle, such as soil surface runoff, infiltration rates, throughfall, or evapotranspiration rates (e.g., Manoli et al. 2018, Tarigan et al. 2018). Precipitation quantities are either obtained from satellite-derived precipitation and cloud cover estimates (Maggioni and Massari 2018), or based on combined field and satellite measurements (Kwak 2017). In recent years, satellite imagery has become a widely used tool for monitoring flood events on a large scale. However, optical-based satellite imagery has its limitations because of cloud cover, especially in the tropics (Ahamed and Bolten 2017, Ban et al. 2017, Adam et al. 2018, Notti et al. 2018). Typical indicators for changing flooding regimes include the number of days with extreme water levels or peak flows, average water level rise as an indicator for flash floods, average seasonal water levels, or shifts in seasonal water levels (Dang et al. 2011, Wang et al. 2015).

These approaches, however, have a number of limitations with regard to data availability and the integration of the human dimension. In the study of flooding regimes, local people's ecological knowledge may thus fruitfully complement scientific measurements. Local ecological knowledge (sometimes also referred to as traditional ecological knowledge) comprises three components of knowledge: observational knowledge, knowledge acquired through practical experience, and knowledge in the form of people's beliefs (Berkes et al. 2000). Such knowledge is acquired through personal empirical observation and 
interpretation of local ecosystems, and enriched and validated through exchange with other farmers and villagers (Berkes et al. 2000, Usher 2000, Houde 2007).

In particular, the integration of observational and practical local ecological knowledge may provide several benefits for establishing a link between land use change and flooding regimes. First, local ecological knowledge provides fine-grained information about ecosystems in areas where little scientific knowledge exists, such as rural Sumatra (Fabricius et al. 2006). A typical problem of scientific measurements is that field measurements are often only available at plot scale. On the other hand, modeling exercises conducted at larger scales often provide little information about factual changes in flooding regimes, e.g., at the village level. Integrating people's knowledge might also be useful for detecting environmental changes that are not immediately apparent in short-term scientific measurements as local people get to observe things more often, over longer periods, and in a wider variety of places (Usher 2000). Thereby it might draw attention to environmental change that otherwise would possibly not be studied. For example, Wells et al. (2016) integrated interview data with newspaper reports of flooding and watershed characteristics to show that flooding is far more widespread than reported in government assessments. Moreover, local ecological knowledge is considered to be holistic in nature, compared to scientific studies that are often compartmentalized (Pierotti and Wildcat 2000, Fabricius et al. 2006, Aikenhead and Ogawa 2007). Integrating local ecological knowledge in the study of land use change and flooding may thus enable more open research approaches, which could better account for multiple and interacting processes in the generation of flood events.

Second, both field measurements and modeling exercises often fail to adequately incorporate the human dimension of the problem, both with regard to defining what constitutes a problematic change in flooding as well as with regard to potential human influences on water flows (Lele 2009, Di Baldassare et al. 2014, Langill and Abizaid 2020). Lele and Kurien (2011) thus call for a shift from theory-driven to problem-driven, bottomup research, to avoid research questions that are only determined by what the researcher is trained in. For example, by questioning what actually constitutes a "bad flood," Langill and Abizaid (2020) showed that studies of extreme floods within the natural sciences typically focused on unusually high floods. In their study, they showed that for a floodplain 
community in the Peruvian Amazon the timing and duration of flooding were in fact the most salient features of problematic floods. Existing studies connecting land use change in Indonesia and Malaysia to changing flooding regimes either investigated streamflow fluctuations independent of human evaluation (Adnan and Atkinson 2011) or looked at the number of flood events reported by newspapers and government assessments (Tan-Soo et al. 2016, Wells et al. 2016).

Integrating local ecological knowledge into the study of land use change and flooding may also help to draw attention to the social and technical context that mediates flood impacts. This integration may further contribute to an understanding of how changing flooding regimes may trigger people's response and feedback processes that shape water flows in turn (Lele 2009, Di Baldassare et al. 2014). For instance, Kelley and Prabowo (2019) use oral histories to reveal social transformation processes set in motion by changing flooding regimes. These transformation processes were shown to increase the people's systemic vulnerability to flooding as well as producing feedbacks of altering river flows.

Although multiple opportunities for integrating local knowledge and scientific measurements exist, the pitfalls of integration have also been discussed at length and, at times, in a controversial manner (Klubnikin et al. 2000, Pierotti and Wildcat 2000, Moller et al. 2004, Bohensky and Maru 2011, Persson et al. 2018). Similar to the integration of methods from qualitative social science and quantitative natural science, it has been pointed out that ontological and epistemological differences between knowledge sources may hinder output-oriented knowledge integration (Nadasdy 1999, Krüger et al. 2016, Thorén and Stahlhammer 2018). In particular, in-depth confrontations between different ontological understandings and assumptions, or critical engagements with other approaches for establishing scientific quality and validity of methods, are often limited by time constraints. Despite such concerns, we argue that more pragmatic approaches that foster interdisciplinary research are both possible and valuable. An important condition for overcoming challenges of integration is a common framing of the research problem. Several scholars have therefore recommended taking an empirical societal problem as a starting point of analysis, i.e., observations of increasing flood occurrence (Walters and Vayda 2009, Lele and Kurien 2011, Thorén and Persson 2013). Explanations from different disciplines and knowledge sources may then be reconciled by seeing each as partial, context-specific, 
and potentially fallible, but acknowledging that the combination of different sources may provide better understandings of environmental problems (Yeung 1997, Forsyth 2003, Lele and Kurien 2011).

\subsubsection{STUDY REGION AND METHODS}

Our study region, Jambi Province, lies in the eastern lowlands of Sumatra, Indonesia. In Jambi Province, 7942 km² of forest were cleared between 1990 and 2013, which corresponds to $35.2 \%$ of the 1990 forest area (Melati 2017). Most land use changes have taken place in the lowlands of Jambi Province, which today are dominated by monoculture rubber (Hevea brasiliensis) and oil palm (Elaeis guineensis Jacq.) plantations. Monoculture rubber plantations have been developed in Jambi Province since the Dutch colonial times (Feintrenie and Levang 2009); oil palm cultivation started in the mid-1980s and has expanded to almost $9000 \mathrm{~km}^{2}$ (18\% of the province's territory) in 2017 (BPS Indonesia 2018).

The lowland rivers of Jambi Province show strong seasonal fluctuations between the dry and the wet season. Consequently, large areas in the province's lowlands are inundated during the rainy season. In the Batanghari watershed $\left(44,595 \mathrm{~km}^{2}\right)$, the largest watershed in Jambi Province, $2282 \mathrm{~km}^{2}$ of land across 222 villages is affected by regular flood events (Minister of Public Works 2012).

Our paper presents findings with a focus on the lowlands of the Tembesi watershed, the largest subwatershed of the Batanghari $\left(12,819 \mathrm{~km}^{2}\right)$. This focus was chosen because of the dynamic land use change in this area, the number of people affected by flooding, as well as data availability. The watershed's lowlands cover large wetland areas, which include peatland areas of around $440 \mathrm{~km}^{2}$ (see Figure 2.1-1; Wahyunto and Subagjo 2003, Biagioni et al. 2015). Today, land use in the lowland areas of the Tembesi is dominated by agriculture, mainly oil palm and rubber plantations that account for $52 \%$ of the watershed's area (Figure 2.1-1; Melati 2017). The climate in the watershed's lowlands is tropical humid (annual average air temperature of $26.5^{\circ} \mathrm{C}$, annual precipitation of $2235 \mathrm{~mm}^{-1} \mathrm{ear}^{-1}$ ) with a wet season from October to May (Sulthan Thaha meteorological station, as cited in Drescher et al. 2016). According to data published in local newspapers, the typical seasonal fluctuations of the Tembesi water levels in the watershed's lowlands vary between 5 and $11 \mathrm{~m}$ (Anton 2017, Saputra 2017). All data analyzed for this study was obtained within the EFForTS collaborative research center (https://www.uni-goettingen.de/en/310995.html). 


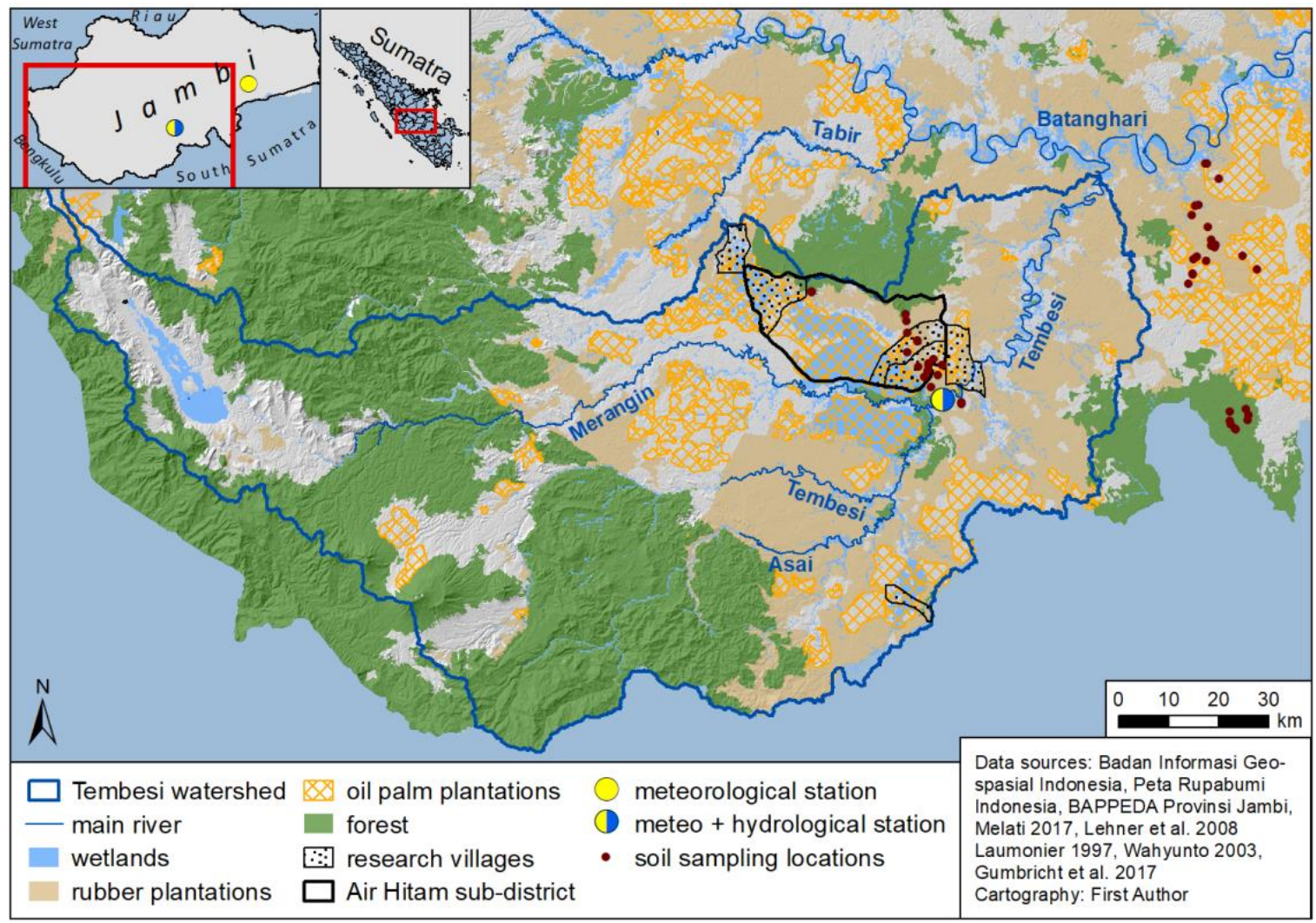

Figure 2.1-1: Study region of the Tembesi watershed in Jambi Province, Sumatra, Indonesia.

\subsubsection{Qualitative interview data}

Our analysis builds on two different sets of qualitative interview data obtained from semistructured and informal interviews (total number of interviews $=91$; Bernard 2011). All interviews were conducted during long-term (2-6 months) field stays in Jambi Province between 2012 and 2017. Interviews were conducted in English and Indonesian with the help of local assistants. Detailed notes and memos were written down during or shortly after the interviews. In addition, audio-recorded interviews were transcribed in Indonesian. All interview notes as well as excerpts from transcripts were coded for content (Mayring 2000) using MAXQDA (V. 11) software.

\section{Local ecological knowledge on changing flooding regimes}

Interviews of the first dataset were mainly conducted in the subdistrict Air Hitam (Figure 2.1-1). In this subdistrict, three villages were chosen along an upstream-downstream continuum of the eponymous Air Hitam River. In this subdistrict, interview partners from 33 different households were interviewed. Interview partners were chosen according to snowball and purposive sampling methods (Flick 2016). Purposively selected interview 
partners included village government representatives, heads of farmer groups, village elders, and villagers who were directly affected by flood events, either on their housing plot or on their plantations. In addition to the households in the Air Hitam subdistrict, eight households, who own plantations in riparian areas that were also sampled for soil property analyses within the frame of this study, were purposively selected for interviews. Several of the interview partners were interviewed repeatedly during consecutive field visits, combining both formal and informal interview situations, and often involving family members or friends present during the interview situation (total number of interview situations $n=69$ ). The interviews focused on interrogating people's observations of changes in local flooding regimes, their individual evaluations of possible causal relations and the implications for the individual households.

\section{Local knowledge on land use history and management of wetlands}

Because of the interview partners' specific concern about land use change in wetland areas, an analysis of the second dataset aimed to explore the specific land use characteristics of wetland areas in the Tembesi watershed. Therefore, we compared land use history and management of wetland areas across six villages, the territories of which include vast wetland areas. In addition to the three villages in the Air Hitam subdistrict, our case study comparison comprised three further villages within the lowlands of the Tembesi watershed. Interviews conducted in these villages included data from former investigations within the EFForTS research project (Kunz 2016, Rödel 2018) that were made available for this study (additional number of interviews $n=22$ ). We define wetland areas as areas where water covers the soil or is near the surface of the soil either permanently or temporarily (Ramsar Convention Secretariat 2016). This includes riparian floodplains, swamps, as well as peatlands.

The presence of a foreign researcher most certainly influences the way interview partners recount a certain topic, e.g., by providing an answer they expect will please the researcher (Berger 2015). We aimed to reduce such response biases through conducting long-term qualitative research with repeated visits to the studied villages. Qualitative interview techniques were chosen as a method because they allow for bottom-up and in-depth analyses of people's evaluation of local environmental change. Contrary to predefined questionnaires, the use of open-ended questions and a more natural and spontaneous 
course of conversation allows researchers to create trusting and less formal interview situations. These are helpful for avoiding response biases because they allow the researcher to encourage interview partners to recount environmental changes on their own initiative. They further provide room for more detailed descriptions of environmental changes and reveal insights into the importance of flooding for people's daily life. Information obtained during interviews was then cross-checked in subsequent interviews with interview partners from different social groups. Finally, interview data was triangulated with participative observation, including several visits to villagers' plantations and different river sections.

\subsubsection{Quantitative scientific measurements}

\section{River water level}

The water level of the Tembesi River was measured at Pauh hydrological station $\left(02^{\circ} 08^{\prime} 55^{\prime \prime}\right.$ S, $102^{\circ} 48^{\prime} 22^{\prime \prime}$ E), which is located at the mouth of the Air Hitam River to the Tembesi River (Figure 2.1-1). The data for this analysis was provided by the Public Works Agency for Water Resources (Dinas Pekerjaan Umum Bidang Sumberdaya Air) and covers the period 1997-2016. The river catchment area at Pauh hydrological station covers an area of 10,760 $\mathrm{km}^{2}$ ( $84 \%$ of the Tembesi watershed). Water levels were recorded once per day between 8 and $9 \mathrm{am}$, local time, with an automatic water level recorder that uses a floating ball as a mechanical trigger (Roni 2005). River discharge was derived from a site-specific rating curve.

Based on villagers' observations of changing flooding regimes and building on the approach of Wang et al. (2006) and Zhang et al. (2009), we analyzed a potential increase in flood frequency and intensity as well as potential shifts in seasonal patterns of flood events. For this purpose, we investigated (a) the number of days with extreme water levels of the Tembesi River, (b) the average water level rise as well as the frequency and intensity of flash floods, and (c) the average seasonal water level and possible changes. For (a) we defined extreme water levels as water levels when the Tembesi River overflows its natural dams $(11 \mathrm{~m})$. This threshold is based on the reported typical water level of 5-11 m (Anton 2017, Saputra 2017) and double checked with river water level data for days when flood events were reported in the local online newspaper or by the National Board for Disaster Management (BNPB 2019). For (b) we compared the change in water levels between two 
subsequent days over the period 1997-2016 and defined a flash flood as an event with water level rise $>1 \mathrm{~m}$ over two consecutive days. For (c) we calculated the mean water level for each month.

\section{Precipitation}

The only lowland meteorological stations in the vicinity of our study region that offer longterm meteorological measurements are at Jambi Sultan Thaha Airport $\left(01^{\circ} 38^{\prime} 17^{\prime \prime} \mathrm{S}\right.$, $103^{\circ} 38^{\prime} 40^{\prime \prime}$ E, $25 \mathrm{~m}$ a.s.l.), which has been taking measurements since 1978, and in the village Pauh (02 $11^{\prime} 09.6^{\prime \prime} \mathrm{S}, 102^{\circ} 49^{\prime} 01.1^{\prime \prime} \mathrm{E}, 43 \mathrm{~m}$ a.s.l.), where measurements have been available since 2007 (Figure 2.1-1). Both meteorological stations are owned and run by the Indonesian Meteorological Service (BMKG). The areal distance between the two meteorological stations is approximately $110 \mathrm{~km}$ and the areal distance between the Pauh meteorological and hydrological stations is approximately $4 \mathrm{~km}$. Both meteorological stations are located inland, within similar land use structures and relatively flat terrain. Precipitation patterns in the lowlands are mostly dominated by very local and temporary convective rain showers. Precipitation patterns and intensities may thus differ substantially even within small distances. We analyzed monthly accumulated precipitation, precipitation intensity, and seasonal distribution. Precipitation intensity for both meteorological stations was calculated following the SDII climate index (Zhang et al. 2011), where the total sum of precipitation during consecutive wet days (precipitation $>0.1 \mathrm{~mm} \mathrm{~d}-1$ ) is divided by the total number of consecutive wet days.

\section{Land-use change}

Our land-use change analysis builds on a comparison of existing land-use maps for Jambi Province from 1990 and 2013 (Melati 2017). For the purpose of this study, the land-use classes were reclassified to fit our research questions and land-use maps were reanalyzed for the section of the Tembesi watershed.

The maps elaborated by Melati (2017) were based on mixed land use/land cover maps originally developed by the Indonesian Ministry of Environment and Forestry (MoEF; Margono et al. 2016). The classification of these land use/land cover maps was based upon a visual interpretation of $30 \mathrm{~m}$ spatial resolution Landsat imagery with a minimum mapping unit of 6.25 ha. The original 23 classes defined by Margono et al. (2016) were 
enhanced further in a subsequent visual interpretation by Melati (2017) who regrouped some of the former land use/land cover classes to fit land use in Jambi Province. During this enhancement, formerly categorized estate crops were further differentiated into rubber and oil palm land use systems. For this study, we grouped the resulting land use classes by Melati (2017) into the seven most relevant land use classes, namely forest, mixed agriculture, bush/bare land, rubber plantations, oil palm plantations, settlement, and water.

To map wetland areas, we combined available wetland maps for Jambi Province, elaborated by Gumbricht et al. (2017) (https://www2.cifor.org/global-wetlands/), Wahyunto and Subagjo (2003), and Laumonier (1997). An additional land use change analysis was performed on these areas using the land use data provided by Melati (2017).

\section{Soil bulk density and water infiltration capacity}

Published bulk density data $\left(\mathrm{g} \mathrm{cm}^{-3}\right)$ from well-drained sites (Allen et al. 2016) as well as unpublished data from riparian sites were used to evaluate soil compaction after the conversion of forests to monocultures. Bulk density samples were weighed and dried at $105^{\circ} \mathrm{C}$ until constant weight. The data consisted of five replicates per site and soil depth. Sampling depth intervals were 0-10 cm, 10-30 cm, and 30-50 cm soil depth. Sampling sites represented six sites from reference forests, six from rubber, and six from oil palm plantations on well-drained mineral soils as well as four sites of each land use system on riparian soils. Three well-drained mineral soil sampling sites were located within the Tembesi watershed whereas three well-drained mineral sampling sites, as well as the riparian soil sampling sites, were located just outside the watershed, but within the same lowland of Jambi province (Figure 2.1-1). Acrisols with a clayish to sandy loam texture were the dominant soil type in well-drained mineral soils (Guillaume et al. 2015), whereas riparian soils were classified as stagnic Acrisol and Stagnosols with a loamy texture (Waite et al. 2019).

To assess the water infiltration capacity of soils, we measured saturated soil hydraulic conductivity $\left(\mathrm{K}_{\mathrm{fs}}, \mathrm{cm} \mathrm{h}^{-1}\right)$, which describes the movement of water through soil under watersaturated conditions. The main measurements were performed with a dual-head infiltrometer (Saturo, Meter, USA) in a commercial oil palm plantation where a biodiversity enrichment experiment was established in 2013 (EFForTS-BEE; Teuscher et al. 2016). In this 
experiment, multiple native tree species were planted and natural regeneration of the vegetation was allowed. The experimental plots have varying tree diversity levels (from 0 to 6 native tree species) and plot sizes (from $25 \mathrm{~m}^{2}$ to $1600 \mathrm{~m}^{2}$ ) following a random partition design (Teuscher et al. 2016). We carried out one measurement per plot in March 2018 in the subplot in four control plots (management-as-usual oil palm monoculture plantation) and 33 experimental plots where different tree species have been planted and vegetation regenerates naturally (Appendix A 2.1-1). We carried out additional, confirmatory measurements of $\mathrm{K}_{\mathrm{fs}}$ with a conventional manual double-ring infiltrometer in a commercial, intensively managed monoculture oil palm plantation in the same region (PTPN VI, at approx. $40 \mathrm{~km}$ distance from the biodiversity enrichment experiment). Six study plots were measured between June and September 2018.

\section{Groundwater level}

To investigate the effect of the land use system on groundwater level, we measured groundwater levels in oil palm and rubber riparian monocultures as well as in forest riparian locations with an OTT Orpheus Mini water level logger (OTT HydroMet GmbH, Kempten, Germany). Measurements were conducted at the same 12 riparian locations that were also sampled for soil bulk density. The logger was installed at a depth of between 2.5 and $4.5 \mathrm{~m}$ in a metal borehole equipped with a fine sieve on its lower end. Data was available from July 2017 to March 2019 at four different locations for each of the three land use systems (forest, rubber plantation, oil palm plantation).

\section{Statistics and data analyses}

We applied the Mann Kendall Trend Test (M-K test; Gilbert 1987) to investigate possible changes in the seasonal and monthly pattern of river water level and accumulated precipitation. The M-K test $\tau$ ranges from -1 to 1 where values above 0 indicate a positive trend whereas values below 0 indicate a negative trend and trends are significant for $\mathrm{p}<$ 0.05. To test for statistical differences in soil bulk density and $\mathrm{K}_{\mathrm{fs}}$ between different land use systems, we performed a nonparametric Kruskal-Wallis Test (differences are significant for $\mathrm{p}<0.05$; Townend 2004). All statistical analyses and graphing were performed using Rstudio (version 1.1.463), except for the land use change analyses, which were performed in 
ArcMap (version 10.6.1) and Excel and visualized with the help of the online tool sankeyMATIC (http://sankeymatic.com/).

\subsubsection{RESULTS}

\subsubsection{Qualitative interview data}

\section{Local ecological knowledge on changing flooding regimes}

Of 33 interview partners in the Air Hitam subdistrict, 29 mentioned having perceived changes in the intensity, frequency, or predictability of flooding over the last 10-15 years. A common observation among villagers was that flooding nowadays would occur faster, and even after short rainfall events. In their memory, flooding in the past had only occurred after prolonged rainfall (Table 2.1-1: Q1). Heavy flood events, in the past common at a return period of about five years, nowadays were said to occur almost every year (Table 2.1-1: Q2). Moreover, villagers complained that contrary to former seasonal patterns of flooding, today, the timing of flood events was no longer predictable (Table 2.1-1: Q3). Only five farmers residing in wetland areas had noticed decreases in flood height and length, which in most cases can be explained by drainage activities on these lands.

Table 2.1-1: Quotes illustrating villagers' perceptions of changing flooding regimes. (Translations by J. Merten)

\section{Perceptions of changing flooding regimes}

Q1: "[The flooding in the past] was different, very different. In the past when rubber farmer it only rained for one day, the river did not directly overflow. But now, after (riparian one hour of heavy rain, it already overflows. [...] It started to be like that ever plantation, 14 since many people opened the land for oil palm. [...] Now, there is constant

Nov. 2017) flooding."

Q2: "Flooding happened since the past. But as far as I remember, in the past village gov. flooding occurred rarely, and it was rarely very high. Sometimes, once in five years there was a big flooding, but now it happens almost every year."

representative (Air Hitam, 13 July 2016)

Q3: “Now it is difficult to predict [the flooding]. Normally, [...] starting from October, November, December, there would be flooding. But last year, in village gov. representative May, and in April, there was flooding as well. We cannot predict it anymore. In the past, when the forest was still wide, we could still predict the (Air Hitam, 7 June 2016) flooding."

Explanations given for these observed changes in flooding regimes were multiple. In total, 25 of the interview partners associated changes in intensity and frequency of flood events 
directly with land use change and plantation management. They agreed that flooding regimes started to change after vast forest areas had been converted to rubber and oil palm plantations. Because of this conversion, according to them, the capacity of the landscape to "retain" or "save" water had decreased. Among the villagers, forests were known to "hold back" rainwater and release it only slowly to the rivers (Table 2.1-2: Q4). Individual interview partners referred to forests as acting as a "protective shield" that would prevent the occurrence of natural disasters (Table 2.1-2: Q5).

The capacity to store water in the landscape was attributed to forest areas, but not to plantations. Some farmers had observed that rainfall in their plantations could not be absorbed and retained by the soil (Table 2.1-2: Q6). Others further observed that rainfall in their plantations had flushed away large quantities of soil. This soil was then observed to flow into the rivers where it would result in shallower riverbeds (Table 2.1-2: Q7). In addition to the protective function of upstream forest areas against flood occurrence, individual interview partners also highlighted this function in regard to swamp and peat areas. As a village head recounted, before these peatlands were converted to oil palm plantations, they had absorbed and stored large amounts of water (Table 2.1-2: Q8).

Perceived causes for changes in the temporal predictability of flood events were not as consistent as for changes in flood frequency and intensity. Some interview partners associated seasonal changes in flood events with land use change (Table 2.1-1: Q3, Table 2.1-2: Q8). Others, however, also perceived that rainfall would no longer follow seasonal patterns and had become difficult to predict (Table 2.1-2 Q10).

Villagers owning land close to rivers had further noted a very recent ( $3-5$ years) change in flooding regimes. This change was attributed to the construction of flood control infrastructure by oil palm companies managing wetland areas. Newly constructed dams and drainage gates were reported to lead to a redistribution of floodwaters. These were blamed for increasing the length and depth of flood events on smallholder farmers' plantations located adjacent to or downstream of such infrastructure and further complicating villager's prediction of flood events (Table 2.1-2: Q9 and Q10).

The reported increases in flood frequency and intensity have significant socioeconomic impacts for villagers in our case study villages. Increases in flood frequency, as well as 
difficulties in predicting seasonal flood events, are of particular importance to food crop farmers, who often cultivate riparian floodplains (see introductory quote of this article). For such crops, unexpected flood events, according to our interview partners, often imply complete harvest failures. According to interview partners, but also documented in government reports and local media, such harvest failures caused by flooding constitute a major reason for food crop farmers to convert their fields into oil palm plantations (Bakhori 2010, The Jakarta Post 2014, Jambi Provincial Government 2016). For the interviewed rubber and oil palm farmers, increases in flood frequency and intensity often imply a reduction of tree and palm productivity as well as an impairment of harvesting activities, fertilization, and the transport of plantation produce. Moreover, villagers residing in settlements adjacent to rivers reported being evacuated from their houses several times during the past years.

Table 2.1-2: Quotes illustrating villagers' evaluations of possible causes of changing flooding regimes. (Translations by J. Merten)

\section{Possible causes of changing flooding regimes}

Deforestation

Q4: "In the past the water did not flow down that strong, because it was held back by the trees. But now, as soon as it rains there will be flooding. All the water accumulates in the branches of the river."

Q5: "[The trees] hold back the rain, so that not all the rain falls down. Then we have less flooding. But if all the rain falls down, on the earth, the flooding will be higher. [...] Because the forest has already been cut, that's why. The forest can absorb all the disasters."

elderly villager (Air Hitam, 1 Nov. 2017)

elderly indigenous man (Air Hitam, 16 June 2016)

rubber farmer (riparian plantation, 14

Nov. 2017) quickly absorbed by the earth, by the soil. But now [...] as soon as it rains maybe the water does not enter the earth anymore, it directly flows to the river."

Q7: "The difference is that in the past there was rarely flooding. Because there was no erosion, there were still main other trees. The river was still deep, but now the river is shallow [...] because the soil slides off into the river, that's why it is shallow, that is why floods today happen easily."

Ecological function of wetlands

Q8: "Nowadays, we cannot predict the seasons anymore. [...] Each time it rains, there is flooding. [...] In the past the forest was wide, but now it is all oil palm, that's why the water is absorbed slowly. And also all the peatlands have been destroyed. In the past, when there was still peat, all the water was absorbed by the peat." (riparian plantation, 15. Nov. 2017)

village gov. representative (Air Hitam, 15 Aug. 2016) rubber farmer 
Water infrastructure

Q9: “My oil palm in the past never got flooded, but now the water is deep and the oil palms cannot be harvested. Because the water cannot spread anymore. In the past it could flow over there [direction of peatlands], but now

oil palm farmer (Air Hitam, 21

July 2016) it is blocked by the company's dam, and then the water flows over here. In the past the water flowed to [village name]. The water split [into several arms], but now, because there is the dam, the water flows to the village." Q10: "In the past, before there was a dam built around inti [the company's plantation], the flooding would drop fast. Now because of the dam, it takes longer for the water level to drop. The water comes fast, but drops slowly. [...] [Before the dam was built] the flooding lasted two days, and then it would drop for two days. After five days the water was already gone. [...] But now, it lasts at least half a month, if it is a big flooding."

Climate change

Q10: "The seasons are not certain anymore today [...] Normally, the flooding seasons starts in November, [...] [It] lasts 4 months. But because there is a

rubber farmer (riparian change in the weather, we cannot predict it anymore. [...] The amount of rain nowadays is not certain anymore. [...] In the past it was comfortable. [...] Our plantation, 14 ancestors, when they wanted to plant rice, they would count the day, would

Nov. 2017) count the month. [...] But now it is difficult because of the change, the change in the weather."

\section{Land use history and management in wetland areas}

To analyze land use history and management in wetlands areas in the Tembesi watershed we compared interview data across six case study villages with vast wetland areas. Interviews revealed that wetland areas in our case study villages were only extensively used before the mid-1980s. In autochthonous villages, riparian floodplains were traditionally cultivated only during the dry season and mainly planted with staple crops such as dry rice, corn, or soybean. Shallow swamp areas were partly used for wet-rice cultivation. Deeper swamp and peatland areas, on the contrary, mainly remained forested.

Starting in the mid-1980s, forested wetlands in our case study villages were progressively converted into plantation systems. At that time a national resettlement program (transmigrasi) aimed, inter alia, at the economic development of supposedly undeveloped areas across Jambi Province, including expansive peatland areas (for more details see Fearnside 1997). Three of our case study villages were established under this program. Following the establishment of these villages, peat swamp forests adjacent to them were converted into industrial oil palm and rubber plantations. These plantations were jointly managed by settlers and industrial companies. In the other three autochthonous villages, 
plantations expanded into wetland areas more recently, starting around the early 2000s. A profitable plantation development on these soils requires substantial financial and technical capital for water management. Therefore, villagers interviewed argued that the conversion of wetland forests was mainly initiated by independent private and commercial investments that progressively expanded into areas that were formerly considered marginal. Smallholder farmers who independently tried to develop these areas often sold their land or left it only sporadically managed.

Nowadays, wetland areas in all studied villages are almost exclusively planted with monoculture oil palm plantations. According to the interview partners, the oil palm is the only crop known that can be profitably managed in inland wetlands. A rubber plantation developed on peat soils in one of the transmigration villages had been abandoned after a few years because of extremely low productivity. Annual crops planted in wetland areas have decreased in extent over the past decades because of economic disincentives as well as the above-mentioned challenges associated with changing flooding regimes.

Changes in local flooding regimes appear to also concern companies and private investors who own oil palm plantations in the wetlands of our case study villages. Prior to plantation development, these had typically established large-scale drainage systems on their lands. In several cases, however, these drainage systems have recently been complemented with flood protection infrastructure such as flood control dams. Along the Air Hitam River, at least three larger oil palm companies have built new flood control dams during or shortly before our field visits (2012-2017; Figure 2.1-2). According to a representative of one of these companies, the need for additional water infrastructure arose because of an observed increase in flood frequency. In accordance with the villagers' observations, he associated this increase with upstream deforestation activities. Consequently, the company constructed additional drainage channels and flood control dams, and made use of water pumps to mitigate flood impacts on their plantations. According to the villagers, such infrastructure redistributes floodwaters locally, increasing the frequency and intensity of flood events on their own plantations (see Table 2.1-2: Q9 and Q10). In two villages, village authorities complained that they had not been informed about nor involved in the planning of the flood control dams. In consequence, villagers tried to protest against the building of 
such dams by writing letters to local authorities or organizing roadblocks. Yet, they were not successful in stopping such constructions at the time of research.

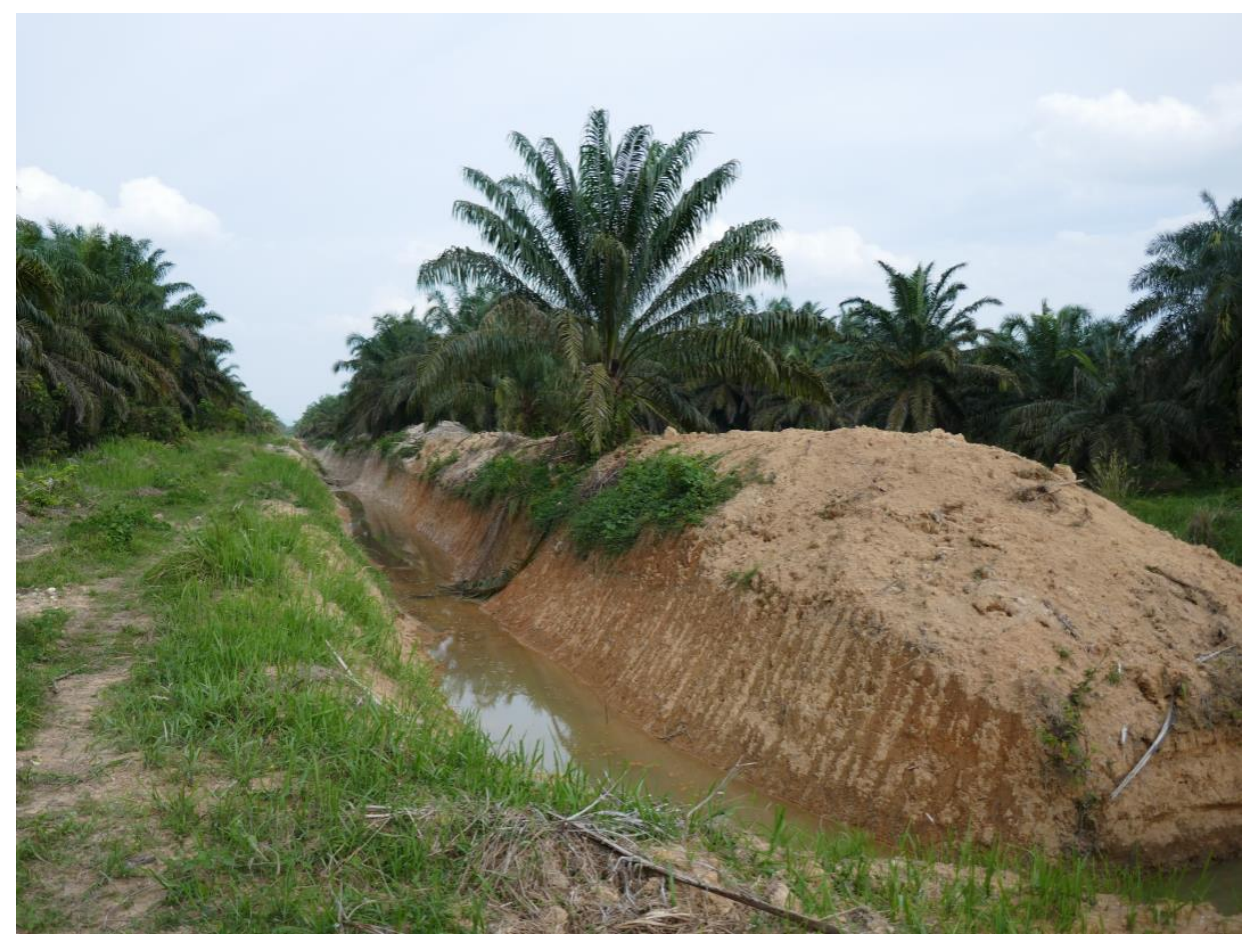

Figure 2.1-2: Recently built flood control dam on an agro-industrial oil palm plantation.

\subsubsection{Quantitative environmental measurements}

\section{River water level}

To interrogate water level data for the observed changes in the frequency and intensity of flood events we used the nonparametric Mann-Kendall trend analysis and linear regression. On a monthly basis, the Tembesi River at Pauh hydrological station had a mean water level of $6.07 \mathrm{~m}$ ( $\pm 1.29 \mathrm{~m}$ standard deviation) over the period 1997-2016 (A 2.1-2). On average, mean water levels are $6.88( \pm 1.42 \mathrm{~m})$ in the wet season (October-May), which is $1.9 \mathrm{~m}( \pm 1.35 \mathrm{~m})$ higher compared to the dry season (June-September; Appendix A 2.1-2). Our trend analysis showed a small but significant increase of annual mean river water levels by $0.10 \mathrm{~m}$ yr- 1 over the 20 -year study period (Mann-Kendall $\tau=0.18, \mathrm{p}<0.001$ ). This observed increase in mean river water levels was more pronounced in the wet season, with $0.12 \mathrm{~m}$ yr-1 (Mann-Kendall $\tau=0.29, \mathrm{p}<0.001$ ) compared to the dry season, with a respective increase of $0.06 \mathrm{~m}$ yr-1 (Mann-Kendall $\tau=0.14, \mathrm{p}<0.05$; Appendix A 2.1-2). Extreme water levels of $>11 \mathrm{~m}$, as an indicator for flood events, occur almost exclusively during the wet season $(92 \%)$ in coherence with intense precipitation $\left(R^{2}=0.99\right.$; Figure 2.1-3, Appendix A 
2.1-3). According to the Mann-Kendall test, the frequency and duration of such extreme river water levels has increased significantly over the study period (Mann-Kendall $\tau=0.45$, $\mathrm{p}<0.01 ;$ Appendix A 2.1-3).

Because villagers reported that flood events today would occur even after only short rainfall events, we investigated changes in the frequency and intensity of flash floods as well as in the average water level rise. Water levels during a flash flood event (a rapid increase in river water level $>1 \mathrm{~m}$ between two consecutive days) increase on average by $1.59 \mathrm{~m}( \pm 0.67 \mathrm{~m})$ during such events. The frequency and intensity of such flash flood events remained relatively constant over the study period (Mann-Kendall $\tau=0.04, p=0.36$ ). However, our analysis of the average water level rise of the Tembesi between two consecutive days (Appendix A 2.1-3) indicates weak evidence for an increase in the fluctuation of river water levels (Mann-Kendall $\tau=0.16, p<0.01$ ).

To interrogate a changing predictability of flood events we analyzed seasonal patterns of extreme water levels, mean river water levels and flash flood events. However, we did not find any significant shift in the seasonal patterns of mean river water levels (Table A2.1) or flash floods and the increase of extreme water levels was only significant $(p<0.05)$ in the wet season, i.e., in January and November (Figure 2.1-3d, Appendix A 2.1-3).

The analyses of river water levels show that flooding is an important component of the Tembesi River hydrology. Therefore, we used a digital elevation model and the river network to generate a flood risk map (see Appendix: Determination of flood-risk areas). We found that in the case of a 100-year flood event, about $408 \mathrm{~km}^{2}$ of land adjacent to local rivers would be flooded, with strong negative impacts on local infrastructure, agriculture and villages. 


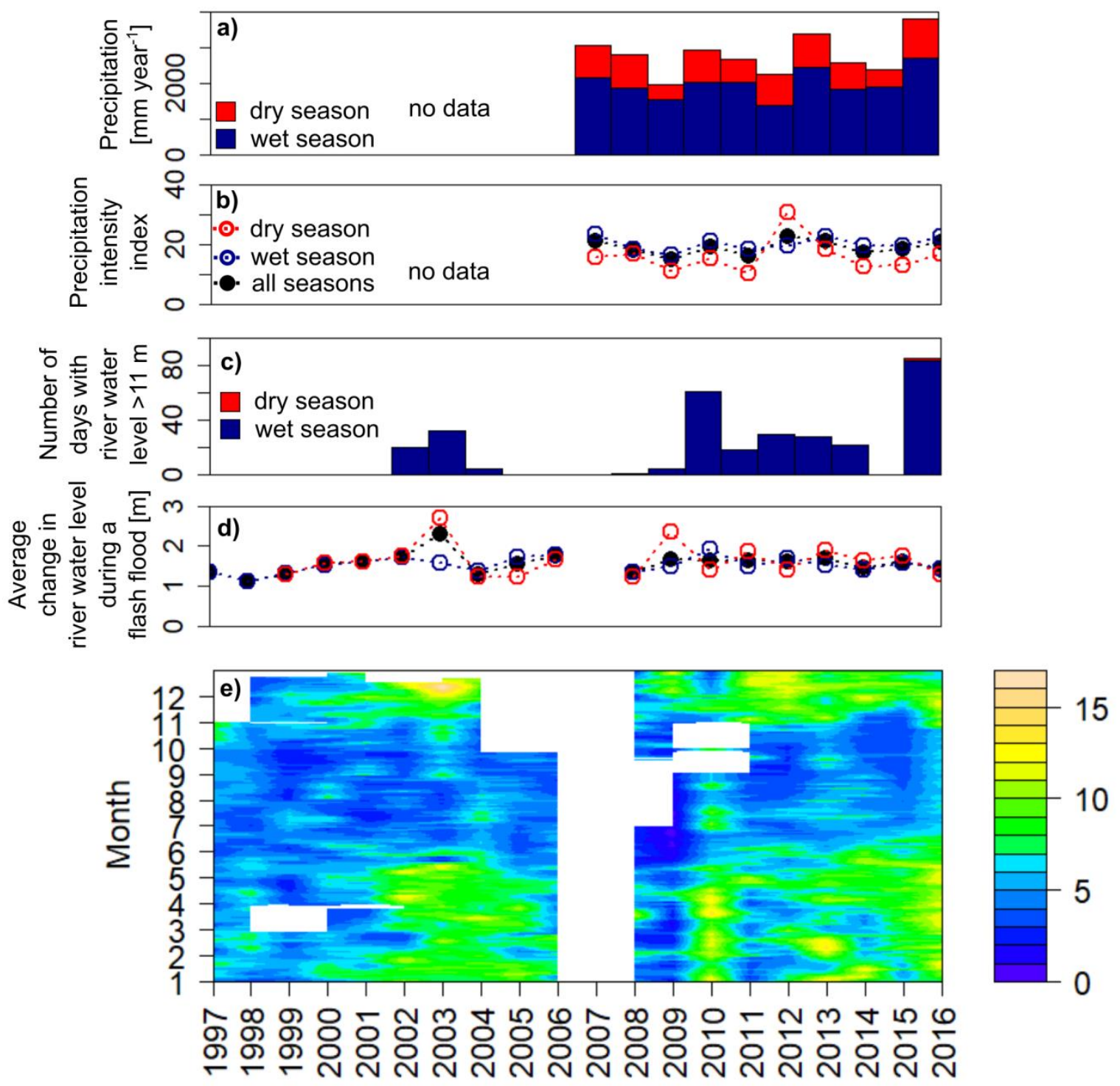

Year

Figure 2.1-3: Accumulated precipitation (a) and mean precipitation intensity index (b) at Pauh meteorological station during the period 2007 to 2016. Days within one year with water level of Tembesi River above $11 \mathrm{~m}$ (c), average change in river water level of the Tembesi River during a flash flood event (d), and fingerprint map of Tembesi River water level at Pauh hydrological station (e) during the period 1997 to 2016 (no data for 2007).

\section{Precipitation}

Precipitation patterns at Pauh meteorological station are well reflected in the behavior of the Tembesi River water levels recorded at Pauh hydrological station. However, precipitation patterns from Jambi airport do not generally explain the water level characteristics at Pauh hydrological station, probably because of the station being located outside of the Tembesi watershed. At both meteorological stations, monthly accumulated precipitation displays large seasonal and annual fluctuations (Figure 2.1-3a, Appendix A 2.1-4 and A 2.1-6). At Pauh, November and December show the highest rates of 
precipitation and the strongest precipitation intensity (Appendix A 2.1-4 and A 2.1-5), which is also reflected in the annual peak of river water levels during those two months (Figure 2.1-3e). At Jambi, where we have a longer record of precipitation measurements, April shows the highest accumulated precipitation and precipitation intensity is strongest in March (Appendix A 2.1-6 and A 2.1-7).

At both meteorological stations, we found no clear trend in total accumulated precipitation and no shift in the distribution of precipitation between the wet and the dry season (Appendix A 2.1-4 - A 2.1-7). At Pauh however, we found a clear trend toward higher precipitation at the end of the wet season in May (Mann-Kendall $\tau=0.60, p<0.05$ ) and at the beginning of the wet season in November (Mann-Kendall $\tau=0.56, p<0.05$; Appendix A 2.1-4), which, for the latter, is in agreement with our findings of increased river water levels at the beginning of the wet season (Appendix A 2.1-5).

\section{Land-use change}

In 1990, about half of the Tembesi watershed was covered with forest areas. Between 1990 and 2013, this forest area decreased by $25 \%$, from $6835 \mathrm{~km}^{2}$ to $5108 \mathrm{~km}^{2}$. Today, most of the remaining forest area is located in the upstream, mountainous area of the watershed (Fig. 1; for an accuracy assessment of the land use classes see Appendix A 2.1-8). The forest loss in the watershed can mainly be explained by an increase in plantation area as well as in bush/bare land (Figure 2.1-4). From 1990 to 2013 the area cultivated with oil palm plantations expanded by $54 \%$, from $939 \mathrm{~km}^{2}$ to $1451 \mathrm{~km}^{2}$. Rubber plantations increased by $25 \%$, from $2714 \mathrm{~km}^{2}$ to $3404 \mathrm{~km}^{2}$. The area of bush or bare land increased by $59 \%$, from 597 $\mathrm{km}^{2}$ to $947 \mathrm{~km}^{2}$. In consequence, in 2013, oil palm plantations covered $11 \%$, and rubber plantations $25 \%$ of the Tembesi watershed. The area of mixed agricultural land has remained almost the same over the same period, covering $15 \%$ of the watershed's area in 1990 and $16 \%$ in 2013.

According to the wetland map we created; wetland areas constitute $8.35 \%$ of the Tembesi watershed $\left(1116 \mathrm{~km}^{2}\right)$. In 1990, about one-third of these wetlands were covered with forests, while $54 \%$ of the wetlands were used for different types of agriculture (Figure 2.1-4). The proportionate loss of forest cover in wetlands was even greater than in the whole watershed. From 1990 to 2013, forest areas in the watershed's wetlands decreased by 73\%, 
from $347 \mathrm{~km}^{2}$ to $93 \mathrm{~km}^{2}$. This implies that $15 \%$ of the total forest loss between 1990 and 2013 in the Tembesi watershed occurred in wetland areas although these comprise only $8.35 \%$ of the whole watershed. The converted forest area was almost exclusively planted with oil palm plantations, which almost doubled in area from 1990 to 2013, from $244 \mathrm{~km}^{2}$ to $479 \mathrm{~km}^{2}$, respectively. In fact, 33\% of all newly developed oil palm plantations in the Tembesi watershed have been established in wetland areas.

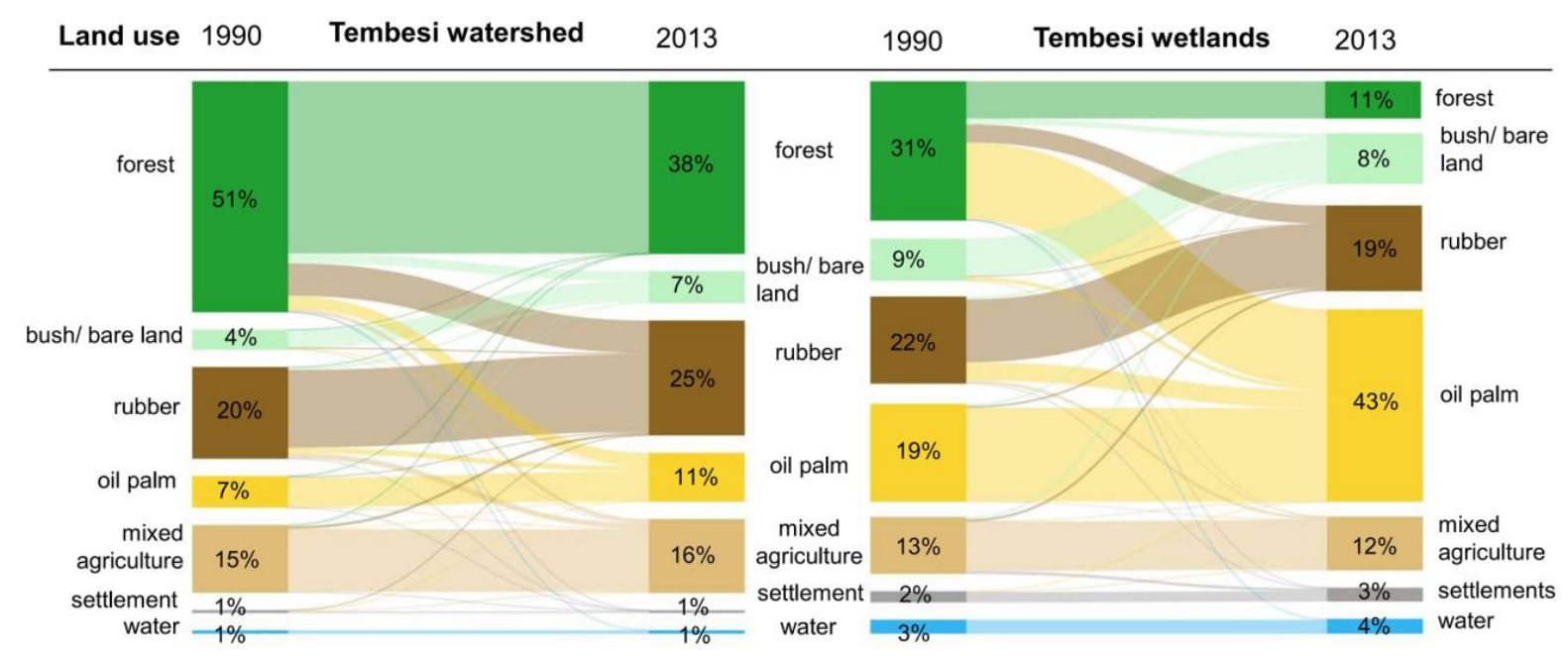

Figure 2.1-4: Land use change in the Tembesi watershed and its wetland areas between 1990 and 2013 (based on land use data by Melati 2017). Total area: Tembesi watershed 13,370 km², wetlands $1167 \mathrm{~km}^{2}$.

\section{Soil bulk density and water infiltration capacity}

Bulk densities of rubber and oil palm plantations in the topsoil $(0-10 \mathrm{~cm})$ were $1.3-\mathrm{fold}$ higher $\left(1.14 \pm 0.05\right.$ and $1.13 \pm 0.05 \mathrm{~g} \mathrm{~cm}^{-3}$, mean \pm standard error $)$ than at the reference rainforest sites (Figure 2.1-5). In contrast to the topsoil, bulk densities in deeper soil layers $(30-50 \mathrm{~cm})$ showed similar values across all land use systems $\left(1.37 \pm 0.03 \mathrm{~g} \mathrm{~cm}^{-3}\right)$.

Saturated soil hydraulic conductivity $\left(\mathrm{K}_{\mathrm{fs}}\right)$ in an oil palm monoculture plantation $(6.5 \pm 1.7$ $\left.\mathrm{cm} \mathrm{h}^{-1}, \mathrm{n}=4\right)$ was three times lower than in the oil palm biodiversity experiment $(22.6 \pm 2.6$ $\mathrm{cm} \mathrm{h}^{-1}, \mathrm{n}=33$; Figure 2.1-5), suggesting higher surface runoff in the former. Additional measurements with a conventional double-ring infiltrometer in another oil palm plantation gave lower $\mathrm{K}_{\mathrm{fs}}\left(0.7 \pm 0.2 \mathrm{~cm} \mathrm{~h}^{-1}, \mathrm{n}=6\right)$. 

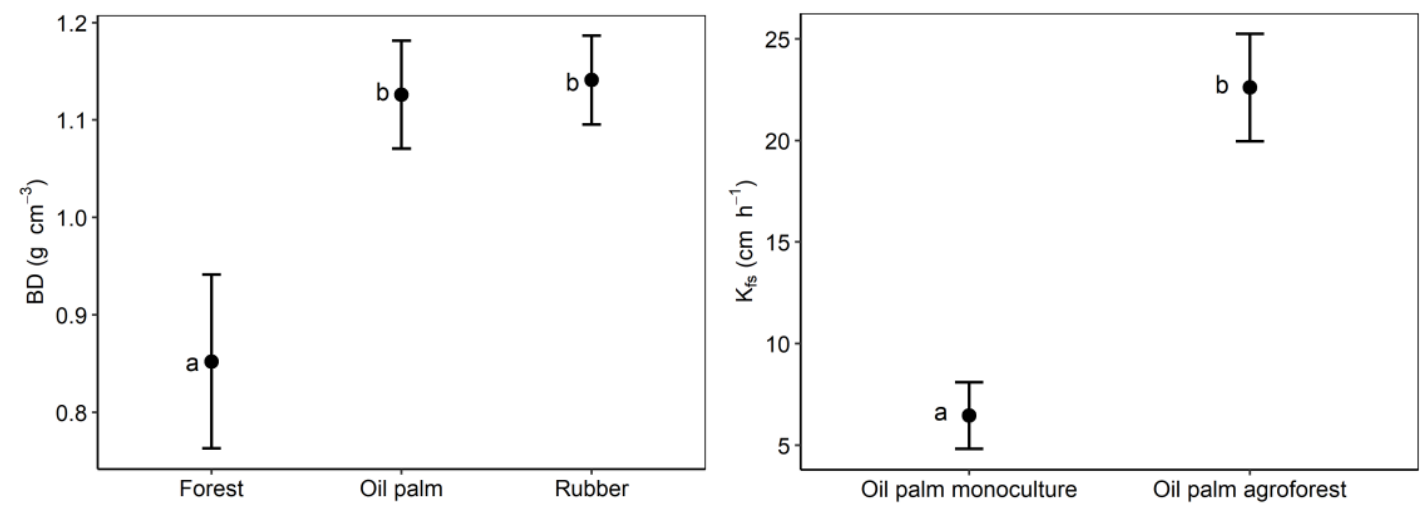

Figure 2.1-5: Topsoil (0-10 $\mathrm{cm})$ bulk densities $\left(B D, \mathrm{~g} \mathrm{~cm}^{-3}\right)$ at 10 sites each in forest, rubber, and oil palm plantations (sites described in Drescher et al. 2016). The dots represent means and the error bars the according standard errors. Different letters represent significant differences among groups (Kruskal-Wallis test, $p<0.05$ ) (left). Saturated soil hydraulic conductivity $\left(K_{f s}, \mathrm{~cm} \mathrm{~h} \mathrm{~h}^{-1}\right)$ in oil palm monoculture control plots $(n=4)$ and in plots within the oil palm biodiversity experiment ( $n=33$; sites described in Teuscher et al. 2016). The dots represent means and the error bars the according standard errors. Different letters represent significant differences among groups (Kruskal-Wallis test, $p<0.05$ ) (right).

\section{Groundwater levels}

Groundwater table (GWT) measurements in riparian areas showed that the mean GWT in the rubber and oil palm plantations is lower than in the forest reference sites ( Figure 2.1-6). On average, the GWT during the period July 2017 to April 2019 was $0.55 \mathrm{~m}( \pm 0.27 \mathrm{~m})$ below the soil surface in the forests, and $1.03 \mathrm{~m}( \pm 0.39 \mathrm{~m})$ and $1.24 \mathrm{~m}( \pm 0.50 \mathrm{~m})$ below the soil surface in the rubber and oil palm plantations, respectively. In addition, GWTs in the plantations (rubber and oil palm) showed higher amplitudes compared to the GWT in the forests (Figure 2.1-6b). After a rainfall event, the GWT in the plantations can increase up to $1.5 \mathrm{~m}$ within a few hours while in the forests, the increase in the GWT after a rainfall event is less pronounced, with a maximum of $\sim 0.5 \mathrm{~m}$ (Figure 2.1-6). Although the mean GWT in the plantations is lower than in the forests, GWTs in the plantations regularly exceed the respective GWT of the forests. This indicates that after a rainfall event, the rubber and oil palm plantations are more prone to flooding than the forests. 


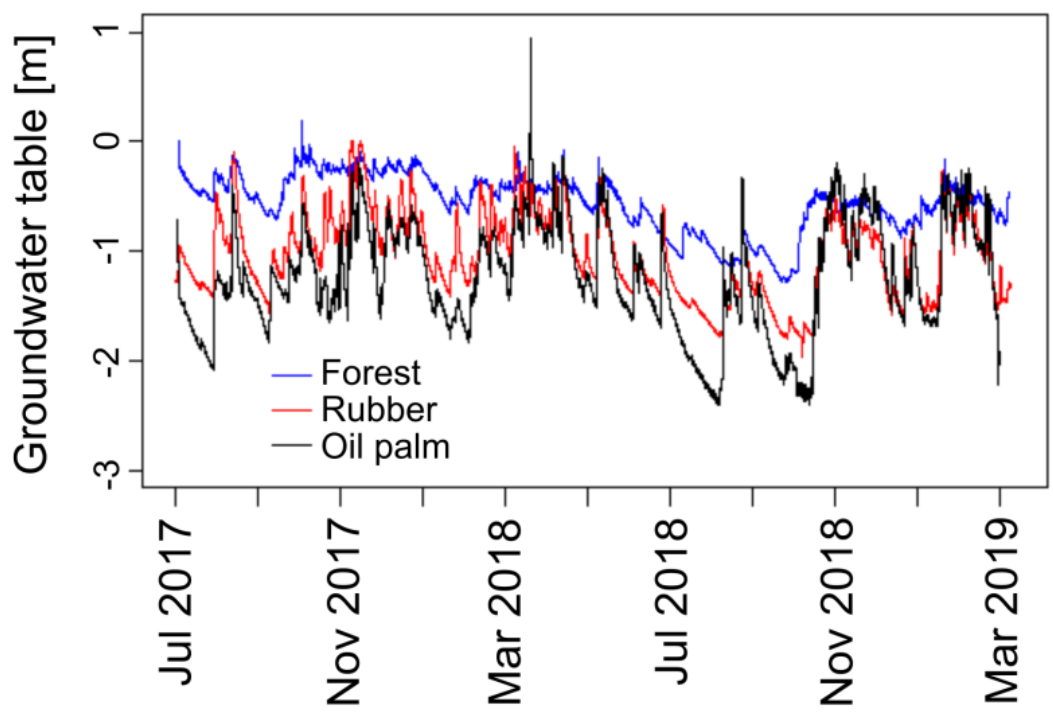

Figure 2.1-6: Development of average groundwater table at forest $(0.55 \pm 0.27 m, n=4)$, rubber $(1.03 \pm 0.39$ $m, n=4)$, and oil palm $(1.24 \pm 0.50 m, n=4)$ riparian locations during the period July 2017 to April 2019.

\subsubsection{DISCUSSION: INTEGRATING INSIGHTS FROM LOCAL ECOLOGICAL} KNOWLEDGE AND SCIENTIFIC MEASUREMENTS

\subsubsection{Comparing villagers' observation of changing flooding regimes with stream flow data}

Villagers interviewed for this study reported an increase in flood frequency and intensity following extensive land use change toward rubber and oil palm monoculture plantations during the past two decades. These findings are in line with the observed increase in frequency and duration of extreme river water levels $(>11 \mathrm{~m} ; \tau=0.45)$. Government reports from Jambi Province provide some additional support to these measurements as they discuss flooding as an increasing environmental problem across Jambi Province and beyond the Tembesi watershed (Minister of Public Works 2012, Batanghari Watershed Office 2016, Jambi Provincial Government 2016). They are also in line with other studies across Indonesia, where local people associated increases in flood frequency and intensity with land use change from forests to oil palm plantations and other types of land use (Obidzinski et al. 2012, Larsen et al. 2014, Wells et al. 2016, Kelley and Prabowo 2019). Our findings further correspond with studies showing increases in streamflow (Adnan and Atkinson 2011) and in the number of days flooded (Tan-Soo et al. 2016), which is associated with land use conversion to rubber and oil palm plantations. 
The interviewed villagers further reported that following land use conversion, flood events have become difficult to predict because water levels today rise faster after rainfall events and the occurrence of flooding has partly shifted in seasonality. A decreasing predictability of flood events following land conversion has also been a common observation by villagers in different areas across Indonesia (Leimona et al. 2015, Kelley and Prabowo 2019). Our water level data, however, showed no substantial evidence supporting these observations by local villagers. Flash flood events of the Tembesi River have not changed in frequency, intensity, or seasonality over time and significant increases in extreme water levels were only found during the wet season. Only the slight increase in average water level rise $(\tau=$ 0.16) provides a small indication supporting villagers' observation of larger fluctuations in water levels. Because discharge data is only available from one hydrological station in the Tembesi watershed, our data, therefore, provide very selective insights into hydrological processes at the watershed scale. As the catchment area upstream of our hydrological station covers over $10,000 \mathrm{~km}^{2}$, flash flood events in smaller subcatchments may not result in significantly higher water levels of the Tembesi River. In general, it has been found that the impacts of land use change on river water levels may be larger in smaller watersheds (Bruijnzeel 1990, van Dijk et al. 2009). Farmers who own plantations adjacent to smaller streams, e.g., the Air Hitam River, may thus observe larger changes in water levels than are reflected in the water levels of the Tembesi River. Indications supporting this hypothesis can be found in our measurements of groundwater tables, which show rapidly increasing water levels in rubber and oil palm plantations after rainfall events.

\subsubsection{Potential contributions of local climate change to changing flooding regimes}

Several interview partners reported seasonal shifts in local rainfall patterns, which could thus potentially provide an explanation for the villagers' reports that flood events have become difficult to predict. Our analysis of precipitation data may partly explain the villagers' complaints as it indicates a clear shift in the seasonal distribution of precipitation toward higher precipitation rates at the end of the wet season in May. Similar accounts about increasingly unpredictable rainfall patterns were reported from farmers across different regions in Jambi Province (Merten et al. 2016, Martens 2017, Rödel 2018). Considering this widespread observation, the measured changes in the seasonal 
distribution of precipitation appear relatively small. Further data from different meteorological stations across Jambi Province would thus be needed to discuss the villagers' observation of changing seasonal rainfall patterns in more detail.

Changes in rainfall patterns could further provide an explanation for the measured increase in the average water levels of the Tembesi River. However, our analysis of precipitation data at Pauh and Jambi airport meteorological station showed that the total amount of precipitation as well as the overall precipitation intensity has remained relatively constant over the past decades. Our precipitation data available for the Tembesi watershed, however, only covers the lowland areas. Hence, we cannot rule out changes in precipitation patterns in the highland regions of the Tembesi River watershed, which may have contributed to the observed increase in water levels.

Deforestation can modify rainfall patterns because of vegetation-atmosphere interactions at various spatial scales (Lawrence and Vandecar 2015, Spracklen et al. 2018). Large-scale forest conversion, as in the Tembesi watershed, typically leads to a reduction of rainfall and therefore river discharge (Lawrence and Vandecar 2015). However, this might be different in the case of forest conversion to oil palm plantations in which evapotranspiration remains relatively high (Röll et al. 2019). On the other hand, deforestation in heterogeneous landscapes such as the Tembesi watershed may increase rainfall over deforested areas and thereby increase both river discharge and river water levels (Lawrence and Vandecar 2015). Moreover, global climate change is expected to increase both total annual precipitation and extreme precipitation in Southeast Asia (Ge et al. 2019). Although such trends are not yet identifiable in our precipitation data, such developments could further increase both river discharge and river water levels in the future. Long-term climate records and a dense network of meteorological stations are therefore indispensable for studying the current and future linkages between precipitation and river discharge.

\subsubsection{Potential contributions of land use change to changing flooding regimes}

\section{Evidence for altered hydraulic soil properties after forest conversion}

The villagers interviewed in this study reported that flooding regimes started to change after vast forest areas had been converted to rubber and oil palm plantations. Our land use 
change analysis, together with our measurements of soil properties and groundwater levels in different land use systems, provide indications that the large-scale land use change might have contributed to changes in the ecohydrological functioning of the Tembesi watershed. High soil compaction in monoculture rubber and oil palm land use systems is in line with results of other studies in the tropics, showing that forest conversion and associated soil compaction leads to 1.2- to 1.3-fold increases in topsoil bulk density (Don et al. 2011, Li et al. 2012). Higher bulk densities in monoculture plantations than in forests are likely the result of severe soil erosion and changes in soil properties (Guillaume et al. 2015, 2016), e.g., compaction caused by heavy machinery during deforestation or subsequent harvesting operations. Such increases in soil compaction may go along with significantly lower saturated hydraulic conductivities (Kfs; Pachepsky and Park 2015). Our measurements indicate that subsoil bulk densities $(30-50 \mathrm{~cm})$ remain unchanged across the different land use systems, which corresponds with a previous study from the region (de Blécourt et al. 2013). However, it has been suggested that increases in topsoil bulk density alone are sufficient to strongly reduce $\mathrm{K}_{\mathrm{fs}}$ in soils of the humid tropics (Hassler et al., 2011). In a metaanalysis, Pachepsky and Park (2015) suggested that topsoil bulk densities of around $1.36 \mathrm{~g}$ $\mathrm{cm}^{-3}$ form a critical threshold, beyond which they have altered hydraulic properties such as hydraulic conductivity, permeability, and porosity due to soil compaction. In our study, more than $30 \%$ of the assessed oil palm and rubber plantations cross this threshold. Such changes in hydraulic soil properties are further supported by our measurements of saturated hydraulic conductivity $\left(\mathrm{K}_{\mathrm{fs}}\right)$. Our very low $\mathrm{K}_{\mathrm{fs}}$ values coincide with a previous study in the region, where soil water infiltration in oil palm monocultures $\left(3 \mathrm{~cm} \mathrm{~h}^{-1}\right)$ was reported to be $60 \%$ lower than in rubber plantations $\left(7.8 \mathrm{~cm} \mathrm{~h}^{-1}\right)$ and more than 15 -times lower than in reference rainforests $\left(47 \mathrm{~cm} \mathrm{~h}^{-1}\right.$; Tarigan et al. 2018). These results, as well as ours, thus point to very low $\mathrm{K}_{\mathrm{fs}}$ in conventionally managed oil palm monocultures, which is most likely related to the described soil compaction. These observations are in agreement with the villager's observation that soils in plantations do not effectively absorb or retain rainwater.

The type of vegetation in riparian areas is critical for infiltration capacity, overland flow, and groundwater recharge (Alvarenga et al. 2017). Our groundwater table (GWT) analysis in riparian areas showed that rubber and oil palm plantations have lower GWTs compared to forests. This might be related to the relatively high soil compaction and the low water 
infiltration capacities in monoculture plantations, as mentioned above. Higher amplitudes of GWT in oil palm and rubber plantations compared to forests indicate a loss of buffer functions such as flood moderation, groundwater recharge, and soil water storage in the plantations. Hence, our measurements of bulk density, water infiltration, and groundwater tables point to substantial increases in surface runoff after precipitation, which could potentially increase flood frequency and intensity (Bruijnzeel 2004). This line of argument is supported by a previous study in the region, which modeled large increases in surface runoff with an increasing share of rubber and oil palm plantations in a given watershed (Tarigan et al. 2018). Although our water level data from the Tembesi River did not reflect villagers' observation that rainfall nowadays accumulates faster in local rivers than they remember from the past, our measurements of hydraulic soil properties and groundwater levels provide substantial indications that support this observation.

Our analysis of soil water infiltration in oil palm plantations where biodiversity enrichment has been carried out, however, suggests that tree planting and regeneration of natural vegetation could partially restore the very low infiltration capacity. Five years after the establishment of the experiment, average $\mathrm{K}_{\mathrm{fs}}$ in the enriched oil palm plantation was at least three-times higher than in oil palm monocultures. These findings are consistent with a meta-analysis across the tropics that reports on average three-fold increases of water infiltration capacity after afforestation or tree planting in agricultural fields (Ilstedt et al. 2007).

Our measurements thus provide several indications that forest conversion and subsequent alteration of soil properties may explain the measured increase in the Tembesi's water levels. However, especially in larger catchments, the interaction of land use and ecosystem processes increases in its complexity and causes with increasing catchment area (Bruijnzeel 1990, van Dijk et al. 2009). Studies from several river catchments in the tropics have shown that other processes related to land use change and subsequent changes in soil properties, e.g., sedimentation, road construction, missing buffer zones, or illegal gold mining have the potential to further increase river water levels (Allan 2004, Ziegler et al. 2006, Wantzen and Mol 2013, Carlson et al. 2014, Luke et al. 2017). These above-mentioned processes are also found in the Tembesi catchment area and, with the relatively large extent of the river, this 
myriad of complex land use changes and related interactions may therefore further contribute to the observed increases in river water level.

Increases in the Tembesi river water levels in both the dry and rainy seasons might be explained by the complexity of interacting ecosystem processes. In the case of reduced water infiltration capacity of soils coupled with high (evapo)transpiration rates in oil palm monoculture plantations (Manoli et al. 2018), a reduction of water levels in rivers during the dry season might be expected (Bruijnzeel 1990). Indications for such changes were suggested for oil-palm-dominated landscapes by Merten et al. (2016). Rubber plantations, on the other hand, exhibit lower (evapo)transpiration rates in smallholder-dominated cultivation systems in Jambi (Röll et al. 2019). Therefore, the impact of land conversion on the river water level in larger watersheds with mixed land use systems may be less discernible.

\section{Potential contributions of wetland conversion and water infrastructure to changing flooding regimes}

Despite their important ecological role (Bhowmik 2020), wetlands have often been described and treated as wastelands and hence converted into other land use types (Barbier et al. 1997). Our land use change analysis indicates a much higher rate of forest conversion in wetland areas compared to well-drained sites. According to interview data, this land use change can be explained by both governmentally planned plantation establishment as well as market-driven expansion of oil palm plantation into marginal areas. This trend of oil palm plantations expanding into wetlands areas has also been reported in other regions across Indonesia and Malaysia (Abram et al. 2014, Guillaume et al. 2016, Schoneveld et al. 2019).

Because of plantation expansion into wetland areas, but also because of the reported increases in flood frequency and intensity, flood control infrastructure such as dams and drainage channels have recently been installed across all our case study villages. Although we cannot quantify to what extent such infrastructure has contributed to an alteration of flooding regimes at the landscape level, our interview partners reported that the construction of flood control dams, water pumps, and drainage gates contribute to a redistribution of floodwaters at the local scale. Such developments are considered 
particularly sensitive because government representatives during interviews confirmed that the construction of water infrastructure often happens without legal notice. Accordingly, the first author observed the emergence of social conflicts.

Our interview data as well as observations in the field show that most of the studied wetland areas were managed by or with the support of private companies, external investors, or more well-off farmers. Likewise, Schoneveld et al. (2019) and Kelley and Prabowo (2019) show that plantation development on peat soils and flood prone riverbanks in Indonesia was mainly realized by more well-off farmers, political elites, and private companies that adopted more industrialized land use operations. This concentration of companies and local elites in wetland areas, together with the already mentioned conflicts over water infrastructure, creates a risk of an increasingly unequal distribution of flood damage. Surprisingly, to our knowledge, no study linking oil palm expansion to increasing flood frequency and intensity has yet paid attention to the role of infrastructure in changing flooding regimes or to the associated social impacts.

The large-scale expansion of plantations into wetland areas may also have contributed to changing flooding regimes by reducing the ecohydrological functioning of these ecosystems. Review studies suggest that lowland wetlands may substantially reduce or delay flood events (Bullock and Acreman 2003, Acreman and Holden 2013, Mitsch and Gosselink 2015). Anthropogenic activity in wetlands strongly affects local river systems because of frequent lateral water exchange between rivers and wetlands (Junk et al. 1989, Junk and Wantzen 2004). Although no data on wetland hydrology were available for the Tembesi watershed, the drainage and burning of large areas of peatlands in the watershed (Uryu et al. 2010, NASA FIRMS 2019) is particularly indicative of a degradation of local ecohydrological functions. Drainage and burning of peat soils is known to alter their physical properties, resulting in peat subsidence and compaction, thus reducing the water absorption of peat swamps (Andriesse 1988, Page et al. 2006, Wösten et al. 2008, Evers et al. 2017). Moreover, the subsidence of peat soils is considered to progressively lengthen periods of inundation (Wösten et al. 2006, Hooijer et al. 2015, Sumarga et al. 2016).

\subsubsection{CONCLUSION AND FINAL REFLECTIONS}

Our analysis showed that the observed and measured increase in flood frequency and intensity within the Tembesi River catchment area is most likely driven by land use change 
from forests to monoculture plantations. This development appears to be related to soil compaction, decreasing water infiltration rates, and, therefore, higher surface runoff. It might further be aggravated by the expansion of oil palm plantations into wetland areas and the subsequent construction of drainage and flood control infrastructure.

Our study illustrates how interrogating local ecological knowledge and integrating it with multidisciplinary scientific measurements can drive forward problem-centered research on the linkage between land use change and flooding. This study benefited from data integration in three important ways. First, local people's reports of changes in flooding regimes following land conversion, draw our attention to a problem of environmental change previously not accounted for by our research project. We thus build upon local people's ecological knowledge to then interrogate datasets from different disciplines, whether they provide indications confirming villagers' observations and evaluations or not. None of the data analyzed were initially collected for the purposes of studying flooding, and hydrological data provided by the provincial government in Jambi remain scarce and often incomplete. Despite this, the analyzed data provided substantial indications that support people's claims that land use change alters local flooding regimes. The villagers' observations and evaluations matched well with our measurements of extreme river water levels and altered hydraulic soil properties in monoculture plantations. In data-poor regions, such an integration of multidisciplinary datasets may thus help us to gain insights into socially relevant research topics that are otherwise neglected.

Second, villagers' observations of changing flooding regimes, such as increases in the frequency of flood events or more rapidly rising water levels after rainfall, also helped us to define what indicators to look for in local water level data. As a result, our problembased research approach pointed out significant gaps in our data, which, by analyzing water level data alone, might not have appeared as a gap at all. Although the predictability of flood events appears to be a major concern for local farmers in Jambi, our analyzed data does not mirror seasonal shifts in flood events and only small shifts in seasonal rainfall. Reports of shifting seasonal rainfall patterns, however, have been common across different areas in Jambi Province, and a decreasing predictability of floods has also been reported in other areas with rapid land use change (Leimona et al. 2015, Kelley and Prabowo 2019). This mismatch points to a need for more fine-scaled spatial and temporal monitoring of 
water levels and precipitation in the area to improve our understanding of the complex linkages between river discharge, land use change, and climate change.

Finally, the integration of local ecological knowledge draws our attention to the multiplicity of processes that influence the occurrence of flooding. Our study reveals that the construction of drainage or flood control infrastructure has aggravated changes in local flooding regimes, thus generating new social conflicts. Newly installed infrastructure was observed to redistribute floodwaters at the local level and thus to play a crucial role in the mediation of the social impacts of flooding. Surprisingly, the role of technical infrastructure in mediating water flows has received little scientific attention in studies connecting land use change with changing flooding regimes. More studies are needed to assess and monitor the hydrological impacts of such water management practices, as well as the social and economic relations that shape these practices.

\section{ACKNOWLEDGMENTS}

This publication was funded by the Deutsche Forschungsgemeinschaft (DFG, German Research Foundation), project number 192626868, in the framework of the collaborative German-Indonesian research project CRC 990 (SFB): “EFForTS, Ecological and Socioeconomic Functions of Tropical Lowland Rainforest Transformation Systems (Sumatra, Indonesia)" (http://www.uni-goettingen.de/crc990). We thank the EFForTS subproject A05 for contributing additional data to complete the bulk density dataset, as well as Imke Schulze Kalthoff (née Rödel) and Yvonne Kunz for contributing interview data on land use history and management of wetlands areas. We further thank Jasper Knieling for conducting the land use change analysis using ArcMap. We thank Edgar Tunsch, Marek Peksa, Malte Puhan, Frank Tiedemann, and Dietmar Fellert for their technical support. We would also like to acknowledge PT Humusindo, PTPN6, and the smallholder plot owners for allowing us to perform measurements on the plantations as well as all interview partners for sharing their knowledge and perspectives on the research topic. We greatly thank all our Indonesian field assistants who made the extensive field work possible: Agustina Siregar, Yossy Delfitri, Yohana Manurung, Winda Januarista, Basri, Bayu, Darwis, Ardian, and Amrina. Terimakasih banyak! We would also like to thank our Indonesian counterparts for their assistance during field work. Finally, we thank two anonymous reviewers for helping to improve the quality of this article. 


\section{AUTHOR CONTRIBUTIONS}

JM, CS, MD, HF, LF, DH, NH, AK, EP designed the study. JM, CS, NH, FO, AH, JK, DCZ contributed data to the manuscript. JM, CS, NH, AR, EP performed data analysis and interpretation. JM and CS prepared the manuscript. NH, AR, EP contributed to writing the manuscript. JM, CS critically revised the manuscript. All authors discussed the results and commented on the manuscript.

\section{REFERENCES}

Abram, N. K., P. Xofis, J. Tzanopoulos, D. C. MacMillan, M. Ancrenaz, R. Chung, L. Peter, R. Ong, I. Lackman, B. Goossens, L. Ambu, and A. T. Knight. 2014. Synergies for improving oil palm production and forest conservation in floodplain landscapes. PloS One 9(6): e95388. https://doi.org/10.1371/journal.pone.0095388

Acreman, M., and J. Holden. 2013. How wetlands affect floods. Wetlands 33(5):773-786. https://doi.org/10.1007/s13157-013-0473-2

Adam, F., M. Mönks, T. Esch, and M. Datcu. 2018. Cloud removal in high resolution multispectral satellite imagery: comparing three approaches. Proceedings 2(7):353. https://doi.org/10.3390/ecrs-2-05166

Adnan, N. A., and P. M. Atkinson. 2011. Exploring the impact of climate and land-use changes on streamflow trends in a monsoon catchment. International Journal of Climatology 31(6):815-831. https://doi.org/10.1002/joc.2112

Ahamed, A., and J. D. Bolten. 2017. A MODIS-based automated flood monitoring system for southeast asia. International Journal of Applied Earth Observation Geoinformation 61:104-117. https://doi.org/10.1016/j.jag.2017.05.006

Aikenhead, G. S., and M. Ogawa. 2007. Indigenous knowledge and science revisited. Cultural Studies of Science Education 2(3):539-620. https://doi.org/10.1007/s11422-007-9067-8

Alila, Y., P. K. Kuraś, M. Schnorbus, and R. Hudson. 2009. Forests and floods: a new paradigm sheds light on age-old controversies. Water Resources Research 45(8):249. https://doi.org/10.1029/2008WR007207

Allan, J. D. 2004. Landscapes and Riverscapes: the influence of land use on stream ecosystems. Annual Review of Ecology, Evolution, and Systematics 35(1):257-284. https://doi.org/10.1146/annurev.ecolsys.35.120202.110122

Allen, K., M. D. Corre, S. Kurniawan, S. R. Utami, and E. Veldkamp. 2016. Spatial variability surpasses land-use change effects on soil biochemical properties of converted lowland landscapes in Sumatra, Indonesia. Geoderma 284: 42-50. https://doi.org/10.1016/j.geoderma.2016.08.010

Alvarenga, L. A., C. R. de Mello, A. Colombo, and L. A. Cuartas. 2017. Hydrologic impacts due to the changes in riparian buffer in a headwater watershed. CERNE 23(1):95-102. https://doi.org/10.1590/01047760201723012205

Andriesse, J. P. 1988. Nature and Management of Tropical Peat Soils. FAO Soils Bulletin 59.

Antara Jambi, editor. 12th March 2017. Jambi berstatus siaga III banjir. [online] URL: https://jambi.antaranews.com/berita/318040/jambi-berstatus-siaga-iii-banjir [accessed 19th July 2019].

Ban, H. J., Y. J. Kwon, H. Shin, H. S. Ryu, and S. Hong. 2017. Flood monitoring using satellite-based RGB composite imagery and Refractive Index Retrieval in visible and near-infrared bands. Remote Sensing 9(4):313. https://doi.org/10.3390/rs9040313

Batanghari Watershed Office (BWS Sumatera VI), editor. 2016. Laporan akuntabilitas kinerja instansi pemerintah. [online] URL: https://bwssumvi.org/lakip-2016/ [accessed 30th July 2019]. 
Barbier, E. B., M. Acreman, and D. Knowler. 1997. Economic valuation of wetlands. A guide for policy makers and planners. Ramsar Convention Bureau, Glad, Switzerland.

Berger, R. 2015. Now I see it, now I don't: researcher's position and reflexivity in qualitative

Research. Qualitative Research 15(2): 219-234. https://doi.org/10.1177/1468794112468475

Berkes, F., J. Colding, and C. Folke. 2000. Rediscovery of traditional ecological knowledge as adaptive management. Ecological Applications 10(5):1251-1262. http://dx.doi.org/10.1890/10510761(2000)010[1251:roteka]2.0.co;2

Bernard, H. R. 2011. Research Methods in Anthropology: Qualitative and Quantitative Approaches. AltaMira Press, Lanham, USA, fourth edition.

Bhowmik, S. 2020. Ecological and Economic Importance of Wetlands and Their Vulnerability: A Review. Page 95-112 in Rathoure, A. K., and P.B. Chauhan, editors. Current State and Future Impacts of Climate Change on Biodiversity. IGI Global. Hershey, USA. https://doi.org/10.4018/978-1-7998-1226-5

Biagioni, S., V. Krashevska, Y. Achnopha, A. Saad, S. Sabiham, and H. Behling. 2015. 8000 years of vegetation dynamics and environmental changes of a unique inland peat ecosystem of the Jambi province in central Sumatra, Indonesia. Palaeogeography, Palaeoclimatology, Palaeoecology 440:813-829. https://doi.org/10.1016/j.palaeo.2015.09.048

de Blécourt, M., R. Brumme, J. Xu, M. D. Corre, and E. Veldkamp. 2013. Soil carbon stocks decrease following conversion of secondary forests to rubber (Hevea brasiliensis) plantations. PloS One 8(7):e69357. https://doi.org/10.1371/journal.pone.0069357

Badan Penangulan Bencana Nasional (BPBN). 2019. Data Kejadian Bencana Banjir. [online] URL: http://geospasial.bnpb.go.id/pantauanbencana/data/databanjirall.php [accessed 2nd May 2020].

Bohensky, E. L., and Y. Maru. 2011. Indigenous knowledge, science, and resilience: what have we learned from a decade of international literature on "integration"? Ecology and Society 16(4):6. http://dx.doi.org/10.5751/ES-04342-160406

BPS (Badan Pusat Statistik) Indonesia (Statistics Indonesia), editor. 2018. Luas tanaman perkebunan menurut provinsi. [online] URL: https://www.bps.go.id/subject/54/perkebunan.html\#subjekViewTab6 [accessed 30th July 2019].

Bradshaw, C. J. A., N. S. Sodhi, K. S.-H. Peh, and B. W. Brook. 2007. Global evidence that deforestation amplifies flood risk and severity in the developing world. Global Change Biology 13(11):2379-2395. https://doi.org/10.1111/j.1365-2486.2007.01446.x

Bruijnzeel, L. A. 1990. Hydrology of moist forests and the effects of conversion: a state of knowledge review. Free University, Amsterdam, The Netherlands.

Bruijnzeel, L. A. 2004. Hydrological functions of tropical forests: not seeing the soil for the trees? Agriculture, Ecosystems and Environment 104(1):185-228. https://doi.org/10.1016/j.agee.2004.01.015

Bullock, A., and M. Acreman. 2003. The role of wetlands in the hydrological cycle. Hydrology and Earth System Sciences 7(3):358-389. https://doi.org/10.5194/hess-7-358-2003

Calder, I. R., and B. Aylward. 2006. Forest and floods: moving to an evidence-based approach to watershed and integrated flood management. Water International 31(1):87-99. https://doi.org/10.1080/02508060608691918

Carlson, K. M., L. M. Curran, A. G. Ponette-González, D. Ratnasari, Ruspita, N. Lisnawati, Y. Purwanto, K. A. Brauman, and P. A. Raymond. 2014. Influence of watershed-climate interactions on stream temperature, sediment yield, and metabolism along a land use intensity gradient in Indonesian Borneo. Journal of Geophysical Research: Biogeosciences 119(6):1110-1128. https://doi.org/10.1002/2013JG002516

Chen, H., Q. Liang, Z. Liang, Y. Liu, and S. Xie. 2018. Remote-sensing disturbance detection index to identify spatio-temporal varying flood impact on crop production. Agricultural and Forest Meteorology 269-270:180-191. https://doi.org/10.1016/j.agrformet.2019.02.002 
Chong, K. L., K. D. Kanniah, C. Pohl, and K. P. Tan. 2017. A review of remote sensing applications for oil palm studies. Geo-Spatial Information Science 20(2):184-200. https://doi.org/10.1080/10095020.2017.1337317

Clough, Y., V. V. Krishna, M. D. Corre, K. Darras, L. H. Denmead, A. Meijide, S. Moser, O. Musshoff, S. Steinebach, E. Veldkamp, K. Allen, A. D. Barnes, N. Breidenbach, U. Brose, D. Buchori, R. Daniel, R. Finkeldey, I. Harahap, D. Hertel, A. M. Holtkamp, E. Hörandl, B. Irawan, I. N. S. Jaya, M. Jochum, B. Klarner, A. Knohl, M. M. Kotowska, V. Krashevska, H. Kreft, S. Kurniawan, C. Leuschner, M. Maraun, D. N. Melati, N. Opfermann, C. Pérez-Cruzado, W. E. Prabowo, K. Rembold, A. Rizali, R. Rubiana, D. Schneider, S. S. Tjitrosoedirdjo, A. Tjoa, T. Tscharntke, and S. Scheu. 2016. Land-use choices follow profitability at the expense of ecological functions in Indonesian smallholder landscapes. Nature Communications 7:13137. https://doi.org/10.1038/ncomms13137

Dang. N. M., M. S. Babel, and H. T. Luong. 2011. Evaluation of flood risk parameters in the Day River Flood Diversion Area, Red River Delta, Vietnam. Natural Hazards 56:169-194. https://doi.org/10.1007/s11069-010-9558-x

Díaz, S., U. Pascual, M. Stenseke, B. Martín-López, R. T. Watson, Z. Molnár, R. Hill, K. M. A. Chan, I. A. Baste, K. A. Brauman, S. Polasky, A. Church, M. Lonsdale, A. Larigauderie, P. W. Leadley, A. P. E. van Oudenhoven, F. van der Plaat, M. Schröter, S. Lavorel, Y. AumeeruddyThomas, E. Bukvareva, K. Davies, S. Demissew, G. Erpul, P. Failler, C. A. Guerra, C. L. Hewitt, H. Keune, S. Lindley, and Y. Shirayama. 2018. Assessing nature's contributions to people. Science 359(6373):270-272. https//doi.org/10.1126/science.aap8826

Di Baldassare, G., J. S. Kemerink, M. Kooy, and L. Brandimarte. 2014. Floods and societies: the spatial distribution of water-related disaster risk and its dynamics. WIREs Water 1(2):133-139. https://doi.org/10.1002/wat2.1015

Dislich, C., A. C. Keyel, J. Salecker, Y. Kisel, K. M. Meyer, M. Auliya, A. D. Barnes, M. D. Corre, K. Darras, H. Faust, B. Hess, S. Klasen, A. Knohl, H. Kreft, A. Meijide, F. Nurdiansyah, F. Otten, G. Pe'er, S. Steinebach, S. Tarigan, M. H. Tölle, T. Tscharntke, and K. Wiegand. 2016. A review of the ecosystem functions in oil palm plantations, using forests as a reference system. Biological Reviews of the Cambridge Philosophical Society 92(3):1539-1569. https://doi.org/10.1111/brv.12295

Don, A., J. Schumacher, and A. Freibauer. 2011. Impact of tropical land-use change on soil organic carbon stocks - a meta-analysis. Global Change Biology 17(4):1658-1670. https://doi.org/10.1111/j.1365-2486.2010.02336.x

Drescher, J., K. Rembold, K. Allen, P. Beckschäfer, D. Buchori, Y. Clough, H. Faust, A. M. Fauzi, D. Gunawan, D. Hertel, B. Irawan, I. N. S. Jaya, B. Klarner, C. Kleinn, A. Knohl, M. M. Kotowska, V. Krashevska, V. Krishna, C. Leuschner, W. Lorenz, A. Meijide, D. Melati, M. Nomura, C. Pérez-Cruzado, M. Qaim, I. Z. Siregar, S. Steinebach, A. Tjoa, T. Tscharntke, B. Wick, K. Wiegand, H. Kreft, and S. Scheu. 2016. Ecological and socio-economic functions across tropical land use systems after rainforest conversion. Philosophical Transactions of the Royal Society B: Biological Sciences 371(1694):20150275. https://doi.org/10.1098/rstb.2015.0275

Ellison, D., C. E. Morris, B. Locatelli, D. Sheil, J. Cohen, D. Murdiyarso, V. Gutierrez, M. van Noordwijk, I. F. Creed, J. Pokorny, D. Gaveau, D. V. Spracklen, A. B. Tobella, U. Ilstedt, A. J. Teuling, S. G. Gebrehiwot, D. C. Sands, B. Muys, B. Verbist, E. Springgay, Y. Sugandi, and C. A. Sullivan. 2017. Trees, forests and water: cool insights for a hot world. Global Environmental Change 43(51):51-61. https://doi.org/10.1016/j.gloenvcha.2017.01.002

Evers, S., C. M. Yule, R. Padfield, P. O'Reilly, and H. Varkkey. 2017. Keep wetlands wet: the myth of sustainable development of tropical peatlands - implications for policies and management. Global Change Biology 23(2):534-549. https://doi.org/10.1111/gcb.13422

Fabricius, C., R. Scholes, and G. Cundill. 2006. Mobilizing knowledge for integrated ecosystem assessments. In: Reid, W. V., Berkes, F., Wilbanks, R., and D. Capistrano (eds.) Bridging scales and knowledge systems: concepts and applications in ecosystem assessment. Island Press, Washington, United States of America: 165-182. 
Fearnside, P. M. 1997. Transmigration in Indonesia. Lessons from its Environmental and Social Impacts. Environmental Management 21(4):553-570.

Feintrenie, L., and P. Levang. 2009. Sumatra's rubber agroforests: advent, rise and fall of a sustainable cropping system. Small-scale Forestry 8(3):323-335. https://doi.org/10.1007/s11842-009-9086-2

Flick, U. 2016. Qualitative Sozialforschung. Rowohlt, Hamburg, Germany.

Forsyth, T. 2003. Critical political ecology: the politics of environmental science. Routledge, London, United Kingdom.

Ge, F., S. Zhu, T. Peng, Y. Zhao, F. Sielman, K. Fraedrich, X. Zhi, X. Liu, W. Tang, and L., Ji. 2019. Risks of precipitation extremes over Southeast Asia: does $1.5^{\circ} \mathrm{C}$ or $2{ }^{\circ} \mathrm{C}$ global warming make a difference? Environmental Research Letters 14:044015. https://doi.org/10.1088/17489326/aaff7e

Gilbert, R. O. 1987. Statistical methods for environmental pollution monitoring. Van Nostrand Reinhold, New York, United States of America.

Guillaume, T., M. Damris, and Y. Kuzyakov. 2015. Losses of soil carbon by converting tropical forest to plantations: erosion and decomposition estimated by $\delta^{13} \mathrm{C}$. Global Change Biology 21(9):3548-3560. https://doi.org/10.1111/gcb.12907

Guillaume, T., A. M. Holtkamp, M. Damris, B. Brümmer, and Y. Kuzyakov. 2016. Soil degradation in oil palm and rubber plantations under land resource scarcity. Agriculture, Ecosystems $\mathcal{E}$ Environment 232:110-118. https://doi.org/10.1016/j.agee.2016.07.002

Gumbricht, T., R. M Roman-Cuesta, L. Verchot, M. Herold, F. Wittmann, E. Householder, N. Herold, and D. Murdiyarso. 2017. An expert system model for mapping tropical wetlands and peatlands reveals South America as the largest contributor. Global Change Biology 23(9):35813599. https://doi.org/10.1111/gcb.13689

Hansen, M. C., P. V. Potapov, R. Moore, M. Hancher, S. A. Turubanova, A. Tyukavina, D. Thau, S. V. Stehman, S. J. Goetz, T. R. Loveland, A. Kommareddy, A. Egorov, L. Chini, C. O. Justice, and J. R. G. Townshend. 2013. High-resolution global maps of 21st-century forest cover change. Science 342(6160):850-853. https://doi.org/10.1126/science.1244693

Hassler, S. K., B. Zimmermann, M. van Breugel, J. S. Hall, and H. Elsenbeer. 2011. Recovery of saturated hydraulic conductivity under secondary succession on former pasture in the humid tropics. Forest Ecology and Management 261(10):1634-1642. https://doi.org/10.1016/j.foreco.2010.06.031.

Hofer, T., and B. Messerli. 2006. Floods in Bangladesh: History, dynamics and rethinking the role of the Himalayas. United Nations University Press, Tokyo, Japan.

Hooijer, A., R. Vernimmen, M. Visser, and N. Mawdsley. 2015. Flooding projections from elevation and subsidence models for oil palm plantations in the Rajang Delta peatlands, Sarawak, Malaysia. Deltares Report $1207384 . \quad$ [online] URL: https://www.deltares.nl/app/uploads/2015/06/Rajang-Delta-Peatland-Subsidence-FloodingDeltares-2015.pdf [accessed, 30th July 2019].

Houde, N. 2007. The six faces of traditional ecological knowledge: challenges and opportunities for Canadian co-management arrangements. Ecology and Society 12(2):34. https://doi.org/10.5751/ES-02270-120234

Ilstedt, U., A. Malmer, E. Verbeeten, and D. Murdiyarso. The effect of afforestation on water infiltration in the tropics: a systematic review and meta-analysis. Forest Ecology and Management 251(1-2):45-51. https://doi.org/10.1016/j.foreco.2007.06.014

Junk, W., P. B. Bayley, and R.E. Sparks. 1989. The flood pulse concept in river-floodplain

systems. Pages 110-127 in Dodge, D. P., editor. Proceedings of the International Large River Symposium (LARS). Canadian Special Publication of Fisheries and Aquatic Sciences 106:110-127.

Junk, W. J., and K. M. Wantzen, 2004. The flood pulse concept: new aspects, approaches and applications-an update. Pages 117-140 in Welcomme, R. L., and T. Petr, editors. Proceedings of the Second International Symposium on the Management of Large Rivers for Fisheries, Food and Agriculture Organization of the United Nations (FAO) and the Mekong River Commission (MRC), 
Volume 2. FAO Regional Office for Asia and the Pacific, Bangkok, Thailand. RAP Publication 2004/17: 117-140.

Kelley, L. S., and A. Prabowo. 2019. Flooding and Land-use change in Southeast Sulawesi, Indonesia. Land 8(9):139. https://doi.org/10.3390/land8090139

Klubnikin, K., C. Annett, M. Cherkasova, M. Shishin, and I. Fotieva. 2000. The sacred and the scientific: traditional ecological knowledge in Siberian river conservation. Ecological Applications 10:1296-1306. 0761(2000)010[1296:TSATST]2.0.CO

Krüger, T., C. Maynard, G. Carr, A. Bruns, E. N. Mueller, and S. Lane. 2016. A transdisciplinary account of water research. WIREs Water 3(3):369-389. https://doi.org/10.1002/wat2.1132

Kunz, Y. 2016. Landscape transformation in Jambi province, Sumatra. An analysis of land tenure regulations under translational dynamics. Doctoral thesis. Georg-August University of Goettingen, Goettingen, Germany. [online] URL: https://ediss.uni-goettingen.de/handle/11858/00-17350000-0028-875A-A [accessed 2nd May 2020].

Kwak, Y. 2017. Nationwide flood monitoring for disaster risk reduction using multiple satellite data. International Journal of Geo-Information 6(203). https://doi.org/10.3390/ijgi6070203

Langill, J. C., and C. Abizaid. 2019. What is a bad flood? Local perspectives of extreme floods in the Peruvian Amazon. Ambio 2019. https://doi.org/10.1007/s13280-019-01278-8

Larsen, R. K., N. Jiwan, A. Rompas, J. Jenito, M. Osbeck, and A. Tarigan. 2014. Towards 'hybrid accountability' in EU biofuels policy? Community grievances and competing water claims in the Central Kalimantan oil palm sector. Geoforum 54:295-305. http://dx.doi.org/10.1016/j.geoforum.2013.09.010

Laumonier, Y., 1997. The vegetation and physiography of Sumatra. Kluwer Academic Publishers, Dordrecht, The Netherlands.

Lawrence, D., and K. Vandecar. 2015. Effects of tropical deforestation on climate and agriculture. Nature Climate Change 5(1):27-36. https://doi.org/10.1038/nclimate2430

Leimona, B., B. Lusiana, M. van Noordwijk, E. Mulyoutami, A. Ekadinata, and S. Amaruzaman. 2015. Boundary work: knowledge co-production for negotiating payment for watershed services in Indonesia. Ecosystem Services 15:45-62. https://doi.org/10.1016/j.ecoser.2015.07.002

Lele, S. 2009. Watershed services of tropical forests: from hydrology to economic valuation to integrated analysis. Current Opinion in Environmental Sustainability 1(2):148-155. https://doi.org/10.1016/j.cosust.2009.10.007

Lele, S., and A. Kurien. 2011: Interdisciplinary analysis of the environment: insights from tropical forest research. Environmental Conservation 38(2):211-233. https://doi.org/10.1017/S037689291100018X

Li, H., Y. Ma, W. Liu, and W. Liu. 2012. Soil changes induced by rubber and tea plantation establishment: comparison with tropical rain forest soil in Xishuangbanna, SW China. Environmental Management 50(5):837-848. https://doi.org/10.1007/s00267-012-9942-2

Locatelli, B., and R. Vignola. 2009. Managing watershed services of tropical forests and plantations: can meta-analyses help? Forest Ecology and Management 258(9):1864-1870. https://doi.org/10.1016/j.foreco.2009.01.015

Luke, S. H., H. Barclay, K. Bidin, V. K. Chey, R. M. Ewers, W. A. Foster, A. Nainar, M. Pfeifer, G. Reynolds, E. C. Turner, R. P. D. Walsh, and D. C. Aldridge. 2017. The effects of catchment and riparian forest quality on stream environmental conditions across a tropical rainforest and oil palm landscape in Malaysian Borneo. Ecohydrology 10:e1827. https://doi.org/10.1002/eco.1827

Maggioni, V., and C. Massari. 2018. On the performance of satellite precipitation products in riverine flood modeling: A review. Journal of Hydrology 558:214-224. https://doi.org/10.1016/j.jhydrol.2018.01.039

Malaysian Department of Irrigation and Drainage (MDID), editor. 1989. Variation of Rainfall with Area in Peninsular Malaysia. Sungai Tekam Experimental Basin Final Report, July 1977 to June 1986. Water Resources Publication 20. [online] URL: 
https://www.water.gov.my/jps/resources/auto\%20download\%20images/58746b0be2b8a.pd f [accessed 29th April 2020].

Manoli, G., A. Meijide, N. Huth, A. Knohl, Y. Kosugi, P. Burlando, J. Ghazoul, and S. Fatichi. 2018. Ecohydrological changes after tropical forest conversion to oil palm. Environmental Research Letters 13(6):064035. https://doi.org/10.1088/1748-9326/aac54e

Mantel, S., H. Wösten, and J. Verhagen. 2007. Biophysical Land Suitability for Oil Palm in Kalimantan, Indonesia. Report 2007/01, ISRIC - World Soil Information, Alterra, Plant Research International, Wageningen UR, Wageningen, The Netherlands.

Margono, B. A., P. V. Potapov, S. Turubanova, F. Stolle, and M. C. Hansen. 2014. Primary forest cover loss in Indonesia over 2000-2012. Nature Climate Change 4(8):730-735. https://doi.org/10.1038/nclimate2277

Margono, B. A., A. B. Usman, Budiharto, and R. A. Sugardiman. 2016. Indonesia's forest resource monitoring. Indonesian Journal of Geography 48(1):7-20. https://doi.org/10.22146/ijg.12496

Martens, K. 2017. Adaption strategies of oil palm smallholders towards certification schemes.

A micro scale approach from Jambi, Sumatra. Master thesis. Georg-August University of Goettingen, Goettingen, Germany. [online] URL: https://www.unigoettingen.de/de/master+studies+g\%c3\%b6ttingen+\%282017\%29/564021.html [accessed 30th July 2019].

Mayring, P. 2000. Qualitative Content Analysis. Forum: Qualitative Social Research 1(2):20. [online] URL: http://nbn-resolving.de/urn:nbn:de:0114-fqs0002204 [accessed 30th July 2019]

Metro Jambi, editor. 17th March 2017: Debit air sungai Batanghari mulai surut. [online] URL: https://metrojambi.com/read/2017/03/17/19543/debit-air-sungai-batanghari-mulai-susut [accessed 30th July 2019].

Minister of Public Works (Menteri Pekerjaan Umum), Republic of Indonesia, editor. 2012. Keputusan Menteri PU Nomor 51/KPTS/M/2012 tentang Pola Pengelolaan Sumber Daya Air Wilayah Sungai Batanghari. [online] URL: http://sda.pu.go.id/produk/mfhandler.php?file=2012_Pola\%20PSDA\%20Batanghari.pdf\&ta ble=newsmain\&field=Attachment\&pageType=list\&key1=140 $\quad$ [accessed $\quad 11^{\text {th }}$ September 2019].

Mitsch, W. J., and J. G. Gosselink. 2015. Wetlands. Fifth edition. Wiley, Hobokoen, The Netherlands.

Melati, D. N. 2017. The use of remote sensing data to monitor land use systems and forest variables of the tropical rainforest landscape under transformation in Jambi Province, Sumatra, Indonesia. Doctoral Dissertation. Georg-August-University of Goettingen, Goettingen, Germany. [online] URL: http://hdl.handle.net/11858/00-1735-0000-002E-E323-E [accessed 30th July 2019].

Merten, J., A. Röll, T. Guillaume, A. Meijide, S. Tarigan, H. Agusta, C. Dislich, C. Dittrich, H. Faust, D. Gunawan, J. Hein, Hendrayanto, A. Knohl, Y. Kuzyakov, K. Wiegand, and D. Hölscher. Water scarcity and oil palm expansion: social views and environmental processes. Ecology and Society 21(2):5. http://dx.doi.org/10.5751/ES-08214-210205

Moller, H., F. Berkes, P. O. Lyver, and M. Kislalioglu. 2004. Combining science and traditional ecological knowledge: monitoring populations for co-management. Ecology and Society 9(3):2. http://dx.doi.org/10.5751/ES-00675-090302

Nadasdy, P. 1999. The politics of TEK: power and the "integration" of knowledge. Arctic Anthropology 36:1-18.

Najibi, N., and N. Devineni. 2018. Recent trends in the frquency and duration of global floods. Earth System Dynamics 9: 757-783. https://doi.org/10.5194/esd-9-757-2018

NASA FIRMS, editor. 2019. MODIS Active Fires. [online] URL: www.globalforestwatch.org [accessed on 9th July 2019].

Notti, D., D. Giordan, F. Caló, A. Pepe, F. Zucca, and J. P. Galve. 2018. Potential and limitations of open satellite data for flood mapping. Remote Sensing 10:1673. https://doi.org/10.3390/rs10111673 
Obidzinski, K., R. Andriani, H. Komarudin, and A. Andrianto. 2012. Environmental and social impacts of oil palm plantations and their implications for biofuel production in Indonesia. Ecology and Society 17(1):25. http://dx.doi.org/10.5751/ES-04775-170125

Pachepsky, Y., and Y. Park. 2015. Saturated hydraulic conductivity of US soils grouped according to textural class and bulk density. Soil Science Society of America Journal 79(4):1094-1100. https://doi.org/10.2136/sssaj2015.02.0067

Page, S. E., J. O. Rieley, and R. Wiist. 2006. Lowland tropical peatlands of Southeast Asia. Page 145172 in Martini, I.P., Martinez Cortizas, A. and W. Chesworth, editors. Peatlands: evolution and records of environmental and climate changes. Development in Earth's Surface Processes 9. Elsevier, Amsterdam, Netherlands. https://10.1016/S0928-2025(06)09007-9

Pattison, I., and S. N. Lane. 2012. The link between land-use management and fluvial flood risk. Progress in Physical Geography 36(1):72-92. https://doi.org/10.1177/0309133311425398

Provincial Government Jambi (Pemertina Provinsi Jambi), editor. 2016. Rencana Pembangunan Jangka Menengah Daerah (RPJMD) Provinsi Jambi 2016-2021. [online] URL: http://jdih.jambiprov.go.id/fileperaturan/6081Perda_NO.7RPJMD_2016-2021.pdf [accessed 11th September 2019].

Persson, J., E. L. Johansson, and L. Olsson. 2018. Harnessing local knowledge for scientific knowledge production: challenges and pitfalls within evidence-based sustainability studies. Ecology and Society 23(4):38. https://doi.org/10.5751/ES-10608-230438

Pierotti, R., and D. Wildcat. 2000. Traditional ecological knowledge: the third alternative (commentary). Ecological Applications 10(5):1333-1340. https://doi.org/10.1890/10510761(2000)010[1333:TEKTTA]2.0.CO;2

Ribot, J. 2014. Cause and response: vulnerability and climate in the Anthropocene. Journal of Peasant Studies 41(5):667-705. https://doi.org/10.1080/03066150.2014.894911

Ramsar Convention Secretariat, editor. 2016. An Introduction to the Convention on Wetlands (previously The Ramsar Convention Manual). Gland, Switzerland. [online] URL: https://www.ramsar.org/sites/default/files/documents/library/handbook1_5ed_introductio ntoconvention_e.pdf [accessed 30th July 2019].

Rödel, I. 2018. Smallholders' sustainability perceptions vs. performance in the context of Indonesian palm oil. How do international sustainability criteria influence local discourses and practices in rural Sumatra? Master thesis. Georg-August University of Goettingen, Goettingen, Germany. [online] URL: https://www.unigoettingen.de/de/master+studies+g\%c3\%b6ttingen+\%282018\%29/583178.html [accessed 30th July 2019].

Röll, A., F. Niu, A. Mejide, J. Ahongshangbam, M. Ehbrecht, T. Guillaume, D. Gunawan, A. Hardanto, Hendrayanto, D. Hertel, M. M. Kotowska, H. Kreft, Y. Kuzyakov, C. Leuschner, M. Nomura, A. Polle, K. Rembold, J. Sahner, D. Seidel, D. C. Zemp, A. Knohl, and D. Hölscher. 2019. Transpiration on the rebound in lowland Sumatra. Agricultural and Forest Meteorology 274:160-171. https://doi.org/10.1016/j.agrformet.2019.04.017

Roni, P., editor. 2005: Monitoring stream and water restoration. American Fisheries Society, Bethesda, Maryland.

Saberwal, V. K. 1998. Science and the desiccationist discourse of the 20th century. Environment and History 4(3):309-343. https://doi.org/10.3197/096734098779555547

Sarigah, Radesman. 5th March 2019. Banjir, Puluhan Hektare Sawah di Sarolangun Gagal Panen. [online] URL: https://www.beritasatu.com/nasional/541260/banjir-puluhan-hektare-sawahdi-sarolangun-gagal-panen [accessed 30th July 2019].

Schoneveld, G. C., D. Ekowati, A. Andrianto, and S. van der Haar. 2019. Modeling peat- and forestland conversion by oil palm smallholders in Indonesian Borneo. Environmental Research Letters 14(1):14006. https://doi.org/10.1088/1748-9326/aaf044

Spracklen, D. V., J. C. A. Baker, L. Garcia-Carreras, and J. H. Marsham. 2018. The Effects of Tropical Vegetation on Rainfall. Annual Review of Environment and Resources 43:193-218. 
Stringer, L. C., and M. S. Reed. 2007. Land degradation assessment in Southern Africa. Integrating local and scientific knowledge bases. Land Degradation \& Development 18(1):99-116. https://doi.org/10.1002/ldr.760

Sumarga, E., L. Hein, A. Hooijer, and R. Vernimmen. 2016. Hydrological and economic effects of oil palm cultivation in Indonesian peatlands. Ecology and Society 21(2):52 http://dx.doi.org/10.5751/ES-08490-210252

Tan-Soo, J.-S., N. Adnan, I. Ahmad, S. K. Pattanayak, and J. R. Vincent. 2016. Econometric evidence on forest ecosystem services: deforestation and flooding in Malaysia. Environmental and Resource Economics 63(1):25-44. https://doi.org/10.1007/s10640-014-9834-4

Tarigan, S., K. Wiegand, and B. Slamet. 2018. Minimum forest cover required for sustainable water flow regulation of a watershed. a case study in Jambi Province, Indonesia. Hydrology and Earth System Sciences 22(1):581-594. https://doi.org/10.5194/hess-22-581-2018

Tempo.co, editor. 23rd July 2010: Alih Fungsi Sawah Ancam Ketahanan Pangan Jambi. [online] URL: https://nasional.tempo.co/read/265784/alih-fungsi-sawah-ancam-ketahanan-pangan-jambi [accessed 30th July 2019].

Tengö, M., E. S. Brondizio, T. Elmqvist, P. Malmer, and M. Spierenburg. 2014. Connecting Diverse Knowledge Systems for Enhanced Ecosystem Governance: The Multiple Evidence Base Approach. Ambio 43(5):579-591. https://doi.org/10.1007/s13280-014-0501-3

Teuscher, M., A. Gérard, U. Brose, D. Buchori, Y. Clough, M. Ehbrecht, D. Hölscher, B. Irawan, L. Sundawati, M. Wollni, and Kreft, H. Experimental biodiversity enrichment in oil-palmdominated landscapes in Indonesia. Frontiers in Plant Science 7:1538. https://doi.org/10.3389/fpls.2016.01538.

The Jakarta Post, editor. 31st December 2014. Floods ruin thousands of hectares of crops. [online] URL: $\quad$ https://www.thejakartapost.com/news/2014/12/31/floods-ruin-thousands-hectarescrops.html [accessed 30th July 2019].

Thorén, H., and J. Persson. 2013. The philosophy of interdisciplinarity: sustainability science and problem-feeding Journal for General Philosophy of Science 44(2):337-355. https://doi.org/10.1007/s10838-013-9233-5

Thorén, H., and S. Stahlhammer. 2018. Ecosystem services between integration and economic imperialism. Ecology and Society 23(4):44. https://doi.org/10.5751/ES-10520-230444

Townend, J. 2004. Practical Statistics for Environmental and Biological Scientists. Third edition. Chichester, England: John Wiley \& Sons, LTD.

Tran, P., F. Marincioni, and R. Shaw. 2010. Catastrophic flood and forest cover change in the Huong river basin, central Viet Nam: a gap between common perceptions and facts. Journal of Environmental Management 91(11):2186-2200. https://doi.org/10.1016/j.jenvman.2010.05.020

Usher, P. J. 2000. Traditional ecological knowledge in environmental assessment and management. Arctic 53(2):183-193. http://doi.org/10.14430/arctic849

van Dijk, A. I., M. van Noordwijk, I. R. Calder, L. A. Bruijnzeel, J. A. A. P. Schellekens, and N. A. Chappell. 2009. Forest-flood relation still tenuous - comment on 'Global evidence that deforestation amplifies flood risk and severity in the developing world' by C. J. A. Bradshaw, N.S. Sodi, K. S.-H. Peh and B.W. Brook. Global Change Biology 15(1):110-115. https://doi.org/10.1111/j.1365-2486.2008.01708.x

Wahyunto, R. S., and H. Subagjo. 2003. Peta Luas Sebaran Lahan Gambut dan Kandungan Karbon di Pulau Sumatera / Maps of peatland distribution and carbon content in Sumatera, 19902002. Wetlands International Indonesia Programme and Wildlife Habitat Canada (WHC), Bogor, Indonesia,

Waite, P. A., B. Schuldr, R. Link, N. Breidenbach, T. Triadiati, N. Hennings, Saad, A., and C. Leuschner. 2019. Soil moisture regime and palm height influence embolism resistance in oil palm. Tree Physiology 39(10): 1696-1712. https://doi.org/10.1093/treephys/tpz061

Walters, B. B., and A. P. Vayda. 2009. Event ecology, causal historical analysis, and humanenvironment research. Annals of the Association of American Geographers 99(3):534-553. https://doi.org/10.1080/00045600902931827 
Wang, H., Z. Yang, Y. Saito, J.P. Liu, and X. Sun. 2006. Interannual and seasonal variation of the Huanghe (Yellow River) water discharge over the past 50 years: Connections to impacts from ENSO events and dams. Global and Planetary Change 50:2012-225. https://doi.org/10.1016/j.gloplacha.2006.01.005

Wang. L., X. Chen, Q. Shao, and Y. Li. 2015. Flood indicators and their clustering features in Wujiang River, South China. Ecological Engineering 76:66-74. http://dx.doi.org/10.1016/j.ecoleng.2014.03.018

Wantzen, K., and J. Mol. 2013. Soil Erosion from Agriculture and Mining: A Threat to Tropical Stream Ecosystems. Agriculture 3:660-683. https://doi.org/10.3390/agriculture3040660

Wells, J. A., K. A. Wilson, N. K. Abram, M. Nunn, D. L. A. Gaveau, R. K. Runting, N. Tarniati, K. L. Mengersen, and E. Meijaard. 2016. Rising floodwaters: mapping impacts and perceptions of flooding in Indonesian Borneo. Environmental Research Letters 11(6):064016. https://doi.org/10.1088/1748-9326/11/6/064016

Wösten, J. H. M., J. Van Den Berg, P. van Eijk, G. J. M. Gevers, W. B. J. T. Giesen, A. Hooijer, A. Idris, P. H. Leenman, D. Rais, Satriadi, C. Siderius, M. J. Silvius, N. Suryadiputra, and I. T. Wibisono. 2006. Interrelationships between Hydrology and Ecology in Fire Degraded Tropical Peat Swamp Forests. International Journal of Water Resources Development 22 (1):157174. https://doi.org/10.1080/07900620500405973

Wösten, J. H. M., E. Clymans, S. E. Page, J. O. Rieley, and S. H. Limin. 2008. Peat-water interrelationships in a tropical peatland ecosystem in Southeast Asia. CATENA 73(2):212224. https://doi.org/10.1016/j.catena.2007.07.010

Uryu, Y., E. Purastuti, Y. Laumonier, Sunarto, Setiabudi, A. Budiman, K. Yulianto, A. Sudibyo, O. Hadian, D. A. Kosasih, and A. Stüwe. 2010. Sumatra's forests, their wildlife and the climate windows in time: 1985, 1990, 2000 and 2009. Technical Report. WWF Indonesia, Jakarta, Indonesia.

Yeung, H. 1997. Critical realism and realist research in human geography: a method or a philosophy in search of a method? Progress in Human Geography 21(1):51-74. https://doi.org/10.1191/030913297668207944

Zhang, Q., C.-Y. Xu, S. Becker, Z. X. Zhang, Y. D. Chen, and M. Coulibaly. 2009. Trends and abrupt changes of precipitation maxima in the Pearl River basin, China. Atmospheric Science Letters 10:132-144. https://doi.org/10.1002/asl.221

Zhang, X., L. Alexander, G. C. Hegerl, P. Jones, A. K. Tank, T. C. Peterson, B. Trewin, and F. W. Zwiers2011. Indices for monitoring changes in extremes based on daily temperature and precipitation data. WIREs Climate Change 2(6):851-870. https://doi.org/10.1002/wcc.147

Ziegler, A. D., J. Negishi, R. C. Sidle, P. Preechapanya, R. A. Sutherland, T. W. Giambelluca, and S. Jaiaree. 2006. Reduction of stream sediment concentration by a riparian buffer: Filtering of rad runoff in disturbed headwater basins of montane mainland Southeast Asia. Journal of Environmental Quality 35(1):151-162. https://doi.org/10.2134/jeq2005.0103 


\section{APPENDIX}

\section{Biodiversity enrichment experiment}

A 2.1-1: Information regarding the plots of the biodiversity enrichment experiment (EFForTS-BEE) where water infiltration has been measured. Details on the species composition, plot size and tree diversity are described in Teuscher et al. (2016). A: Parkia speciosa (Fabaceae); B: Archidendron pauciflorum (Fabaceae); C: Durio zibethinus (Malvaceae); D: Dyera polyphylla (Apocynaceae); E: Peronema canescens (Lamiaceae); F: Shorea leprosula (Dipterocarpaceae).

\begin{tabular}{|c|c|c|c|c|c|c|}
\hline Plot ID & Lat & Long & Plot size & $\begin{array}{l}\text { Diversity } \\
\text { Level }\end{array}$ & $\begin{array}{l}\text { Composition } \\
\text { of the } \\
\text { planted tree } \\
\text { species }\end{array}$ & $\begin{array}{l}\text { Number of } \\
\text { planted } \\
\text { trees }\end{array}$ \\
\hline 1 & -1.94162 & 103.2519 & 40 & 1 & A & 400 \\
\hline 2 & -1.94174 & 103.253 & 20 & 3 & $\mathrm{ACF}$ & 99 \\
\hline 3 & -1.9433 & 103.2518 & 20 & 2 & $\mathrm{CD}$ & 100 \\
\hline 4 & -1.94321 & 103.2532 & 10 & 1 & $F$ & 25 \\
\hline 5 & -1.94478 & 103.2518 & 40 & 1 & $\mathrm{~B}$ & 400 \\
\hline 6 & -1.94462 & 103.2532 & 5 & 1 & $\mathrm{E}$ & 6 \\
\hline 7 & -1.94469 & 103.2552 & 40 & 3 & AEF & 399 \\
\hline 8 & -1.94587 & 103.2491 & 5 & 1 & $\mathrm{~F}$ & 6 \\
\hline 12 & -1.94589 & 103.2543 & 20 & 1 & C & 100 \\
\hline 13 & -1.94591 & 103.2559 & 10 & 1 & $\mathrm{E}$ & 25 \\
\hline 17 & -1.94734 & 103.2531 & 20 & 1 & $\mathrm{~F}$ & 100 \\
\hline 22 & -1.94873 & 103.2491 & 5 & 2 & $\mathrm{BF}$ & 6 \\
\hline 24 & -1.94838 & 103.2543 & 40 & 2 & $\mathrm{CE}$ & 400 \\
\hline 26 & -1.94849 & 103.2572 & 40 & 2 & DF & 400 \\
\hline 27 & -1.94992 & 103.2464 & 10 & 2 & $\mathrm{AE}$ & 24 \\
\hline 28 & -1.95002 & 103.2478 & 5 & 1 & B & 6 \\
\hline 29 & -1.94996 & 103.249 & 40 & 3 & $\mathrm{BCD}$ & 399 \\
\hline 30 & -1.94981 & 103.253 & 20 & 1 & $\mathrm{E}$ & 100 \\
\hline 31 & -1.94997 & 103.2545 & 5 & 1 & C & 6 \\
\hline 34 & -1.95143 & 103.2451 & 10 & 2 & $\mathrm{BD}$ & 24 \\
\hline 35 & -1.95182 & 103.2466 & 40 & 0 & $\mathrm{Z}$ & 0 \\
\hline 36 & -1.95106 & 103.2477 & 20 & 2 & $\mathrm{AF}$ & 100 \\
\hline 37 & -1.95118 & 103.2488 & 10 & 0 & $\mathrm{Z}$ & 0 \\
\hline 38 & -1.95172 & 103.2504 & 20 & 1 & D & 100 \\
\hline 39 & -1.95138 & 103.2518 & 5 & 2 & AC & 6 \\
\hline 41 & -1.95267 & 103.2438 & 10 & 1 & A & 25 \\
\hline 42 & -1.95276 & 103.245 & 5 & 1 & D & 6 \\
\hline 44 & -1.95271 & 103.2478 & 5 & 3 & BEF & 6 \\
\hline 45 & -1.95307 & 103.2487 & 40 & 1 & $\mathrm{E}$ & 400 \\
\hline 46 & -1.95442 & 103.2424 & 40 & 2 & $\mathrm{AB}$ & 400 \\
\hline 47 & -1.95395 & 103.2437 & 20 & 2 & $\mathrm{BE}$ & 100 \\
\hline 48 & -1.9541 & 103.2452 & 10 & 3 & CEF & 24 \\
\hline 49 & -1.954 & 103.2466 & 40 & 1 & $\mathrm{~F}$ & 400 \\
\hline
\end{tabular}




\begin{tabular}{|l|l|l|l|l|l|l|}
\hline 50 & -1.95406 & 103.2478 & 5 & 6 & ABCDEF & 6 \\
\hline 51 & -1.95425 & 103.2491 & 20 & 1 & A & 100 \\
\hline 53 & -1.94325 & 103.2547 & 10 & control & & 0 \\
\hline 54 & -1.9512 & 103.2558 & 10 & control & & 0 \\
\hline 55 & -1.9513 & 103.2534 & 10 & control & & 0 \\
\hline 56 & -1.95505 & 103.2461 & 10 & control & & 0 \\
\hline
\end{tabular}




\section{River discharge}

A 2.1-2:Mean water level ( \pm standard deviation) at Pauh hydrological station and results of Mann-Kendall test (Mann-Kendall $\tau$ and $p$-value).

\begin{tabular}{|c|c|c|c|c|c|c|c|c|c|c|c|c|c|c|c|}
\hline \multirow{2}{*}{ Year } & \multicolumn{12}{|c|}{ Month } & \multirow{2}{*}{$\begin{array}{c}\text { Wet } \\
\text { season } \\
\text { (Oct.- } \\
\text { May) } \\
\end{array}$} & \multirow{2}{*}{$\begin{array}{c}\text { Dry } \\
\text { season } \\
\text { (Jun.- } \\
\text { Sept.) } \\
\end{array}$} & \multirow{2}{*}{ Annual } \\
\hline & Jan. & Feb. & Mar. & Apr. & May & Jun. & Jul. & Aug. & Sept. & Oct. & Nov. & Dec. & & & \\
\hline $\begin{array}{c}\text { Average } \\
(1997- \\
2016)\end{array}$ & $\begin{array}{c}7.07 \\
( \pm 2.05)\end{array}$ & $\begin{array}{c}6.90 \\
( \pm 2.24)\end{array}$ & $\begin{array}{c}6.80 \\
( \pm 2.46)\end{array}$ & $\begin{array}{c}7.25 \\
( \pm 2.17)\end{array}$ & $\begin{array}{c}6.47 \\
( \pm 1.94)\end{array}$ & $\begin{array}{c}4.92 \\
( \pm 1.50)\end{array}$ & $\begin{array}{c}4.74 \\
( \pm 1.58)\end{array}$ & $\begin{array}{c}4.48 \\
( \pm 1.29)\end{array}$ & $\begin{array}{c}4.43 \\
( \pm 1.32)\end{array}$ & $\begin{array}{c}5.08 \\
( \pm 1.43)\end{array}$ & $\begin{array}{c}7.05 \\
( \pm 1.73)\end{array}$ & $\begin{array}{c}8.13 \\
( \pm 2.67)\end{array}$ & $\begin{array}{c}6.88 \\
( \pm 1.47)\end{array}$ & $\begin{array}{c}4.98 \\
( \pm 1.22)\end{array}$ & $\begin{array}{c}6.07 \\
( \pm 1.29)\end{array}$ \\
\hline $\begin{array}{c}\text { Mann- } \\
\text { Kendall } \\
\tau\end{array}$ & $\begin{array}{c}0.13 \\
(p<0.001)\end{array}$ & $\begin{array}{c}0.23 \\
(p<0.001)\end{array}$ & $\begin{array}{c}0.22 \\
(p<0.001)\end{array}$ & $\begin{array}{c}0.33 \\
(p<0.001)\end{array}$ & $\begin{array}{c}0.28 \\
(p<0.001)\end{array}$ & $\begin{array}{c}0.25 \\
(p<0.001)\end{array}$ & $\begin{array}{c}0.21 \\
(p<0.001)\end{array}$ & $\begin{array}{c}0.05 \\
(p=0.07)\end{array}$ & $\begin{array}{c}0.05 \\
(p=0.07)\end{array}$ & $\begin{array}{c}-0.14 \\
(p<0.001)\end{array}$ & $\begin{array}{c}0.26 \\
(p<0.001)\end{array}$ & $\begin{array}{c}0.25 \\
(p<0.001)\end{array}$ & $\begin{array}{c}0.29 \\
(p<0.001)\end{array}$ & $\begin{array}{c}0.14 \\
(p<0.05)\end{array}$ & $\begin{array}{c}0.18 \\
(p<0.001)\end{array}$ \\
\hline
\end{tabular}

A 2.1-3: Sum of days with water level $>11 \mathrm{~m}$ at Pauh hydrological station and results of Mann-Kendall test (Mann-Kendall $\tau$ and $p$-value).

\begin{tabular}{|c|c|c|c|c|c|c|c|c|c|c|c|c|c|c|c|}
\hline \multirow{2}{*}{ Year } & \multicolumn{12}{|c|}{ Month } & \multirow{2}{*}{$\begin{array}{c}\text { Wet } \\
\text { season } \\
\text { (Oct.- } \\
\text { May) }\end{array}$} & \multirow{2}{*}{$\begin{array}{c}\text { Dry } \\
\text { season } \\
\text { (Jun.- } \\
\text { Sept.) }\end{array}$} & \multirow[b]{2}{*}{ Annual } \\
\hline & Jan. & Feb. & Mar. & Apr. & May & Jun. & Jul. & Aug. & Sept. & Oct. & Nov. & Dec. & & & \\
\hline $\begin{array}{c}\text { Average } \\
(1997- \\
2016) \\
\end{array}$ & $\begin{array}{c}1.8 \\
( \pm 1.6)\end{array}$ & $\begin{array}{c}2.5 \\
( \pm 3.1)\end{array}$ & $2( \pm 2.7)$ & $\begin{array}{c}2.2 \\
( \pm 2.4)\end{array}$ & $\begin{array}{c}1.8 \\
( \pm 1.0)\end{array}$ & 0 & 0 & 0 & 0 & 0.1 & $\begin{array}{c}1.4 \\
( \pm 0.7)\end{array}$ & $\begin{array}{c}3.6 \\
( \pm 4.3)\end{array}$ & $\begin{array}{c}15.4 \\
( \pm 1.0)\end{array}$ & 0 & $\begin{array}{c}15.4 \\
( \pm 1.0)\end{array}$ \\
\hline $\begin{array}{c}\text { Mann- } \\
\text { Kendall } \\
\tau\end{array}$ & $\begin{array}{c}0.49 \\
(p=0.01)\end{array}$ & $\begin{array}{c}0.28 \\
(p=0.15)\end{array}$ & $\begin{array}{c}0.24 \\
(p=0.21)\end{array}$ & $\begin{array}{c}0.23 \\
(p<0.24)\end{array}$ & $\begin{array}{c}0.23 \\
(p<0.23)\end{array}$ & - & - & - & - & $\begin{array}{c}0.32 \\
(p=0.12)\end{array}$ & $\begin{array}{c}0.59 \\
(p<0.01)\end{array}$ & $\begin{array}{c}0.25 \\
(p=0.17)\end{array}$ & $\begin{array}{c}0.45 \\
(p<0.01)\end{array}$ & $\begin{array}{c}0.32 \\
(p=0.12)\end{array}$ & $\begin{array}{c}0.45 \\
(p<0.01)\end{array}$ \\
\hline
\end{tabular}




\section{Determination of flood-risk areas}

In order to map areas that are prone to flooding, we followed the guidelines of the Indonesian National Agency for Disaster Management (Badan Nasional Penanggulangan Bencana / BNPB), which requires two main input datasets, namely (1) a digital elevation model (DEM) and $(2)$ the river flow network. We used the 3 arc-second $(\approx 90 \mathrm{~m})$ void-filled, open-access DEM "Hydrological Data and Maps Based on Shuttle Elevation Derivatives at Multiple Scales" (HydroSHEDS) developed by the Conservation Science Program of the World Wildlife Fund For Nature (Lehner et al. 2008). This DEM presents a combination of the Shuttle Radar Topography Mission (SRTM-3) and the void-filled digital terrain elevation data (DTED®-1) (Lehner 2013). The river network is based on the corresponding vector layer from the Indonesian Geospatial Information Agency (Badan Informasi Geospasial / BIG 2017) digitally available for Jambi Province at the scales of 1:250,000 and 1:50,000. Building on these two datasets, we determined a flooding probability by combining the slope gradient, distance from the rivers and the modified topographic index $\left(\mathrm{TI}_{\mathrm{m}}\right)$ :

$$
T I_{m}=\ln \left[\frac{a_{d}^{n}}{\tan (\beta)}\right]
$$

where ad is the local upslope contributing area per unit contour length; $\tan (\beta)$ is the local slope gradient; $\mathrm{n}$ is an exponent $(0.016 \mathrm{x} 0.46)$ and $\mathrm{x}$ is the spatial resolution of the DEM (Manfreda et al. 2011; Manfreda et al. 2014). The TIm was developed to delineate the exposure to flooding events on the basis of the basin topography (Manfreda et al. 2011). Eventually, an area was defined as flood-prone when (1) the distance to the river was $<300 \mathrm{~m},(2)$ the slope gradient $<$ $15 \%$ and (3) $T I_{m}$ exceeded a threshold $\tau$, which was set to $\tau=10.89 n+2.282$ (based on BNPB 2016), and constitutes an area that equals or exceeds $0.2 \%$ annual chance to be flooded (Holmes Jr. and Dinicola, 2010).

\section{Literature cited}

[BIG] Badan Informasi Geospasial / Indonesian Geospatial Information Agency. 2017. Peta Rupabumi. Retrieved from http://www.big.go.id/peta-rupabumi/.

[BNPB] Badan Nasional Penanggulangan Bencana / Indonesian National Agency for Disaster Management. 2016. Risiko Bencana Indonesia. Direktorat Pengurangan Risiko Bencana. Jakarta.

Holmes Jr., R.R., Dinicola, K. 2010. 100-year flood-it's all about chance. [online] URL: https://pubs.usgs.gov/gip/106/pdf/100-year-flood-handout-042610.pdf

Lehner, B., Verdin, K., and A. Jarvis. 2008. New global hydrography derived from spaceborne elevation data. Eos, Transactions, American Geophysical Union 89(10):93-94. https://doi.org/10.1029/2008EO100001 
Lehner, B. 2013. HydroSHEDS technical documentation version 1.2. Conservation Science Program World Wildlife Fund US.

Manfreda, S., Di Leo, M., and A. Sole. 2011. Detection of flood-prone areas using digital elevation models. Journal of Hydrologic Engineering 16(10):781-790. https://doi.org/10.1061/(ASCE)HE.1943-5584.0000367

Manfreda, S., Nardi, F., Samela, C., Grimaldi, S., Taramasso, A.C., Roth, G., and A. Sole. 2014. Investigation on the Use of Geomorphic Approaches for the Delineation of Flood Prone Areas, Journal of Hydrology. Journal of Hydrology 517: 863-876. https://doi.org/10.1016/j.jhydrol.2014.06.009 


\section{Precipitation}

A 2.1-4: Accumulated precipitation ( $\mathrm{mm}$ ) at Pauh meteorological station and results of Mann-Kendall test (Mann-Kendall $\tau$ and $p$-value).

\begin{tabular}{|c|c|c|c|c|c|c|c|c|c|c|c|c|c|c|c|}
\hline \multirow{2}{*}{ Year } & \multicolumn{12}{|c|}{ Month } & \multirow{2}{*}{$\begin{array}{c}\text { Wet } \\
\text { season } \\
\text { (Oct.- } \\
\text { May) }\end{array}$} & \multirow{2}{*}{$\begin{array}{c}\text { Dry } \\
\text { season } \\
\text { (Jun.- } \\
\text { Sept.) }\end{array}$} & \multirow{2}{*}{ Annual } \\
\hline & Jan. & Feb. & Mar. & Apr. & May & Jun. & Jul. & Aug. & Sept. & Oct. & Nov. & Dec. & & & \\
\hline $\begin{array}{c}\text { Average } \\
(2007- \\
2016) \\
\end{array}$ & $\begin{array}{c}290.3 \\
( \pm 115.9)\end{array}$ & $\begin{array}{c}216.7 \\
( \pm 74.1)\end{array}$ & $\begin{array}{c}268.5 \\
( \pm 149.3)\end{array}$ & $\begin{array}{c}280.3 \\
( \pm 94.6)\end{array}$ & $\begin{array}{c}244.1 \\
( \pm 83.9)\end{array}$ & $\begin{array}{c}109.6 \\
( \pm 53.0)\end{array}$ & $\begin{array}{c}170.6 \\
( \pm 94.0)\end{array}$ & $\begin{array}{c}126.6 \\
( \pm 85.2)\end{array}$ & $\begin{array}{c}141.2 \\
( \pm 112.1)\end{array}$ & $\begin{array}{c}256.1 \\
( \pm 110.3)\end{array}$ & $\begin{array}{c}352.7 \\
( \pm 119.4)\end{array}$ & $\begin{array}{c}365.0 \mathrm{~A}) \\
( \pm 162.8)\end{array}$ & $\begin{array}{c}1993.1 \\
( \pm 392.7)\end{array}$ & $\begin{array}{c}792.1 \\
( \pm 220.2)\end{array}$ & $\begin{array}{c}2785.2 \\
( \pm 547.0)\end{array}$ \\
\hline $\begin{array}{c}\text { Mann- } \\
\text { Kendall } \\
\tau\end{array}$ & $\begin{array}{c}0.16 \\
(p=0.59)\end{array}$ & $\begin{array}{c}0.38 \\
(p=0.15)\end{array}$ & $\begin{array}{c}0.33 \\
(p=0.21)\end{array}$ & $\begin{array}{c}0.20 \\
(p=0.47)\end{array}$ & $\begin{array}{c}0.60 \\
(p<0.05)\end{array}$ & $\begin{array}{c}-0.04 \\
(p=0.93)\end{array}$ & $\begin{array}{c}-0.07 \\
(p=0.86)\end{array}$ & $\begin{array}{c}-0.20 \\
(p=0.47)\end{array}$ & $\begin{array}{c}-0.24 \\
(p=0.37)\end{array}$ & $\begin{array}{c}-0.33 \\
(p=0.21)\end{array}$ & $\begin{array}{c}0.56 \\
(p<0.05)\end{array}$ & $\begin{array}{c}0.06 \\
(p=0.92)\end{array}$ & $\begin{array}{c}0.02 \\
(p=0.13)\end{array}$ & $\begin{array}{c}-0.02 \\
(p=0.33)\end{array}$ & $\begin{array}{c}0.03 \\
(p=0.65)\end{array}$ \\
\hline
\end{tabular}

No data for December 2012 available

A 2.1-5: Average precipitation intensity index ( \pm standard deviation) at Pauh meteorological station and results of Mann-Kendall test (Mann-Kendall $\tau$ and $p$-value).

\begin{tabular}{|c|c|c|c|c|c|c|c|c|c|c|c|c|c|c|c|}
\hline \multirow{2}{*}{ Year } & \multicolumn{12}{|c|}{ Month } & \multirow{2}{*}{$\begin{array}{c}\text { Wet } \\
\text { season } \\
\text { (Oct.- } \\
\text { May) }\end{array}$} & \multirow{2}{*}{$\begin{array}{c}\text { Dry } \\
\text { season } \\
\text { (Jun.- } \\
\text { Sept.) }\end{array}$} & \multirow[b]{2}{*}{ Annual } \\
\hline & Jan. & Feb. & Mar. & Apr. & May & Jun. & Jul. & Aug. & Sept. & Oct. & Nov. & Dec. & & & \\
\hline $\begin{array}{l}2007- \\
2016\end{array}$ & $\begin{array}{c}15.9 \\
( \pm 13.3)\end{array}$ & $\begin{array}{c}17.6 \\
( \pm 13.5)\end{array}$ & $\begin{array}{c}17.2 \\
( \pm 16.1)\end{array}$ & $\begin{array}{c}22.0 \\
( \pm 19.0)\end{array}$ & $\begin{array}{c}21.6 \\
( \pm 21.2)\end{array}$ & $\begin{array}{c}13.7 \\
( \pm 13.5)\end{array}$ & $\begin{array}{c}18.5 \\
( \pm 22.5)\end{array}$ & $\begin{array}{c}15.4 \\
( \pm 16.5)\end{array}$ & $\begin{array}{c}17.3 \\
( \pm 16.9)\end{array}$ & $\begin{array}{c}17.1 \\
( \pm 14.0)\end{array}$ & $\begin{array}{c}24.4 \\
( \pm 22.4)\end{array}$ & $\begin{array}{c}23.3 \\
( \pm 23.1)\end{array}$ & $\begin{array}{c}20.2 \\
( \pm 18.8)\end{array}$ & $\begin{array}{c}16.0 \\
( \pm 17.6)\end{array}$ & $\begin{array}{c}19.0 \\
( \pm 18.6)\end{array}$ \\
\hline $\begin{array}{c}\text { Mann- } \\
\text { Kendall } \\
\tau\end{array}$ & $\begin{array}{c}-0.14 \\
(p=0.13)\end{array}$ & $\begin{array}{c}0.11 \\
(p=0.26)\end{array}$ & $\begin{array}{c}0.16 \\
(p=0.04)\end{array}$ & $\begin{array}{c}-0.09 \\
(p=0.29)\end{array}$ & $\begin{array}{c}0.07 \\
(p=0.40)\end{array}$ & $\begin{array}{c}-0.08 \\
(p=0.40)\end{array}$ & $\begin{array}{c}0.14 \\
(p=0.10)\end{array}$ & $\begin{array}{c}-0.09 \\
(p=0.32)\end{array}$ & $\begin{array}{c}-0.05 \\
(p=0.66)\end{array}$ & $\begin{array}{c}-0.14 \\
(p=0.13)\end{array}$ & $\begin{array}{c}0.02 \\
(p=0.81)\end{array}$ & $\begin{array}{c}0.06 \\
(p=0.4 \\
7) \\
\end{array}$ & $\begin{array}{c}0.02 \\
(p=0.59)\end{array}$ & $\begin{array}{c}-0.02 \\
(p=0.71)\end{array}$ & $\begin{array}{c}0.01 \\
(p=0.81)\end{array}$ \\
\hline
\end{tabular}


A 2.1-6: Mean precipitation ( $\mathrm{mm}$ ) at Jambi airport meteorological station and results of Mann-Kendall test (Mann-Kendall $\tau$ and p-value) during the period 1978-2016.

\begin{tabular}{|c|c|c|c|c|c|c|c|c|c|c|c|c|c|c|c|}
\hline \multirow{2}{*}{ Year } & \multicolumn{12}{|c|}{ Month } & \multirow{2}{*}{$\begin{array}{c}\text { Wet } \\
\text { season } \\
\text { (Oct.- } \\
\text { May) }\end{array}$} & \multirow{2}{*}{$\begin{array}{c}\text { Dry } \\
\text { season } \\
\text { (Jun.- } \\
\text { Sept.) } \\
\end{array}$} & \multirow{2}{*}{ Annual } \\
\hline & Jan. & Feb. & Mar. & Apr. & May & Jun. & Jul. & Aug. & Sept. & Oct. & Nov. & Dec. & & & \\
\hline $\begin{array}{l}1978- \\
2016\end{array}$ & $\begin{array}{c}199.3 \\
( \pm 85.7)\end{array}$ & $\begin{array}{c}180.2 \\
( \pm 79.9)\end{array}$ & $\begin{array}{c}233.9 \\
( \pm 82.7)\end{array}$ & $\begin{array}{c}256.0 \\
( \pm 90.0)\end{array}$ & $\begin{array}{c}170.5 \\
( \pm 64.8)\end{array}$ & $\begin{array}{c}112.4 \\
( \pm 64.6)\end{array}$ & $\begin{array}{c}112.5 \\
( \pm 81.4)\end{array}$ & $\begin{array}{c}124.6 \\
( \pm 92.9)\end{array}$ & $\begin{array}{c}129.6 \\
( \pm 86.1)\end{array}$ & $\begin{array}{c}223.0 \\
( \pm 105.8)\end{array}$ & $\begin{array}{c}241.1 \\
( \pm 98.9)\end{array}$ & $\begin{array}{c}248.2 \\
( \pm 86.6)\end{array}$ & $\begin{array}{l}1798.2 \\
( \pm 91.6)\end{array}$ & $\begin{array}{c}491.7 \\
( \pm 81.4)\end{array}$ & $\begin{array}{l}2289.9 \\
( \pm 99.9)\end{array}$ \\
\hline $\begin{array}{c}\text { Mann- } \\
\text { Kendall } \\
\tau\end{array}$ & $\begin{array}{c}-0.28 \\
(p=0.01)\end{array}$ & $\begin{array}{c}-0.08 \\
(p=0.51)\end{array}$ & $\begin{array}{c}-0.02 \\
(p=0.85)\end{array}$ & $\begin{array}{c}-0.22 \\
(p=0.05)\end{array}$ & $\begin{array}{c}-0.12 \\
(p=0.31)\end{array}$ & $\begin{array}{c}-0.08 \\
(p=0.51)\end{array}$ & $\begin{array}{c}0.16 \\
(p=0.16)\end{array}$ & $\begin{array}{c}0.10 \\
(p=0.38)\end{array}$ & $\begin{array}{c}-0.16 \\
(p=0.16)\end{array}$ & $\begin{array}{c}-0.13 \\
(p=0.24)\end{array}$ & $\begin{array}{c}-0.06 \\
(p=0.63)\end{array}$ & $\begin{array}{c}0.02 \\
(p=0.85)\end{array}$ & $\begin{array}{c}0.09 \\
(p=0.02)\end{array}$ & $\begin{array}{c}0.03 \\
(p=0.54)\end{array}$ & $\begin{array}{c}-0.05 \\
(p=0.10)\end{array}$ \\
\hline
\end{tabular}

A 2.1-7: Average precipitation intensity index ( \pm standard deviation) at Jambi Airport meteorological station and results of Mann-Kendall test (Mann-Kendall $\tau$ and p-value).

\begin{tabular}{|c|c|c|c|c|c|c|c|c|c|c|c|c|c|c|c|}
\hline Year & \multicolumn{12}{|c|}{ Month } & $\begin{array}{c}\text { Wet } \\
\text { season } \\
\text { (Oct.- } \\
\text { May) }\end{array}$ & $\begin{array}{c}\text { Dry } \\
\text { season } \\
\text { (Jun.- } \\
\text { Sept.) } \\
\end{array}$ & Annual \\
\hline $\begin{array}{l}1991- \\
2016\end{array}$ & $\begin{array}{c}11.3 \\
( \pm 11.9)\end{array}$ & $\begin{array}{c}13.1 \\
( \pm 13.4)\end{array}$ & $\begin{array}{c}16.1 \\
( \pm 16.6)\end{array}$ & $\begin{array}{c}14.2 \\
( \pm 14.2)\end{array}$ & $\begin{array}{c}12.8 \\
( \pm 12.8)\end{array}$ & $\begin{array}{c}11.9 \\
( \pm 14.6)\end{array}$ & $\begin{array}{c}15.3 \\
( \pm 18.2)\end{array}$ & $\begin{array}{c}13.7 \\
( \pm 15.5)\end{array}$ & $\begin{array}{c}11.1 \\
( \pm 12.0)\end{array}$ & $\begin{array}{c}14.7 \\
( \pm 12.4)\end{array}$ & $\begin{array}{c}14.4 \\
( \pm 13.0)\end{array}$ & $\begin{array}{c}15.7 \\
( \pm 15.0)\end{array}$ & $\begin{array}{c}14.0 \\
( \pm 13.8)\end{array}$ & $\begin{array}{c}13.0 \\
( \pm 15.2)\end{array}$ & $\begin{array}{c}13.8 \\
( \pm 14.2)\end{array}$ \\
\hline
\end{tabular}




\section{Accuracy statistics of land use/cover classes}

A 2.1-8: Accuracy statistics and area proportion of each land use/cover class in the Tembesi watershed for the year 2013 (recalculated from Melati 2017).

\begin{tabular}{|c|c|c|c|c|c|}
\hline \multirow{2}{*}{ Land use/ cover class } & \multicolumn{3}{|c|}{ Accuracy } & \multicolumn{2}{|c|}{ Area proportion (\%) } \\
\hline & User's & Producer's & Overall & Map & Estimated \\
\hline Agriculture & $72.4 \pm 16.6$ & $95.6 \pm 5.4$ & \multirow{7}{*}{$85.8 \pm 4.4$} & 16.3 & $12.4 \pm 2.8$ \\
\hline Bush/bareland & $79.4 \pm 10.1$ & $60.3 \pm 17.4$ & & 7.1 & $9.4 \pm 2.8$ \\
\hline Forest & $93.9 \pm 6.8$ & $95.4 \pm 3.2$ & & 38.1 & $37.5 \pm 2.9$ \\
\hline Oil palm & $83.3 \pm 10$ & $68.5 \pm 13.8$ & & 10.8 & $13.1 \pm 2.8$ \\
\hline Rubber & $86.4 \pm 7.5$ & $90.9 \pm 6.7$ & & 25.6 & $24.4 \pm 2.6$ \\
\hline Settlement & $81.3 \pm 19.8$ & $35.2 \pm 22.3$ & & 1.3 & $2.9 \pm 1.8$ \\
\hline Water body & $50 \pm 43.8$ & $100 \pm 0$ & & 0.8 & \pm 0.3 \\
\hline
\end{tabular}




\subsection{Riparian wetland properties counter the effect of land-use change on soil carbon stocks after rainforest conversion to plantations}

Nina Hennings ${ }^{*}$, Joscha N. Becker 2, Thomas Guillaume ${ }^{3,4,5}$, Muhammad Damris ${ }^{6}$, Michaela A. Dippold7, Yakov Kuzyakov ${ }^{1,8}$

published in: Catena, Volume 196, 2021, 104941, https://doi.org/10.1016/j.catena.2020.104941

${ }^{1}$ Soil Science of Temperate Ecosystems, University of Göttingen, Germany

${ }^{2}$ Institute of Soil Science, CEN Center for Earth System Research and Sustainability, University of Hamburg, Germany

${ }^{3}$ Agroscope, Field-Crop Systems and Plant Nutrition, Research Division Plant Production Systems, Route de Duillier 50, P.O. Box 1012, CH-1260 Nyon, Switzerland

${ }^{4}$ Laboratory of Ecological Systems, Swiss Federal Institute of Technology in Lausanne, Switzerland

${ }^{5}$ Swiss Federal Institute for Forest, Snow and Landscape Research WSL, Site Lausanne, 1015 Lausanne, Switzerland

${ }^{6}$ Faculty of Science and Technology, University of Jambi, Indonesia

Biogeochemistry of Agroecosystems, University of Göttingen, Germany

${ }^{8}$ Department of Agricultural Soil Science, University of Göttingen, Germany

*Corresponding author: Nina Hennings, Soil Science of Temperate Ecosystems, University of Göttingen, Büsgenweg 2, 37077 Göttingen, Germany. E-mail: nina.hennings@forst.unigoettingen.de, Telephone: +49 (0) 5513912294 


\subsubsection{ABSTRACT}

Progressive conversion of tropical rainforests to agricultural monocultures in South East Asia increasingly affects landscape types such as riparian areas. The impacts of conversions on soil organic matter (SOM) vary with changing landforms. However, this was often not accounted for in previous studies where SOM in soils in riparian areas was combined with SOM from well-drained adjacent slopes. Because riparian areas have a high carbon (C) storage potential, our objectives were i) to assess their $\mathrm{C}$ stocks after conversion to rubber and oil palm plantations in Sumatra (Indonesia) and ii) to compare the impacts of land use conversion on $\mathrm{C}$ stocks between riparian and well-drained areas. Average soil C stock losses from the top $30 \mathrm{~cm}$ were about $14 \%$ and $4 \%$ following conversion of riparian forest to rubber and oil palm plantations, respectively, indicating a high resistance of $\mathrm{C}$ to mineralization. C losses from well-drained areas were twice as high as from riparian areas after the respective conversion. $\delta^{13} \mathrm{C}$ values from riparian areas showed clear heterogeneity down soil profiles that was explained i) by alternating oxic and anoxic conditions, leading to reduced SOM and litter decomposition in riparian areas and ii) by mineral sediments and organic matter deposition and accumulation by erosion from adjacent slopes covered by plantations. We conclude that riparian areas are more resilient in terms of soil C storage towards land-use change than well-drained areas because of sediment deposition and reduced oxygen availability. On this basis, we developed a conceptual model of the effects of land-use change and various ecotone characteristics on SOM mineralization in the topand subsoil of riparian areas.

Keywords: carbon cycle; isotopes; Indonesia; land-use change; riparian; erosion and deposition, stable isotopes 


\subsubsection{INTRODUCTION}

The growing demand for cash crop products, such as palm oil and rubber, causes the conversion of tropical rainforests into agricultural land. This land-use change towards intensively managed plantations has major impacts on the global carbon $(C)$ cycle, since it reduces soil organic carbon (SOC) stocks and increases carbon dioxide emissions (Don et al., 2011; Harris et al., 2012). The tropics play a crucial role in global C reservoirs, as they store one third of the global soil C (Scharlemann et al., 2014). Due to the described land-use change the total anthropogenic carbon dioxide emissions increased by $48 \%$ (Ciais et al., 2013).

In 2012, Indonesia had the highest deforestation rate in the world (0.84 Mha) (Margono et al., 2014). Deforestation is particularly severe on the island of Sumatra, where vast expanses of lowland rainforest have been converted into oil palm and rubber plantations (Austin et al., 2019; Margono et al., 2014). Various studies showed that the forest conversion into agricultural land is accompanied with C losses from mineral soil in this region (Borchard et al., 2019; de Blécourt et al., 2013; Guillaume et al., 2015). In mineral soils in well-drained areas, land-use changes induce SOC losses mainly by decreased C input, accelerated decomposition, or increased erosion (Guillaume et al., 2015). The conversion into plantations reduces above- and belowground biomass up to five fold (Guillaume et al., 2018; Kotowska et al., 2015) leading to a reduced C input (Powers, 2004). In combination with mineral fertilization, which reduces the nutrient limitation of soil microbial communities, this accelerates biogeochemical cycles and triggers the decomposition of soil organic matter (SOM) (Becker et al., 2015; Becker and Kuzyakov, 2018). Additionally, reduced vegetation cover in plantations strongly increases soil erosion, which in turn leads to a loss of the C-rich topsoil (Don et al., 2011; Guillaume et al., 2015; Labrière et al., 2015). Forest soils in tropical wetlands have a large C-stock potential (Wantzen et al. 2012) and particularly large $\mathrm{C}$ losses are expected from conversion into agricultural land. However, most research with specific focus on riparian areas has been conducted in temperate regions (Guyette et al., 2002; Zehetner et al., 2009). The impact of land-use change in non-peat riparian areas on $\mathrm{C}$ losses has hardly been investigated; yet in the tropics (Wantzen et al., 2012). The distinction between the terms 'riparian area' and 'wetland' mainly depends on three main differences: first, riparian areas are commonly transitional zones between terrestrial ecosystems and water bodies. These areas are temporarily inundated or water- 
logged (Wantzen et al., 2008) with a high water table (McCormick, 1978) and can experience seasonal wet and dry cycles, i.e., temporal changes between oxic and anoxic conditions (Décamps et al., 2004). The term 'wetland', however, describes soils that are often watersaturated but do not need to be adjacent to a river. Second, related to the divergent locations, the terms describe different energy and temporal dynamics of the affecting water body. Riparian areas often reflect higher water flow dynamics where sediments are transported and material accumulation and erosion occur. On the contrary, wetlands are associated with a water table that is close to or above the surface and are characterized by only a scarce flow of water (Brown et al., 1978). Third, as mineral and organic soils both occur within wetlands, the level of organic content is not the only indicator to identify riparian areas as a certain type of wetland. The riparian SOM balance is further influenced by two specific factors: the redistribution of fluvial sediment (Rieger et al., 2014) and oxygen deficiency in water-saturated soil. The effects of these processes on riparian $\mathrm{C}$ balances and stabilization can offset erosion and SOM mineralization. Deposits that enter (and partly leave) the ecotone contain high amounts of allochthonous organic material from terrestrial sources and dissolved organic matter from aquatic sources (Moore et al., 2013). Flooding duration and frequency also play crucial roles for long term $\mathrm{C}$ accumulation (Bendix and Hupp, 2000; Graf-Rosenfellner et al., 2016).

Depth profiles of natural ${ }^{13} \mathrm{C}$ abundance $\left(\delta^{13} \mathrm{C}\right)$ serve as helpful tools to evaluate the decomposition state of SOM (Alewell et al., 2011; Guillaume et al., 2015; Krüger et al., 2014). The $\delta^{13} \mathrm{C}$ value describes the ratio of ${ }^{13} \mathrm{C}:{ }^{12} \mathrm{C}$ abundance relatively to the international PDB limestone standard (Craig, 1953). SOM and litter decomposition lead to an ${ }^{13} \mathrm{C}$ enrichment of SOM and, thus, they induce a shift to less negative $\delta^{13} \mathrm{C}$ values. In well-drained mineral soils, an increase of $\delta^{13} \mathrm{C}$ values was observed with soil depth and soil age (Andreeva et al., 2013; de; Zang et al., 2018). Apparently here, aerobic decomposition processes dominate and lead to ${ }^{13} \mathrm{C}$ enrichment. In contrast, soils in riparian areas experience wet and-dry cycles, and thus alternating oxic and anoxic conditions, which change the ${ }^{13} \mathrm{C}$ fractionation with depth. The delayed decomposition under anoxic conditions, might slow down the ${ }^{13} \mathrm{C}$ fractionation. Here, $\delta^{13} \mathrm{C}$ values show a more stable and uniform pattern. If shifts to lighter $\delta^{13} \mathrm{C}$ values are detected, this will hint to an enrichment of recalcitrant organic substances during anaerobic decomposition which are depleted in ${ }^{13} \mathrm{C}$ (Alewell et al., 2011; Drollinger et al., 2019). 
For the assessment of erosion, it is required that the $\delta^{13} \mathrm{C}$ values in the plantation subsoil are similar to those in the forest subsoil prior conversion. Assuming that subsoil $\delta^{13} \mathrm{C}$ values are unaffected by land-use change or surface matter inputs, a shift of topsoil $\delta^{13} \mathrm{C}$ towards subsoil $\delta^{13} \mathrm{C}$ values may be interpreted as erosion dynamics. The respective layer experienced a vertical shift towards the soil surface after an erosional loss of the upper layer (Guillaume et al., 2015). In addition, physical mixing and deposition of fresh material with differing isotopic composition, can influence the profiles' ${ }^{13} \mathrm{C}$ signature, particularly in dynamic landscapes like riparian areas (de Junet et al., 2005; Kelleway et al., 2017). Therefore, riparian properties may lead to unique $\mathrm{C}$ storage mechanisms, which are expressed as specific dynamics in the $\delta^{13} \mathrm{C}$ value. It is essential to understand the combined effects of land-use change and riparian water dynamics on soil $\mathrm{C}$ balance to predict probable climate change responses and the mitigation potential of riparian areas. This is of special importance because riparian areas have a high $\mathrm{C}$ storage potential (Hazlett et al., 2005) which makes them a valuable asset for regional and global carbon management (Rieger et al., 2014).

Therefore, the objectives of this study were i) to quantify SOC losses in riparian areas after land-use change from forest to oil palm and rubber plantations, and ii) to determine whether the impacts of this land-use change are comparable for riparian and well-drained areas. We further aimed iii) to develop a conceptional understanding of $\mathrm{C}$ sequestration and storage in riparian areas by using the $\delta^{13} \mathrm{C}$ values to disentangle SOM decomposition from erosion and deposition. We hypothesize that (1) the conversion of riparian forest to plantations has a more negative impact on soil C stocks than for well-drained mineral soils because anoxic conditions slow down decomposition and thus lead to higher $\mathrm{C}$ storage. We hypothesize that (2) not SOC mineralization but SOM transport and deposition are the factors that predominantly influence SOC stocks. 


\subsubsection{MATERIALS AND METHODS}

\subsubsection{Study Site}

The study was carried out in the Province of Jambi in Sumatra, Indonesia. The region has a tropical humid climate with an average annual temperature of $27.6^{\circ} \mathrm{C}$. Average annual rainfall is $2235 \mathrm{~mm}$. The rainy season has two peak periods (March and December) and an average monthly rainfall of $261 \mathrm{~mm}$, followed by a drier period between April and September with a monthly rainfall of $161 \mathrm{~mm}$ (Drescher et al., 2016). The natural vegetation is a mixed dipterocarp lowland rainforest (Laumonier, 1997). Nowadays, however, Jambi Province is a region dominated by large rubber (Hevea brasiliensis) and oil palm (Elaeis guineensis) monocultures. Plantations managed by smallholder farmers were selected, which varied between 8-18 years (rubber) and 10-16 years (oil palm) in stand age (Drescher et al., 2016). Study plots have been established in two landscape types: well-drained areas and riparian areas. In each land-use and landscape type four 50x50 m study plots have been established. Additionally, four well-drained sites and four riparian sites from the Harapan Rainforest, an ecosystem restoration area, were used as references, resulting in a total number of 24 plots (Table 2.2-1). SOC data from these plots allowed for SOC stock change calculations after land-use change and an additional comparison between landscape types. Well-drained areas and SOC data are described in detail in Guillaume et al. (2015).

\subsubsection{Sampling and analysis}

We used an identical sampling design for riparian areas as well as for well-drained areas, sampling from four spatially independent plot replicates. At each replicate plot, a $1 \mathrm{~m}$ deep soil profile was established. The soils were classified according to the IUSS Working Group WRB, 2014 by the FAO as Acrisols with a sandy loam texture in the well-drained areas (Guillaume et al., 2015) and Gleysols, Stagnosols and stagnic Acrisols with a loamic and clayic texture in the riparian areas (Table 2.2-1). Soil samples in the riparian areas were collected in depth intervals $(0-5,5-10,10-20,20-30.30-50,50-70,70-90,90-100 \mathrm{~cm})$. In case of horizon boundaries within the selected intervals, sampling was adapted to avoid a mixture of horizons within the sample. Sampling was evenly distributed to cover the whole depth interval. Samples for bulk density were collected in five replicates from each depth interval: $100 \mathrm{~cm}^{3}$ soil rings were inserted horizontally, weighed and dried at $105{ }^{\circ} \mathrm{C}$ until constant weight. Guillaume et. al. (2015) sampled well-drained soil on horizon basis. These data 
were merged with our data set by recalculating horizon data, based on their relative contribution to each depth interval.

Soil samples for organic $\mathrm{C}$ and total $\mathrm{N}$ as well as $\delta^{13} \mathrm{C}$ (\% VPDB) analyses were dried for two weeks at $40{ }^{\circ} \mathrm{C}$, sieved to $2 \mathrm{~mm}$ and ground before analyses. Due to the absence of inorganic $\mathrm{C}$ and $\mathrm{N}$, total $\mathrm{C}$ and $\mathrm{N}$ correspond to organic $\mathrm{C}$ and $\mathrm{N}$. Measurements were performed at the Center for Stable Isotope Research and Analysis (KOSI) of the University of Göttingen using an Elemental Analyser (NA1110, CE-Instruments, Rodano, Milano, Italy) coupled via a ConFlow III to an isotope ratio mass spectrometer (Delta Plus, Finnigan MAT, Bremen, Germany). Before soil texture analysis iron oxides were removed by using sodium dithionite. 
Table 2.2-1: Sampling site characteristics

\begin{tabular}{|c|c|c|c|c|c|c|c|c|c|}
\hline $\begin{array}{l}\text { Landscape } \\
\text { type }\end{array}$ & $\begin{array}{l}\text { Land use } \\
\text { type }\end{array}$ & $\begin{array}{l}\text { Local } \\
\text { name }\end{array}$ & $\begin{array}{l}\text { Geographical } \\
\text { coordinates }\end{array}$ & $\begin{array}{c}\text { Soil } \\
\text { group }\end{array}$ & Texture & $\begin{array}{l}\text { Stand } \\
\text { age }\end{array}$ & $\begin{array}{l}\text { sampling } \\
\text { depths } \\
\text { (cm) } \\
\end{array}$ & $\begin{array}{l}\text { Sampling } \\
\text { year }\end{array}$ & $\begin{array}{l}\text { Field } \\
\text { replicates }\end{array}$ \\
\hline riparian & $\begin{array}{c}\text { Dipterocarp } \\
\text { lowland } \\
\text { rainforest }\end{array}$ & $\begin{array}{l}\text { Hutan } \\
\text { primer }\end{array}$ & $\begin{array}{c}\text { S } 02^{\circ} 10^{\prime} 24.4^{\prime \prime} \\
\text { E } 103^{\circ} 21^{\prime} 56.1^{\prime \prime} \\
\text { S } 02^{\circ} 10^{\prime} 51.9^{\prime \prime} \\
\text { E } 103^{\circ} 20^{\prime} 07.8^{\prime \prime} \\
\text { S } 02^{\circ} 111^{\prime} 23.9^{\prime \prime} \\
\text { E } 103^{\circ} 20^{\prime} 39.5^{\prime \prime}\end{array}$ & $\begin{array}{l}\text { Gleysol } \\
\text { Acrisol } \\
\text { Stagnosol }\end{array}$ & $\begin{array}{l}\text { Loamic } \\
\text { Siltic } \\
\text { Clayic }\end{array}$ & $\begin{array}{l}\text { Degraded } \\
\text { primary } \\
\text { (Margono } \\
\text { et al., } \\
2014 \text { ) }\end{array}$ & $\begin{array}{l}0-5 ; 5-10 \\
10-20 ; 20- \\
30 ; 30-50 ; \\
50-70 ; 70- \\
90 ; 90-100\end{array}$ & 2016 & 3 \\
\hline riparian & $\begin{array}{c}\text { Rubber } \\
\text { Monoculture }\end{array}$ & $\begin{array}{l}\text { Kebun } \\
\text { Karet }\end{array}$ & $\begin{array}{c}\text { S } 01^{\circ} 44^{\prime} 18.9^{\prime \prime} \\
\text { E } 103^{\circ} 18^{\prime} 50.0^{\prime \prime} \\
\text { S } 01^{\circ} 53^{\prime} 14.3^{\prime \prime} \\
\text { E } 103^{\circ} 17^{\prime} 29.2^{\prime \prime} \\
\text { S } 01^{\circ} 51^{\prime} 42.3^{\prime \prime} \\
\text { E } 103^{\circ} 18^{\prime} 20.4^{\prime \prime} \\
\text { S } 01^{\circ} 42^{\prime} 39.6^{\prime \prime} \\
\text { E } 103^{\circ} 17^{\prime} 23.3^{\prime \prime}\end{array}$ & $\begin{array}{l}\text { Gleysol } \\
\text { Acrisol } \\
\text { Acrisol } \\
\text { Acrisol }\end{array}$ & $\begin{array}{c}\text { Loamic/Clayic } \\
\text { Clayic } \\
\text { Loamic } \\
\text { Loamic }\end{array}$ & $\begin{array}{l}8-18 \\
\text { years }\end{array}$ & $\begin{array}{l}0-5 ; 5-10 \\
10-20 ; 20- \\
30 ; 30-50 ; \\
50-70 ; 70- \\
90 ; 90-100\end{array}$ & 2016 & 4 \\
\hline riparian & $\begin{array}{l}\text { Oil Palm } \\
\text { Monoculture }\end{array}$ & $\begin{array}{l}\text { Kebun } \\
\text { Sawit }\end{array}$ & $\begin{array}{c}\text { S } 01^{\circ} 54^{\prime} 07.7^{\prime \prime} \\
\text { E } 103^{\circ} 22^{\prime} 53.3^{\prime \prime} \\
\text { S } 01^{\circ} 52^{\prime} 40.5^{\prime \prime} \\
\text { E } 103^{\circ} 21^{\prime} 23.0^{\prime \prime} \\
\text { S } 01^{\circ} 51^{\prime} 40.2^{\prime \prime} \\
\text { E } 103^{\circ} 18^{\prime} 20.2^{\prime \prime} \\
\text { S } 01^{\circ} 42^{\prime} 39.5^{\prime \prime} \\
\text { E } 103^{\circ} 17^{\prime} 31.1^{\prime \prime}\end{array}$ & $\begin{array}{c}\text { Stagnosol } \\
\text { Stagnosol } \\
\text { Stagnosol } \\
\text { Acrisol }\end{array}$ & $\begin{array}{l}\text { Clayic } \\
\text { Clayic } \\
\text { Loamic } \\
\text { Clayic }\end{array}$ & $\begin{array}{l}10-16 \\
\text { years }\end{array}$ & $\begin{array}{l}0-5 ; 5-10 \\
10-20 ; 20- \\
30 ; 30-50 \\
50-70 ; 70- \\
90 ; 90-100\end{array}$ & 2016 & 4 \\
\hline well-drained & $\begin{array}{c}\text { Dipterocarp } \\
\text { lowland } \\
\text { rainforest }\end{array}$ & $\begin{array}{l}\text { Hutan } \\
\text { primer }\end{array}$ & $\begin{array}{c}\text { S } 01^{\circ} 54^{\prime} 35.6^{\prime \prime} \\
\text { E } 103^{\circ} 15^{\prime} 58.3^{\prime \prime} \\
\text { S } 01^{\circ} 53^{\prime} 00.7^{\prime \prime} \\
\text { E } 103^{\circ} 16^{\prime} 03.6^{\prime \prime} \\
\text { S } 01^{\circ} 51^{\prime} 28.4^{\prime \prime} \\
\text { E } 103^{\circ} 18^{\prime} 27.4^{\prime \prime} \\
\text { S } 01^{\circ} 47^{\prime} 12.7^{\prime \prime} \\
\text { E } 103^{\circ} 16^{\prime} 14.0^{\prime \prime}\end{array}$ & $\begin{array}{l}\text { Acrisol } \\
\text { Acrisol } \\
\text { Acrisol } \\
\text { Acrisol }\end{array}$ & $\begin{array}{l}\text { Sandy loam } \\
\text { Sandy loam } \\
\text { Sandy loam } \\
\text { Sandy loam }\end{array}$ & $\begin{array}{l}\text { Degraded } \\
\text { primary } \\
\text { (Margono } \\
\text { et al., } \\
\text { 2014) }\end{array}$ & $\begin{array}{l}\text { By horizon } \\
\text { and } \\
\text { recalculated } \\
\text { see } \\
\text { Guillaume } \\
\text { et al. } \\
\text { (2015) }\end{array}$ & 2012 & 4 \\
\hline
\end{tabular}




\section{Calculations and Statistics}

The SOC stocks were calculated by multiplying the $\mathrm{C}$ content with the respective bulk density of each depth. Bulk Density data between 50-100 cm soil depth were only for riparian areas available to calculate SOC stock. All statistics and graphing were performed in R v3.5.1 (R Core Team, 2018) using base, agricolae (de Mendiburu, 2017), car (Fox and Weisberg, 2011), ggplot2 (Wickham, 2016), tidyverse (Wickham, 2017), ggpubr (Kassambara, 2018) and rstatix (Kassambara, 2020) packages. We excluded one riparian forest profile because of very high topsoil C content (26\%) which already hinted at peat formation and, therefore, did not represent the targeted mineral soil conditions. The effects of land-use change on $\mathrm{C}$ and $\mathrm{N}$ contents, $\mathrm{C} / \mathrm{N}$ ratio and $\delta^{13} \mathrm{C}$ signature within the riparian area were assessed by a Two-Way split-plot ANOVA $(p$-level < 0.05) with depth as interacting factor within individual plots. Pvalues from multiple comparisons were adjusted by Bonferroni correction. The combined effects of the landscape and land-use type on soil C stocks were compared for three depth ranges $(0-10,0-30$ and 0-50 cm), using a Two-Way ANOVA, at $p$-level $<0.05$ with factor interaction. Tukey HSD post-hoc analysis was used for group comparisons. Variance between groups were homogeneous (Levene's test $(p$-level > 0.05). ANOVA model residuals were normally distributed (Shapiro-Wilk test, $p>0.05$ ). Occasional deviations from the normality assumption of groups were small and considered acceptable, given the robustness of homoscedastic ANOVA. 


\subsubsection{RESULTS}

\subsubsection{Effect of land use on riparian areas}

Carbon content $\left(\mathrm{g} \mathrm{kg}^{-1}\right)$ in the topsoil $(0-10 \mathrm{~cm})$ of riparian areas were $34 \%$ and $11 \%$ higher in the forest than in rubber and oil palm plantations, respectively (Figure 2.2-1). Carbon content declined from topsoil to subsoil across all land-use types $(p<0.05)$. In the forest, the high $\mathrm{C}$ content of $28 \mathrm{~g} \mathrm{~kg}^{-1} \mathrm{C}$ and $29 \mathrm{~g} \mathrm{~kg}^{-1} \mathrm{C}$ at 80 and $95 \mathrm{~cm}$ soil depth resulted from a buried C-rich layer at one of the sites (Figure 2.2-1).
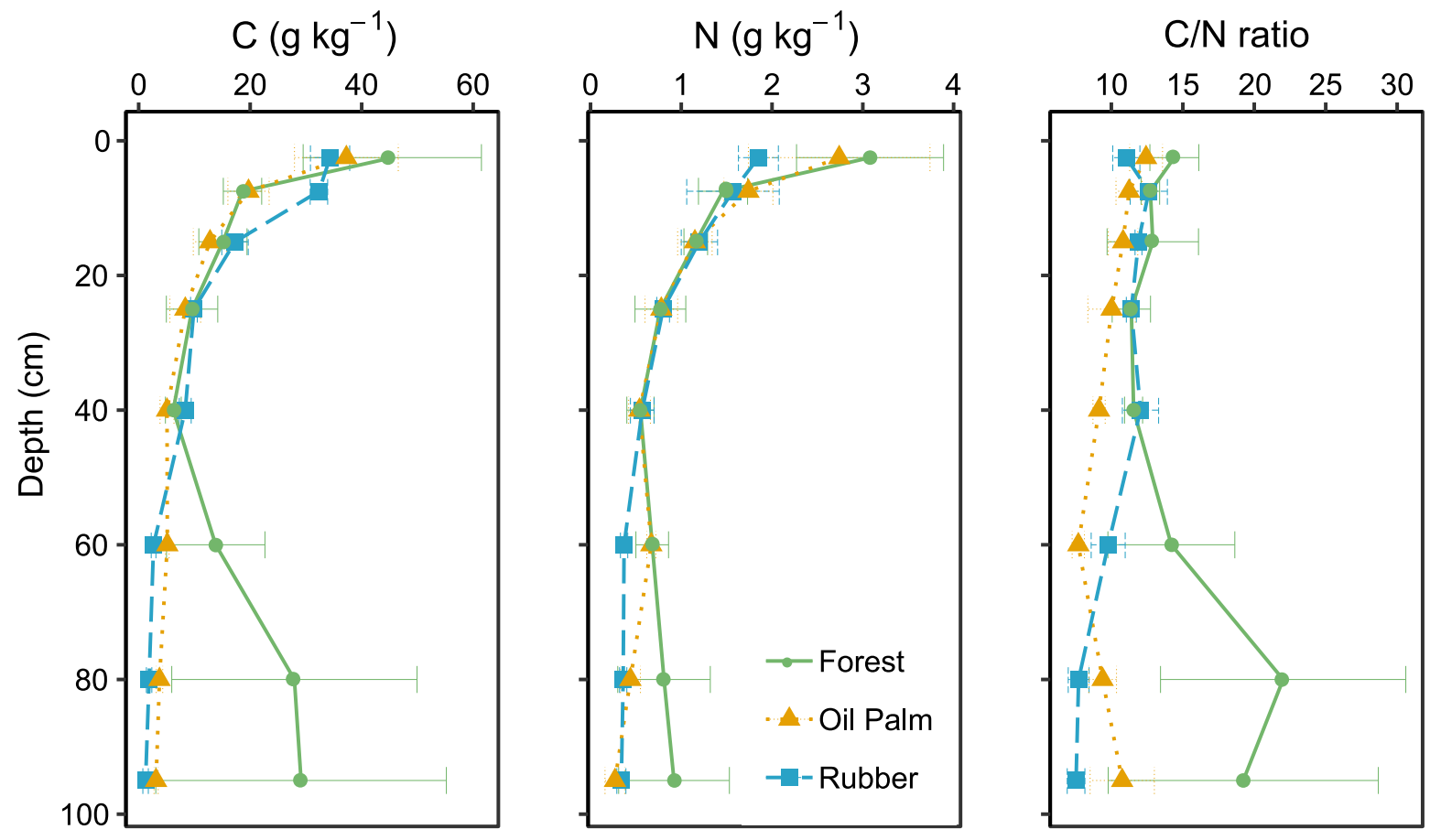

Figure 2.2-1: Depth profiles of C content $\left(\mathrm{g} \mathrm{kg}^{-1}\right), N$ content $\left(\mathrm{g} \mathrm{kg}^{-1}\right)$ and C/N ratio in forest (green), rubber (blue) and oil palm (yellow) plantations. Values represent means (in forest $n=3$, in plantations $n=4$ ). Error Bars indicate the standard error of the mean (SEM).

Differences in Nitrogen $(\mathrm{N})$ content between the land-use types were not significant in any depth. Across all land-use types, N contents decreased with depth (Two-Way split-plot ANOVA, $p<0.05)$. Under forests, $\mathrm{N}$ content re-increased within 60 to $100 \mathrm{~cm}$ depth, associated with an increase in C content over the same depth interval (Figure 2.2-1), reflecting paleosol formation (Figure 2.2-2, right). In riparian areas, the topsoil $\mathrm{C} / \mathrm{N}$ ratio was highest in the forests and lowest in rubber plantations, varying between 14.0 (forest) and $11.7 \mathrm{~g} \mathrm{~N} \mathrm{~kg}^{-1}$ (rubber). In oil palm plantations, $\mathrm{C} / \mathrm{N}$ ratios slightly decreased with increasing depth (down to a minimum of 7.6). In forest subsoil, an increase up to 22.0 at $80 \mathrm{~cm}$ soil depth was found. $\mathrm{C} / \mathrm{N}$ ratios differed $(p<0.05)$ between all three land-use types. 

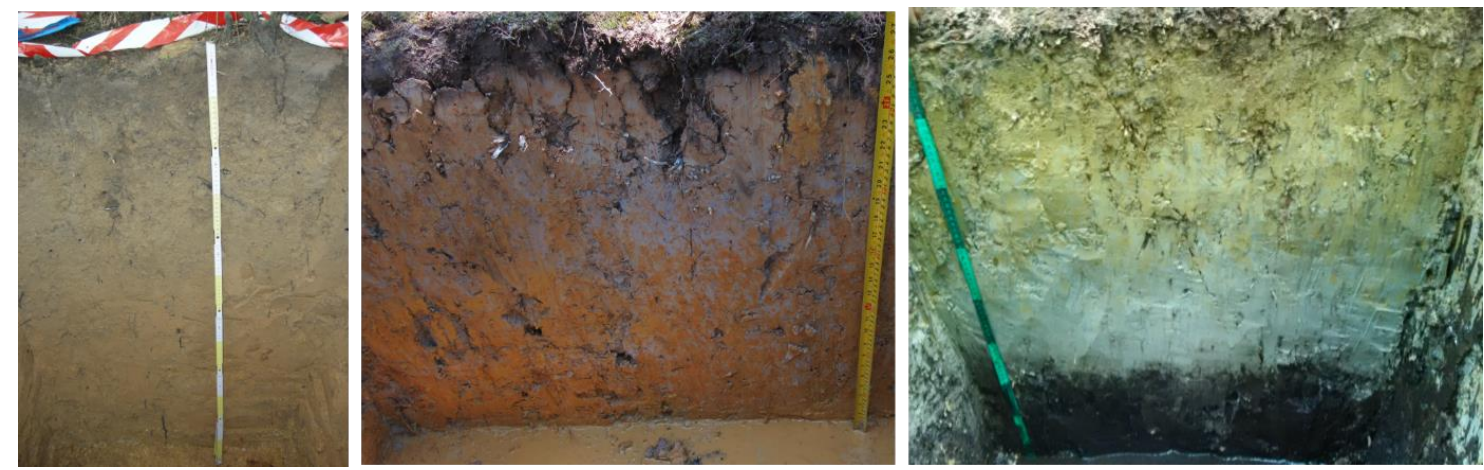

Figure 2.2-2: Typical well-drained soil profile in one of the oil palm plantations. Classified as loamic Acrisol (WRB) (left). Typical riparian soil profile in one of the oil palm plantations. Classified as loamic Stagnosol (WRB) (middle). Forest soil profile with a buried layer in the riparian forest. This soil profile differs from the usual riparian Stagnosol soil type, due to the paleo soil layer leading to different diagnostic properties (right).

In the first $0-30 \mathrm{~cm}$ of soils in riparian areas, $\mathrm{C}$ stocks decreased by $14 \%$ after forest conversion to rubber, and by $4 \%$ after conversion to oil palm plantations. However, in $0-10 \mathrm{~cm}$ depths under riparian oil palm plantations, C stocks were $20 \%$ higher than in riparian forest topsoil. Bulk density in forest topsoil was 1.2 times lower than in plantations, indicating higher soil compaction under monoculture cultivation and the absence of well-structured aggregates (Appendix, A 2.2-1). Thus, while stocks in the three land-use types did not differ significantly from each other, they indicated a tendency towards changing soil conditions after forest conversion. The riparian forest subsoil $(30-100 \mathrm{~cm})$ constituted $70 \%$ of the total C stock. In oil palm and rubber plantations, subsoil stocks made up only $42 \%$ and $44 \%$ of the total C stock, respectively.

Table 2.2-2: Soil carbon stocks in riparian and well-drained sites $(\mathrm{Mg} \mathrm{C} \mathrm{ha-1)}$

\begin{tabular}{lcccccc}
\hline & \multicolumn{3}{c}{ riparian } & \multicolumn{3}{c}{ well-drained $\neq$} \\
\hline Land use & $\mathbf{0 - 1 0} \mathbf{~ c m} \pm$ & $\mathbf{1 0 - 3 0} \mathbf{~ c m} \pm$ & $\mathbf{3 0 - 5 0}$ & $\mathbf{0 - 1 0} \mathbf{~ c m} \pm$ & $\mathbf{1 0 - 3 0} \mathbf{c m} \pm$ & $\mathbf{3 0 - 5 0}$ \\
Forest & $23.4(4.1)^{\mathrm{ab}}$ & $32.7(6.9)$ & $130.1(84.1)$ & $35.8(3.0)^{\mathrm{b}}$ & $18.6(1.8)$ & $12.7(0.7)$ \\
Rubber & $21.8(2.5)^{\mathrm{a}}$ & $26.3(2.5)$ & $37.5(2.5)$ & $21.6(1.6)^{\mathrm{a}}$ & $22.8(2.0)$ & $17.0(2.0)$ \\
Oil Palm & $28.1(4.4)^{\mathrm{ab}}$ & $25.6(6.0)$ & $39.6(3.9)$ & $20.7(2.7)^{\mathrm{a}}$ & $20.6(1.8)$ & $15.9(1.2)$ \\
\hline
\end{tabular}

‡ C stocks already published in Guillaume et al. (2015);

\pm superscripts represent significant differences according to Two-Way ANOVA with factor interaction $(p<0.05)$ between riparian and well-drained areas at 0-10 and 10-30 $\mathrm{cm}$ soil depth. Values in brackets represent the standard error of the mean (SEM). 


\subsubsection{Effect of landscape type on soil carbon stocks}

The landscape type had a significant effect on topsoil $(0-10 \mathrm{~cm}) \mathrm{C}$ stocks in forests (Figure 2.2-3a). The well-drained forest stored 53\% more $\mathrm{C}$ in its topsoil than in the riparian forest. However, C stocks in other land-use types were not affected by landscape types. The effect of landscape disappeared when including deeper soil layers (Figure 2.2-3b, c). Including depths up to $30 \mathrm{~cm}$ led to a $\mathrm{C}$ stock increase in riparian forests of $10 \mathrm{MgC} \mathrm{ha}^{-1}$, compared to $0-10 \mathrm{~cm}$ depth. This leveled out landscape effects at all sites, also when comparing 0-50 cm soil layers.

In 10-30 cm soil depths, the riparian areas showed significantly higher C stocks than welldrained areas. At any other depth interval in the subsoil, neither ecosystem type nor the interaction of ecosystem and land-use type affected C stocks (Table 2.2-2). The variance in C stocks of riparian plantations from $0-30 \mathrm{~cm}$ soil depth were up to 10 times higher than in welldrained plantations and differed significantly from each other (Levene's-test, $p=0.037$ ) (Figure 2.2-3).
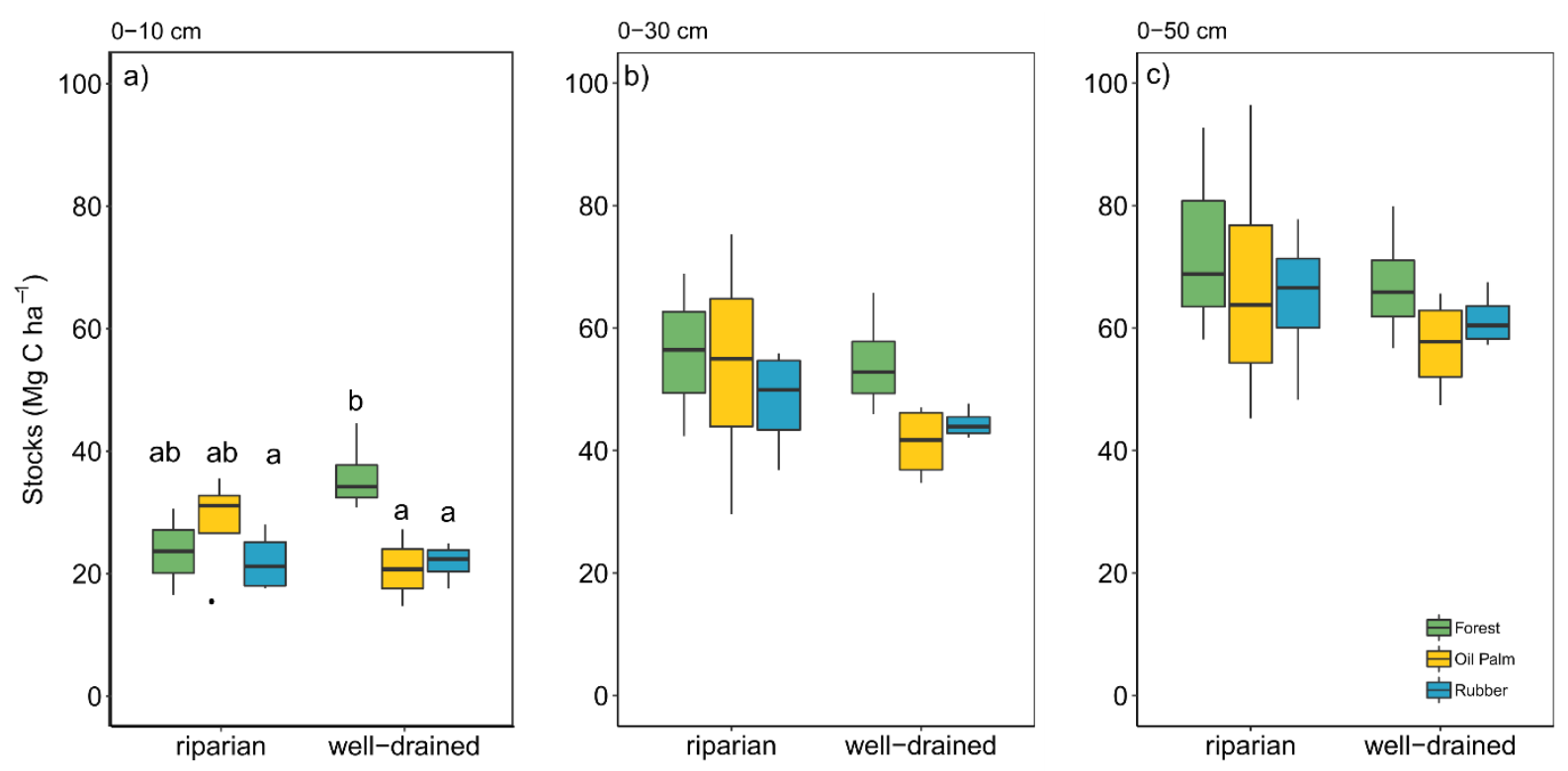

Figure 2.2-3: Carbon stocks of riparian and well-drained areas at 0-10, 0-30 and 0-50 cm soil depth. Different letters between groups indicate significant differences according to Two-Way ANOVA $(p<0.05)$.

\subsubsection{Carbon isotopic signature in riparian areas}

The lowest $\delta^{13} \mathrm{C}$ values were found in the forest topsoil's, varied between $-29.3 \%$ ond $-28.1 \%$. Under rubber and oil palm plantations, ${ }^{13} \mathrm{C}$ signatures were on average $2.3 \%$ ond $3.1 \%$ o more enriched relative to the forest and ranged between $-27.3 \%$ and $-24.9 \%$ in rubber, and between $-27.36 \%$ and $-24.40 \%$ o in oil palm plantations in riparian areas. The conversion of forest to 
monoculture tended to affect the ${ }^{13} \mathrm{C}$ signature down to $30 \mathrm{~cm}$ depth (Two-Way split-plot ANOVA, $p \leq 0.1)$. In forest subsoils $(30-100 \mathrm{~cm}), \delta^{13} \mathrm{C}$ values remained relatively stable with increasing depth, ranging between $-30 \%$ and $-28 \%$. In plantations, a heterogeneous pattern was evident: Replicates differed by up to $3.4 \%$ in oil palm plantations and $\delta^{13} \mathrm{C}$ values were more negative in the subsoil than in the topsoil.

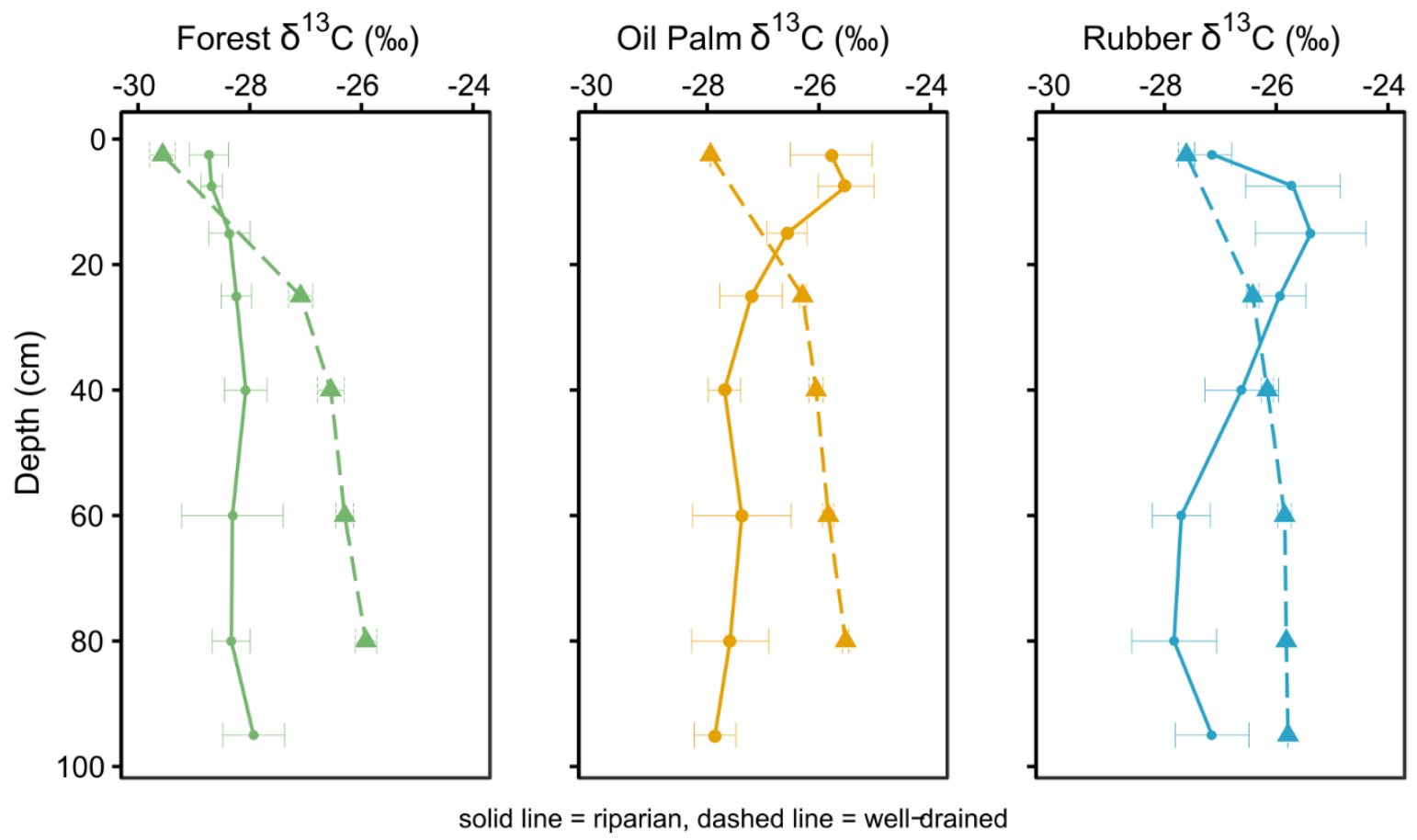

Figure 2.2-4: $\delta^{13} \mathrm{C}$ depth profiles in riparian (solid lines) and well-drained soils (dashed lines). $\delta^{13} \mathrm{C}$ values at fixed depth represent means (in forest $n=3$, in plantations $n=4$ ). Error bars indicate the standard error of the mean (SEM).

Land-use effects were also present in well-drained areas. In contrast to riparian areas, welldrained areas showed a uniform increase of ${ }^{13} \mathrm{C}$ abundance with increasing depth, which is common for undisturbed mineral soils. The $\delta^{13} \mathrm{C}$ values were lowest in the forest topsoil (- 29.6\% \pm 0.2$)$, while $\delta^{13} \mathrm{C}$ in plantation topsoil was higher $(-28.0 \%$ o \pm 0.06 under oil palm and - $27.7 \%$ o \pm 0.1 under rubber cultivation). $\delta^{13} \mathrm{C}$ in deeper soil layers aligned at $-26 \%$, with a maximum difference of $0.4 \%$ between forest and rubber plantations at $35 \mathrm{~cm}$ soil depth and $0.5 \%$ o between forest and oil palm plantations (Guillaume et al. 2015). The variance of $\delta^{13} \mathrm{C}$ in the topsoil of the riparian rubber plantations was 6 times larger than in the well-drained rubber topsoil and up to 220 times larger in deep soil. The variance of $\delta^{13} \mathrm{C}$ in soil under oil palm plantations was 77 to 220 times higher in riparian than in well-drained sites. 


\subsubsection{DISCUSSION}

\subsubsection{SOC after land-use change in riparian and well-drained areas}

The average $\mathrm{C}$ content of around $2.3 \%$ in the first $20 \mathrm{~cm}$ of riparian forest soils was similar to other hydromorphic mineral sites in tropical riverine forests (2.2\%) (Scipioni et al., 2019). However, C content was much lower than previously reported for tropical wetland forests $(6 \%$ and 35\%) (Bernal and Mitsch, 2008). This results from the fact that our riparian areas contain mineral and mucky mineral soils, whereas wetlands also contain organic soils. Consequently, C contents of our riparian areas (Figure 2.2-1) are comparable to C contents in tropical mineral soils that are not associated with wetland conditions (e.g., Chiti et al., 2014; de Blécourt et al., 2013; Guillaume et al., 2015). In temperate riparian forests similar ranges of 1.7 to $3.5 \% \mathrm{C}$ content were found (Graf-Rosenfellner et al., 2016).

The conversion from riparian forests to riparian plantations led to a small decrease in SOC contents in the upper $30 \mathrm{~cm}$, whereas large reductions of between $35 \%$ and $40 \%$ under rubber cultivation on upland mineral soils have been reported (Chiti et al., 2014; Guillaume et al., 2015). Forest transformations to oil palm plantations are often accompanied by average SOC losses between 18\% and 45\% (Chiti et al., 2014; Guillaume et al., 2018; Rahman et al., 2018; Straaten et al., 2015). All these studies were conducted in well-drained areas; however, our results indicate that riparian $C$ stocks are not that strongly affected by land-use change.

$\mathrm{C}$ content and stocks tend to higher values in deeper soil in riparian areas. The higher $\mathrm{C}$ contents in the riparian forest subsoil were likely due to buried C-rich layers, which were obvious (Figure 2.2-2). This agrees with findings of Shakhmatova and Korsunov (2008) who have described alluvial subsoil layers with strong $C$ accumulation that exceed the topsoil $C$ content. Further, abrupt changes in soil particle size in some profiles e.g., from $4 \%$ sand at $15 \mathrm{~cm}$ soil depth to $40 \%$ sand at $25 \mathrm{~cm}$ (under rubber cultivation), hint at a shift in the organic material source and confirm a spontaneous deposition event.

There is a trend to higher soil C stocks in riparian areas than in well-drained areas. Subsoil stocks $(30-100 \mathrm{~cm})$ in the riparian areas show high C stocks and reflect delayed mineralization under periodic anoxic conditions, especially in the forest with the buried layer (Gudasz et al., 2015; Hounkpatin et al., 2018; Sobek et al., 2009). High C accumulation could be further explained by the finer texture of subsoil common in Stagnosols (Zech et al., 2014). Therefore, the increasing subsoil stocks in plantations are more likely a consequence of riparian 
properties (including e.g., waterlogging and sediment transport), than of land-use change alone. Most of the soils in the investigated riparian areas, especially in plantations, were only periodically water-logged and consequently, in contrast to many wetland soils, anoxic conditions were only temporarily present. We suggest that this leads to lower C contents and stocks than we expected from other wetland ecosystems in these climatic zones (Wantzen et al., 2012).

Continuously flooded wetland ecosystems can only be used for rubber or oil palm plantations after drainage, an economically expensive and work-intensive process. In contrast, seasonal drying of riparian sites allows for easier conversion into plantations. Such sites are therefore much more likely to be subjected to large-scale land-use conversions and thus are the warrant closer study. Similar C stocks are reported by Rahman et al. (2018) who found $\sim 50 \mathrm{Mg} \mathrm{C} \mathrm{ha-1}$ in the upper $30 \mathrm{~cm}$ of a forest mineral soil in Borneo/Malaysia. Continuously flooded soils are favorable for peat formation and $\mathrm{C}$ stocks can become higher, as we found in one riparian forest plot, which was subsequently excluded from this data set. SOC stocks in the upper $30 \mathrm{~cm}$ of soil in riparian forests (Figure 2.2-3) were lower than in published studies from tropical

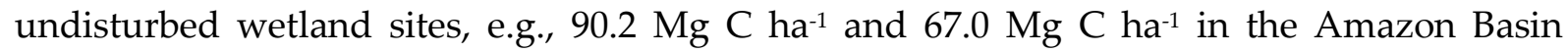
(Wantzen et al., 2012) and $80 \mathrm{Mg} \mathrm{Cha}^{-1}$ in the upper $24 \mathrm{~cm}$ of a wetland in Costa Rica (Powers, 2004).

\subsubsection{2 $\quad \delta^{13} \mathrm{C}$ elucidation of soil processes}

Using $\delta^{13} C$ values Guillaume et al. (2015) estimated $15-20 \mathrm{~cm}$ of erosive soil loss from welldrained sites within 17 years after land-use change. They assumed that $C$ content and $\delta^{13} C$ values in the plantations' subsoil were similar to the forest subsoil prior to conversion. They deduced that after the erosional loss of the upper layer, subsoil $\mathrm{C}$ content and $\delta^{13} \mathrm{C}$ values were vertically shifted towards the surface (Figure 2.2-5). The $\delta^{13} \mathrm{C}$ values in the riparian forest topsoil's were on average $2.5 \%$ o lower than in the plantations, indicating that more enriched C reaches the soil surface after conversion, induced by soil material transportation. This difference corresponds to Guillaume et al. (2015) who observed a $2 \%$ increase of $\delta^{13} \mathrm{C}$ values in the topsoil between forest and plantations. Riparian forests and plantations differ strongly in their isotopic signatures in the top- and the subsoil. Forests show more negative $\delta^{13} \mathrm{C}$ values with a more uniform depth profile than under plantations. Single replicates in the plantation's sites show a strong erratic pattern with increasing soil depth (Appendix, A 2.2-4), which hints 
at erosion and deposition bringing organic matter from various sources to the plantations (Davies et al., 2012) but the average values reveal a more homogenous $\delta^{13} \mathrm{C}$ depth profile.

The topsoil's of well-drained plantations (particularly oil palm) were more depleted in ${ }^{13} \mathrm{C}$ isotopes compared to topsoil's of riparian plantations (Figure 2.2-4). This contradicts the assumption that material from the elevated well-drained sites is steadily deposited on the lower riparian plantations. Since well-drained sites are located upstream and are heavily eroded (Guillaume et al., 2015), sedimentation on riparian sites in lower reaches would likely align their topsoil $\delta^{13} \mathrm{C}$ values. Instead, the riparian $\delta^{13} \mathrm{C}$ depth profiles indicate a more complex source-sink relationship with other processes of $C$ dynamics in the watershed. Therefore, we assume that sedimentation is a secondary pathway for topsoil $\mathrm{C}$ inputs in riparian plantations, whose actual contribution and process relationships require further investigation.

We conclude that alternating oxic and anoxic conditions mainly drive the formation of the $\delta^{13} \mathrm{C}$ depth profiles in riparian plantations. This is supported by the following: first, the riparian forest shows a uniform $\delta^{13} \mathrm{C}$ pattern (Figure 1.3-1a), which is common under constant watersaturated conditions, where anaerobic decomposition processes are dominant (Alewell et al., 2011; Krüger et al., 2014). This interpretation is supported by studies that reported more heterogeneous patterns, indicating alternating wet and dry cycles (Broder et al., 2012; Loisel et al., 2009). Second, the $\delta^{13} \mathrm{C}$ depth profile found in rubber plantations hints at aerobic decomposition down to $15 \mathrm{~cm}$, which might be caused by land-use change where the topsoil has been well-drained during conversion. The turning point to lower $\delta^{13} \mathrm{C}$ at $25 \mathrm{~cm}$ values indicates a change to saturated water conditions, and therefore a change to anaerobic decomposition and enrichment of recalcitrant material (Alewell et al., 2011). Similar $\delta^{13} \mathrm{C}$ depth profile patterns are common in peatlands (Drollinger et al., 2019; Krüger et al., 2015). In agreement with Alewell et al. (2011) and Drollinger et al. (2019), we suggest a preservation of ${ }^{13} \mathrm{C}$-depleted substances that decompose slowly under anoxic conditions, such as lignin and lipids. Third, the oil palm plantation's $\delta^{13} \mathrm{C}$ depth profile shows a turning point at $7.5 \mathrm{~cm}$ depth. Since land-use change primarily affects the upper $30-40 \mathrm{~cm}, \delta^{13} \mathrm{C}$ values in riparian and plantation's subsoils should be similar, as it was clearly shown for well-drained areas (Figure 2.2-4).

Another reason for the higher proportion of enriched ${ }^{13} \mathrm{C}$ in riparian plantations is the limited input of $\mathrm{C}$ from aboveground litter providing, less easily available material for decomposers. 
Microorganisms in the topsoil of riparian plantations have to consume strongly processed C fractions with high ${ }^{13} \mathrm{C}$ enrichment (Figure 2.2-4). In contrast to the erosion of well-drained plantations, soil $\mathrm{C}$ losses in riparian plantations are mainly controlled by mineralization processes, with potential additional fluvial erosion-deposition effects. The effect of accelerated mineralization under agricultural use extends over a longer time period and may already be detectable in the very accurate measurable $\delta^{13} \mathrm{C}$ values but not yet significant changes of the $\mathrm{C}$ stock estimates, which suffer from combined variation of bulk density and C content values. Thus, the immediate erosion after converting natural forests to plantations leads to a strong decline of $\mathrm{C}$ stocks on well-drained mineral soils, but not in riparian plantations although the riparian plantations have similar age. Hence, $\mathrm{C}$ stocks in riparian areas respond more slowly to land-use change due to 1 ) their overall slower mineralization rates under flooded conditions and 2) less erosion and partial deposition (Figure 2.2-5).

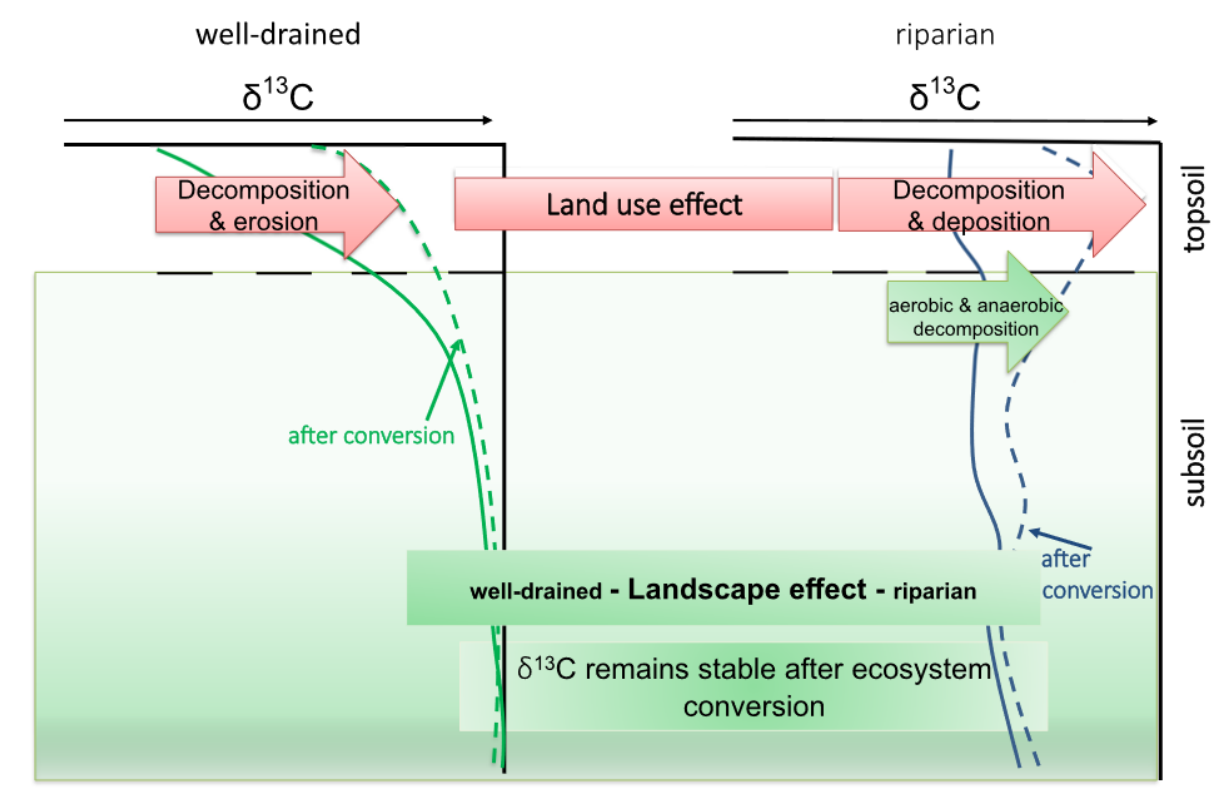

Figure 2.2-5: Impact of riparian forest conversion in combination with specific ecosystem characteristics on $\delta^{13} C$ distributions in the soil depth, separated in decomposition and erosion effects in well-drained areas (left) and decomposition and deposition as well as alternating oxic and anoxic conditions in the riparian areas (right). 


\subsubsection{CONCLUSIONS}

Land-use change in tropical regions has severe impacts on soil C stocks, due to erosion and enhanced mineralization. However, the specific geomorphic conditions in riparian areas counter these land-use effects through two dominant processes:

(1) C preservation due to oxygen-limited mineralization under alternating oxic and anoxic conditions and

(2) input and accumulation of allochthonous organic materials with various decomposition degree.

These dynamics of seasonal flooding followed by delayed mineralization are reflected by the heterogeneous $\delta^{13} \mathrm{C}$ pattern. Compared to well-drained areas, riparian areas are more resilient to short-term (1-2 decades) soil C loss after land-use change, as topsoil layers show similar C stocks compared to that under natural vegetation. However, accelerated mineralization in the topsoil indicates possible long-term effects on C storage. Riparian areas, especially if drained, have high $\mathrm{C}$ loss potential, considering the high amounts of subsoil $\mathrm{C}$ in their buried C-rich layers. Our study shows, that further research is required to deepen the understanding of the role of riparian areas in global $C$ storage and the vulnerability of these $C$ stocks under the combined effect of land-use change and riparian properties.

\section{ACKNOWLEDGEMENTS}

This study was funded by the German Research Foundation (DFG) project number 192626868 - SFB 990 in the framework of the collaborative German - Indonesian research project CRC990. We thank the following persons and organizations for granting us access to and use of their properties: local plot owners and PT REKI. This study was conducted using samples collected based on Collection Permit No. 207/SIP/FRP/E5/Dit.KI/VII/2016 recommended by the Indonesian Institute of Sciences (LIPI) and issued by the Ministry of Forestry (PHKA). The CRC990 selected the study sites. We would like to thank Kyle Mason-Jones for proofreading the manuscript, the Center for Stable Isotope Research and Analysis of the University of Göttingen for the isotopic analysis, Winda Januarista and Ardian for their support during fieldwork. 


\section{REFERENCES}

Alewell, C., Giesler, R., Klaminder, J., Leifeld, J., Rollog, M., 2011. Stable carbon isotopes as indicators for environmental change in palsa peats. Biogeosciences 8, 1769-1778. https://doi.org/10.5194/bg-8-1769-2011

Andreeva, D.B., Zech, M., Glaser, B., Erbajeva, M.A., Chimitdorgieva, G.D., Ermakova, O.D., Zech, W., 2013. Stable isotope $\left(\delta^{13} \mathrm{C}, \delta^{15} \mathrm{~N}, \delta^{18} \mathrm{O}\right)$ record of soils in Buryatia, southern Siberia: Implications for biogeochemical and paleoclimatic interpretations. Quat. Int. 290-291, 82-94. https://doi.org/10.1016/j.quaint.2012.10.054

Austin, K.G., Schwantes, A., Gu, Y., Kasibhatla, P.S., 2019. What causes deforestation in Indonesia? Environ. Res. Lett. 14, 24007. https://doi.org/10.1088/1748-9326/aaf6db

Becker, J., Pabst, H., Mnyonga, J., Kuzyakov, Y., 2015. Annual litterfall dynamics and nutrient deposition depending on elevation and land use at Mt. Kilimanjaro. Biogeosciences 12, 5635-5646. https://doi.org/10.5194/bg-12-5635-2015

Becker, J.N., Kuzyakov, Y., 2018. Teatime on Mount Kilimanjaro: Assessing climate and land-use effects on litter decomposition and stabilization using the Tea Bag Index. L. Degrad. Dev. 29, 23212329. https://doi.org/10.1002/ldr.2982

Bendix, J., Hupp, C.R., 2000. Hydrological and geomorphological impacts on riparian plant communities. Hydrol. Process. 14, 2977-2990. https://doi.org/10.1002/10991085(200011/12)14:16/17<2977::AID-HYP130>3.0.CO;2-4

Bernal, B., Mitsch, W.J., 2008. A comparison of soil carbon pools and profiles in wetlands in Costa Rica and Ohio. Ecol. Eng. 34, 311-323. https://doi.org/10.1016/j.ecoleng.2008.09.005

Biester, H., Knorr, K.H., Schellekens, J., Basler, A., Hermanns, Y.M., 2014. Comparison of different methods to determine the degree of peat decomposition in peat bogs. Biogeosciences 11, 26912707. https://doi.org/10.5194/bg-11-2691-2014

Borchard, N., Bulusu, M., Meyer, N., Rodionov, A., Herawati, H., Blagodatsky, S., Cadisch, G., Welp, G., Amelung, W., Martius, C., 2019. Deep soil carbon storage in tree-dominated land use systems in tropical lowlands of Kalimantan. Geoderma 354, 113864. https://doi.org/10.1016/j.geoderma.2019.07.022

Broder, T., Blodau, C., Biester, H., Knorr, K.H., 2012. Peat decomposition records in three pristine ombrotrophic bogs in southern Patagonia. Biogeosciences 9, 1479-1491. https://doi.org/10.5194/bg-9-1479-2012

Brown, S., Brinson, M. M., Lugo, A.E., 1978. Structure and Function of Riparian Wetlands, in: Johnson, R. R., McCormick, J.F. (Ed.), Strategies for Protection and Management of Floodplain Wetlands and Other Riparian Ecosystems. U.S. Department of Agriculture. Forest Service, Washington D.C., pp. 17-31.

Chiti, T., Grieco, E., Perugini, L., Rey, A., Valentini, R., 2014. Effect of the replacement of tropical forests with tree plantations on soil organic carbon levels in the Jomoro district, Ghana. Plant Soil 375, 47-59. https://doi.org/10.1007/s11104-013-1928-1

Ciais, P., Sabine, C., Bala, G., Bopp, L., Brovkin, V., Canadell, J., Chhabra, A., DeFries, R., Galloway, J., Heimann, M., Jones, C., Quéré, C. Le, Myneni, R.B., Piao, S., Thornton, P., 2013. Carbon and other biogeochemical cycles, Climate Change 2013 the Physical Science Basis: Working Group I Contribution to the Fifth Assessment Report of the Intergovernmental Panel on Climate Change. https://doi.org/10.1017/CBO9781107415324.015

Craig, H., 1953. The geochemistry of the stable carbon isotopes. Geochim. Cosmochim. Acta. https://doi.org/10.1016/0016-7037(53)90001-5

Davies, S.J., Leng, M.J., MacQuaker, J.H.S., Hawkins, K., 2012. Sedimentary process control on carbon isotope composition of sedimentary organic matter in an ancient shallow-water shelf succession. Geochemistry, Geophys. Geosystems 13, 1-15. https://doi.org/10.1029/2012GC004218

de Blécourt, M., Brumme, R., Xu, J., Corre, M.D., Veldkamp, E., 2013. Soil Carbon Stocks Decrease following Conversion of Secondary Forests to Rubber (Hevea brasiliensis) Plantations. PLoS One 8. https://doi.org/10.1371/journal.pone.0069357 
de Junet, A., Abril, G., Guérin, F., Billy, I., de Wit, R., 2005. Sources and transfers of particulate organic matter in a tropical reservoir (Petit Saut, French Guiana): a multi-tracers analysis using \&delta; ${ }^{13} \mathrm{C}, \mathrm{C} / \mathrm{N}$ ratio and pigments. Biogeosciences Discuss. 2, 1159-1196. https://doi.org/10.5194/bgd-2-1159-2005

de Mendiburu, F., 2017. agricolae: Statistical Procedures for Agricultural Research. R package version 1.2-8. https://doi.org/https://cran.r-project.org/package=agricolae

Décamps, H, Pinay, G, Naiman RH, Petts, GE, McClain, ME, Hillerecht-Ilkowska, A, Hanley, TA, Holmes, RM, Quinn, J, Gibert, J, Planty Tabacchi, A-M, Schiemer, F, Tabacchi, E, Zalewski, M., 2004. Riparian zones: where biogeochemistry meets biodiversity in management practice. Polish J. Ecol.

Deng, L., Wang, K., Tang, Z., Shangguan, Z., 2016. Soil organic carbon dynamics following natural vegetation restoration: Evidence from stable carbon isotopes $\left(\delta^{13} \mathrm{C}\right)$. Agric. Ecosyst. Environ. 221, 235-244. https://doi.org/10.1016/j.agee.2016.01.048

Don, A., Schumacher, J., Freibauer, A., 2011. Impact of tropical land-use change on soil organic carbon stocks - a meta-analysis. Glob. Chang. Biol. https://doi.org/10.1111/j.1365-2486.2010.02336.x

Drescher J, Rembold K, Allen K, Beckschäfer P, Buchori D, Clough Y, Faust H, Fauzi AM, Gunawan D, Hertel D, Irawan B, Jaya INS, Klarner B, Kleinn C, Knohl A, Kotowska MM, Krashevska V, Krishna V, Leuschner C, Lorenz W, Meijide A, Melati D, Nomura M, Pérez, K.H. and S.S., 2016. Ecological and socio-economic functions across tropical land use systems after rainforest conversion. Philos. Trans. R. Soc. B Biol. Sci. 371, 20150275. https://doi.org/10.1098/rstb.2015.0275

Drollinger, S., Kuzyakov, Y., Glatzel, S., 2019. Effects of peat decomposition on $\delta 13 \mathrm{C}$ and $\delta 15 \mathrm{~N}$ depth profiles of Alpine bogs. Catena 178, 1-10. https://doi.org/10.1016/j.catena.2019.02.027

Fox, J. Weisberg, S., 2011. An $\{R\}$ Companion to Applied Regression, Third Edition. Thousands OaksCA:Sage.https://doi.org/https://socialsciences.mcmaster.ca/jfox/Books/Companion/

Graf-Rosenfellner, M., Cierjacks, A., Kleinschmit, B., Lang, F., 2016. Soil formation and its implications for stabilization of soil organic matter in the riparian zone. Catena 139, 9-18. https://doi.org/10.1016/j.catena.2015.11.010

Gudasz, C., Sobek, S., Bastviken, D., Koehler, B., Tranvik, L.J., 2015. Temperature sensitivity of organic carbon mineralization in contrasting lake sediments. J. Geophys. Res. G Biogeosciences 120, 1215-1225. https://doi.org/10.1002/2015JG002928

Guillaume, T., Damris, M., Kuzyakov, Y., 2015. Losses of soil carbon by converting tropical forest to plantations: Erosion and decomposition estimated by $\delta^{13} \mathrm{C}$. Glob. Chang. Biol. 21, 3548-3560. https://doi.org/10.1111/gcb.12907

Guillaume, T., Kotowska, M.M., Hertel, D., Knohl, A., Krashevska, V., Murtilaksono, K., Scheu, S., Kuzyakov, Y., 2018. Carbon costs and benefits of Indonesian rainforest conversion to plantations. Nat. Commun. 9. https://doi.org/10.1038/s41467-018-04755-y

Guyette, R.P., Cole, W.G., Dey, D.C., Muzika, R., 2002. Perspectives on the age and distribution of large wood in riparian carbon pools. Can. J. Fish. Aquat. Sci. 59, 578-585. https://doi.org/10.1139/f02026

Harris, N.L., Brown, S., Hagen, S.C., Saatchi, S.S., Petrova, S., Salas, W., Hansen, M.C., Potapov, P. V., Lotsch, A., 2012. Baseline map of carbon emissions from deforestation in tropical regions. Science (80-. ). 336, 1573-1576. https://doi.org/10.1126/science.1217962

Hazlett, P.W., Gordon, A.M., Sibley, P.K., Buttle, J.M., 2005. Stand carbon stocks and soil carbon and nitrogen storage for riparian and upland forests of boreal lakes in northeastern Ontario. For. Ecol. Manage. 219, 56-68. https://doi.org/10.1016/j.foreco.2005.08.044

Hounkpatin, O.K.L., Op de Hipt, F., Bossa, A.Y., Welp, G., Amelung, W., 2018. Soil organic carbon stocks and their determining factors in the Dano catchment (Southwest Burkina Faso). Catena 166, 298-309. https://doi.org/10.1016/j.catena.2018.04.013

IUSS Working Group WRB, 2014. International soil classification system for naming soils and creating legends for soil maps, World Reference Base for Soil Resources 2014, update 2015. https://doi.org/10.1017/S0014479706394902 
Kassambara, A., 2020. rstatix: Pipe-friendly Framework for Basic Statistical Tests. https://doi.org/https://CRAN.R-project.org/package=rstatix

Kassambara, A., 2018. ggpubr: 2 "ggplot2" Based Publication Ready Plots. https://doi.org/https://cran.rproject.org/package $=$ ggpubr

Kelleway, J.J., Saintilan, N., Macreadie, P.I., Baldock, J.A., Ralph, P.J., 2017. Sediment and carbon deposition vary among vegetation assemblages in a coastal salt marsh. Biogeosciences 14, 37633779. https://doi.org/10.5194/bg-14-3763-2017

Kotowska MM, H.D., Triadiati T, Selis M, L.C., 2015. Quantifying above- and belowground biomass carbon loss with forest conversion in tropical lowlands of Sumatra (Indonesia). Glob. Chang. Biol. 21, 3620-3634. https://doi.org/10.1111/gcb.12979

Krüger, J.P., Leifeld, J., Alewell, C., 2014. Degradation changes stable carbon isotope depth profiles in palsa peatlands. Biogeosciences 11, 3369-3380. https://doi.org/10.5194/bg-11-3369-2014

Krüger, J.P., Leifeld, J., Glatzel, S., Szidat, S., Alewell, C., 2015. Biogeochemical indicators of peatland degradation - A case study of a temperate bog in northern Germany. Biogeosciences 12, 28612871. https://doi.org/10.5194/bg-12-2861-2015

Labrière, N., Locatelli, B., Laumonier, Y., Freycon, V., Bernoux, M., 2015. Soil erosion in the humid tropics: A systematic quantitative review. Agric. Ecosyst. Environ. https://doi.org/10.1016/j.agee.2015.01.027

Laumonier, Y., 1997. The Vegetation and Physiography of Sumatra. Springer Netherlands, Dordrecht. https://doi.org/10.1007/978-94-009-0031-8_1

Loisel, J., Garneau, M., Hélie, J.F., 2009. Modern Sphagnum $\delta^{13} \mathrm{C}$ signatures follow a surface moisture gradient in two boreal peat bogs, James Bay lowlands, Québec. J. Quat. Sci. 24, 209-214. https://doi.org/10.1002/jqs.1221

Margono, B.A., Potapov, P. V, Turubanova, S., Stolle, F., Hansen, M.C., 2014. Primary forest cover loss in indonesia over 2000-2012. Nat. Clim. Chang. https://doi.org/10.1038/nclimate2277

McCormick, J.F., 1978. A summary ofthe national riparian symposium., in: Johnson, R.R. McCormick, J.F. (Ed.), Strategies for Protection and Management of Floodplain Wetlands and Other Riparian Ecosystems. Washington D.C., pp. 362-363.

Meyer, N., Welp, G., Rodionov, A., Borchard, N., Martius, C., Amelung, W., 2018. Nitrogen and phosphorus supply controls soil organic carbon mineralization in tropical topsoil and subsoil. Soil Biol. Biochem. 119, 152-161. https://doi.org/10.1016/j.soilbio.2018.01.024

Miettinen, J., Shi, C., Liew, S.C., 2011. Deforestation rates in insular Southeast Asia between 2000 and 2010. Glob. Chang. Biol. 17, 2261-2270. https://doi.org/10.1111/j.1365-2486.2011.02398.x

Moore, S., Evans, C.D., Page, S.E., Garnett, M.H., Jones, T.G., Freeman, C., Hooijer, A., Wiltshire, A.J., Limin, S.H., Gauci, V., 2013. Deep instability of deforested tropical peatlands revealed by fluvial organic carbon fluxes. Nature 493, 660-663. https://doi.org/10.1038/nature11818

Powers, J.S., 2004. Changes in soil carbon and nitrogen after contrasting land-use transitions in northeastern Costa Rica. Ecosystems 7, 134-146. https://doi.org/10.1007/s10021-003-0123-2

$\mathrm{R}$ Core Team, 2018. R: A language and environment for statistical computing. $\mathrm{R}$ Foundation for Statistical Computing, Vienna, Austria. https://doi.org/https://www.R-project.org/

Rahman, N., De Neergaard, A., Magid, J., Van De Ven, G.W.J., Giller, K.E., Bruun, T.B., 2018. Changes in soil organic carbon stocks after conversion from forest to oil palm plantations in Malaysian Borneo. Environ. Res. Lett. 13. https://doi.org/10.1088/1748-9326/aade0f

Rieger, I., Lang, F., Kowarik, I., Cierjacks, A., 2014. The interplay of sedimentation and carbon accretion in riparian forests. Geomorphology 214, 157-167. https://doi.org/10.1016/j.geomorph.2014.01.023

Scharlemann, J.P.W., Tanner, E.V.J., Hiederer, R., Kapos, V., Pw, J., Tanner, E.V.J., Hiederer, R., Kapos, V., 2014. Global soil carbon: understanding and managing the largest terrestrial carbon pool Global soil carbon: understanding and managing the largest terrestrial carbon pool 3004. https://doi.org/10.4155/cmt.13.77

Scipioni, M.C., de Araújo Pedron, F., Longhi, S.J., Galvão, F., Budke, J.C., Schneider, P.R., 2019. Natural channeling in riverine forests determines variations in their floristic composition, structure, and 
land use in southern Brazil. Landsc. Ecol. Eng. 15, 347-362. https://doi.org/10.1007/s11355-01900385-8

Shakhmatova, E.Y., Korsunov, V.M., 2008. Buried humus horizons of flooded soils of the Selenga river delta. Geogr. Nat. Resour. 29, 338-342. https://doi.org/10.1016/j.gnr.2008.10.012

Sobek, S., Durisch-Kaiser, E., Zurbrugg, R., Wongfun, N., Wessels, M., Pasche, N., Wehrli, B., 2009. Organic carbon burial efficiency in lake sediments controlled by oxygen exposure time and sediment source. Limnol. Oceanogr. 54, 2243-2254. https://doi.org/10.4319/lo.2009.54.6.2243

Sprecher, S.W., 2001. Basic Concepts of Soil Science, in: Richardson, J.L.; Vepraskas, M.J. (Ed.), Wetland Soils. Genesis, Hydrology,Landscapes and Classificaion. Lewis Publishers, Boca Raton, London, New York, Washington D.C., pp. 3-19.

Straaten, O. van, Corre, M.D., Wolf, K., Tchienkoua, M., Cuellar, E., Matthews, R.B., Veldkamp, E., 2015. Conversion of lowland tropical forests to tree cash crop plantations loses up to one-half of stored soil organic carbon. Proc. Natl. Acad. Sci. 112, 9956-9960. https://doi.org/10.1073/PNAS.1504628112

Wantzen, K.M. Yule Catherine M., Trockner Klement, J.W.J., 2008. Riparian Wetlands of Tropical Streams, in: Dudgeon, D. (Ed.), Tropical Stream Ecology. Elsevier Inc. Academic Press, pp. 3035-3044. https://doi.org/10.1016/B978-008045405-4.00352-9

Wantzen, K.M., Couto, E.G., Mund, E.E., Amorim, R.S.S., Siqueira, A., Tielbörger, K., Seifan, M., 2012. Soil carbon stocks in stream-valley-ecosystems in the Brazilian Cerrado agroscape. Agric. Ecosyst. Environ. 151, 70-79. https://doi.org/10.1016/j.agee.2012.01.030

Wickham, H., 2017. tidyverse: Easily Install and Load the "Tidyverse". https://doi.org/https://CRAN.Rproject.org/package=tidyverse

Wickham, H., 2016. ggplot2: Elegant Graphics for Data Analysis. Springer Verlag. New York.

Zang, H., Blagodatskaya, E., Wen, Y., Xu, X., Dyckmans, J., Kuzyakov, Y., 2018. Carbon sequestration and turnover in soil under the energy crop Miscanthus: repeated $13 \mathrm{C}$ natural abundance approach and literature synthesis. GCB Bioenergy 10, 262-271. https://doi.org/10.1111/gcbb.12485

Zech W, Schad P, Hintermaier-Erhard, G., 2014. Böden der Welt. Ein Bildatlas, Second Edi. ed. Springer Spektrum, Berlin, Heidelberg. https://doi.org/https://doi.org/10.1007

Zehetner, F., Lair, G.J., Gerzabek, M.H., 2009. Rapid carbon accretion and organic matter pool stabilization in riverine floodplain soils. Global Biogeochem. Cycles 23, 1-7. https://doi.org/10.1029/2009GB003481 


\section{APPENDIX}
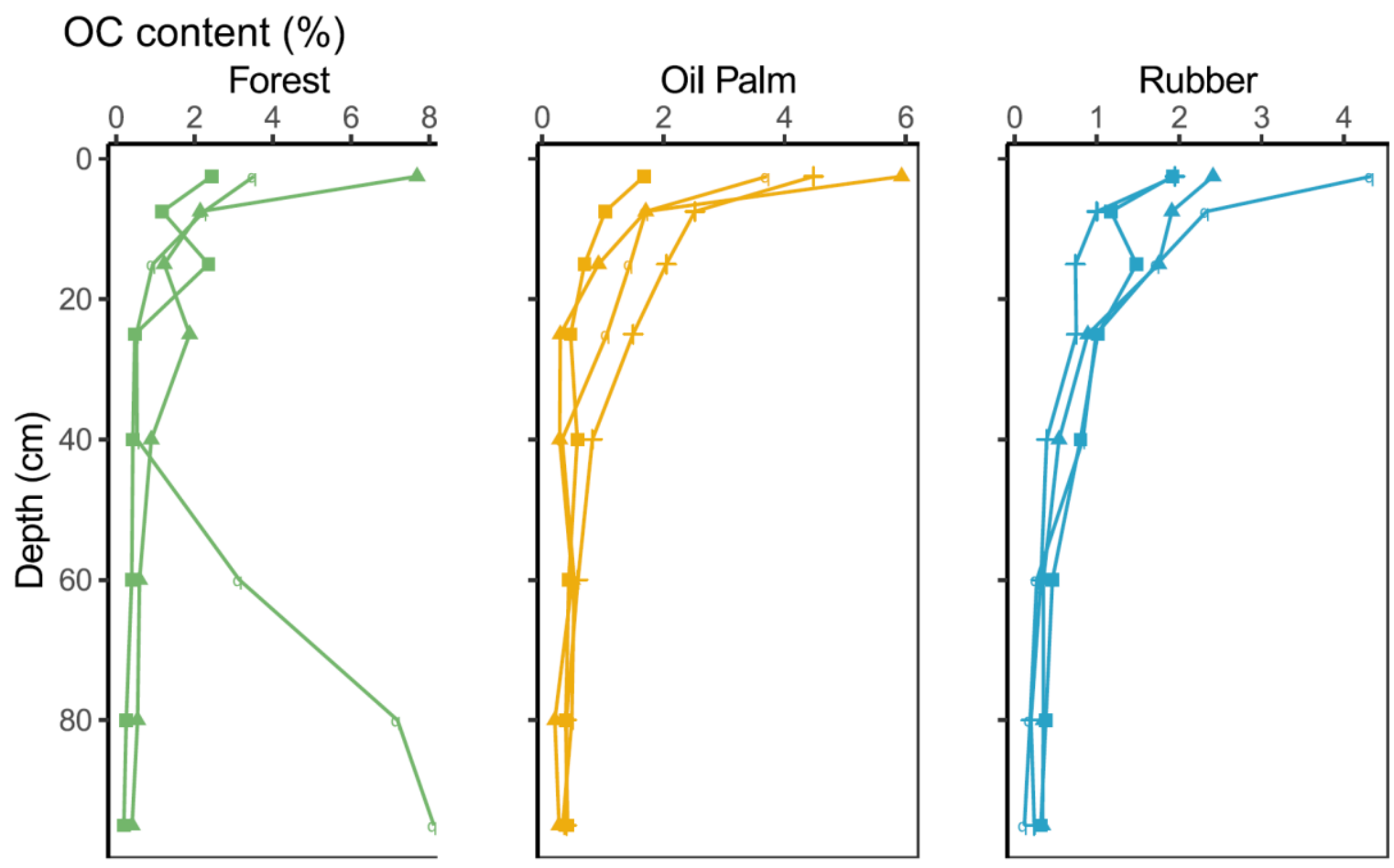

A 2.2-1: OC content (\%) in riparian areas shows heterogeneity between the replicates

\section{OC content $\left(\mathrm{g} \mathrm{C} \mathrm{kg}^{-1}\right)$}
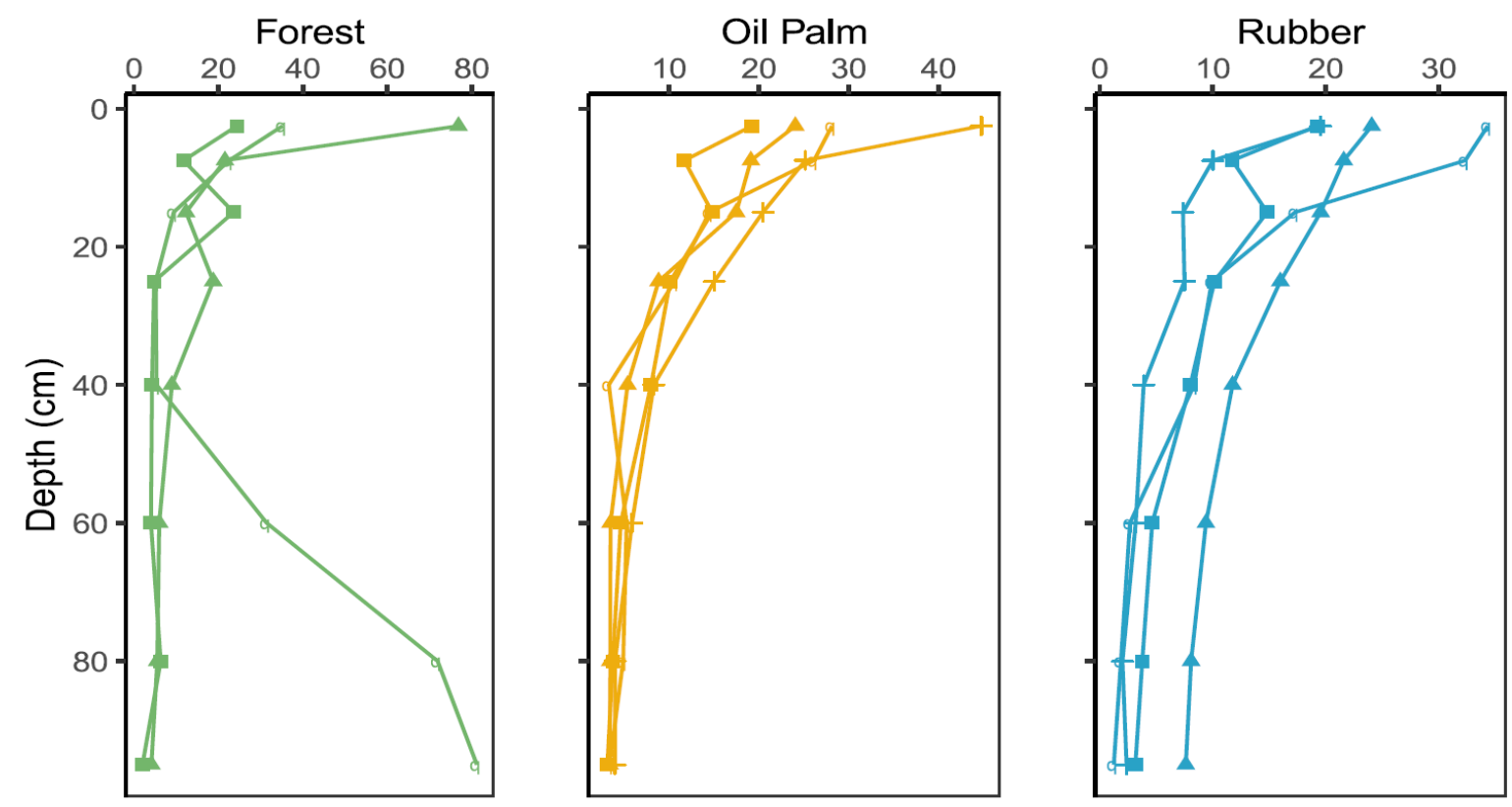

A 2.2-2: OC content $\left(\mathrm{g} C \mathrm{~kg}^{-1}\right)$ in riparian areas shows heterogeneity between the replicates 


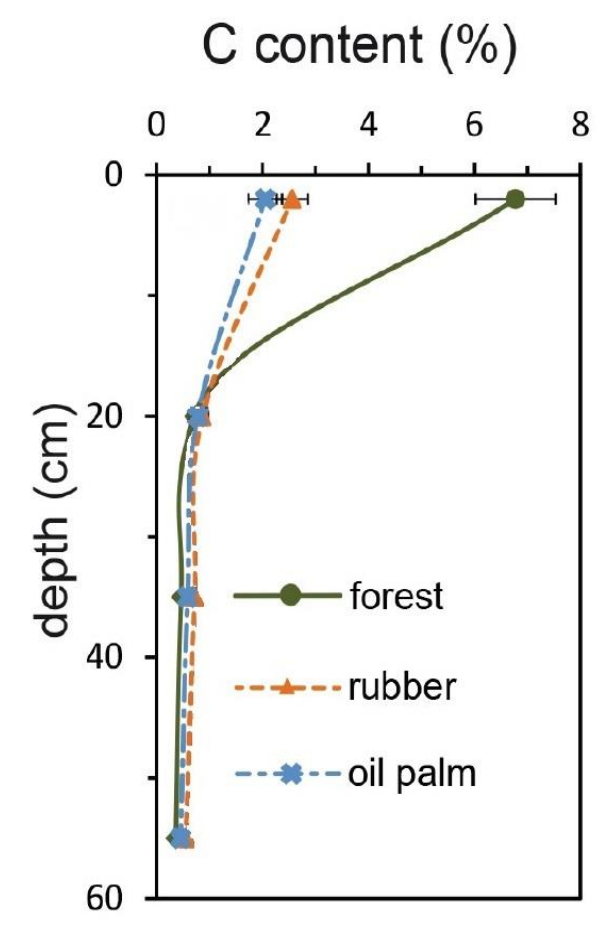

A 2.2-3: OC content (\%) in well-drained areas, already published in Guillaume et al. (2015)
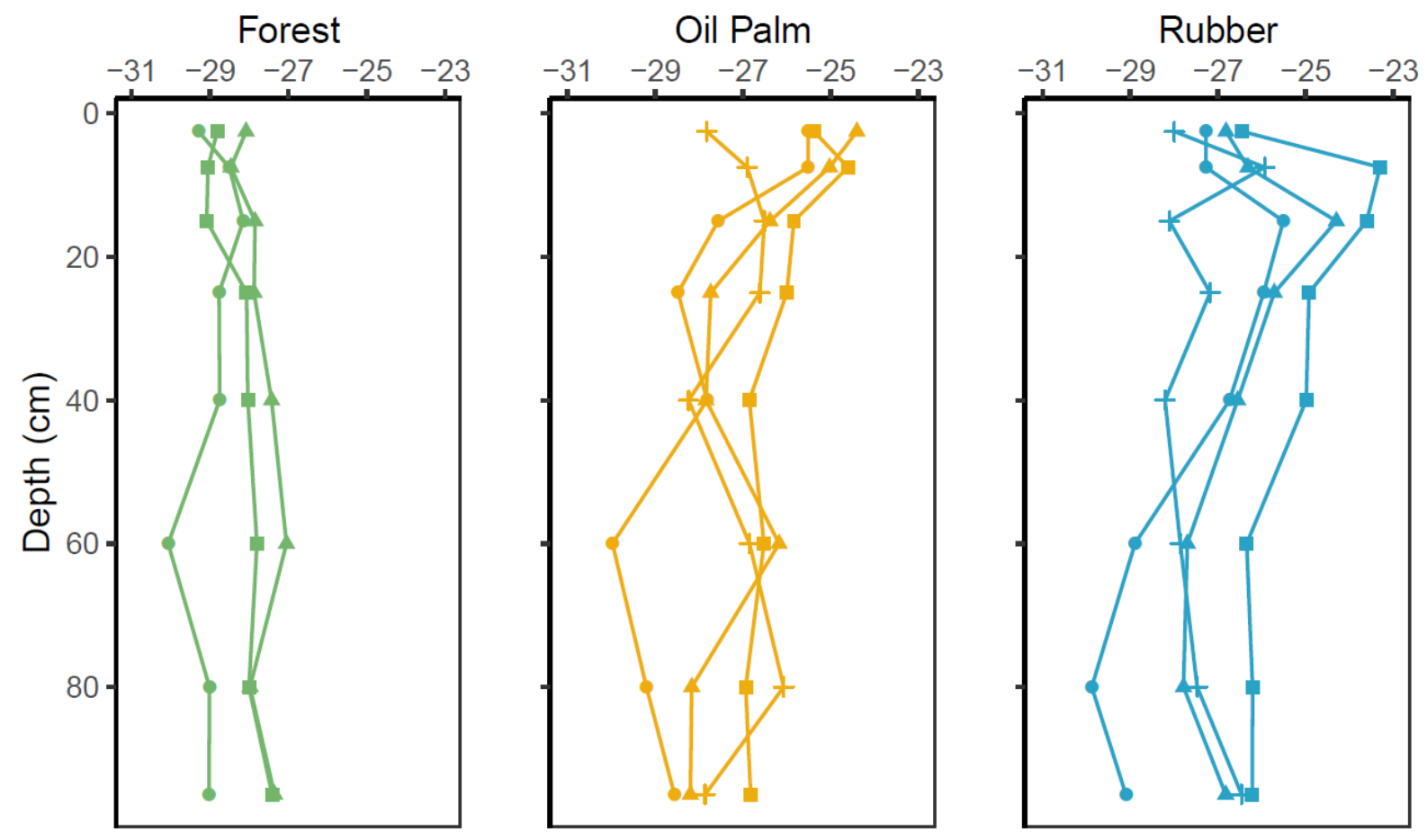

A 2.2-4: $\delta^{13} \mathrm{C}$ values (\%) in riparian areas show a high heterogeneity between the replicates 
A 2.2-5: Average riparian bulk densities $\left(\mathrm{g} \mathrm{cm}^{-3}\right)( \pm$ indicate the Standard Error of Mean (SEM))

\begin{tabular}{llll}
\hline soil depth (cm) & Forest & Rubber & Oil Palm \\
\hline & & & \\
& & & \\
2.5 & 0.7 & 1.1 & 1.00 \\
& $( \pm 0.1)$ & $( \pm 0.1)$ & $( \pm 0.1)$ \\
7.5 & 1.1 & 1.1 & 1.1 \\
& $( \pm 0.1)$ & $( \pm 0.1)$ & $( \pm 0.0)$ \\
15 & 1.3 & 1.1 & 1.2 \\
& $( \pm 0.1)$ & $( \pm 0.0)$ & $( \pm 0.1)$ \\
25 & 1.3 & 1.2 & 1.3 \\
& $( \pm 0.0)$ & $( \pm 0.1)$ & $( \pm 0.1)$ \\
40 & 1.4 & 1.3 & 1.4 \\
& $( \pm 0.1)$ & $( \pm 0.1)$ & $( \pm 0.0)$ \\
60 & 1.3 & 1.4 & 1.3 \\
& $( \pm 0.1)$ & $( \pm 0.1)$ & $( \pm 0.0)$ \\
80 & 1.2 & 1.4 & 1.2 \\
& $( \pm 0.1)$ & $( \pm 0.1)$ & $( \pm 0.00)$ \\
95 & 1.2 & 1.4 & 1.2 \\
& $( \pm 0.1)$ & $( \pm 0.1)$ & $\pm 0.0)$ \\
& & & \\
\hline
\end{tabular}




\subsection{Reconstructing the sources of soil organic matter after land- use change in Indonesia using a multiple biomarker approach}

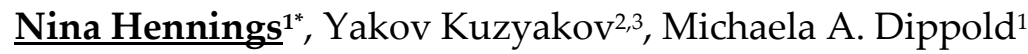

Status: Manuscript in preparation

${ }^{1}$ Biogeochemistry of Agroecosystems, University of Göttingen, Büsgenweg 2, 37077 Göttingen

${ }^{2}$ Soil Science of Temperate Ecosystems, University of Göttingen, Büsgenweg 2, 37077 Göttingen

${ }^{3}$ Department of Agricultural Soil Science, University of Göttingen, Büsgenweg 2, 37077 Göttingen

*Corresponding author: Nina Hennings, Biogeochemistry of Agroecosystems, University of Göttingen, Büsgenweg 2, 37077 Göttingen, Germany. E-mail: nina.hennings@forst.unigoettingen.de, Telephone: +49 (0) 5513912294 


\subsubsection{ABSTRACT}

Tropical forest conversion to agricultural monocultures such as rubber and oil palm plantations causes severe soil organic carbon (SOC) losses. It is unclear how much of the stored carbon (C) after land-use change still originates from the past vegetation of rainforest and which proportion of soil C originates already from plantation vegetation. Plant-derived lipids are molecular biomarkers that can provide insights into present and past SOC input and its degree of degradation within soil. To examine whether soils from plantations reflect recent and/or past vegetation, we compared soil lipids comprising n-alkanes, carboxylic acids, alcohols and ketons in litter, roots and soil samples from primary rainforest, rubber and oil palm plantations from Sumatra/Indonesia. Ordination analysis with subsequent indicator species analysis revealed specific organic compounds in plantations' soils, indicating plant- as well as microbial-derived C sources. Biomarkers assigned to microbial origin were i15:0 and

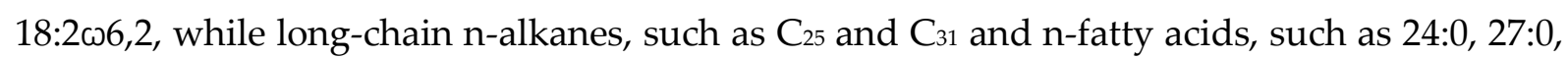
28:0 and 29:0 were attributed to plant material. Long-chain fatty acids, such as 24:0, have similar abundances between forests and plantations due to their long-chain $C$ compounds and the associated high resistance to biodegradation. Odd-chain fatty acids like 27:0 and 29:0 are rather the products of microbial transformation of even-chain plant-derived fatty acids. However, other indicators e.g., clear odd-over-even-predominance (between $C_{27}-C_{31}$ ) of the alkane pattern and even-over-odd predominance of the $\mathrm{n}$-fatty acids point to a high proportion of still untransformed plant-derived SOC. Similar abundances of 16-OH-16:0 were found in all soils of the three land-use and could be clearly attributed to forest litter. This substance made up a significant proportion of all hydroxy fatty acid substances with $32 \%$. Our study showed that lipid biomarkers can be used to discover the sources and fluctuations in the molecular composition of SOC in plantations after land-use change. Further, we conclude that n-alkanes, fatty acids and hydroxy fatty acids were more suitable as lipid proxy than aliphatic alcohols.

Keywords: biomarkers, free lipids, n-alkanes, land-use change, oil palm, SOC 


\subsubsection{INTRODCTION}

The expansion of agriculture has been one of the most significant changes in land use and has increased vastly in intensity and on scale over the past centuries (Gibbs et al., 2010; Song et al., 2018). Indonesia is one of the countries with the highest forest conversion rates worldwide (Margono et al., 2014). Between 2001 and 2016 Indonesia lost $~ 52 \%$ of rainforest by conversion to agricultural land, mainly to large scale plantations such as rubber (Hevea brasiliensis) and oil palm (Elaeis guineensis) monocultures (Austin et al., 2019). Expansion of plantations proceeded in less accessible areas such as riparian areas, which are characterized by periodically flooding through a river stream (Merten et al., 2021, 2020). This land-use change is the greatest driver of C losses from mineral soils, as various studies showed (Borchard et al., 2019; de Blécourt et al., 2013). Under rubber and especially oil palm cultivation C input is strongly reduced (Guillaume et al., 2016a, 2015) and the initial SOC losses due to forest conversion cannot be balanced out (Smith et al., 2012). The main sources of soil organic matter (SOM) in mineral soils and riparian systems originate from above- and belowground plant tissues as well as microbial biomass. Leaf litter and roots are degraded and incorporated into soil via the soil fauna (Angst et al., 2016; Kögel-Knabner, 2002). Belowground inputs are rhizodeposits that are directly provided to the soil (Blagodatsky and Richter, 1998). After the conversion of forest to plantations, the number of trees and fine root mass is massively reduced (Rembold et al., 2017; Sahner et al., 2015) , implying a reduction of C input into soil.

To identify C sources and their contribution to SOC, lipids, specifically n-alkyl lipids can serve as valuable biomarkers to disentangle the origin of SOC, i.e., plant versus microbial biomass. Soil lipids in average constitute only $4-8 \%$ of SOC globally (Dinel and Schnitzer, 2000), while they have a high diagnostic value. These organic compounds with a defined structure serve as partially very specific biomarkers indicative for its producer and help to reconstruct the pathways and transformations of SOC (Otto and Simpson, 2005). Proxies for terrestrial vegetation are higher plant leaf wax compounds i.e., hydrocarbons, alcohols and acids, with a high specificity for plant origin at a chain length of $>20 \mathrm{C}$ (Collister et al., 1994). N-alkanes as part of aliphatic hydrocarbons and their precursors, i.e., carboxylic and hydroxy carboxylic acids are especially suitable as biomarkers because of their strong resistance to biodegradability which coincides with long- $\mathrm{C}$ chains (compounds with $>20 \mathrm{C}$ atoms), and a strong odd-over-even predominance (OEP), a pronounced water insolubility, chemical inertness and a negligible volatility (Collister et al., 1994; Eglinton and Eglinton, 2008). Because 
of these characteristics they can be preserved for a very long time in soil and serve as biomarkers not only for the reconstruction of C source (Wiesenberg et al., 2010) but are also a common tool to reconstruct vegetation history and paleoenvironments(e.g. Chen et al., 2021; Zech et al., 2012, 2010). The strong OEP, typically in the range between $C_{25}$ and $C_{33}$ serves as a molecular marker to determine organic matter degradation. Higher values $(<5)$ indicate fresh, undegraded material, such as litter, while lower values $(<5)$ hint at already advanced degraded material, such as topsoil (Zech et al., 2012). Further a dominance of $C_{31}$ and $C_{33}$ in the n-alkane pattern is assigned to herb and grass origin and a dominance of $C_{27}$ and $C_{29}$ is attributed to trees and shrubs (Meyers, 2003). Long-chain fatty acids samples with an evenover-odd predominance (EOP) are expected, displayed by the carbon preference index (CPI) representing surface waxes in higher plants (Kolattukudy et al., 1976). Further molecular proxies in fatty acids are found to elucidate plant versus microbial origin, such as the ratio $\mathrm{C}_{16: 1+2}{ }^{*} \mathrm{C}_{16: 0^{-1}}$ (Harwood and Russel, 1984; Wiesenberg et al., 2010), where a ratio $<0.1$ indicates a contribution of microbial-derived compounds to the total amount of fatty acids. Compared to microbial biomass, plant tissues are known to be depleted in $\mathrm{C}_{16: 1+2}$ and show a ratio $<0.1$. Additionally, the average chain length (ACL) of fatty acids can be used as a proxy for the degradation stage and the fatty acid origin in soil. OM derived from microbial sources is characterized by a lower ACL, due of the absence of long-chain fatty acids (> 20 C). The stage of degradation is displayed by an decrease of short-chain fatty acid compounds, accompanied by a selective enrichment of long-chain fatty acids, resulting in higher ACL with advanced degradation (Wiesenberg et al., 2010). In case of a distinct lipid pattern of the forest, rubber and oil palm, these biomarkers may be suitable to trace $C$ in plantations after land-use change and to estimate the contribution of past vegetation forms.

Therefore, our study aims to reveal 1) the contribution of past vegetation to the current SOC pool and 2) to determine changes in SOM composition in rubber and oil palm plantations Further, we aimed to 3) explore whether we can identify specific biomarkers for oil palm or rubber plants and to 4) identify indicative microbial biomarkers which allow conclusions about necromass contribution. Based on previous findings we hypothesized 1) substances present in significantly lower amounts in forest soils, litter and/or roots, than in rubber and/or oil palm plantations soils and litter and/or roots can be identified as $\mathrm{C}$ input sources after forest conversion and might be a specific biomarker representative for rubber and oil palms as well as soils. We hypothesise 2) that specific biomarkers do not differ in abundance between forest 
and plantation soils, if past forest vegetation continues to have a significant effect on present SOM composition in rubber and/or oil palm plantations. We hypothesize 3) after land-use change a relatively decrease in litter $\mathrm{C}$ input leads to a relative increase in micobial biomass and consequently to microbial necromass contribution to SOM.

\subsubsection{MATERIALS AND METHODS}

\subsubsection{Study Area}

Sampling was carried out in the Province of Jambi in Sumatra, Indonesia. Jambi's climate is tropical humid with an average annual temperature of $27.6^{\circ} \mathrm{C}$ and an average annual rainfall of $2235 \mathrm{~mm}$. The rainy season has two peak periods (March and December) and an average monthly rainfall of $261 \mathrm{~mm}$, followed by a drier period between April and September with a monthly rainfall of $161 \mathrm{~mm}$ (Drescher et al., 2016). The natural vegetation of the lowlands in Jambi is a mixed dipterocarp rainforest (Laumonier, 1997) (are there predominant species? For a biomarker paper on vegetation that might be good to add). The investigated land-use systems include disturbed primary rainforest within riparian areas, used as reference sites, and intensive monocultural rubber (Hevea brasiliensis) and oil palm (Elaeis guineensis) plantations within riparian areas. Plantations managed by smallholder farmers varied between 8-18 years (rubber) and 10-16 years (oil palm) in stand age. In each of the land use systems four 50x50 m plots were established (12 plots in total) (Drescher et al., 2016). The soils were classified as Gleysols, Stagnosols and stagnic Acrisols with a loamic and clayic texture (Hennings et al., 2021).

\subsubsection{Field Sampling}

Since Hennings et al., (2021) identified C preservation and only small SOC losses from the topsoil in riparian areas after land-use change, we focused our analysis on the top $10 \mathrm{~cm}$, thereby combining the top two samples from the soil profiles, which were collected in $5 \mathrm{~cm}$ intervals. Soil samples in oil palm plantations were sampled in the interrows, the path between the palm rows.

\subsubsection{Biomarker analysis}

n-alkanes, fatty acids, hydroxy fatty acids and n-alcohols/ketone fractions of free lipids were used as specific biomarkers for studying the degradation and possible preservation of leaf waxes from vascular plants in SOM. They were extracted by following a modified version of 
Birk et al., (2012) and was combined with integrating elements suggested by Wiesenberg et al., (2004). $10 \mathrm{~g}$ of dried and ground soil were weighed into Soxhlet thimbles for free lipid extraction by a Soxhlet apparatus. Extraction was done for $36 \mathrm{~h}$ in a 2:1 mixture of dichlormethane (DCM) and methanol (MeOH). Extracted free lipids were spiked with internal standards (hexatriacontane for n-alkanes, 2-pentadecanone for ketones, 1-nonadecanol for nalcohols, nervonic acid for fatty acids, 12-OH stearic acid for hydroxy fatty acids). Although individual internal standards for n-alcohols and ketones were added, both groups of substances were extracted as one fraction accounting for the difficulties in their separation as result of the keto-enol-tautomerization. Subsequently, in a separation funnel the free lipid solvent was separated into the neutral and the acid fraction by a liquid-liquid extraction. For this, $20 \mathrm{ml}$ water was added to the solvent to achieve a phase separation and the $\mathrm{pH}$ was adjusted to a $\mathrm{pH}$ of 10 by $1 \mathrm{M} \mathrm{NaOH}$ in $\mathrm{MeOH}$ to collect the neutral fraction and thereafter to 2 by $6 \mathrm{M} \mathrm{HCl}$ to collect the acid fraction. Both fractions were obtained by three liquid-liquid extractions with chloroform. Solvents were vaporized by a rotary evaporator and stored at -20 ${ }^{\circ} \mathrm{C}$ before further analyses. To obtain the n-alkane and the n-alcohol/ketones fraction, the neutral fraction was separated by solvents of different polarities via SPE columns (high purity grade silica gel in n-hexane, Sigma Alderich, Munich, Germany). Alkanes did not bind to the silica gel, passed through with $30 \mathrm{ml}$ of hexane and were collected. Ketones, n-alcohols and the aromatic fraction were summarized and eluted by $30 \mathrm{ml}$ 2:1 hexane:DCM, $30 \mathrm{ml} \mathrm{DCM}$ and $50 \mathrm{~mL} \mathrm{MeOH}$. All solvents were vaporized, and the dried samples were stored again at $-20^{\circ} \mathrm{C}$. The acid fraction (carboxyl groups) was methylated $\left(\mathrm{BF}_{3}\right.$ in $\left.\mathrm{MeOH}\right)$ and separated on a activated silica gel SPE into the fatty acid fraction (10 $\mathrm{ml}$ 2:1 DCM:hexane) and hydroxy fatty acid fraction $(30 \mathrm{ml} \mathrm{MeOH})$. The hydroxyl groups and the ketones were acetylated (acetic anhydride:pyridine). All fractions were dried and re-dissolved in $185 \mu$ l toluene, and $15 \mu \mathrm{l}$ of a second internal standard (methyl tridecanoate) was added. External standards for all lipid fractions were methylated or acetylated according to the corresponding samples and used for later quantification.

For substance separation and identification, measurements were performed by gas chromatography on Agilent 7820A or 7890A GCs. The Agilent 7890A GC was coupled to an Agilent 7000A triple quadrupole mass spectrometer (Agilent, Waldbronn, Germany). Unknown peaks with high abundances were identified via the NIST database (NIST mass 
spectral library 08 and NIST mass spectral search program Version 2.0f), and in case of substance class but no exact monomer could be identified numbered (i.e., $\mathrm{C}_{30} \mathrm{H}_{50}$ Derivate 1).

\subsubsection{Calculations and Statistics}

All substance contents were calculated as described in Birk et al. (2012) and were converted to relative abundances in relation to the total compound contents of the individual fractions. Three molecular proxies were used to assess the source of free lipids at the molecular level. We used the OEP as it is known that higher plants are quantitatively dominated by long-chain homologues in the range of $\mathrm{C}_{27}-\mathrm{C}_{33}$ and exhibited a strong OEP (Eglinton and Hamilton, 1967). Additionally, we associated an n-alkane $\mathrm{C}_{27}$ and $\mathrm{C}_{31}$ dominance to grass and herb origin and a $\mathrm{C}_{27}$ and $\mathrm{C}_{29}$ dominance to tree and shrub origin (Zech et al., 2009). Given that a dominance of long-chain n-alkanes indicates plant origin the average chain length (ACL) was calculated following Equation (1):

$$
\mathrm{ACL}=\sum\left(C_{n} * n\right) / \sum\left(C_{n}\right)
$$

where $C_{n}$ is the concentration of each n-alkane between $C_{16}$ and $C_{35}$ (Bush and McInerney, 2013). In accordance with Wiesenberg et al. (2010) and based on Harwood \& Russel (1984) the C16:1+2 ${ }^{*} \mathrm{C}_{16: 0^{-1}}$ ratio of fatty acids were calculated, where a value $>0.1$ indicates the contribution of microbial-derived compounds. All statistics and graphing were performed by the statistical software RStudio 1.4.1103 (R Core Team, 2018). Restructering and aggregating data were performed by using the reshape2 (Wickham, 2007) and dplyr (Wickham et al., 2020) packages, graphing was done by using the package ggplot2 (Wickham, 2016). Visualization of similarities between substances of each free lipid fraction in soil, litter and root samples was performed using a non-metric multidimensional scaling (NMDS) based on Bray-Curtis dissimilarity matrix. The NMDS plots were created using the metaMDS function from the $\mathrm{R}$ package vegan (Oksanen et al., 2019). The ANalysis Of SIMilarities (ANOSIM, $p<0.05$ ) tests were performed to test for significant differences in the free lipid fraction assemblages of various groups such as topsoil, litter and roots. The ANOSIM tests were performed on the same data used for generation of the NMDS plots, using the function anosim, from the $R$ package vegan. To identify indicator substances, defined as single or small groups of free lipids which represent a specific land use, soil depth or C source (soil, litter, root), we used the multipatt function from the indicspecies package in R (De Cáceres and Legendre, 2009), using the point-biserial correlation index. Indicator substances may be used to detect shifts in free 
lipid composition and abundance after land-use changes. To test significant differences of the indicator substance between soil, litter and roots in three different land-use type, One-Way ANOVAs $(p<0.05)$ were performed for each $C$ pool, followed by a Tukey-post hoc analysis for group comparisons (TukeyHSD, $p>0.05$ ) with Bonferroni correction. The One-Way ANOVA, the Tukey-post hoc test as all as variance the homogeneity between groups (Levene's test, $p>0.05$ ) and the normal distribution (shaprio.wilk, $p>0.05$ ) were tested using the packages car (Fox and Weisberg, 2011), multcompview (Graves et al., 2019) and lsmeans (Lenth, 2016a). Occasional deviations from the normality assumption of groups were small and considered acceptable given the robustness of a homoscedastic ANOVA.

\subsubsection{RESULTS}

\subsubsection{Comparison of free lipids from different $C$ pools in forest, rubber and oil palm plantations}

A comparison of the substance composition, performed separately for the monomers of each four lipid fractions analyzed, of soil, litter and roots of forest, rubber and oil palm plantations showed that a separation of the samples that was rather based on the $C$ pool rather than the land use system (Figure 2.3-1).

$\mathrm{N}$-alkanes could not be detected in roots but otherwise clustered distinctly according to $\mathrm{C}$ pool. $\mathrm{N}$-alkanes in litter samples did not show a clustering based on land use, while n-alkane composition in oil palm plantation topsoils were dissimilar to n-alkanes in topsoils in forest and rubber plantations (Figure 2.3-1a). This emphasizes the importance of new C constituents in n-alkanes after land-use change, especially in soils of oil palm plantations. N-fatty acids did not cluster according to land use, but clustered moderately according to the analyzed C pools (Figure 2.3-1b). N-fatty acids in soils differed stronger from n-fatty acids in roots than from nfatty acids in litter. Especially the clustering of $n$-fatty acids in oil palm topsoil with forest and oil palm litter points to the importance of litter over roots as SOC source in oil palm plantations. Rubber and oil palm soil showed a small separation of hydroxy fatty acids from all litter and roots. The hydroxy fatty acids in forest topsoils however, cluster with forest litter and roots (Figure 2.3-1c). Pairwise comparison of Bray-Curtis dissimilarity of each fraction indicated that the variation between $C$ pools in the three different land-use systems was statistically significant with some overlap of the confidence intervals ( $R$ value $0.25-0.5$ ) between the substances based on the grouping $C$ pool and land use with a low difference of 
mean ranks ( $\mathrm{n}$-alkanes: $\mathrm{R}=0.4, p<0.05$; $\mathrm{n}$-fatty acids: $\mathrm{R}=0.4, p<0.05$; hydroxy fatty acids: $\mathrm{R}=0.3$, $p<0.05$; ANOSIM test for differences between litter and soil in forest, rubber and oil palm plantation). Alcohols/ketones were the only fraction, that did not show any clustering with respect to C pool or land use (Figure 2.3-1d). Alcohols/ketones in plantation topsoils overlapped with forest and rubber litter and oil palm roots but not with oil palm litter. Oil palm topsoil overlapped additionally with forest and rubber roots. Although plantations' topsoils overlayed with forest litter, plantations' topsoils did not overlap with forest topsoil. The forest soil, even, separated from its litter and roots. due to no clear clustering and an Rvalue close to zero (ANOSIM test: $\mathrm{R}=0.12, \mathrm{p}<0.05$ ) indicating rather similarities between the comparison groups than differences. Thus, we suppose alcohols/ketones is a fraction which does not seem to be suitable as biomarker to reconstruct $C$ origins after forest conversion to monocultures. This was confirmed by performing the indicator species analysis which found no substance significantly associated with any group of comparison. In contrast, indicator species analysis identified specific substances in n-alkanes, n-fatty acids and hydroxy fatty acids which were associated with one or a small group of $C$ pools in specific land use systems $(p<0.05)$.

Table 2.3-1: Indicator Substances identified by Indicator Species Analysis (Study 3). Denominations in brackets represent the single or the group of $C$ pool(s) or land-use type(s), which were separated from all other $C$ pools by the Indicator Species Analysis. No indicator substances were found in the alcohols/ketons fraction, which indicates that this fraction is not suitable for tracing $C$ sources.

\begin{tabular}{|c|c|c|c|}
\hline n-alkanes & n-fatty acids & hydroxy fatty and Di- acids & alcohols/ketones \\
\hline $\begin{array}{c}\mathrm{C}_{25} \\
\text { (oil palm soil) }\end{array}$ & $\begin{array}{c}\mathrm{i} 15: 0 \\
\text { (oil palm / rubber soil) }\end{array}$ & $\begin{array}{c}\text { 16-OH-16:0 } \\
\text { (oil palm / rubber soil) }\end{array}$ & -- \\
\hline \multirow[t]{5}{*}{$\begin{array}{c}\mathrm{C}_{31} \\
\text { (forest soil, rubber litter/soil) }\end{array}$} & $\begin{array}{c}18: 2 \omega 6,9 \\
\text { (Forest litter/roots, Oil palm } \\
\text { soil, Rubber litter/ roots) }\end{array}$ & $\begin{array}{l}\text { 2-OH-24:0 } \\
\text { (Oil Palm roots) }\end{array}$ & \\
\hline & $\begin{array}{c}24: 0 \\
\text { (Forest soil, Oil palm } \\
\text { litter/roots, Rubber soil) }\end{array}$ & $\begin{array}{l}\text { 16-Di-COOH-16:0 } \\
\text { (Forest soil, Oil palm soil, Rubber } \\
\text { soil) }\end{array}$ & \\
\hline & $\begin{array}{c}27: 0 \\
\text { (Forest soil, Oil palm soil, } \\
\text { Rubber soil) }\end{array}$ & & \\
\hline & $\begin{array}{c}28: 0 \\
\text { (Forest soil, Oil palm litter, } \\
\text { Rubber soil) }\end{array}$ & & \\
\hline & $\begin{array}{c}29: 0 \\
\text { (Forest soil, Oil palm litter/ } \\
\text { soil, Rubber soil) }\end{array}$ & & \\
\hline
\end{tabular}



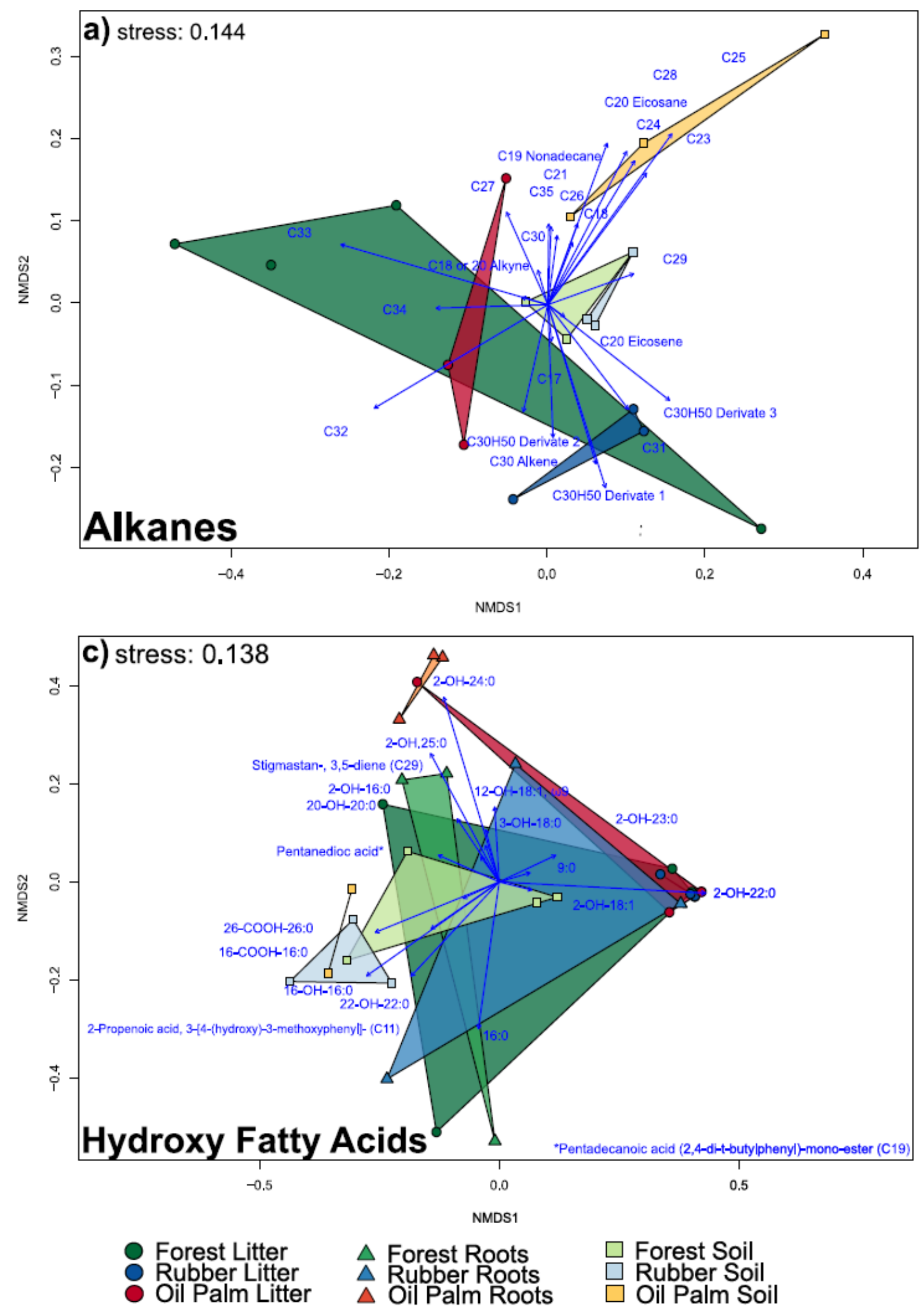

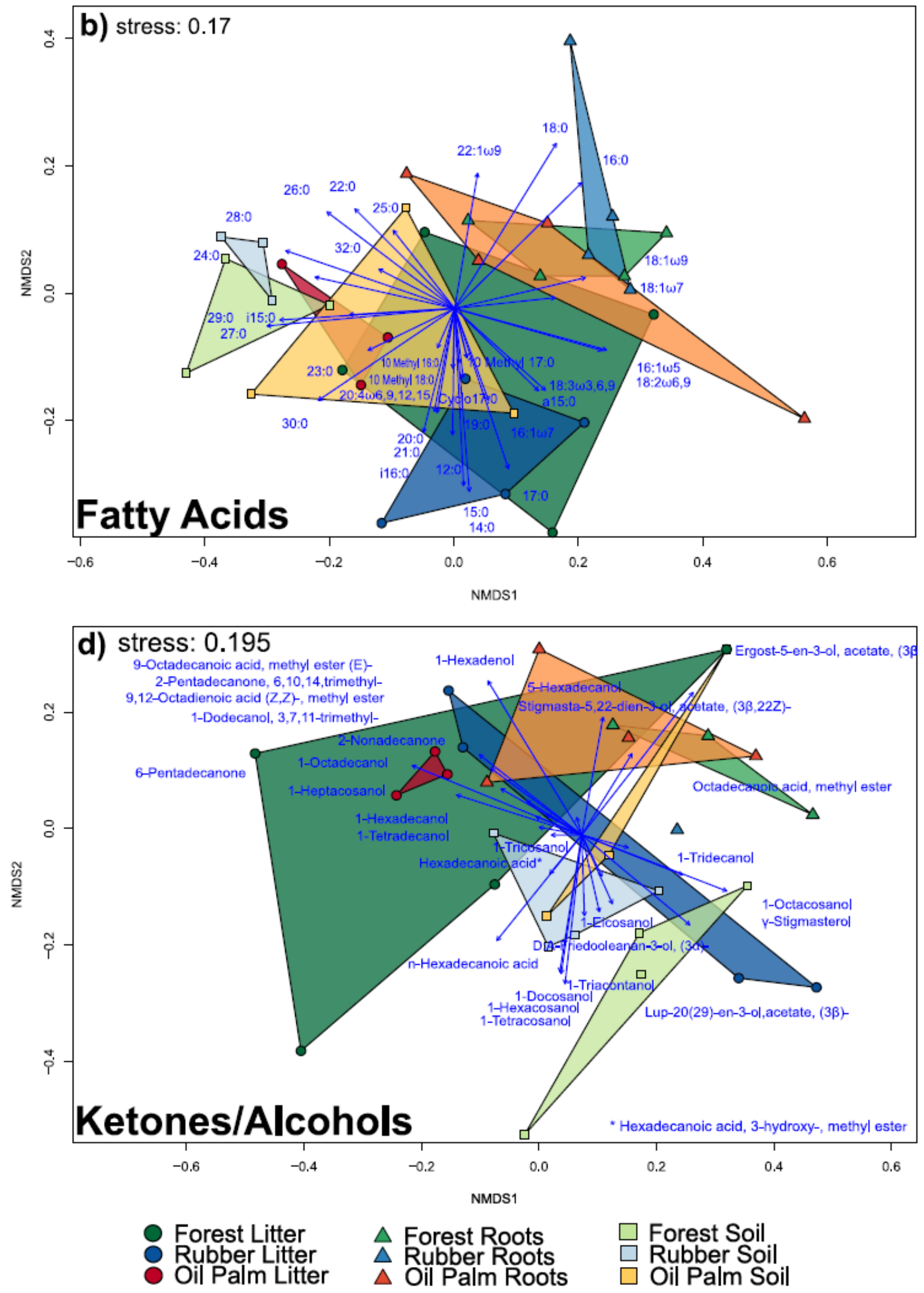

Figure 2.3-1: Non-metric multidimensional scaling of the entire (a) alkane, (b) fatty acid, (c) hydroxy fatty acid (d) ketones/alcohols dataset. The ordinations are based on Bray Curtis dissimilarity matrices. 


\subsubsection{Microbial Biomarker}

The fatty acid i15:0 is one of the biomarkers, identified as specific indicator, which was associated with topsoil from rubber and oil palm plantations (Figure 2.3-2). It was only present in topsoils of all three land-use types but could not be found in litter and root samples. However, it was more abundant in the managed ecosystems than under natural forest vegetation. Under rubber and oil palm plantations, it comprised an average of 2.5 to $3 \%$, respectively, of the total fatty acid abundance. The fact that i15:0 was not found in plant material at all, confirms the microbial origin in soils.

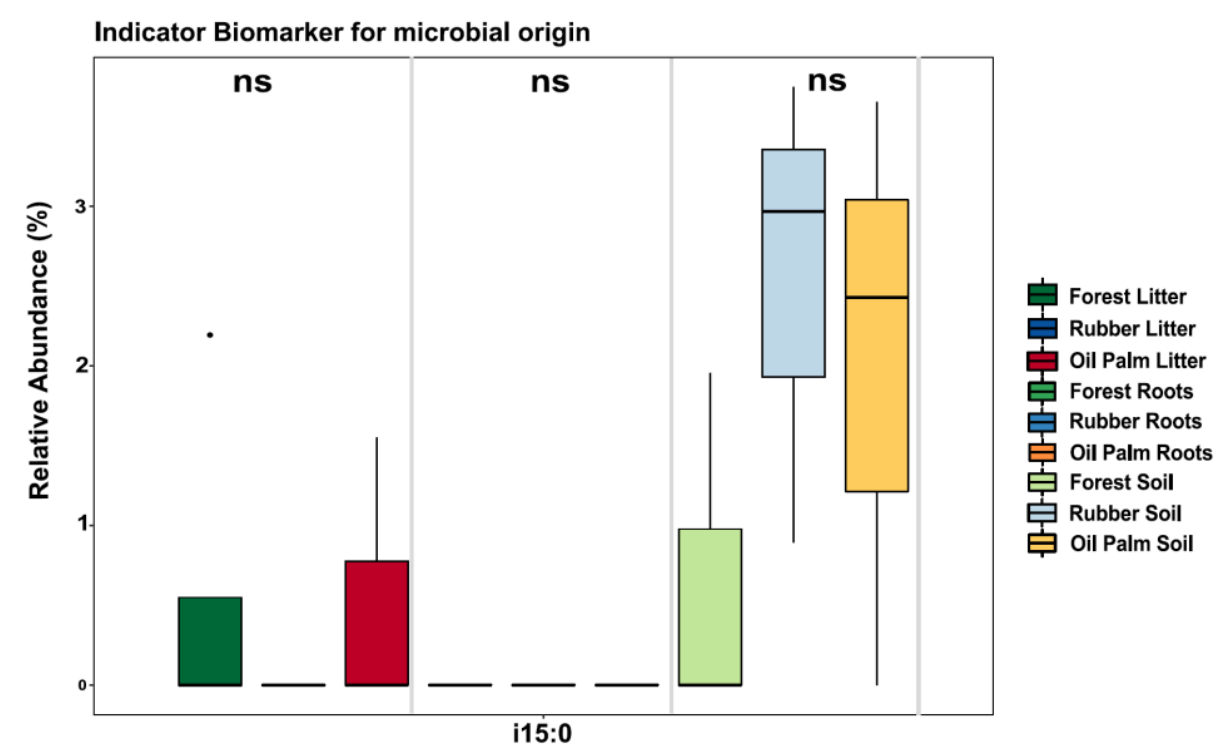

Figure 2.3-2: Microbial-derived biomarker. Boxplots show medians, interquartiles distances and extreme values, which are displayed as bold lines, boxes with whiskers and dots, respectively. Litter, roots and soil C pools are separated by grey lines. No significant difference (ns) could be found according to One-Way ANOVA $(p<0.05)$.

\subsubsection{Fungal and/or plant biomarker}

$18: 2 \omega 6,2$ occurs in the phospholipids of various eucaryotes and can thus consequently be of plant or microbial origin. Its appearance in litter and root as well as soil samples also suggests,

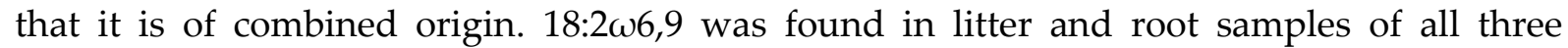
vegetation types as well as in the topsoils, but only of oil palm plantations (Figure 2.3-3). Litter and root samples had highest relative abundances; however, they were found with lower relative abundance in forest topsoil nor in rubber topsoil. In oil palm plantation topsoil, it constituted $3.38 \%( \pm 0.02)$ of the total fatty acid abundances, whereas it made up $8.3 \%( \pm 0.01)$ in forest roots. 


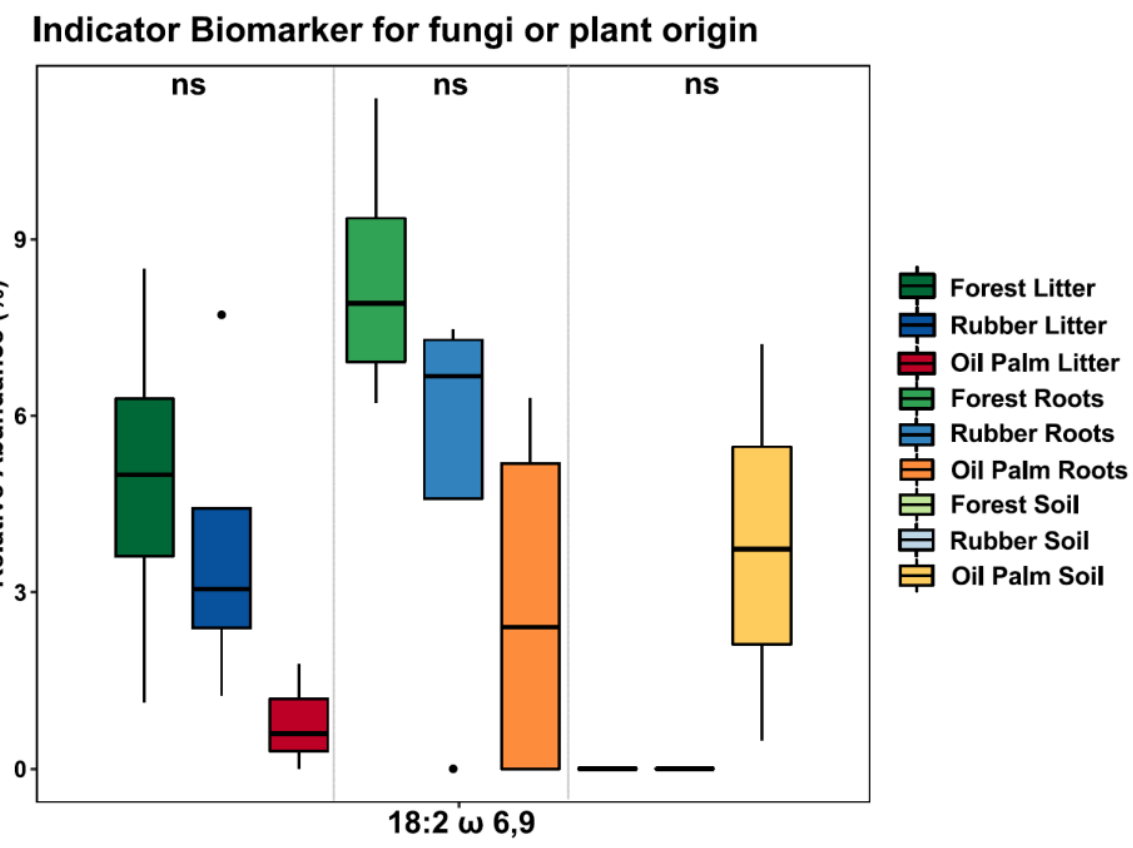

Figure 2.3-3: Indicator biomarker for fungi or plant origin. Boxplots show medians, interquartiles distances and extreme values, which are displayed as bold lines, boxes with whiskers and dots, respectively. Litter, roots and soil $C$ pools are separated by grey lines. No significant difference (ns) could be found according to One-Way ANOVA $(p<0.05)$.

\subsubsection{PLANT BIOMARKERS}

$\mathrm{N}$-alkanes were exclusively present in litter and soil samples. The n-alkane $\mathrm{C}_{25}$ was associated with oil palm soil and separated the topsoil under oil palm monoculture distinctly from topsoil in forest. $(\mathrm{p}<0.05)$. The relative abundance in oil palm topsoil was with $8.8 \% 2.3$-fold and 4 fold higher than in forest and rubber topsoil respectively, hinting at relatively lower decomposition than under natural vegetation and rubber cultivation (Figure 2.3-4 a). The nalkane $\mathrm{C}_{31}$ was 14-fold and 9-fold lower in forest litter than in rubber and oil palm litter, whereas between forest, rubber and oil palm soil, no significant differences in relative abundances of $C_{31}$ were found (Figure 2.3-4 b). 

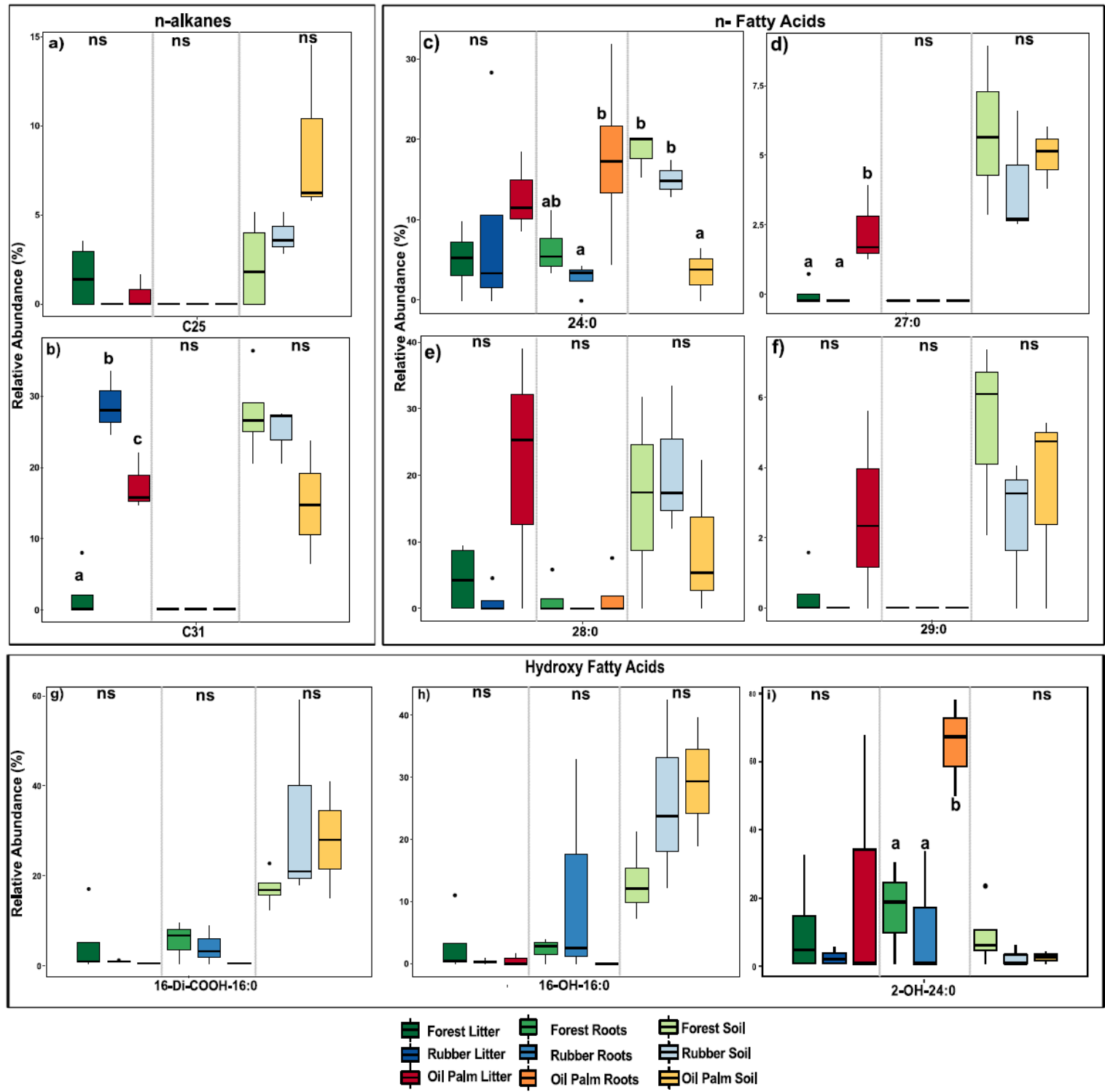

Figure 2.3-4: Plant-derived indicator biomarkers. Boxplots show medians, interquartiles distances and extreme values, which are displayed as bold lines, boxes with whiskers and dots, respectively. Litter, roots and soil C pools are separated by grey lines. Different letters indicate significant differences according to One-Way ANOVA with TukeyHSD post-hoc comparison $(p<0.05)$.

$\mathrm{N}$-alkanes in soils had a strong OEP between $\mathrm{C}_{27}$ and $\mathrm{C}_{33}$ in forest and rubber plantations; in oil palm plantations a clear OEP developed in the range from $\mathrm{C}_{30}-\mathrm{C}_{33}$ (Figure 2.3-5). Further, soils from all three land-use types revealed a strong dominance of $\mathrm{C}_{31}$ and $\mathrm{C}_{33}$. ACL of n-alkanes varied between $25.1( \pm 3.1)$ in oil palm soil and 30.2 $( \pm$ 0.4) C atoms in rubber soil. Litter ACLs ranged from $29.4( \pm 1.4)$ in oil palm and 30.9 ( \pm 0.8 and \pm 0.2 respectively) in forest and rubber plantations (Table 2.3-2). 
Table 2.3-2: Average chain lengths ( $A C L)$ of n-alkanes and $C_{16: 1+2}{ }^{*} C_{16: 0^{-1}}$ ratio of fatty acids. OEP data are presented as means $(n=4)$ with Standard Error of Means (SEM). Empty positions mean that no values for calculation were measured.

\begin{tabular}{lcc}
\hline \multicolumn{1}{c}{ C sources } & $\begin{array}{c}\text { n-alkanes: } \\
\text { ACL }\end{array}$ & $\begin{array}{c}\text { fatty acids: } \\
\mathrm{C}_{16: 1+2}{ }^{*} \mathrm{C}_{16: 0^{-1}}\end{array}$ \\
\hline Forest soil & $29.9 \pm 0.4$ & \\
Rubber soil & $30.2 \pm 0.4$ & 0.04 \\
Oil Palm Soil & $25.1 \pm 3.1$ & 0.23 \\
Forest litter & $30.9 \pm 0.8$ & 0.08 \\
Rubber litter & $30.9 \pm 0.2$ & 0.009 \\
Oil Palm litter & $29.4 \pm 1.4$ & 0.07 \\
Forest roots & - & 0.13 \\
Rubber Roots & - & 0.2 \\
\hline
\end{tabular}

Indicator n-fatty acids (24:0, 27:0,28:0 and 29:0) constituted a higher relative proportion in soil than in litter and root samples. However, low topsoil 24:0 relative abundance under oil palm emphasizes high loss of the input with 24:0 which is present in oil palm roots and litter with even higher relative abundance than in the other litter and roots (Figure 2.3-4 c). A similar result can be stated for 28:0, although 28:0 input through roots is very low (Figure 2.3-4 d). The two long-chain odd-numbered fatty acids 27:0 and 29:0 show the same pattern, i.e., they had a minor proportion in litter and roots except for oil palm, but were quite prominent (18 and $15 \%$ of fatty acids) in the soil of forest and rubber, respectively. Similar patterns were found in the fraction of the hydroxy fatty acids and di-acids. 16-OH-22:0 and 16-Di-COOH-16:0 which are suberin and therefore often considered as root associated (Pollard et al., 2008). Both substances were not be present in oil palm roots. In oil palm litter only 16-OH-16:0 was detected in a very small proportion. However, both substances were found in forest and rubber roots. Last substance found to be an indicator substance to separate oil palm roots from all other land-use types was 2-OH-24:0 (Figure 2.3-4 i). 2-OH-24:0 was higher in oil palm roots than in forest and rubber roots. With $\sim 65 \%$ of it represents the largest proportion of the total hydroxy fatty acid fraction. In topsoils all 2-OH-24:0 relative abundances were similar. The same pattern was found between litter 2-OH-24:0 relative abundances. 


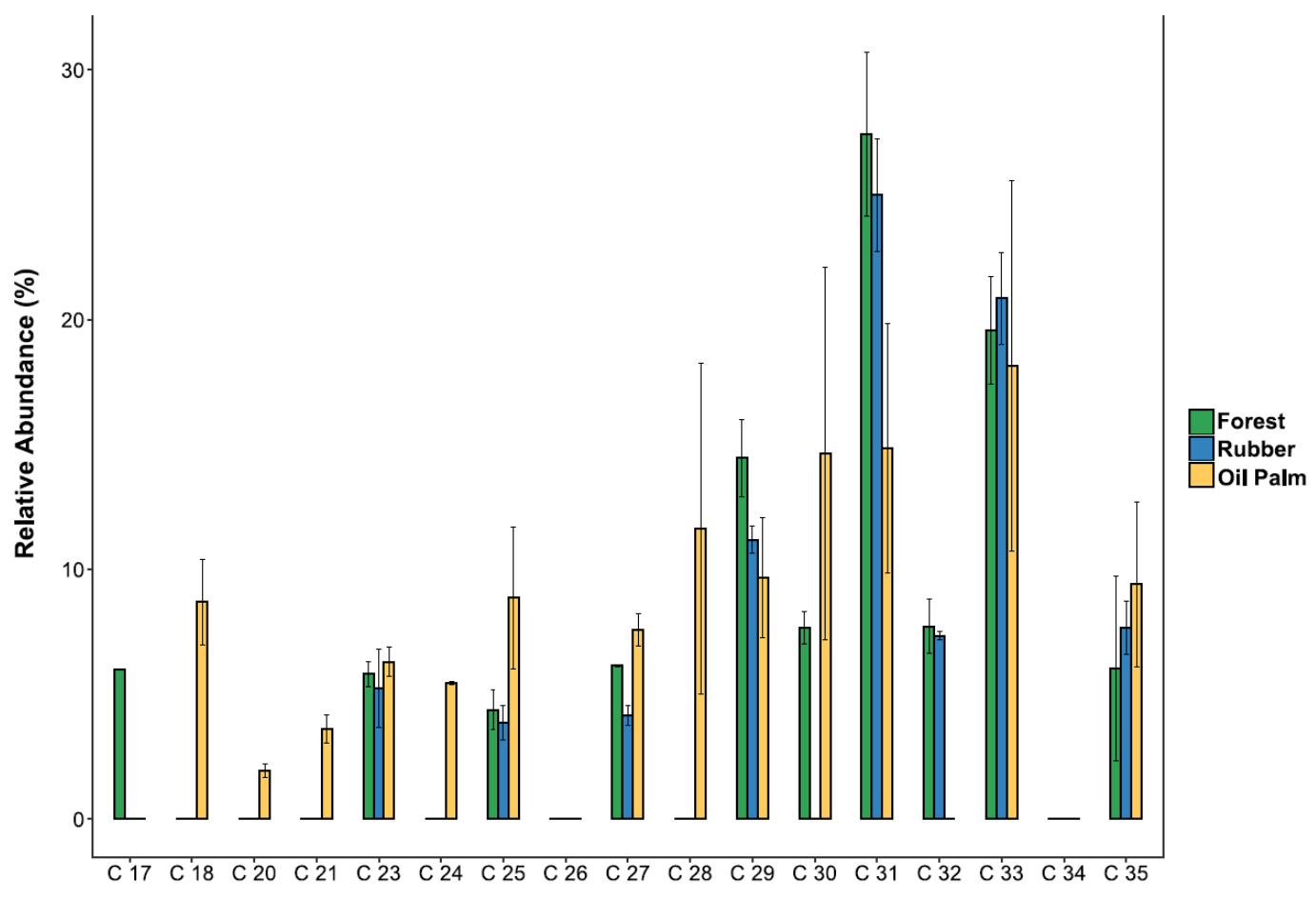

Figure 2.3-5: Mean n-alkane distribution patterns from soil in forest, rubber and oil palm plantations. Clear oddover-even-predominance (OEP) between $C_{27}$ and $C_{33} . C_{31}$ and $C_{33}$ dominance over $C_{27}$ and $C_{29}$. Values represented as means $(n=4)$. Error bars indicate the standard error of the mean. Newly identified $C_{30 H 50}$ Derivate 1 was excluded in this graph

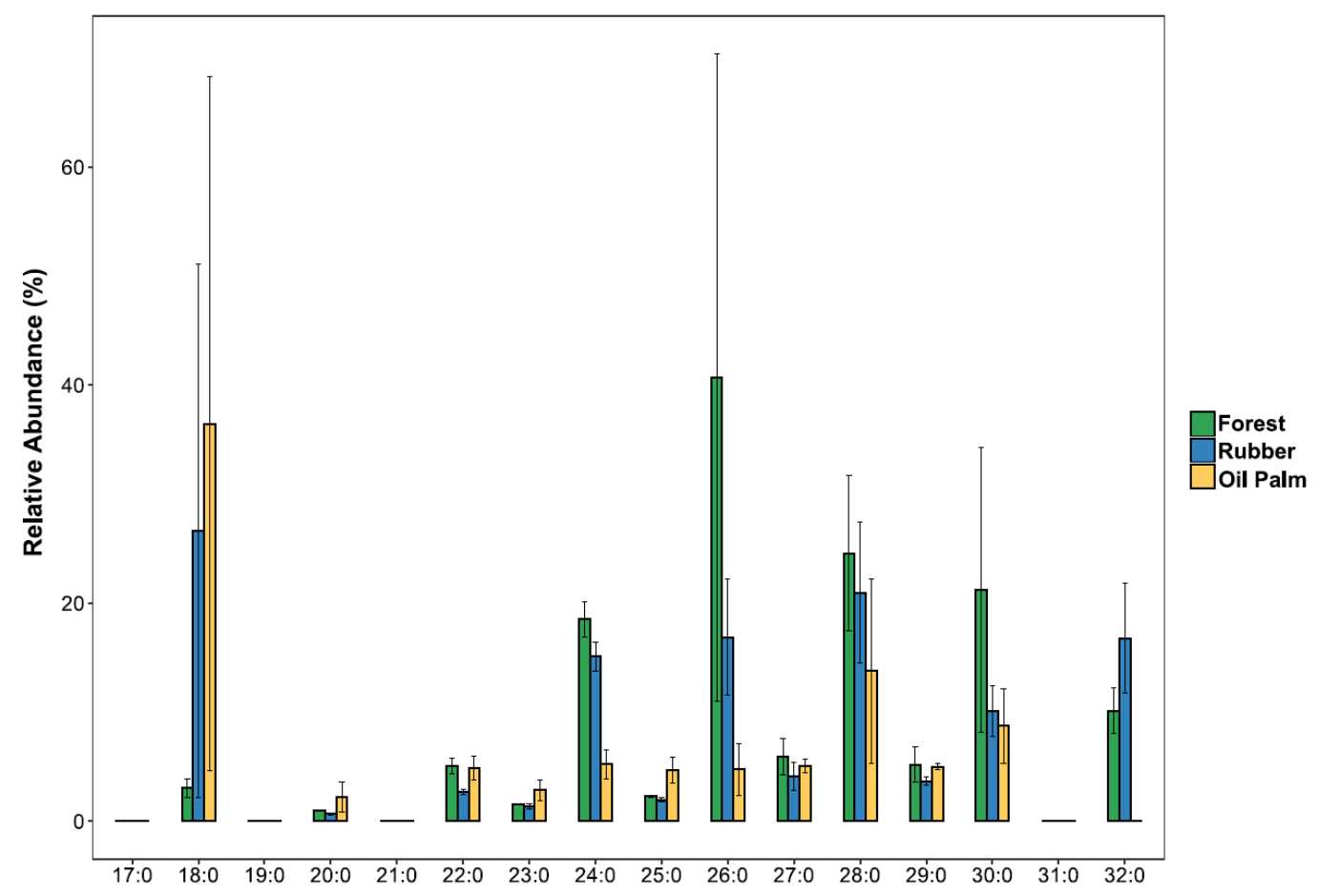

Figure 2.3-6: Mean n-fatty acid distribution from soil in forest, rubber and oil palm plantations. Clear evenover-odd predominance (EOP) between 22:0 and 32:0. Values are presented as means $(n=4)$. Error bars indicate the standard error of the mean. 


\subsubsection{DISCUSSION}

We aimed to identify sources of SOM constituents after land-use change and to determine the contribution of past vegetation to SOM to estimate changes in SOM composition. We were able to 1) identify indicator substances separating the individual land-use type and 2) could partially attribute them to their sources. Indicator substances were indicative for SOC origin and assigned for one of the three groups: microbial-derived (bacteria and/or-fungal-derived), fungal- and/or plant-derived and plant-derived substances. These findings verify our second hypothesis that past vegetation comprises a significant proportion of the present SOC and consequently forest vegetation-derived biomarker can still be found in the topsoils of both plantation types. Substances that have not been identified as indicator substances in our analysis are found to be non-specific and not suitable to differentiate between forest and plantation vegetation.

\subsubsection{Microbial- and plant-derived biomarkers}

i15:0 fatty acid is commonly known as a biomarker for gram-positive bacteria (Osipov and Turova, 1997; Ritchie et al., 2000), as confirmed by our results with high relative proportions in the topsoils but not in the litters (Figure 2.3-2).The low degradability, especially of grampositive necromass leads to its accumulation over time in the topsoil. Thus, it may in our case also be indicative for accumulation of microbial necromass (Ludwig et al., 2015). Microbial necromass was found to have a higher proportion for additional SOC formation under agricultural use with perennial grassland used for bioenergy, while the proportional increase of non-microbial necromass is smaller (Zhu et al., 2020a), which confirms our third hypothesis that after land-use change a relatively decrease in litter $C$ input leads to a relative increase in micobial biomass and consequently to microbial necromass contribution to SOM. Many other fatty acids of microbial communities co-occur in plants, especially those of fungis and gramnegative bacteria, since plants and gram-negative bacteria produce mono-unsaturated fatty acids. However, the terminal branching to iso- and anti-iso fatty acids is a rather unique feature of the gram-positive bacteria and the fatty acids, originating from phospholipids. If they are detected as free fatty acids, it will point towards the input of microbial necromass. This finding hints at another pathway of SOC formation, the so-called in-vivo microbial turnover pathway, which means that the turnover of organic substances occurred via cell uptake-biosynthesisgrowth and death results in the long-term deposition of microbial-derived C (Liang et al., 
2017). However, other fatty acids, potentially also of microbial (fungal) origin, are metabolized in soil much more rapidly such as 18:2w6,9 (Figure 2.3-3). Commonly it is used as fungal biomarker (e.g., Högberg, 2006; Kaiser et al., 2010), but also has been described as being available in plant tissues (Laczko et al., 2004; Zelles, 1997). Fatty acids with double bonds generally have a higher turnover than saturated fatty acids (Zhang et al., 2019) and therefore, 18:2 $\omega 6,9$ does not accumulate in forest and rubber topsoil. Its potential origin not only from fungi but also from plant membranes explains its high abundance in litter and root samples. In contrast, in oil palm plantation topsoil's it might be accumulated because we found similar

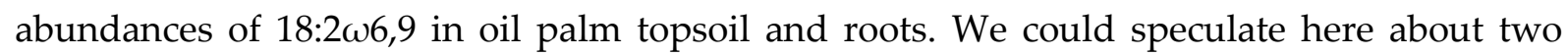
potential reasons: a) we observe here a shift in microbial community composition towards fungi as also found in upland plantations (Krashevska et al., 2018, 2015) or b) the microbial community in oil palm topsoils has a weaker capability to decompose lipid compounds. Other obstacles for the microbial community, hampering microbes to degrade 18:2 $\omega 6,9$ can be quality differences of forest, rubber and oil palm litter. It was found that element ratios $(C, N, P)$ as well as lignin concentrations changed with the change in litter type (from forest to plantations). With these changes a change in bacterial, fungal and testate amoebae composition occured, which negatively affected litter decomposition rates (Krashevska et al., 2018), which our data would confirm for oil palm but not for rubber plantations, because in rubber plantations decompistion processes seems to be unaffected compared to oil palm

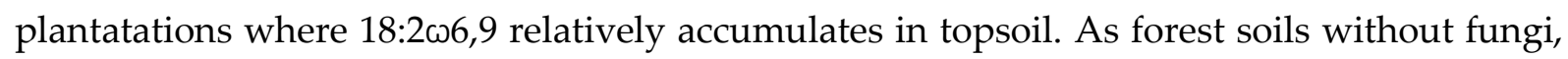
and thus dead fungal cells releasing 18:2w6,9, is highly unlikely, it must be said that the absence of 18:2w6,9 in forest soil can most likely only be attributed to the rapid decomposition

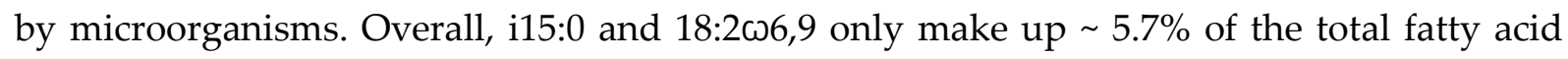
amount in oil palm and $2.8 \%$ in rubber topsoil, whereas clearly plant-derived substances (often with longer n-alkyl chains) have larger shares.

\subsubsection{Plant-derived biomarkers}

In all three land-use types, fatty acids with greatest abundance were the plant-derived fatty acids 24:0, 27:0 and 28:0 and 29:0. Relative abundance of 24:0 and 28:0 in oil palm litter is greater than in forest and rubber litter. We suppose that a continuous input is given by oil palm litter, because we found fatty acid 24:0 and 28:0 to make up $13 \%$ and $~ 23 \%$ respectively, of the total oil palm litter fatty acid fraction (Figure 2.3-4 c/e). If continuous input occurs, we 
suspect that high decomposition will occur too, because the content of this fatty acid in oil palm topsoil is much lower compared to the topsoil of forest and rubber. 24:0 in oil palm topsoil is strongly decreased compared to forest and rubber topsoils, but the pattern is vice versa (highest relative contents in oil palm) in litter and roots. This also indicates stronger decomposition of this plant-derived fatty acid in the topsoil of oil palm plantations than in rubber plantations' and forest topsoil. To prevent a complete depletion of 24:0 and 28:0 due to ongoing decomposition of these n-fatty acids, an ongoing replenishment by oil palm litter is necessary. Although it does not definitively rule this out, it argues against our interpretation in relation to $18: 2 \omega 6,9$, where we suggested a reduced ability of the microbial community to degrade fatty acids in oil palm plantations as a possible explanation. Thus, it rather supports the above explanation of a shift towards a more fungal-dominated community, which would also confirm the observed trends for the 28:0 fatty acid, since fungal communities are known to be experts in degrading long n-alkyl chains (Prenafeta-Boldú et al., 2019). Usually, longchain lipids are not considered to be part of soil-derived microbial biomass, but are attributed to plant origin (Harwood and Russel, 1984; Heinrich et al., 2015). Odd-chain fatty acids, however, are not classical compounds of plant litter or roots but rather the product of microbial transformation of even-chain plant-derived fatty acids (Dippold and Kuzyakov 2016). This holds true for the plant material of natural forests and rubber, which are low in 27:0 and 29:0 proportions, but not for oil palm litter, suggesting a higher input into soils in this system. Proportionally, 27:0 and 29:0 n-fatty acids' relative abundances to the total fatty-acid amount represent substantial constituents in the topsoils of all three land-use types, confirming the idea, that they are a product of microbial transformation in soils, leading to their accumulation. As both, 27:0 and 29:0, are long-chain n-fatty acids, they are more resistant than short-chain fatty acids to further microbial decomposition. For the long-chain n-alkanes $C_{25}$ and $C_{31}$ and at least for 27:0 and 29:0 n-fatty acids we need to consider that they were partly derived from leaf colonization by microbial biomass and/or fungi, since Nguyen Tu et al. (2011), showed litter contamination with long-chain alkanes by microbial residues and generalized this finding for other long-chain fatty lipids. This assumption of litter colonization by microbial lipids is further supported by high $C_{16: 1+2}{ }^{*} \mathrm{C}_{16: 0-1}$ ratios (> 0.1) in root samples (Table 2.3-2), which indicate the contribution of microbial-derived compounds to the total fatty acid content due to the common presence of $\mathrm{C}_{16: 1+2}$ fatty acids in microbial tissue. A strong argument for plant origin and against microbial transformation of n-alkanes however is that soil samples have a 
clear odd-over-even-predominance (OEP) in the range of $\mathrm{C}_{27}-\mathrm{C}_{31}$ (Figure 2.3-6) and long ACLs (Table 2.3-2), whereas n-alkanes produced by many bacteria show a distribution pattern ranging from $\mathrm{C}_{11}$ to $\mathrm{C}_{35}$ without any OEP and are characterized by shorter ACLs (Bush and McInerney, 2013; Ladygina et al., 2006). N-fatty acids have a clear EOP (Figure 2.3-6) pattern, confirming this interpretation (Kollattukudy, 1980). N-alkanes pattern in soils in all three landuse types revealed a strong dominance of $C_{31}$ and $C_{33}$ over $C_{27}$ and $C_{29}$, associated with grass and herb origin. Given that a $C_{31}$ and $C_{33}$ characterizes grass and herbs as $C$ sources (Zech et al., 2012), we assume that the litter-based C input into soils in all three land-use types is dominated by herbs and grass over trees and shrubs. Since there is a dense herb layer in tropical forests covering the soil, we consider higher $C_{31}$ and $C_{33}$ than $C_{27}$ and $C_{29}$ concentrations to be comprehensible. The same holds true for rubber plantations, that are often covered with grass. Oil palm plantations however often have bare soil and sometimes a fragmented grass vegetation. This is probably reflected by a less pronounced dominance of $C_{31}$ and $C_{33}$ compared to $\mathrm{C}_{27}$ and $\mathrm{C}_{29}$ (Figure 2.3-5).

16-OH-22:0 and 16-Di-COOH-16:0 are hydroxy fatty acids which are suberin and therefore root associated (Pollard et al., 2008). Their relatively high contents in the topsoils of all three land-use types compared to their contents in the source material (litter and roots) suggests, that they accumulate in soils most likely because they did not get decomposed. Although oil palm topsoil had the highest relative abundance of 16-OH-16:0 and 16-Di-COOH-16:0, no input by oil palm litter or roots could be stated, because 16-Di-COOH-16:0 could not be detected at all and 16-OH-16:0 had very low abundances (Figure 2.3-4 g/h). We consequently assume that 16-OH-16:0 and 16-Di-COOH-16:0 in oil palm topsoils still originate from forest sources, especially because they are also present in forest soil. This meets the requirement for a forest biomarker, that the substances should be present in forest litter or/and roots and soil, but not be present in the new organic matter input into the plantation soils. Since 16-OH-16:0 make up $\sim 29 \%$ and 16-Di-COOH-16:0 comprise $~ 28 \%$ of the total OHFA fraction of oil palm topsoils, this biomarker accounts for a significant share as SOM source in forests. The relatively higher proportion of this most likely suberin-derived lipid suggests, that many easier-todecompose lipids got already degraded leading to an enrichment of this more recalcitrant compound in the strongly degraded SOM of the oil palm plantations (Krull et al., 2003; Lorenz et al., 2007). Unfortunately, we cannot use the same approach to prove suberin accumulation 
and SOM degradation in the rubber plantations, because we found a substantial amount of 16Di-COOH-16:0 in the rubber roots, excluding a contribution of forest as only possible source.

To further study our first hypothesis, we searched for substances not present in past vegetation but found in one or more of the $\mathrm{C}$ sources feeding plantations' SOM and thus indicating recent C input sources. We identified 2-OH-24:0 as a specific biomarker representative for oil palm. It appears in all land-use types and all C sources, but in oil palm roots it has a particularly high proportion. 2-OH-24:0 (cerebronic acid) is a long-chain hydroxy fatty acid composed of the nfatty acid 24:0 (tetracosanoic or lignoceric acid) having a 2-hydroxy substituent. Lignoceric acid is no substance exclusively associated with oil palm, it is a constituent of most natural waxes and a byproduct of lignin production (Moore et al., 2020). This is the reason why it is present in plants from other land-use types as well, however it is particularly prominent in oil palm as a $\mathrm{C}$ source. Because of a significantly lower share in soil, we assume a rapid degradation after incorporation into topsoil suggesting that oil palm root residues might not be preferably stabilized in the soils of oil palm plantations. A combined view on n-alkane, nfatty acid and hydroxy fatty acid biomarkers indicates that there is a complex system of pathways of C incorporation into soil. Single biomarkers such as i15:0 indicate microbial residues as an important source of $\mathrm{C}$, whereas long-chain lipids, e.g., $\mathrm{n}$-alkanes and $\mathrm{n}$-fatty acids, distinctly showed the importance of plant-derived $C$ input into soil. Especially in combination with molecular proxies, we assume that as $C$ sources plants may play a substantial role within the total SOM, but microbial necromass accumulates with ongoing SOC degradation under plantation management. Alcohols and ketones did not seem to be a powerful group of biomarkers, because no substance separated based on the indicator species analysis the specific $C$ sources or land-use types.

\subsubsection{CONCLUSIONS}

Plant-derived C is one of the major sources for SOC. Here, we identified pathways of C input into soil after forest conversion to rubber and oil palm plantations by reconstructing SOM dynamic following conversion to plantations. N-alkane, long-chain fatty acid and hydroxy fatty acid biomarkers revealed that $C$ input from past forest vegetation still contributes to the plantations' SOC pool. Main pathways of SOC formation are via microbial biomass as

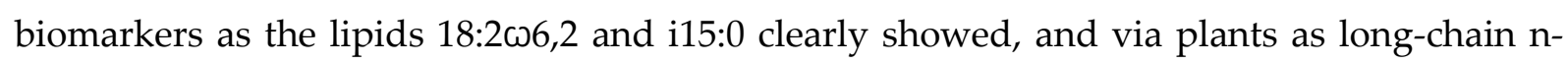
alkanes and fatty acids revealed. However, a partially microbial overprint due to microbial 
colonization of litter was found indicated by odd-chain fatty acids e.g., 27:0 and 29:0. For this, additional indicators e.g., a strong OEP and high ACLs point at a high proportion of organic matter with molecular features of plant material. We identified one biomarker (2-OH-24:0) to be very promising as an oil palm specific biomarker in contrast to rubber and forest vegetation, implying to be able to trace with this marker molecule the recent $C$ source for the SOC pool under agricultural use after forest conversion. Furthermore, we identified suberin-derived 16$\mathrm{OH}-16: 0$ and 16-Di-COOH-16:0 as marker molecules for the former forest' SOM contribution to recent oil palm SOM. An accumulation of these markers over the relative contents of forest soils themselves points towards the strong degradation of easily available and non-recalcitrant organic matter fractions. This underlines previous studies conclusions on the threat of especially oil palm plantation management of the high SOC stocks. Besides absolute amounts this study demonstrates that the molecular composition of SOM dramatically changes by conversion to plantations with yet unknown implications for ecosystem functions of the SOM, stability of this $\mathrm{C}$ pool and the potential for restauration of these soils in case of the decision to abandon land use in these areas.

\section{ACKNOWLEDGEMENTS}

This study was funded by the German Research Foundation (DFG) project number 192626868 - SFB 990 in the framework of the collaborative German-Indonesian research project CRC 990. This study was conducted using samples collected based on the Collection permit No. 207/SIP/FRP/E5/Dit.KI/VII/2016 recommended by the Indonesian Institute of Science (LIPI) and issued by the Ministry of Forestry (PHKA). The CRC 990 selected the study sites. We thank PT. Restorasi Ekosistem Indonesia for the possibility to work in the Hutan Harapan as well as local plot owners granting us access to their properties. We would like to thank Winda Januarista and Ardian for their support during field work and Dr. Callum Banfield for his help during laboratory work. 


\section{REFERENCES}

Angst, G., John, S., Mueller, C.W., Kögel-Knabner, I., Rethemeyer, J., 2016. Tracing the sources and spatial distribution of organic carbon in subsoils using a multi-biomarker approach. Sci. Rep. 6, 112. https://doi.org/10.1038/srep29478

Austin, K.G., Schwantes, A., Gu, Y., Kasibhatla, P.S., 2019. What causes deforestation in Indonesia? Environ. Res. Lett. 14, 24007. https://doi.org/10.1088/1748-9326/aaf6db

Birk, J.J., Dippold, M., Wiesenberg, G.L.B., Glaser, B., 2012. Combined quantification of faecal sterols, stanols, stanones and bile acids in soils and terrestrial sediments by gas chromatography-mass spectrometry. J. Chromatogr. A 1242, 1-10. https://doi.org/10.1016/j.chroma.2012.04.027

Blagodatsky, S.A., Richter, O., 1998. Microbial growth in soil and nitrogen turnover: A theoretical model considering the activity state of microorganisms. Soil Biol. Biochem. 30, 1743-1755. https://doi.org/10.1016/S0038-0717(98)00028-5

Bollag, J.M., Stotzky, G., 2017. Soil biochemistry, in: Bollag, J.-M.; Stotzky, G. (Ed.), Soil Biochemistry. Dekker, New York City, NY, pp. 1-565. https://doi.org/10.1201/9780203739389

Borchard, N., Bulusu, M., Meyer, N., Rodionov, A., Herawati, H., Blagodatsky, S., Cadisch, G., Welp, G., Amelung, W., Martius, C., 2019. Deep soil carbon storage in tree-dominated land use systems in tropical lowlands of Kalimantan. Geoderma 354, 113864. https://doi.org/10.1016/j.geoderma.2019.07.022

Bush, R.T., McInerney, F.A., 2013. Leaf wax n-alkane distributions in and across modern plants: Implications for paleoecology and chemotaxonomy. Geochim. Cosmochim. Acta 117, 161-179. https://doi.org/10.1016/j.gca.2013.04.016

Chen, L., Li, F., Liu, J., He, X., 2021. Multiple lipid biomarkers record organic matter sources and paleoenvironmental changes in the East China Sea coast over the past 160 years. Holocene 31, 1627. https://doi.org/10.1177/0959683620961500

Collister, J.W., Rieley, G., Stern, B., Eglinton, G., Fry, B., 1994. Compound-specific $\delta{ }^{13} \mathrm{C}$ analyses of leaf lipids from plants with differing carbon dioxide metabolisms. Org. Geochem. 21, 619-627. https://doi.org/10.1016/0146-6380(94)90008-6

de Blécourt, M., Brumme, R., Xu, J., Corre, M.D., Veldkamp, E., 2013. Soil Carbon Stocks Decrease following Conversion of Secondary Forests to Rubber (Hevea brasiliensis) Plantations. PLoS One 8. https://doi.org/10.1371/journal.pone.0069357

De Cáceres, M., Legendre, P., 2009. Associations between species and groups of sites: Indices and statistical inference. Ecology 90, 3566-3574. https://doi.org/10.1890/08-1823.1

Drescher J, Rembold K, Allen K, Beckschäfer P, Buchori D, Clough Y, Faust H, Fauzi AM, Gunawan D, Hertel D, Irawan B, Jaya INS, Klarner B, Kleinn C, Knohl A, Kotowska MM, Krashevska V, Krishna V, Leuschner C, Lorenz W, Meijide A, Melati D, Nomura M, Pérez, K.H. and S.S., 2016. Ecological and socio-economic functions across tropical land use systems after rainforest conversion. Philos. Trans. R. Soc. B Biol. Sci. 371, 20150275. https://doi.org/10.1098/rstb.2015.0275

Eglinton, G., Hamilton, R.J., 1967. Leaf epicuticular waxes. Science (80-. ). 156, 1322-1335. https://doi.org/10.1126/science.156.3780.1322

Eglinton, T.I., Eglinton, G., 2008. Molecular proxies for paleoclimatology. Earth Planet. Sci. Lett. 275, 116. https://doi.org/10.1016/j.epsl.2008.07.012

Fox, J. and Weisberg, S., 2011. An $\{\mathrm{R}\}$ Companion to Applied Regression, Third Edition. Thousands Oaks CA:Sage. https://doi.org/https://socialsciences.mcmaster.ca/jfox/Books/Companion/

Gibbs, H.K., Ruesch, A.S., Achard, F., Clayton, M.K., Holmgren, P., Ramankutty, N., Foley, J.A., 2010. Tropical forests were the primary sources of new agricultural land in the 1980s and 1990s 107, 16. https://doi.org/10.1073/pnas.0910275107

Graves, Spencer; Piepho, Hans-Peter; Selzer, L. with the help from S.D.-Ra., 2019. multcompView: Visualizations of Paired Comparisons R package.

Guillaume, T., Damris, M., Kuzyakov, Y., 2015. Losses of soil carbon by converting tropical forest to plantations: Erosion and decomposition estimated by $\delta^{13} \mathrm{C}$. Glob. Chang. Biol. 21, 3548-3560. https://doi.org/10.1111/gcb.12907

Guillaume, T., Holtkamp, A.M., Damris, M., Brümmer, B., Kuzyakov, Y., 2016. Soil degradation in oil 
palm and rubber plantations under land resource scarcity. Agric. Ecosyst. Environ. 232, 110-118. https://doi.org/10.1016/j.agee.2016.07.002

Harwood, J.L.; Russel, N.J., 1984. Distribution of lipids, in: Lipids in Plants and Microbes. Springer, Dordrecht, pp. 35-70.

Heinrich, S., Dippold, M.A., Werner, C., Wiesenberg, G.L.B., Kuzyakov, Y., Glaser, B., 2015. Allocation of freshly assimilated carbon into primary and secondary metabolites after in situ 13C pulse labelling of Norway spruce (Picea abies). Tree Physiol. 35, 1176-1191. https://doi.org/10.1093/treephys/tpv083

Hennings, N., Becker, J.N., Guillaume, T., Damris, M., Dippold, M.A., Kuzyakov, Y., 2021. Riparian wetland properties counter the effect of land-use change on soil carbon stocks after rainforest conversion to plantations. Catena 196, 104941. https://doi.org/10.1016/j.catena.2020.104941

Kögel-Knabner, I., 2002. The macromolecular organic composition of plant and microbial residues as inputs to soil organic matter: Fourteen years on. Soil Biol. Biochem. 105, A3-A8. https://doi.org/10.1016/j.soilbio.2016.08.011

Kolattukudy, P.E., Croteau, R., Buckner, J.S., 1976. Biochemistry of plant waxes, in: Kolattukudy, P.. (Ed.), Chemistry and Biochemistry of Natural Waxes. Elsevier, Amsterdam, pp. 290-348.

Kollattukudy, P.E., 1980. Cutin, Suberin, and Waxes, in: Lipids: Structure and Function. pp. 571-645. https://doi.org/10.1016/b978-0-12-675404-9.50024-2

Krull, E.S., Baldock, J.A., Skjemstad, J.O., 2003. Importance of mechanisms and processes of the stabilisation of soil organic matter for modelling carbon turnover. Funct. Plant Biol. 30, 207-222. https://doi.org/10.1071/FP02085

Ladygina, N., Dedyukhina, E.G., Vainshtein, M.B., 2006. A review on microbial synthesis of hydrocarbons. Process Biochem. 41, 1001-1014. https://doi.org/10.1016/j.procbio.2005.12.007

Laumonier, Y., 1997. The Vegetation and Physiography of Sumatra. Springer Netherlands, Dordrecht. https://doi.org/10.1007/978-94-009-0031-8_1

Lenth, R. V., 2016. Least-Squares Means: The R Package lsmeansNo Title. J. Stat. Softw. 69, 1-33. https://doi.org/doi:10.18637/jss.v069.i01

Lorenz, K., Lal, R., Preston, C.M., Nierop, K.G.J., 2007. Strengthening the soil organic carbon pool by increasing contributions from recalcitrant aliphatic bio(macro)molecules. Geoderma 142, 1-10. https://doi.org/10.1016/j.geoderma.2007.07.013

Ludwig, M., Achtenhagen, J., Miltner, A., Eckhardt, K.U., Leinweber, P., Emmerling, C., Thiele-Bruhn, S., 2015. Microbial contribution to SOM quantity and quality in density fractions of temperate arable soils. Soil Biol. Biochem. 81, 311-322. https://doi.org/10.1016/j.soilbio.2014.12.002

Margono, B.A., Potapov, P. V, Turubanova, S., Stolle, F., Hansen, M.C., 2014. Primary forest cover loss in indonesia over 2000-2012. Nat. Clim. Chang. https://doi.org/10.1038/nclimate2277

Merten, J., Nielsen, J.Ø., Rosyani, Soetarto, E., Faust, H., 2021. From rising water to floods: Disentangling the production of flooding as a hazard in Sumatra, Indonesia. Geoforum 118, 56-65. https://doi.org/10.1016/j.geoforum.2020.11.005

Merten, J., Stiegler, C., Hennings, N., Purnama, E.S., Röll, A., Agusta, H., Dippold, M.A., Fehrmann, L., Gunawan, D., Hölscher, D., Knohl, A., Kückes, J., Otten, F., Zemp, D.C., Faust, H., 2020. Flooding and land use change in Jambi Province, Sumatra: Integrating local knowledge and scientific inquiry. Ecol. Soc. 25, 1-29. https://doi.org/10.5751/ES-11678-250314

Moore, E.M., Wagner, C., Komarnytsky, S., 2020. The Enigma of Bioactivity and Toxicity of Botanical Oils for Skin Care. Front. Pharmacol. 11, 1-17. https://doi.org/10.3389/fphar.2020.00785

Nguyen Tu, T.T., Egasse, C., Zeller, B., Bardoux, G., Biron, P., Ponge, J.F., David, B., Derenne, S., 2011. Early degradation of plant alkanes in soils: A litterbag experiment using 13C-labelled leaves. Soil Biol. Biochem. 43, 2222-2228. https://doi.org/10.1016/j.soilbio.2011.07.009

Oksanen, J., Blanchet, F.G., Kindt, R., Legen-, P., Minchin, P.R., Hara, R.B.O., Simpson, G.L., Solymos, P., Stevens, M.H.H., Szoecs, E., Wagner, H., 2019. vegan: Community Ecology Package. R Packag. version 2.5-6.

Osipov, G.A., Turova, E.S., 1997. Studying species composition of microbial communities with the use of gas chromatography-mass spectrometry: Microbial community of kaolin. FEMS Microbiol. Rev. 
20, 437-446. https://doi.org/10.1016/S0168-6445(97)00048-X

Otto, A., Simpson, M.J., 2005. Degradation and preservation of vascular plant-derived biomarkers in grassland and forest soils from Western Canada. Biogeochemistry 74, 377-409. https://doi.org/10.1007/s10533-004-5834-8

P.A. Meyers, 2003. Application of organic geochemistry to paleolimnological reconstruction: a summary of examples from the Laurention Great Lakes. Org. Geochem. 34, 261-289.

Pollard, M., Beisson, F., Li, Y., Ohlrogge, J.B., 2008. Building lipid barriers: biosynthesis of cutin and suberin. Trends Plant Sci. 13, 236-246. https://doi.org/10.1016/j.tplants.2008.03.003

Prenafeta-Boldú, F.X., de Hoog, G.S., Summerbell, R.C., 2019. Fungal Communities in Hydrocarbon Degradation, in: McGenity, T.J. (Ed.), Microbial Communities Utilizing Hydrocarbons and Lipids: Members, Metagenomics and Ecophysiology. Springer Nature Switzerland AG, pp. 1-36. https://doi.org/10.1007/978-3-319-60063-5_8-2

R Core Team, 2018. R: A language and environment for statistical computing. R Foundation for Statistical Computing, Vienna, Austria. https://doi.org/https://www.R-project.org/

Rembold, K., Mangopo, H., Tjitrosoedirdjo, S.S., Kreft, H., 2017. Plant diversity, forest dependency, and alien plant invasions in tropical agricultural landscapes. Biol. Conserv. 213, 234-242. https://doi.org/10.1016/j.biocon.2017.07.020

Ritchie, N.J., Schutter, M.E., Dick, R.P., Myrold, D.D., 2000. Use of length heterogeneity PCR and fatty acid methyl ester profiles to characterize microbial communities in soil. Appl. Environ. Microbiol. 66, 1668-1675. https://doi.org/10.1128/AEM.66.4.1668-1675.2000

Sahner, J., Budi, S.W., Barus, H., Edy, N., Meyer, M., Corre, M.D., Polle, A., 2015. Degradation of root community traits as indicator for transformation of tropical lowland rain forests into oil palm and rubber plantations. PLoS One 10, 1-19. https://doi.org/10.1371/journal.pone.0138077

Smith, D.R., Townsend, T.J., Choy, A.W.K., Hardy, I.C.W., Sjögersten, S., 2012. Short-term soil carbon sink potential of oil palm plantations. GCB Bioenergy 4, 588-596. https://doi.org/10.1111/j.17571707.2012.01168.x

Song, X.P., Hansen, M.C., Stehman, S. V., Potapov, P. V., Tyukavina, A., Vermote, E.F., Townshend, J.R., 2018. Global land change from 1982 to 2016. Nature 560, 639-643. https://doi.org/10.1038/s41586018-0411-9

Wickham, H.; Romain, F.; Henry, L.; Müller, K., 2020. dplyr: A Grammar of Data Manipulation. R Packag. version 0.8.5.

Wickham, H., 2007. Reshaping Data with the reshape Package. J. Stat. Softw. 21, 1-20.

Wiesenberg, G.L.B., Dorodnikov, M., Kuzyakov, Y., 2010. Source determination of lipids in bulk soil and soil density fractions after four years of wheat cropping. Geoderma 156, 267-277. https://doi.org/10.1016/j.geoderma.2010.02.026

Wiesenberg, G.L.B., Schwark, L., Schmidt, M.W.I., 2004. Improved automated extraction and separation procedure for soil lipid analyses. Eur. J. Soil Sci. 55, 349-356. https://doi.org/10.1111/j.13510754.2004.00601.x

Zech, M., Buggle, B., Leiber, K., Marković, S., Glaser, B., Hambach, U., Huwe, B., Stevens, T., Sümegi, P., Wiesenberg, G., Zöller, L., 2010. Reconstructing Quaternary vegetation history in the Carpathian Basin, SE-Europe, using n-alkane biomarkers as molecular fossils: Problems and possible solutions, potential and limitations. E\&amp;G Quat. Sci. J. 58, 148-155. https://doi.org/10.3285/eg.58.2.03

Zech, M., Buggle, B., Leiber, K., Marković, S., Glaser, B., Hambach, U., Huwe, B., Stevens, T., Sümegi, P., Wiesenberg, G., Zöller, L., 2009. Reconstructing Quaternary vegetation history in the Carpathian Basin, SE-Europe, using n-alkane biomarkers as molecular fossils: Problems and possible solutions, potential and limitations. E\&amp;G Quat. Sci. J. 58, 148-155. https://doi.org/10.3285/eg.58.2.03

Zech, M., Rass, S., Buggle, B., Löscher, M., Zöller, L., 2012. Reconstruction of the late Quaternary paleoenvironments of the Nussloch loess paleosol sequence, Germany, using n-alkane biomarkers. Quat. Res. (United States) 78, 226-235. https://doi.org/10.1016/j.yqres.2012.05.006

Zhang, Y., Zheng, N., Wang, J., Yao, H., Qiu, Q., Chapman, S.J., 2019. High turnover rate of free 
phospholipids in soil confirms the classic hypothesis of PLFA methodology. Soil Biol. Biochem. 135, 323-330. https://doi.org/10.1016/j.soilbio.2019.05.023

Zhu, X., Jackson, R.D., DeLucia, E.H., Tiedje, J.M., Liang, C., 2020. The soil microbial carbon pump: From conceptual insights to empirical assessments. Glob. Chang. Biol. 26, 6032-6039. https://doi.org/10.1111/gcb.15319 


\subsection{Management extensification in oil palm plantations reduces SOC decomposition}

Nina Hennings ${ }^{1 *}$, Katharina M. Fricke ${ }^{1}$, Muhammad Damris ${ }^{3}$, Michaela A. Dippold ${ }^{1}$, Yakov Kuzyakov $^{2}$

submitted to: Soil Biology and Biochemistry, under review since:

${ }^{1}$ Biogeochemistry of Agroecosystems, Georg-August-Universität Göttingen

${ }^{2}$ Soil Science of Temperate Ecosystems, Georg-August-Universität Göttingen

${ }^{3}$ Faculty of Science and Technology, University of Jambi, Indonesia

${ }^{*}$ Corresponding author: Nina Hennings, Soil Science of Temperate Ecosystems, University of Göttingen, Büsgenweg 2, 37077 Göttingen, Germany. E-mail: nina.hennings@forst.unigoettingen.de, Telephone: +49 (0) 5513912294 


\subsubsection{ABSTRACT}

Large scale oil palm monocultures are continuously replacing Indonesia's tropical rainforests. The impact of intensive nitrogen $(\mathrm{N})$ fertilization and herbicide application on biogeochemical processes in these monocultures remains unknown. Thus, we aim to understand NPK and herbicide effects on soil carbon (C) cycle. We hypothesize that (1) increased microbial activity due to $\mathrm{N}$ fertilization leads to faster soil organic matter (SOM) decomposition and to increased $\mathrm{CO}_{2}$ emissions from soil. Despite this, we expect (2) that herbicide application increases soil organic carbon (SOC) sequestration, as it counteracts the fertilizer's effects by hampering soil microbial activity, by deactivating the same synthesizing pathway as in plants, leading to decreased microbial respiration. We investigated the effects of fertilization (conventional and reduced NPK) and weed control (herbicide or mechanical weeding) on SOC decomposition in the rows between the palms (interrows) and around the palm stems (weeding circles). ${ }^{14} \mathrm{C}$ labelled glucose was added to soil to analyze the response of microbial activity and SOC mineralization during 30-day incubation. Conventional fertilization caused microbial activation and destabilized SOC by priming, resulting in increased $\mathrm{CO}_{2}$ efflux. Glyphosate application plus fertilization further increased microbial activity contradicting our hypothesis. In combination with high fertilizer amounts, glyphosate strongly increased microbial activity. NPK might occupy a greater share of sorption capacities; hence, glyphosate is still available and can act as an additional source of $\mathrm{C}$ and possibly $\mathrm{N}$ and $\mathrm{P}$. Therefore, SOC decomposition was 1.5 accelerated compared to the control when glyphosate and fertilizer application were combined. In contrast, reduced SOC decomposition, i.e., a strong negative priming effect $\left(-47.9 \mu \mathrm{g} \mathrm{C}^{-1}\right)$, occurred under reduced NPK fertilization without herbicides suggesting positive effects on $\mathrm{C}$ accumulation and storage. Our results emphasize the risk of management intensification and the need for a low-impact management strategy to maintain soil fertility and the function as a $\mathrm{C}$ reservoir.

Keywords: oil palm, SOC decomposition, priming effects, fertilization, glyphosate 


\subsubsection{INTRODUCTION}

The high demand of oil palm products has led to an expansion of oil palm cultivation area from about 2 Mha to about 9 Mha from 2000 to 2017 in Indonesia. With this, Indonesia is the world's largest oil palm producer (FAOSTAT, 2019). The disappearance of primary and secondary rainforests in South East Asia is a direct consequence of oil palm cultivation. The land-use change from forests to plantations includes reduced aboveground biomass and litter input, leading to high soil organic carbon (SOC) losses, due to erosion and increased mineralization from older C pools (Guillaume et al., 2015; Rahman et al., 2018). Therefore, in agricultural transformation systems a lower net primary production has been found than in rainforests (Guillaume et al., 2018). Soil organic matter (SOM) decomposition under oil palm cultivation has been a research focus in recent years (Guillaume et al., 2015; Haron et al., 1998; Pransiska et al., 2016; Smith et al., 2012). The additional impact of fertilizers on SOM decomposition in oil palm plantations was studied less intensive and often with a focus on natural organic amendments e.g. application of empty fruit bunces or mulching (Boafo et al. 2019). Typical management practices on oil palm plantations are nitrogen-phosphorouspotassium (NPK) fertilization as well as herbicide spraying e.g., glyphosate for weed control (Baylis, 2000; O Duke and Powles, 2008; Wibawa et al., 2009). Management practices of oil palm plantation can have severe environmental impacts and further decrease soil $\mathrm{C}$ storages (Guillaume et al., 2016a, 2015; Woittiez et al., 2019). The uneven application of $\mathrm{N}$ fertilizer for instance can lead to $\mathrm{N}$ leaching (Kurniawan et al., 2018) and higher $\mathrm{N}_{2} \mathrm{O}$ emissions in the strong fertilized circle around the palms (Hassler et al., 2017). In oil palm plantations, management practices and SOM decomposition processes vary spatially, since oil palm plantations have a distinct structure with different management zones. The palms are planted in rows and have a circle of approximately $2 \mathrm{~m}$ in diameter around the trunk. These circles are often called weeding or weeded circles, and within the circles, fertilizers are applied, and vegetation is removed mechanically or by herbicide application. Thus, low understory vegetation leads to a loss of SOC and soil macrofauna richness as well as increased erosion (Ashton-Butt et al., 2018; Guillaume et al., 2015). Interrows (IR) border the weeding circles (WC), do not receive fertilizers but vegetation is removed as well (Ashton-Butt et al., 2018; Comeau et al., 2016; Darras et al., 2019). Further, in many oil palm plantations palm fronds are piled-up either in IR or between the palms. Frond piles provide often the only $C$ input to soils within the whole plantation (Guillaume et al., 2015; Ramos et al., 2018; Rüegg et al., 2019). 
In terrestrial ecosystems, soil microbes are mainly $\mathrm{C}$ and energy limited (Hobbie and Hobbie 2013; Soong et al. 2020). If fresh C is provided, e.g., from root exudates (e.g., sugars) of understory biomass or oil palms themselves, energy becomes available. This leads to a faster nutrient turnover and to a higher nutrient demand. Hence, microbial growth and activity is stimulated, leading to extra mining of nutrients from SOM and causing an accelerated decomposition. This process is called positive priming by nutrient mining (Fontaine et al., 2003; Kuzyakov et al., 2000). In contrast, microorganisms may preferentially use mainly the easily available C source, and do not mine extra nutrients out of "older" organic matter, if required nutrients are present sufficiently. This preferential microbial substrate utilization causes negative priming effects, leading to reduced decomposition (Blagodatskaya et al., 2007; Kuzyakov and Bol, 2006). An additional factor influencing SOM decomposition is chemical weed control. In oil palm plantations, glyphosate, a non-selective broad-spectrum herbicide, is commonly used for weed control. It prevents plant growth by deactivating the enzyme 5enolpyruvylshikimate-3-phosphate synthase (EPSPS), which synthesizes amino acids essential for plant survival (O Duke and Powles, 2008). The synthesizing pathway is also present in microorganisms, which decompose glyphosate (Mamy et al., 2016; Nguyen et al., 2016; Van Bruggen et al., 2018). Although microorganisms are not target organisms, glyphosate might their microbial activity and growth (Pollegioni et al., 2012). Data about influence of glyphosate on microorganisms are inconsistent. Some studies showed that glyphosate changes the soil microbial community composition (Van Bruggen et al., 2018), whereas other studies did not find any effects on microbial communities (Zabaloy et al., 2016). It is assumed that the impact of glyphosate on microbial biomass is dependent on soil properties, especially $\mathrm{pH}$, SOC content and texture (Nguyen et al., 2016) and cannot simply be generalized but needs to be determined for the respective study objects.

The aim of our study was to gain a mechanistic understanding about the impact of common agricultural management practices (fertilizer and herbicide application) on SOC decomposition in oil palm plantations. We stimulated microbial activity and investigated priming effects by adding easily available C source - glucose - to soil from an oil palm plantation with contrasting management regimes in a 33 days incubation experiment.

We hypothesize that (1) activation of microorganisms due to $\mathrm{N}$ fertilization leads to faster SOC decomposition and so, increased soil $\mathrm{CO}_{2}$ emissions. Secondly, we hypothesized that (2) 
herbicide application increases SOC sequestration, as it counteracts the fertilizer's effects by hampering soil microbial activity via the deactivation of the shikimate pathway involved in microbial amino acid synthesis, thus leading to decreased microbial respiration.

\subsubsection{MATERIALS AND METHODS}

\subsubsection{Study Site}

The study was conducted on a large-scale oil palm plantation in Jambi Province in Sumatra, Indonesia $\left(1^{\circ} 23^{\prime} \mathrm{S}, 103^{\circ} 23^{\prime} \mathrm{E}\right)$. The state-owned and managed oil palm plantation PTPN VI is between 17 - 21 years old. The soil was classified according to the IUSS Working Group WRB 2014 as an Acrisol with sandy loam texture. Mean annual temperature is $26.7^{\circ} \mathrm{C}$ and average rainfall $2075 \mathrm{~mm}$ with two precipitation peaks in March and November (Darras et al., 2019).

The laboratory experiment was based on a field experiment conducted by the CRC 990, a collaborative research cluster between the University of Göttingen, Germany and the Universities of Jambi, Bogor and Palu, Indonesia. The field experiment compared four management practices on four 50x50 m plots with four field replications. These plots have two characteristic locations: WC a $2 \mathrm{~m}$ radius circle around the single palms, where the fertilizer is applied, and the IR between the palm rows.

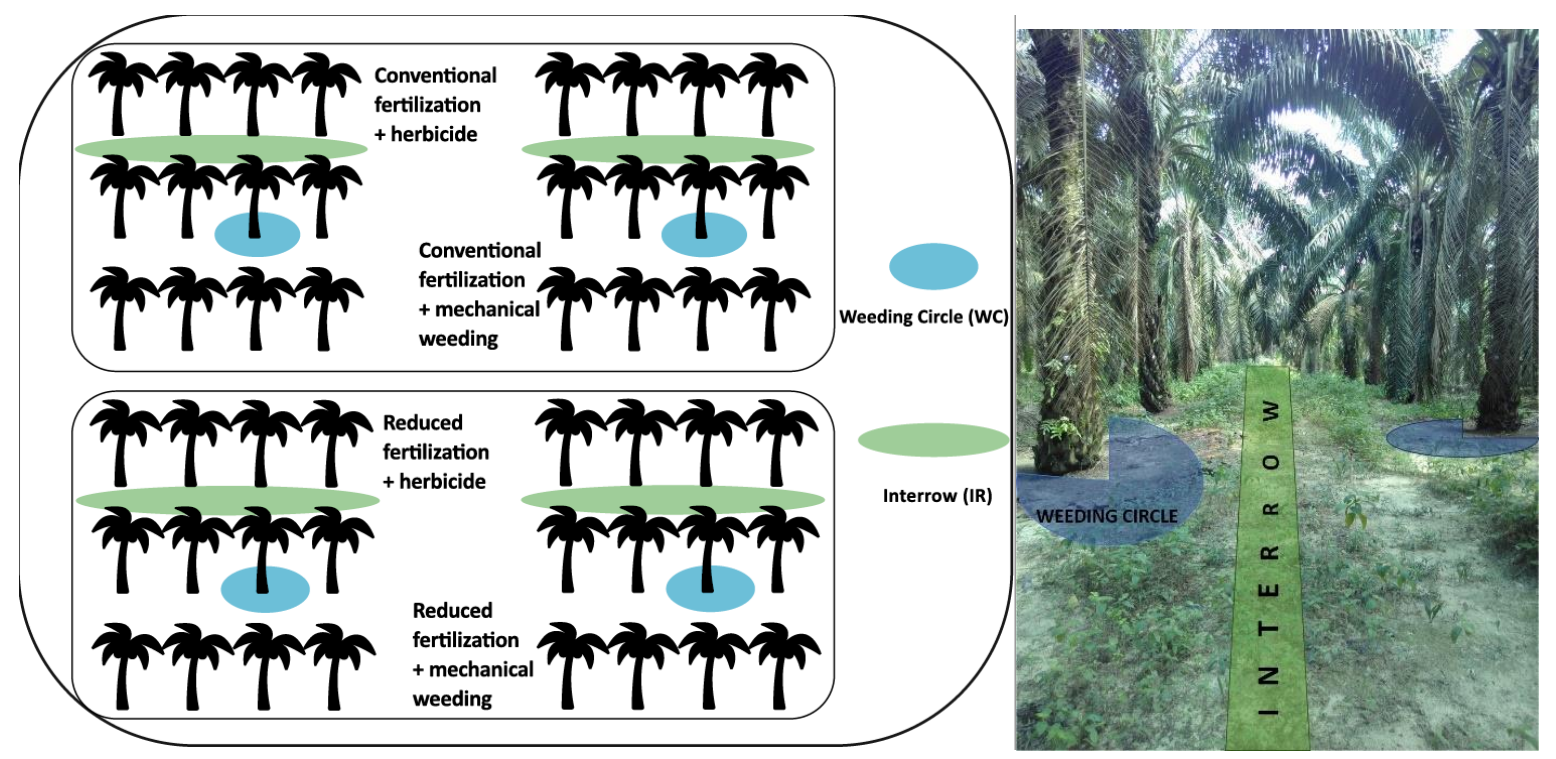

Figure 2.4-1: Scheme of the experimental design in the field (left): intensive management practices with conventional fertilization and herbicide application and conventional fertilization and mechanical weeding for weed control and extensive management practice with reduced fertilization and herbicide application and reduced fertilization with mechanical weeding. Typical structure of an industrial oil palm plantations (right): Weeding Circles (WC) of $2 \mathrm{~m}$ radius around each palm, where fertilizer and herbicide are applied or mechanical weeding is chosen for weed control. The interrow (IR) between the palm rows receives herbicide or is mechanically weeded but no fertilizer is applied here. 
The four management practices were: 1) a conventional level + herbicide application, 2) conventional fertilization level + mechanical weeding, 3) a reduced fertilization level + herbicide and 4) a reduced fertilization level + mechanical weeding (Figure 2.4-1).

The conventional fertilization level consisted of $4 \mathrm{~N}, 1.8 \mathrm{P}$ and $3.2 \mathrm{~K} \mathrm{~kg}$ per WC year-1. The reduced fertilization level comprised $2 \mathrm{~N}, 0.6 \mathrm{P}$ and $2.6 \mathrm{~K}$ per WC year-1. Both fertilization levels were applied in a radius of about $1 \mathrm{~m}$ from the palm base. The rates were divided into two applications per year. The conventional fertilization rates correspond to those practiced on large-scale plantations in Jambi Province. The reduced fertilization rates were based on the exported amount of NPK from the harvested fruit bunches (Darras et al., 2019). Herbicide application (Glyphosate) around each palm is $1500 \mathrm{~cm}^{3} \mathrm{ha}^{-1}$ year-1 with four applications per year, whereas in the IR a reduced rate of $750 \mathrm{~cm}^{3} \mathrm{ha}^{-1}$ year-1 with two applications was done. Mechanical weeding was done around each palm in $2 \mathrm{~m}$ radius from the palm base and four times per year and in the IR twice per year.

\subsubsection{Sampling and preparation}

Soil samples were collected in September 2016 from the first $30 \mathrm{~cm}$ soil depth of WC and IR from all management practices. Composite samples consisting of 25 subsamples were collected to cover soil variability at the plot scale. The soil was air-dried and sieved (2 mm) and all visible roots were carefully removed.

\subsubsection{Laboratory experimental design}

36 grams of the air-dried soil were adjusted to $60 \%$ of water holding capacity and preincubated for 28 days at constant $27^{\circ} \mathrm{C}$ (equivalent to Jambi's average temperature) in glass jars to prevent any effect of the rewetting on $\mathrm{C}$ mineralization and microbial biomass during the main experiment ( $\mathrm{Wu}$ and Brooks, 2005). The $\mathrm{CO}_{2}$ emissions were trapped in $2 \mathrm{ml} 1 \mathrm{M}$ $\mathrm{NaOH}$ solution. $\mathrm{CO}_{2}$ was collected four times during pre-incubation. Considering the fertilization levels in the field, $3.8 \mathrm{mg}$ urea, $1.7 \mathrm{mg}$ TSP and $2.7 \mathrm{mg} \mathrm{KCl}$ were applied per gram soil to simulate the conventional fertilization level. To simulate the reduced fertilization level, $1.7 \mathrm{mg}$ urea, $0.5 \mathrm{mg}$ TSP and $2.0 \mathrm{mg} \mathrm{KCl}$ were applied per gram soil. Glyphosate concentrations were $0.03 \mu \mathrm{gr}^{-1}$ soil in the WC and in the IR. Fertilizer and herbicide were added to the incubated soil after three days of pre-incubation. Instead of the mechanical weeding practice, non-glyphosate amended soil was used, because the incubated soil did not have plant material 
to weed. After the pre-incubation period, when respiration stabilized, ${ }^{14} \mathrm{C}$ labelled glucose as an aqueous solution was added to the soil. The glucose was applied by a fine pipette tip to the soil as uniform as possible. Another identical sample set was used as the control group without any ${ }^{14} \mathrm{C}$ glucose amendment. The control group received the same volume of water instead of the glucose solution. After glucose addition, all samples were incubated at $27^{\circ} \mathrm{C}$ in the dark for 33 days. The $\mathrm{CO}_{2}$ sampling took place at day 1, 2, 3, 4, 6, 8, 13, 18, 23, 28 and 33. After finishing the experiment, soil samples were stored at $4{ }^{\circ} \mathrm{C}$ until further analysis. $\mathrm{NaOH}$ solutions and DNA subsamples were stored at $-20{ }^{\circ} \mathrm{C}$ until $\mathrm{CO}_{2}$ measurement.

\subsubsection{Analyses}

The amount of $\mathrm{C}$ in $\mathrm{NaOH}$ samples was analyzed by a 2100 TOC/TIC analyzer (Analytik Jena, Jena, Germany) in an aliquot of $0.2 \mathrm{ml}$ with a $1: 15$ dilution. ${ }^{14} \mathrm{C}$ activity in ${ }^{14} \mathrm{C}$-glucose labelled samples was measured by a liquid scintillation counter (300 SL Hidex, Turku, Finland). For this, $0.3 \mathrm{ml}$ of the $\mathrm{NaOH}$ solution was mixed with $2 \mathrm{ml}$ of the ROTISZINT LSC-universal scintillation cocktail (Carl Roth, Karlsruhe, Germany). dsDNA for carbon in microbial biomass (MBC) estimation was determined using a FastDNA Spin Kit for Soil (MP Biomedicals, Santa Ana, USA) following the supplier's instruction. The dsDNA content was measured by a NP80 NanoPhotometer (Implen, Munich, Germany). MBC was estimated by multiplying the dsDNA with the correction factor 5.0 (Anderson and Martens, 2013). Soil water content was determined drying five grams of soil at $105^{\circ} \mathrm{C}$ and weighed again.

\subsubsection{Calculations and statistics}

The basal respiration was calculated as the mean of stabilized respiration rates during preincubation, shortly before ${ }^{14} \mathrm{C}$ glucose addition. Glucose mineralization was calculated as the percentage of ${ }^{14} \mathrm{C}$ derived from the total added ${ }^{14} \mathrm{C}$ glucose. To present the cumulative priming effect after 33 days of incubation we used $\Sigma$ total $\mathrm{CO}_{2}, \Sigma$ glucose-derived $\mathrm{CO}_{2}$ and $\Sigma$ SOMderived $\mathrm{CO}_{2}$. Priming effects are expressed as the difference of the $\mathrm{SOM}$-derived $\mathrm{CO}_{2}$ from soil with glucose amendment and the SOM-derived from soil without glucose amendment (Blagodatskaya et al., 2007) and were calculated according to the following equation:

$$
\mathrm{PE}\left(\mu \mathrm{g} \mathrm{C} \mathrm{g}{ }^{-1} \text { soil }\right)=\mathrm{CO}_{2} \text { som-derived- } \mathrm{CO}_{2} \text { control }
$$

where

$$
\mathrm{CO}_{2} \text { som-derived }=\text { Total } \mathrm{CO}_{2}-\mathrm{CO}_{2} \text { glucose-derived }
$$


The glucose-derived $\mathrm{CO}_{2}$ was calculated according to the specific ${ }^{14} \mathrm{C}$ activity of the added glucose (14C; DPM), where ${ }^{14} \mathrm{CO}_{2}$ is the activity in the $\mathrm{CO}_{2}$ efflux (DPM):

$$
\mathrm{CO}_{2} \text { glucose-derived }=\left(\mathrm{C}_{\text {glucose }} \mathrm{X}^{14} \mathrm{CO}_{2} \text { glucose } /{ }^{14} \mathrm{C}_{\text {glucose }}\right.
$$

The metabolic quotient $\left(q \mathrm{CO}_{2}\right)$ was calculated as the ratio of the basal $\mathrm{CO}_{2}$ emission rate and MBC (Anderson and Domsch, 1993). During the experiment we lost control microcosms without glucose amendments in the treatment reduced fertilization and herbicide and reduced fertilization and mechanical weeding. Consequently, there was a reduced number of replicates used for the following priming calculation, i.e., number of replicates of glucose amended and control microcosms was partially not identical. Please consider that the PE of the reduced fertilized treatments were calculated based on and identical set of reference samples irrespective of herbicide treatment due to failure of some microcosms. So, we could underly the priming calculation by a robust number of reference samples $(n=4)$.

All statistics and graphing were done by the statistical software RStudio v1.2.1578 (RStudio Team, 2015) using ggplot2 (Wickham, 2016), lsmeans (Lenth, 2016b), multcomp (Hothorn et al., 2008) and multcompView (Graves et al., 2019). The combined effects of fertilizer levels, weed control and soil sampling location were tested using a Three-Way ANOVA at $p$-level < 0.05 with factor interactions. Tukey HSD post-hoc analysis was used for group comparisons. Variances between the groups were homogeneous (Levene's test $p$-level $>0.05$ ) and normally distributed (Shapiro-Wilk test $\mathrm{p}<0.05$ ) for basal respiration and priming effects. Metabolic quotient data were log-transformed, to correct for a non-normal distribution.

\subsubsection{RESULTS}

Highest $\mathrm{CO}_{2}$ efflux was stated from soil from WC with conventional fertilizer level + herbicide application (0.04 $\mathrm{mg} \mathrm{CO}_{2} \mathrm{~g}^{-1}$ day $^{-1}$ ) (Figure 2.4-2). Less intensive management practices decreased $\mathrm{CO}_{2}$ emissions from soil from WC (Figure 2.4-2). Lowest $\mathrm{CO}_{2}$ efflux from soil from the WC was measured under reduced fertilization level + mechanical weeding $\left(0.02 \mathrm{mg} \mathrm{CO}_{2}\right.$ $\mathrm{g}^{-1}$ day $\left.^{-1}\right) \cdot \mathrm{CO}_{2}$ efflux from soil from WC were significantly higher than from IR across all management practices. $\mathrm{CO}_{2}$ efflux was 4 times higher from soil from the WC with conventional fertilizer level and herbicide than in the corresponding IR. There were no differences between $\mathrm{CO}_{2}$ emissions from soil from the IR between the management practices. 


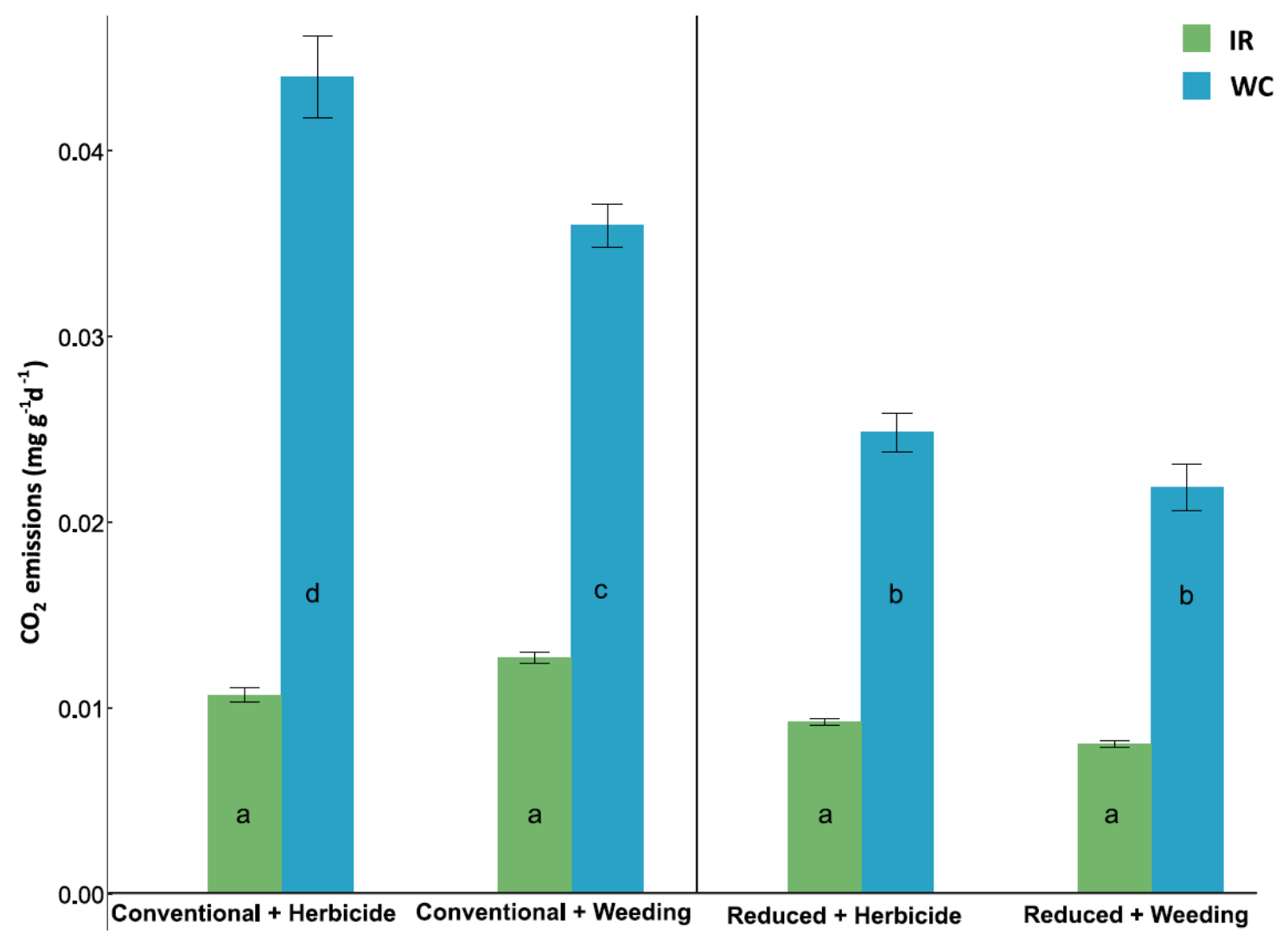

Figure 2.4-2: Basal respiration $\left(\mathrm{CO}_{2}\right)$ from incubated soil from different treatments in WC and IR. Values are presented in means $(n=4)$. Error bars represent the standard error of the mean. Letters indicate significant differences between fertilizer, herbicide and locations.

The metabolic quotient $\left(q \mathrm{CO}_{2}\right)$ indicates the efficiency of microorganisms decomposing organic matter. The $q \mathrm{CO}_{2}$ values measured in the soil from WC under less intensive management practices were higher $(p<0.05)$ than in the corresponding IR and the other IRs under more intensive management practices (Figure 2.4-3). 


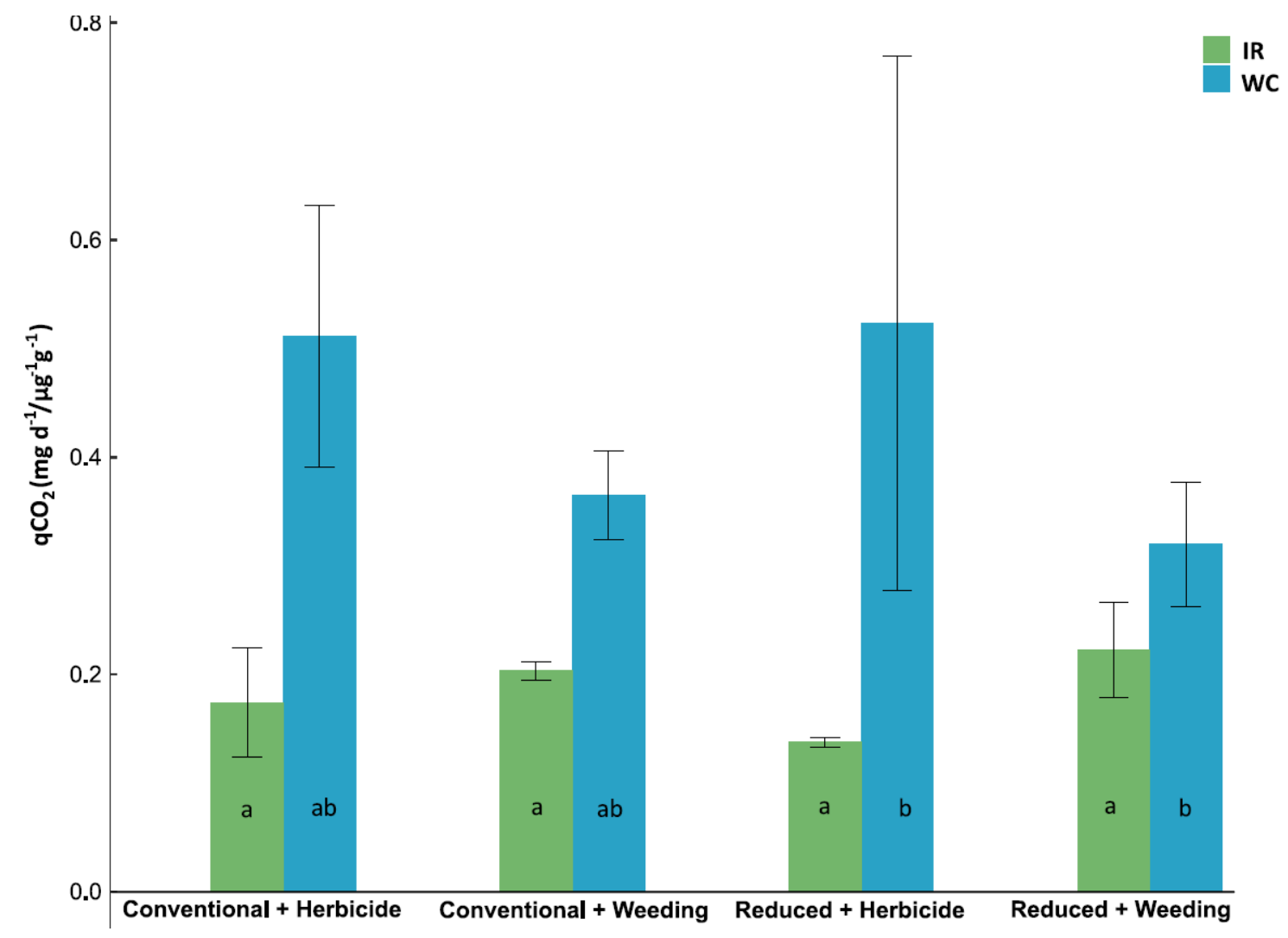

Figure 2.4-3: Metabolic quotient $\left(q \mathrm{CO}_{2}\right)$ calculated as the ratio of basal respiration to $C$ in microbial biomass. Values are presented as means $(n=4)$. Error bars represent the Standard Error of Mean (SEM). Letters indicate significant differences between fertilizer, herbicide and locations according to 3-Way-ANOVA on logtransformed data $(p<0.05)$.

After the second day of incubation, $\mathrm{CO}_{2}$ emission rates were always higher from WC soil than in the IR across all treatments $(p<0.05)$ (Figure 2.4-4). The maximal $\mathrm{CO}_{2}$ emission rates from glucose-amended soils were measured at the second day of incubation and were around 1.5 times higher than from their corresponding control group $(p<0.05)$. 

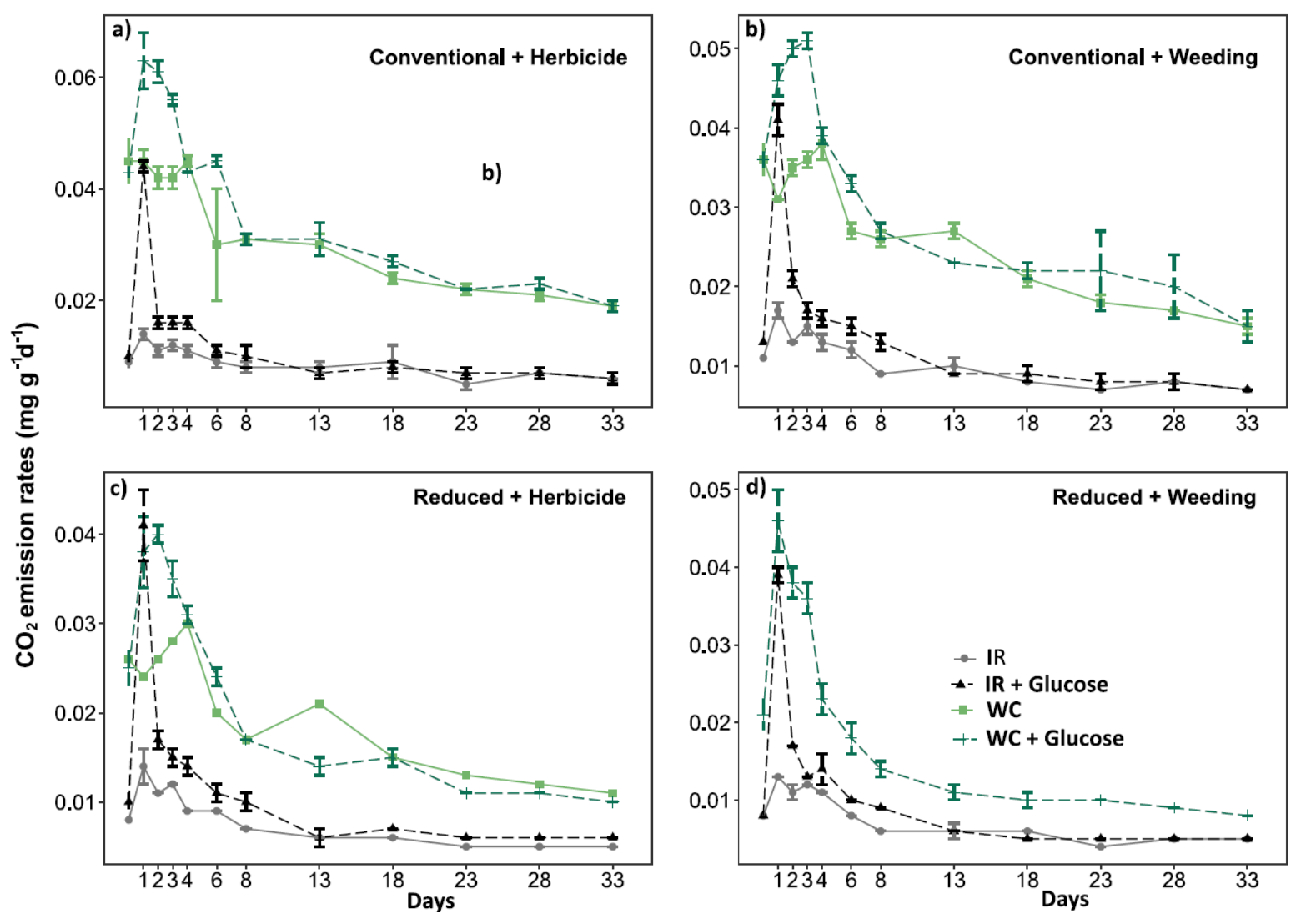

Figure 2.4-4: $\mathrm{CO}_{2}$ emission rates $\left(\mathrm{mg} \mathrm{g}^{-1} \mathrm{~d}^{-1}\right)$ from glucose and control group over the 33 days of incubation of the soil from conventional fertilization with herbicide and mechanical weeding and reduced fertilization and herbicide and mechanical weeding in WC and IR. IR did not receive fertilizer but herbicide or were mechanically weeded. Data are presented as means ( $n=4$, except for the treatment "WC reduced fertilization level + herbicide" $n=1$ ). Error bars indicate the standard error of the mean.

$\mathrm{CO}_{2}$ effluxes decreased from day 2 till 33 across all management practices and locations. $\mathrm{CO}_{2}$ efflux rates from decomposition of glucose and SOC in the WC were continuously higher than the corresponding $\mathrm{CO}_{2}$ emission rates in the IR- a phenomenon especially expressed under conventional fertilization. 

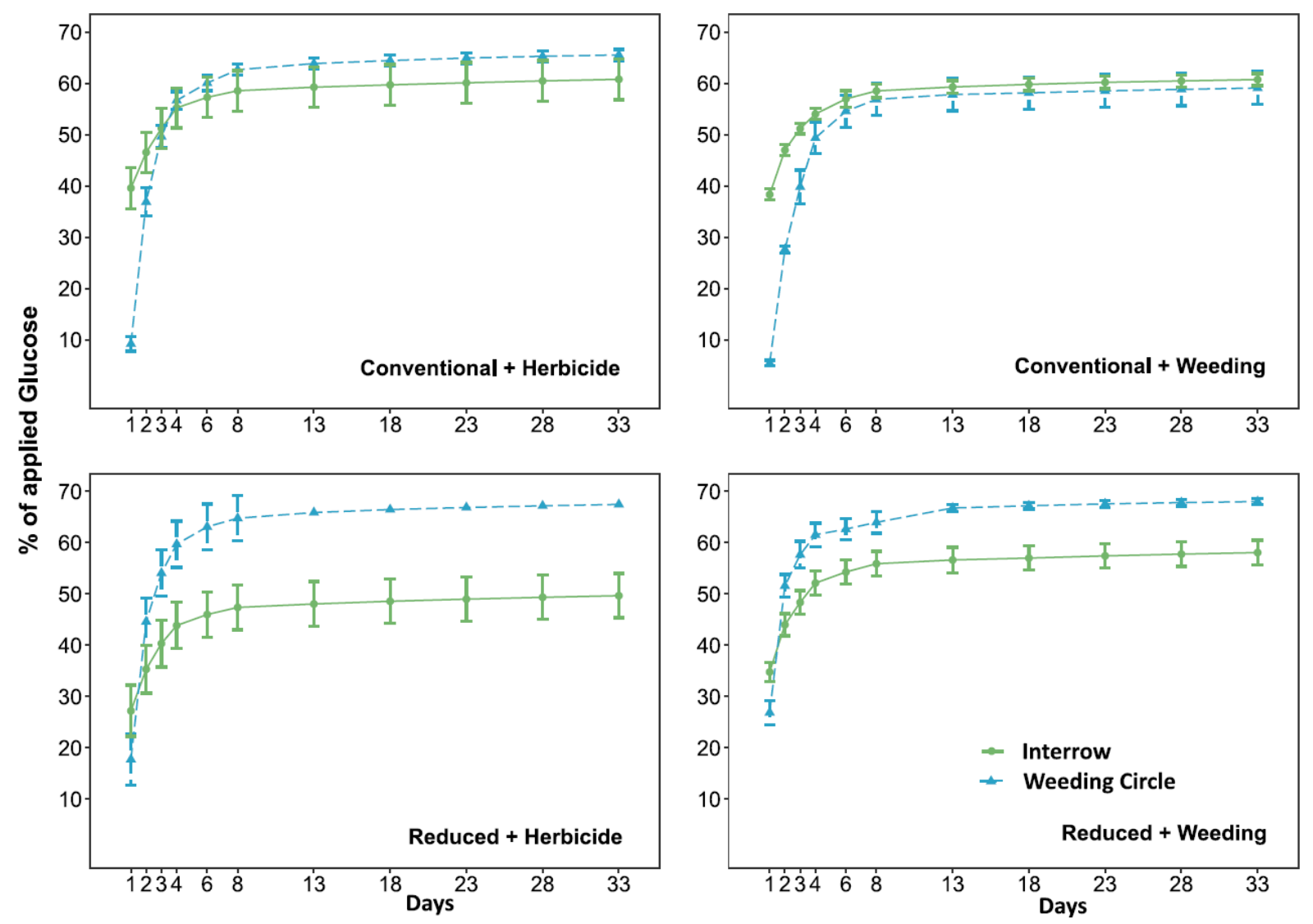

Figure 2.4-5: Cumulative $\mathrm{CO}_{2}$ emissions from glucose decomposition over the 33 days of incubation of the soil from the conventional fertilization with herbicide and mechanical weeding and reduced fertilization with herbicide and mechanical weeding. Data are presented as means $(n=4)$. Error bars indicate the standard error of the mean.

The cumulative $\mathrm{CO}_{2}$ emissions from glucose decomposition displays the percentage respired from glucose but not from SOM. It increased during the first four days to up to $61 \%$ in the WC and $55 \%$ in the IR. After the $6^{\text {th }}$ incubation day glucose was consumed up to $68 \%$ from the reduced fertilized and non-glyphosate amended soil (Figure 2.4-5a, c, d). Under conventional fertilization levels (with and without glyphosate) the $\mathrm{CO}_{2}$ emissions from WC and IR soils narrowed again after the $6^{\text {th }}$ day of incubation (Figure 2.4-5a, b). Conversely under reduced fertilization levels, cumulative emissions of glucose-derived $\mathrm{CO}_{2}$ were concisely higher in the WC than in the IR with continuous measures (Figure 2.4-5c, d).

The highest peak of $\mathrm{CO}_{2}$ emission from glucose decomposition in the IR occurred one day earlier than in the WC. This was especially obvious under conventional fertilization, where the WC of the conventional fertilized plot has a glucose respiration of $28 \%$ at the $2^{\text {nd }}$ day, whereas the respiration rate is $40 \%$ from corresponding IR at the $1^{\text {st }}$ day (Figure 2.4-5a) also compare with glucose respiration rates per day, Appendix A 2.4-1). The priming effect was almost always negative, except if herbicides are applied on conventionally fertilized WC or reduced 
fertilized IR, which both showed the absence of any priming effect (Figure 2.4-6). Less intensive management practices increased negative priming effects in WC. The negative priming effect measured from WC soil under reduced fertilization + mechanical weeding (no glyphosate) was significantly higher $\left(-47.9 \mu \mathrm{g} \mathrm{C}^{-1}\right)$ than priming effects in any other location or under any other treatment.

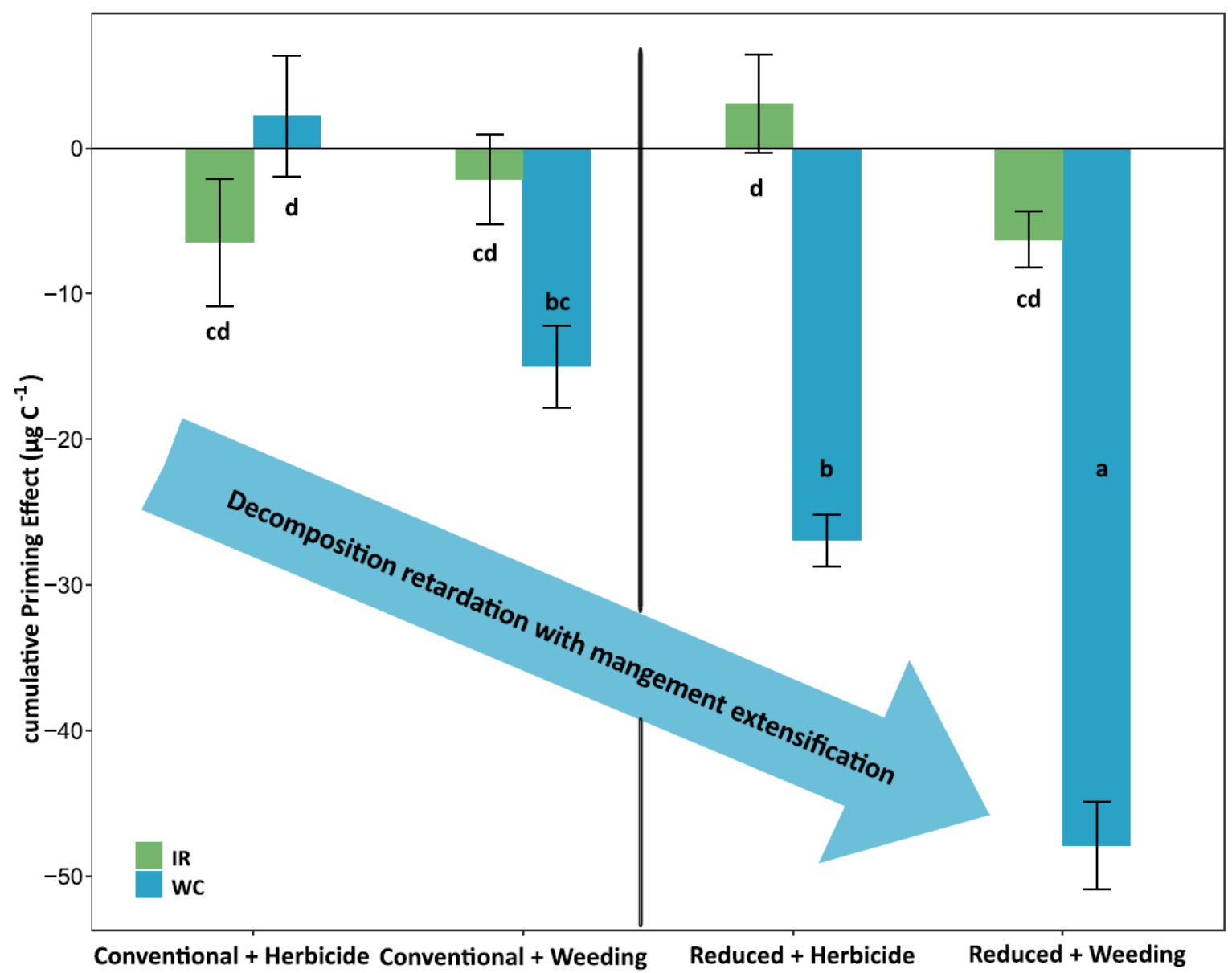

Figure 2.4-6: Cumulative Priming Effects across all management practices and locations after 33 days of soil incubation of the soil from the conventional fertilization with herbicide and mechanical weeding and reduced fertilization with herbicide and mechanical weeding. Values are presented as means $(n=4)$. Error Bars indicate the standard error of the mean. Letters indicate significant differences between fertilizer, herbicide and locations according to 3-Way-ANOVA with TukeyHSD post-hoc comparison $(p<0.05)$. 
Intensive management practices

Extensive management practices

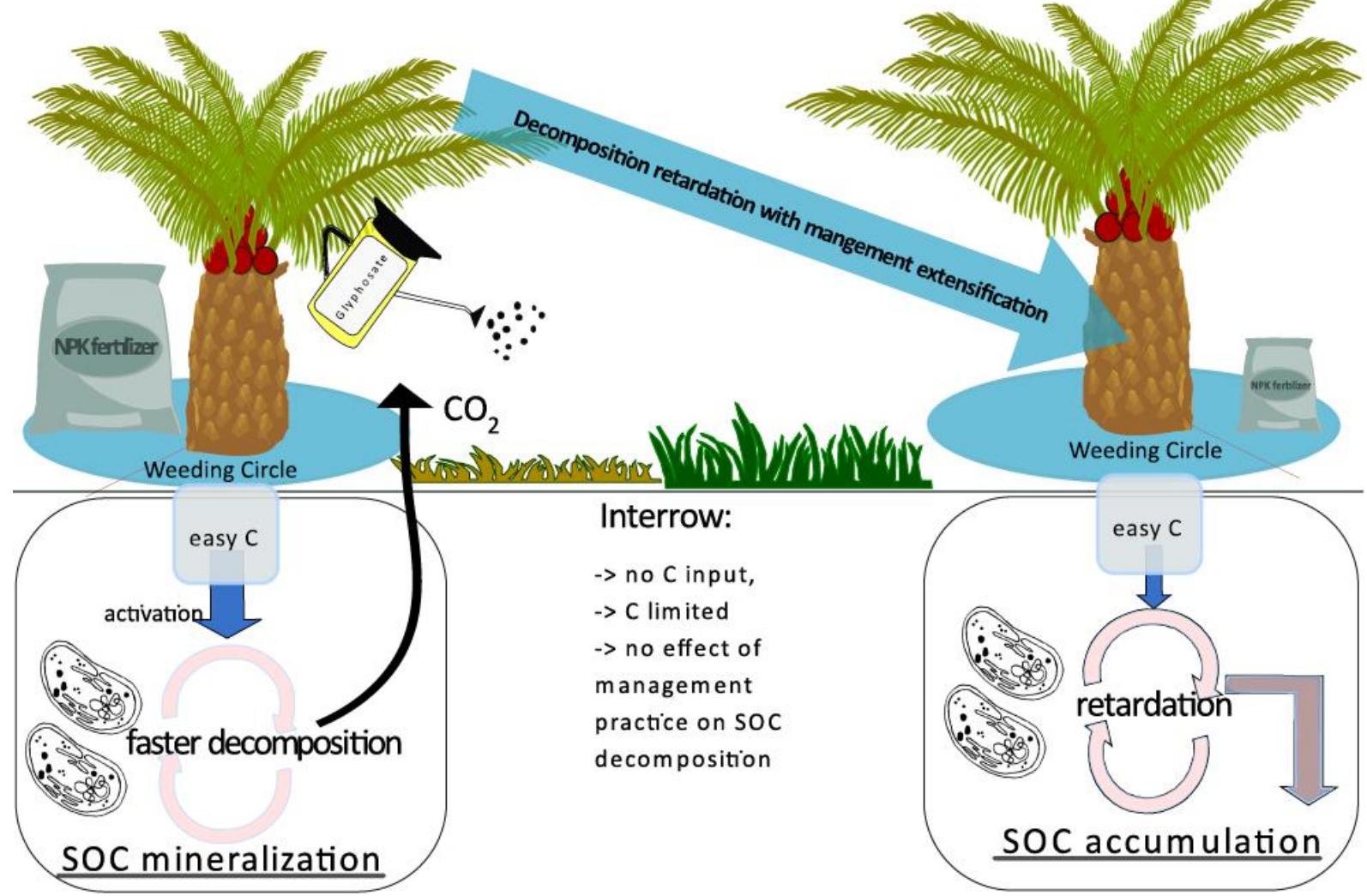

Figure 2.4-7: Summary of research outcomes: Decomposition responses towards contrasting management practices. Faster decomposition and higher $\mathrm{CO}_{2}$ efflux under conventional fertilization level and herbicide application. Retarded SOC decomposition and support of SOC accumulation under reduced fertilization and mechanical weeding. Effects most prominent in the WC. IRs mostly characterized by missing C input and C limitation. No effects of management extensification could be found in the IRs.

\subsubsection{DISCUSSION}

\subsubsection{Effect of management practices on SOC decomposition and microbial} response

We aimed to gain a mechanistic understanding about the impact of common agricultural management practices (fertilizer + herbicide application) on SOC decomposition in oil palm plantations. In line with our first hypothesis, intensive management practices (conventional fertilization + glyphosate or mechanical weeding) increased microbial activity, indicated by higher $\mathrm{CO}_{2}$ emissions, compared to extensive management practices (reduced fertilizer + glyphosate or mechanical weeding). Fertilization increased nutrient availability (Marschner et al., 2003), stimulates microbial activity and does not require energy-intensive mechanisms of nutrient mining e.g. via exoenzyme production. This saves $C$ and energy for the microorganisms, which finally leads to increased soil respiration (Figure 2.4-2) (Chu et al., 
2007; Comeau et al., 2016). This agrees with results of a meta-analysis which showed that $\mathrm{N}$ additions lead to an increase in soil respiration of $12.4 \%$ in croplands (Zhou et al., 2014). Intensive management practices caused higher basal respiration i.e., accelerated SOM decomposition under C limitation, but there was no further acceleration of SOC decomposition (i.e., positive PE). If labile substrate was readily available, but showed higher $\mathrm{CO}_{2}$ emissions than under extensive management practices (Figure 2.4-6). Instead, extensive management practices (reduced fertilization + glyphosate and mechanical weeding) decreased $\mathrm{CO}_{2}$ emissions and SOC decomposition by leading to pronounced negative priming effects (Figure 2.4-6). Reduced fertilization and the absence of glyphosate led to strongest negative priming, indicating a retardation of SOC decomposition (Kuzyakov et al., 2000).

Contrary to our second hypothesis that glyphosate application would hamper microbial activity and lead to reduced SOC decomposition, the absence of glyphosate decreased $\mathrm{CO}_{2}$ emissions and thus SOC decomposition. Glyphosate application in combination with high amounts of fertilizers, had the opposite effect (Figure 2.4-2) and increased microbial activity thus increasing the decomposition of SOC, emitted as $\mathrm{CO}_{2}$ to the atmosphere (Figure 2.4-6). These results indicate that glyphosate was available as an additional $C$ source for microorganisms leading to an increased microbial activity. The positive impact of glyphosate on microbial activity, especially after repeated applications for several years, and its degradation for energy-acquiring processes has also been previously reported (Araújo et al., 2003; Busse et al., 2001). Several studies found glyphosate concentration as one of the main factors for stimulating or weakening soil microbial respiration (Abood et al., 2015; Duke et al., 2012; Guijarro et al., 2018; Haney et al., 2000). Nguyen et al. (2016) found that concentrations of $>200 \mathrm{mg} \mathrm{kg}^{-1}$ soil did increase microbial respiration. As glyphosate concentration applied in this experiment were $375 \mathrm{mg} \mathrm{kg}^{-1}$ soil, resembling field application conditions, those findings agree with our interpretation that glyphosate rather increased than lowered microbial respiration. The $q \mathrm{CO}_{2}$ values support this assumption, as the $q \mathrm{CO}_{2}$ tended to be higher in $\mathrm{WC}$ with herbicide application compared to WC without herbicide application (Figure 2.4-3). Thus, blockage of the shikimate pathway does not seem to negatively affect microbial metabolism potentially due to the fact that metabolites that cannot be produced by a cell any more, but can be procured from the environment e.g. by recycling of these compounds from necromass (Bore et al., 2017; Dippold and Kuzyakov, 2016). 
It is known that glyphosate and phosphate from fertilizer compete for the same sorption sites on soil particles (Jonge and Jonge, 1999; Munira et al., 2018). Glyphosate application in combination with long-term phosphate fertilization most likely led to a reduced glyphosate sorption to soil particles, because pre-sorbed phosphate occupied the sorption sites that would be otherwise available to glyphosate. This effect is even stronger in acidic soils such as our sandy loam Acrisol, and is most pronounced when both are added at the same time (Gimsing et al., 2007; Munira et al., 2018). Soil microbial biomass and soil microbial respiration are more sensitive toward glyphosate in soils having a $\mathrm{pH}$ between $5.5-7.5$ than in soils with a $\mathrm{pH}<5.5$ (Nguyen et al., 2016), which agrees with our measured pH values varying between 4.8 and 5.3. The sandy (more coarse-textured) soil only offered reduced number of sorption sites compared to fine-textured soils i.e. clay, whereby glyphosate decomposition by microorganisms is slowed down (Guijarro et al., 2018). Therefore, we conclude no systematic inhibition of microbial activity by glyphosate application. Nguyen et al. (2016) postulates that glyphosate application in soils with low organic carbon content increases the microbial C respiration and reduces soil microbial biomass. Although, our SOC data are low $(0.78 \%-2.1 \%$ in IR and WC, respectively) as typical for soils under oil palm cultivation (Guillaume et al., 2015), we cannot state a reduction of soil microbial biomass. We consider a long-term adapted microbial community after several years of glyphosate application, whereas Nguyen et al. (2016) proposes limited microbial functionality and a less well buffer against stress factors. Especially for soils undergoing its first glyphosate application, this might be a valid interpretation.

Based on our results we cannot exclude that less resilient parts of the soil microbial community may have been inhibited by a high glyphosate concentration, while more resistant groups compensate their functions and are accountable for the increased soil respiration (Nguyen et al., 2016). An alternative explanation might be that microorganisms sensitive for glyphosate die and their necromass is decomposed by more glyphosate-tolerant microorganisms, explaining the increased $\mathrm{CO}_{2}$ emissions. However, one year after the start of the corresponding field experiment, no significant differences for biodiversity or community composition between the different treatments at entire (DNA-derived) and active (RNA-derived) community level were detected (Berkelmann et al., 2020). We, therefore, propose rather an increase of microbial activity across the whole community than a compensation of functions by special species. 


\subsubsection{Nutrient limitation in management zones}

Basal respiration rates in IR were significantly lower than in the WC, which can be explained by the lack of fertilizer application leading to a reduced nutrient supply for microorganisms. There was no effect of management practices on basal respiration between the IR regardless if they were treated with glyphosate or mechanically weeded. Their location next to either conventional or reduced fertilized WC did not play any role. Consequently, if basal respiration rates did not differ significantly from each other in the IR a massive nutrient allocation from the WC towards the IR can largely be excluded. Generally, oil palm plantations often suffer from nutrient and $\mathrm{C}$ limitation due to the absence of fresh litter input, low root biomass, low rhizodeposition (Guillaume et al., 2018; Pransiska et al., 2016; Rüegg et al., 2019) and high nutrient leaching (Kurniawan et al., 2018). Especially, the IR receive less nutrients due to the absence of fertilizers and less $C$ due to the absence of litter and oil palm rhizodeposits. Our data suggest that C-limitation is strong in IR across all management practices and is largely restricting the microbial activity in these soils.

$\mathrm{C}$ limitation is reduced by adding glucose, simulating rhizodeposits by providing a labile $\mathrm{C}$ source. Generally, microbial biomass quickly switches from a dormant to an active state once supplied with large amounts of labile C (Blagodatsky and Richter, 1998), which explains highest glucose respiration rates shortly after glucose amendment. Across all management practices the maximum peak of glucose decomposition occurred one day earlier in the IR than in the WC. This hints at different metabolic kinetics and microbial responses on labile C. It is likely, that the glucose in the WC was taken up by microbial biomass (at least cytosolic pools) in these much less $\mathrm{C}$ limited microbial communities. As no massive microbial biomass growth is triggered by the glucose amendment, the glucose can during the next days be partitioned to preferable metabolic pathways one of them being respiration (Gunina et al., 2017). However, IR showed immediately the highest glucose respiration: This is indicated by rapid, massive microbial activation as presumably the most limiting factor of microbial activity and growth was removed by the glucose $\mathrm{C}$ addition. Consequently, the glucose was rapidly metabolized and respired. Interestingly, only $50 \%$ of the glucose was respired in the IR under reduced fertilization level, whereas in all WC and also in the IR under conventional fertilization level the glucose was respired up to $68 \%$ during the total duration of the experiment. This suggests that WC fertilization has an effect also on IR microorganisms, providing at least a small 
amount of nutrients available to better make use from a suddenly increased availability of labile C. Microorganisms in the IR under reduced fertilization level seemed to suffer most under nutrient limitation using around $45 \%$ for maintaining their functions.

\subsubsection{Implications for $C$ sequestration in oil palm plantations}

C limitation can be attributed to missing organic input e.g. litterfall or understory vegetation, which also affects $C$ sequestration in soil (Kotowska et al. 2015; Rüegg et al. 2019). The fact that reduced management practices induce reduced SOC mineralization (Figure 2.4-6) implying lower $\mathrm{CO}_{2}$ emissions from soil to the atmosphere indicates that it rather fosters belowground C stabilization. Further, it is known that $\mathrm{C}$ derived from microorganisms (e.g., fungal and bacterial necromass) can in substantial quantities be sequestered in the stable $\mathrm{C}$ pool and contribute to the soil C accumulation (Kindler et al., 2006; Liang et al., 2017; Schweigert et al., 2015). Even though, basal respiration is based either on plant $C$ or microbial necromass, in any case a reduced decomposition of these pools under extensive management will contribute to an SOC accumulation. However, our data suggest that even under extensive management, where we observed highest potential for $\mathrm{C}$ accumulation, microbial communities are largely $\mathrm{C}$ limited in their response. Consequently, to reach the goal of a sustainable management contributing to long-term $\mathrm{C}$ accumulation, it is necessary to ensure above- and belowground C input i.e., by frond piling, application of empty fruit bunches as organic fertilizers. Additionally, organic input accounts for an enhancement of soil fauna growth development (Tao et al., 2017). Further, Darras et al. (2019) showed positive effects of these extensification measures on plant diversity, aboveground arthropods, belowground animals and ecosystem functions, e.g., animal taxa richness, microbial biomass abundance and water infiltration. With the increased potential of $C$ sequestration, we identified another key ecosystem function of oil palm plantations, that might be substantially supported by management extensification.

\subsubsection{CONCLUSIONS}

Intensive fertilization + herbicide application accelerated SOC decomposition, because applied glyphosate concentration in oil palm plantations is very high. This effect was especially pronounced in combination with fertilizer, which acted as an additional nutrient source leading to twice as high soil microbial respiration than under extensive management practices. Extensive management practices i.e., reduced fertilizer level and the absence of glyphosate,

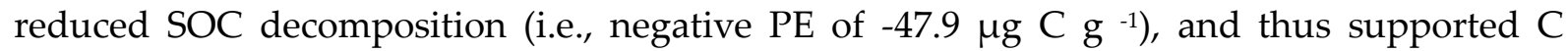


accumulation. In contrast, accelerated SOC decomposition stimulated by intensive agricultural management practices i.e., high fertilizer levels and herbicide application, emphasize the risk of management intensification. We demonstrated that extensive management practices with reduced fertilization levels + mechanical weeding instead of herbicide application bears a high potential to slow down SOM decomposition processes and support $\mathrm{C}$ accumulation after forest conversion to oil palm plantations.

\section{ACKNOWLEDGEMENTS}

This study was funded by the German Research Foundation (DFG) project number 192626868 - SFB 990 in the framework of the collaborative German-Indonesian research project CRC 990. This study was conducted using samples collected based on the Collection permit No. 207/SIP/FRP/E5/Dit.KI/VII/2016 recommended by the Indonesian Institute of Science (LIPI) and issued by the Ministry of Forestry (PHKA). The CRC 990 selected the study sites. We thank PT Perkebunan Nusantara VI (PTPN VI) for granting us access to their oil palm plantation. We would like to thank Winda Januarista and Ardian for their support during field work and Karin Schmidt for her help during laboratory work.

\section{REFERENCES}

Abood SA, Ser J, Lee H, et al (2015) Relative Contributions of the Logging , Fiber, Oil Palm, and Mining Industries to Forest Loss in Indonesia. 8:58-67. doi: 10.1111/conl.12103

Anderson TH, Domsch KH (1993) The metabolic quotient for $\mathrm{CO}_{2}\left(\mathrm{qCO}_{2}\right)$ as a specific activity parameter to assess the effects of environmental conditions, such as $\mathrm{ph}$, on the microbial biomass of forest soils. Soil Biol Biochem 25:393-395. doi: 10.1016/0038-0717(93)90140-7

Anderson TH, Martens R (2013) DNA determinations during growth of soil microbial biomasses. Soil Biol Biochem 57:487-495. doi: 10.1016/j.soilbio.2012.09.031

Araújo ASF, Monteiro RTR, Abarkeli RB (2003) Effect of glyphosate on the microbial activity of two Brazilian soils. Chemosphere 52:799-804. doi: 10.1016/S0045-6535(03)00266-2

Ashton-Butt A, Aryawan AAK, Hood ASC, et al (2018) Understory Vegetation in Oil Palm Plantations Benefits Soil Biodiversity and Decomposition Rates. Front For Glob Chang 1:. doi: 10.3389/ffgc.2018.00010

Baylis AD (2000) Why glyphosate is a global herbicide: Strengths, weaknesses and prospects. Pest Manag Sci 56:299-308. doi: 10.1002/(SICI)1526-4998(200004)56:4<299::AID-PS144>3.0.CO;2-K

Blagodatskaya E V., Blagodatsky SA, Anderson TH, Kuzyakov Y (2007) Priming effects in Chernozem induced by glucose and $\mathrm{N}$ in relation to microbial growth strategies. Appl Soil Ecol 37:95-105. doi: 10.1016/j.apsoil.2007.05.002

Blagodatsky SA, Richter O (1998) Microbial growth in soil and nitrogen turnover: A theoretical model considering the activity state of microorganisms. Soil Biol Biochem 30:1743-1755. doi: 10.1016/S0038-0717(98)00028-5

Berkelmann, D., Schneider, D., Hennings, N., Meryandini, A., Daniel, R., 2020. Soil bacterial community structures in relation to different oil palm management practices. Sci. Data 7, 1-7. https://doi.org/10.1038/s41597-020-00752-3 
Boafo D.K., Boonsong K. PS, Y EBO, A. NP (2019) Effect of organic soil amendments on soil quality in oil palm production. Appl Soil Ecol 103358. doi: 10.1016/j.apsoil.2019.09.008

Bore EK, Apostel C, Halicki S, et al (2017) Soil microorganisms can overcome respiration inhibition by coupling intra-and extracellular metabolism: ${ }^{13} \mathrm{C}$ metabolic tracing reveals the mechanisms. ISME J 11:1423-1433. doi: 10.1038/ismej.2017.3

Busse MD, Ratcliff AW, Shestak CJ, Powers RF (2001) Glyphosate toxicity and the effects of long-term vegetation control on soil microbial communities. Soil Biol Biochem 33:1777-1789. doi: 10.1016/S0038-0717(01)00103-1

Chu H, Lin X, Fujii T, et al (2007) Soil microbial biomass, dehydrogenase activity, bacterial community structure in response to long-term fertilizer management. Soil Biol Biochem 39:2971-2976. doi: 10.1016/j.soilbio.2007.05.031

Comeau LP, Hergoualc'h K, Hartill J, et al (2016) How do the heterotrophic and the total soil respiration of an oil palm plantation on peat respond to nitrogen fertilizer application? Geoderma 268:4151. doi: 10.1016/j.geoderma.2016.01.016

Darras KFA, Corre MD, Formaglio G, et al (2019) Reducing Fertilizer and Avoiding Herbicides in Oil Palm Plantations - Ecological and Economic Valuations. Front For Glob Chang 2:. doi: 10.3389/ffgc.2019.00065

Dippold MA, Kuzyakov Y (2016) Direct incorporation of fatty acids into microbial phospholipids in soils: Position-specific labeling tells the story. Geochim Cosmochim Acta 174:211-221. doi: 10.1016/j.gca.2015.10.032

Duke SO, Lydon J, Koskinen WC, et al (2012) Glyphosate effects on plant mineral nutrition, crop rhizosphere microbiota, and plant disease in glyphosate-resistant crops. J Agric Food Chem 60:10375-10397. doi: 10.1021/jf302436u

FAOSTAT (2019) Crop Production Data. In: Rome Food Agric. Organ. United Nations. http://www.fao.org/faostat/en/\#home. Accessed 19 Sep 2019

Fontaine S, Mariotti A, Abbadie L (2003) The priming effect of organic matter: A question of microbial competition? Soil Biol Biochem 35:837-843. doi: 10.1016/S0038-0717(03)00123-8

Gimsing AL, Szilas C, Borggaard OK (2007) Sorption of glyphosate and phosphate by variable-charge tropical soils from Tanzania. Geoderma 138:127-132. doi: 10.1016/j.geoderma.2006.11.001

Graves, Spencer; Piepho, Hans-Peter; Selzer L (2019) multcompView: Visualizations of Paired Comparisons. $\mathrm{R}$ package version 0.1-8

Guijarro KH, Aparicio V, De Gerónimo E, et al (2018) Soil microbial communities and glyphosate decay in soils with different herbicide application history. Sci Total Environ 634:974-982. doi: 10.1016/j.scitotenv.2018.03.393

Guillaume T, Damris M, Kuzyakov Y (2015) Losses of soil carbon by converting tropical forest to plantations: Erosion and decomposition estimated by $\delta^{13} \mathrm{C}$. Glob Chang Biol 21:3548-3560. doi: 10.1111/gcb.12907

Guillaume T, Holtkamp AM, Damris M, et al (2016) Soil degradation in oil palm and rubber plantations under land resource scarcity. Agric Ecosyst Environ 232:110-118. doi: 10.1016/j.agee.2016.07.002

Guillaume T, Kotowska MM, Hertel D, et al (2018) Carbon costs and benefits of Indonesian rainforest conversion to plantations. Nat Commun 9:. doi: 10.1038/s41467-018-04755-y

Gunina A, Dippold M, Glaser B, Kuzyakov Y (2017) Turnover of microbial groups and cell components in soil: ${ }^{13} \mathrm{C}$ analysis of cellular biomarkers. Biogeosciences 14:271-283. doi: 10.5194/bg-14-2712017

Haney RL, Senseman SA, Hons FM, Zuberer DA (2000) Effect of glyphosate on soil microbial activity and biomass. Weed Sci 48:89-93. doi: 10.1614/0043-1745(2000)048[0089:eogosm]2.0.co;2

Haron K, Brookes PC, Anderson JM, Zakaria ZZ (1998) Microbial biomass and soil organic matter dynamics in oil palm (Elaeis guineensis jacq.) plantations, West Malaysia. Soil Biol Biochem. doi: 10.1016/S0038-0717(97)00217-4

Hassler E, Corre MD, Kurniawan S, Veldkamp E (2017) Soil nitrogen oxide fluxes from lowland forests converted to smallholder rubber and oil palm plantations in Sumatra, Indonesia. Biogeosciences 14:2781-2798. doi: 10.5194/bg-14-2781-2017 
Hobbie JE, Hobbie EA (2013) Microbes in nature are limited by carbon and energy: The starving-survival lifestyle in soil and consequences for estimating microbial rates. Front Microbiol 4:1-11. doi: 10.3389/fmicb.2013.00324

Hothorn, Torsten; Bretz, Frank; Westfall P (2008) Simultaneous Inference in General Parametric Models. Biometrical J 50:346-363

IUSS Working Group WRB (2014) International soil classification system for naming soils and creating legends for soil maps

Jonge H De, Jonge LW De (1999) pH influence on Gly Transport. 39:753-763

Kindler R, Miltner A, Richnow HH, Kästner M (2006) Fate of gram-negative bacterial biomass in soil Mineralization and contribution to SOM. Soil Biol Biochem 38:2860-2870. doi: 10.1016/j.soilbio.2006.04.047

Kotowska MM HD, Triadiati T, Selis M LC (2015) Quantifying above- and belowground biomass carbon loss with forest conversion in tropical lowlands of Sumatra (Indonesia). Glob Chang Biol 21:3620-3634. doi: 10.1111/gcb.12979

Kurniawan S, Corre MD, Matson AL, et al (2018) Conversion of tropical forests to smallholder rubber and oil palm plantations impacts nutrient leaching losses and nutrient retention efficiency in highly weathered soils. Biogeosciences 15:5131-5154. doi: 10.5194/bg-15-5131-2018

Kuzyakov Y, Bol R (2006) Sources and mechanisms of priming effect induced in two grassland soils amended with slurry and sugar. Soil Biol Biochem 38:747-758. doi: 10.1016/j.soilbio.2005.06.025

Kuzyakov Y, Friedel JK, Stahr K (2000) Review of mechanisms and quantification of priming effects. Soil Biol Biochem 32:1485-1498. doi: 10.1016/S0038-0717(00)00084-5

Lehmann J, Kleber M (2015) The contentious nature of soil organic matter. Nature 528:60-68. doi: 10.1038 /nature16069

Lenth R V. (2016) Least Square Means: The R Package lsmeans. J Stat Softw 69:1-33. doi: 10.18637/jss.v069.i01

Liang C, Schimel JP, Jastrow JD (2017) The importance of anabolism in microbial control over soil carbon storage. Nat Microbiol 2:. doi: 10.1038/nmicrobiol.2017.105

Mamy L, Barriuso E, Gabrielle B (2016) Glyphosate fate in soils when arriving in plant residues. Chemosphere 154:425-433. doi: 10.1016/j.chemosphere.2016.03.104

Marschner P, Kandeler E, Marschner B (2003) Structure and function of the soil microbial community in a long-term fertilizer experiment. Soil Biol Biochem 35:453-461. doi: 10.1016/S00380717(02)00297-3

Munira S, Farenhorst A, Akinremi W (2018) Phosphate and glyphosate sorption in soils following longterm phosphate applications. Geoderma 313:146-153. doi: 10.1016/j.geoderma.2017.10.030

Nguyen DB, Rose MT, Rose TJ, et al (2016) Impact of glyphosate on soil microbial biomass and respiration: A meta-analysis. Soil Biol Biochem 92:50-57. doi: 10.1016/j.soilbio.2015.09.014

O Duke S, Powles SB (2008) Mini-review Glyphosate: a once-in-a-century herbicide. Pest Manag Sci 64:319-325. doi: 10.1002/ps.1518

Pollegioni L, Schonbrunn E, Siehl D (2012) Glyphosate; Herbicide Resistance; Herbicide Tolerance; Protein Engineering; Transgenic Crops. 278:2753-2766. doi: 10.1111/j.17424658.2011.08214.x.Molecular

Pransiska Y, Triadiati T, Tjitrosoedirjo S, et al (2016) Forest conversion impacts on the fine and coarse root system, and soil organic matter in tropical lowlands of Sumatera (Indonesia). For Ecol Manage. doi: 10.1016/j.foreco.2016.07.038

Rahman N, De Neergaard A, Magid J, et al (2018) Changes in soil organic carbon stocks after conversion from forest to oil palm plantations in Malaysian Borneo. Environ Res Lett 13:. doi: 10.1088/17489326/aade0f

Ramos HMN, Vasconcelos SS, Kato OR, Castellani DC (2018) Above- and belowground carbon stocks of two organic, agroforestry-based oil palm production systems in eastern Amazonia. Agrofor Syst 92:221-237. doi: 10.1007/s10457-017-0131-4

RStudio Team (2015) RStudio: Integrated Development for R. RStudio, Inc., Boston, MA URL http://www.rstudio.com/. 
Rüegg J, Quezada JC, Santonja M, et al (2019) Drivers of soil carbon stabilization in oil palm plantations. L Degrad Dev 30:1904-1915. doi: 10.1002/ldr.3380

Schweigert M, Herrmann S, Miltner A, et al (2015) Fate of ectomycorrhizal fungal biomass in a soil bioreactor system and its contribution to soil organic matter formation. Soil Biol Biochem 88:120-127. doi: 10.1016/j.soilbio.2015.05.012

Smith DR, Townsend TJ, Choy AWK, et al (2012) Short-term soil carbon sink potential of oil palm plantations. GCB Bioenergy 4:588-596. doi: 10.1111/j.1757-1707.2012.01168.x

Soong JL, Fuchslueger L, Marañon-Jimenez S, et al (2020) Microbial carbon limitation: The need for integrating microorganisms into our understanding of ecosystem carbon cycling. Glob Chang Biol 26:1953-1961. doi: 10.1111/gcb.14962

Tao HH, Donough C, Hoffmann MP, et al (2017) Effects of best management practices on dry matter production and fruit production efficiency of oil palm. Eur J Agron 90:209-215. doi: 10.1016/j.eja.2017.07.008

Van Bruggen AHC, He MM, Shin K, et al (2018) Environmental and health effects of the herbicide glyphosate. Sci Total Environ 616-617:255-268. doi: 10.1016/j.scitotenv.2017.10.309

Wibawa W, Mohamad R, Juraimi AS, et al (2009) Weed control efficacy and short term weed dynamic impact of three Non-selective herbicides in immature oil palm plantation. Int J Agric Biol 11:145-150

Wickham H (2016) ggplot2: Elegant Graphics for Data Analysis. Springer Verlag. New York.

Woittiez LS, Turhina SRI, Deccy D, et al (2019) Fertiliser application practices and nutrient deficiencies in smallholder oil palm plantations in Indonesia. Exp Agric 55:543-559. doi: 10.1017/S0014479718000182

Zabaloy MC, Carné I, Viassolo R, et al (2016) Soil ecotoxicity assessment of glyphosate use under field conditions: Microbial activity and community structure of Eubacteria and ammonia-oxidising bacteria. Pest Manag Sci 72:684-691. doi: 10.1002/ps.4037

Zhou L, Zhou X, Zhang B, et al (2014) Different responses of soil respiration and its components to nitrogen addition among biomes: A meta-analysis. Glob Chang Biol 20:2332-2343. doi: $10.1111 / g c b .12490$ 


\section{APPENDIX}
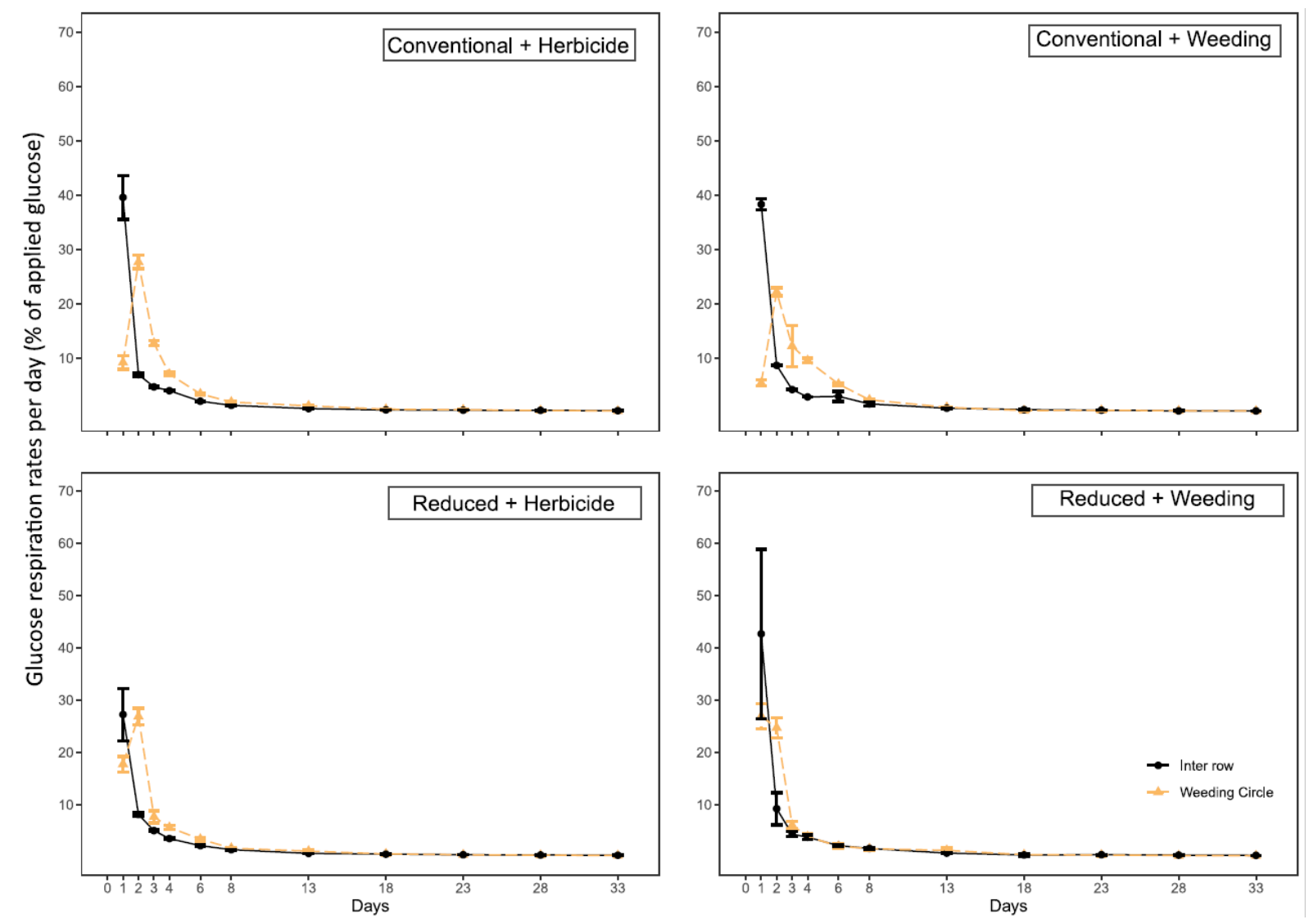

A 2.4-1: The rate of glucose respiration rates day ${ }^{-1}(\%)$ after glucose addition. Glucose was added once on day 0 , Measurements on day 1,2,3,4,6,8,13,18,23,28,33. Values are presented as means ( $n=4)$. Error bars indicate the standard error of the mean. 


\subsection{Abstracts of related studies}

\subsubsection{SOIL BACTERIAL COMMUNITY STRUCTURES IN RELATION TO DIFFERENT OIL PALM MANAGEMENT PRACTICES}

Dirk Berkelmann ${ }^{1 *}$, Dominik Schneider $^{1}, \underline{\text { Nina Hennings }}{ }^{2}$, Anja Meryandini ${ }^{3}$ and Rolf Daniel ${ }^{1}$ published in: Scientific Data (2020), 7, Article number 421, https://doi.org/10.1038/s41597-02000752-3

${ }^{1}$ Genomic and Applied Microbiology and Göttingen Genomics Laboratory, Institute of Microbiology and Genetics, Georg-August-University, Göttingen, Germany

${ }^{2}$ Department of Soil Science of Temperate Ecosystems, Buesgen Institute, Georg-AugustUniversity, Göttingen, Germany

${ }^{3}$ Department of Biology, Faculty of Mathematics and Natural Sciences IPB, Bogor Agricultural University, Bogor, Indonesia

* Corresponding author: Dirk Berkelmann 


\subsubsection{Abstract}

We provide soil bacterial 16S rRNA gene amplicon and geochemical data derived from an oil palm plantation management experiment. The experimental design covered two different intensities of fertilizer application and weeding practices. We sampled the topsoil of 80 plots in total and extracted DNA and RNA. The V3-V4 regions of the 16S rRNA genes and transcripts were amplified and sequenced with an Illumina MiSeq system. Sequences were quality-filtered and taxonomy was assigned using SILVA SSU NR 138 database as reference. One year after establishing the experiment, statistically significant differences of bacterial diversity or community composition between different treatments at entire (DNA-derived) and active (RNA-derived) community level were not detected. The most dominant taxa belonged to Acidobacteriota and Actinobacteriota and were more abundant at active than at entire community level. Similar results were obtained for the abundant genera Candidatus Solibacter and Haliangium. Furthermore, clustering corresponding to the different sampling site locations was recorded. This dataset is of interest for related studies on the effect of altered management practices on soilborne communities. 


\subsubsection{IMPROVING ECONOMIC AND ENVIRONMENTAL OUTCOMES IN OIL PALM SMALLHOLDINGS: THE EFFECTS OF MULCHING ON SOIL CARBON AND YIELDS}

Katrin Rudolf ${ }^{1 *}$, Nina Hennings ${ }^{2}$, Michaela A. Dippold ${ }^{2}$, Edi Edison ${ }^{3}$, Meike Wollni1,4

published in: Agricultural Systems (2021), Volume 193, 103242,

https://doi.org/10.1016/j.agsy.2021.103242

${ }^{1}$ Department of Agricultural Economics and Rural Development, University of Goettingen, Platz der Goettinger Sieben 5, 37073 Goettingen, Germany

${ }^{2}$ Division of Biogeochemistry of Agroecosystem, University of Goettingen, Buesgenweg 2, 37077 Goettingen, Germany

${ }^{3}$ University of Jambi, Jl Raya Jambi Muara Bulian KM 15, Jambi 36361, Indonesia

${ }^{4}$ Center of Biodiversity and Sustainable Land Use, University of Goettingen

${ }^{*}$ Corresponding author: Katrin Rudolf 


\subsubsection{Abstract}

CONTEXT: The area under oil palm cultivation has expanded importantly in South-East Asia. The resulting land-use transformations are associated with environmental degradation such as substantial carbon dioxide emissions. Soil conservation practices can contribute to more sustainable oil palm systems by increasing soil organic carbon (SOC) contents and yields. One soil conservation practice in oil palm plantations is the mulching with empty fruit bunches (EFB).

OBJECTIVE: We estimated the relationship between EFB mulching and, respectively, yields, SOC and total nitrogen contents, the carbon-nitrogen ratio and the average bulk density in smallholder oil palm plantations. We further analyzed the determinants of smallholders' EFB application taking into account regional market, farm, and plot level aspects, as well as farmers' perceptions.

METHODS: We estimated the relationship between mulching and yields with panel data, and between mulching and soil properties with cross-sectional data. We accounted for the possible selection bias of the decision to apply EFB mulching with instrumental variable estimations. Descriptive analysis was used to analyze the determinants of smallholder EFB use.

RESULTS AND CONCLUSIONS: Our results indicated that in particular the regional supply in EFB and farmers' wealth levels were correlated with smallholder EFB mulching. EFB mulching was associated with 39\% higher yields and 19\% higher SOC contents. We attribute the higher yields to potentially improved soil chemical functions linked to higher SOC contents, such cation exchange capacity effects, and to an increased $\mathrm{K}$ and potentially $\mathrm{Mg}$ availability. Since EFB is not available in sufficient quantity to be applied to all plantations, policy makers could identify user groups with the greatest potentials for environmental and income improvements. Site-specific life cycle assessments and yield effects can help to inform such identification.

SIGNIFICANCE: Despite their growing importance in the oil palm sector, evidence on the effect of EFB mulching was missing for smallholder farmers. Because of associated higher SOC contents and yields, our findings indicate that the promotion of EFB mulching as best management practice could potentially contribute to more sustainable oil palm systems. Strengthening inclusive value chains for smallholders, information provision and investments in road infrastructure represent potential policy instruments to increase smallholder EFB application. The identification and promotion of best management practices are important with view to the still ongoing oil palm expansion in South-East Asia, and progressively in other parts of the world. 


\subsection{Additional studies}

Pierre-André Waite, Bernhard Schuldt, Roman Mathias Link, Natalie Breidenbach, Triadiati Triadiati, Nina Hennings, Asmadi Saad, Christoph Leuschner (2019): Soil Moisture regime and palm height influence embolism resistance in oil palm. Tree Physiology, https://doi.org/10.1093/treephys/tpz061

Ingo Grass, Christoph Kubitza, Vijesh V. Krishna, Marife D. Corre, Oliver Mußhoff, Peter Pütz, Jochen Drescher, Katja Rembold, Eka Sulpin Ariyanti, Andrew D. Barnes, Nicole Brinkmann, Ulrich Brose, Bernhard Brümmer, Damayanti Buchori, Rolf Daniel, Kevin F.A. Darras, Heiko Faust, Lutz Fehrmann, Jonas Hein, Nina Hennings, Purnama Hidayat, Dirk Hölscher, Malte Jochum, Alexander Knohl, Martyna M. Kotowska, Valentyna Krashevska, Holger Kreft, Christoph Leuschner, Neil Jun S. Lobite, Rawati Panjaitan, Andrea Polle, Anton M. Potapov, Edwine Purnama, Matin Qaim, Alexander Röll , Stefan Scheu, Dominik Schneider, Aiyen Tjoa, Teja Tscharntke, Edzo Veldkamp \& Meike Wollni (2020): Trade-offs between multifunctionality and profit in tropical smallholder landscapes. Nature Communications, https://doi.org/10.1038/s41467-02015013-5 



\section{Acknowledgements}

Several persons contributed to the successful completion of this dissertation.

Mein besonderer Dank gilt meiner Doktormutter Prof. Dr. Michaela Dippold: durch ihr herausragendes Engagement konnte ich meine Doktorarbeit in der Bodenkunde fortsetzen und beenden. Es war wunderbar von ihr zu lernen, meine Arbeit mit ihr zu diskutieren und zu verbessern. Besonders ihre konstruktive und immer motivierende Arbeitsweise hat mich nachhaltig beeindruckt.

Ein außerordentlicher Dank geht an Prof. Dr. Yakov Kuzyakov, der mir die Möglichkeit gegeben hat diese Doktorarbeit $\mathrm{zu}$ schreiben und in Indonesien $\mathrm{zu}$ arbeiten. Seine Kommentare zu meinen Manuskripten waren besonders hilfreich.

Einen weiteren Dank möchte ich an Prof. Dr. Stefan Scheu aussprechen, für das inhaltliche Feedback meiner Arbeit bei den Komitee-Treffen und die Zweitbegutachtung dieser Dissertation.

Ein weiteres Dankeschön gilt Dr. Matthias Gube, für die Drittbetreuung meiner Doktorarbeit, das Lesen des 3. Papers und für die hilfreichen inhaltlichen Diskussionen.

Dr. Thomas Guillaume hat mich in der Einarbeitungsphase im Indonesienprojekt sowie bei der Interpretation des ${ }^{13} \mathrm{C}$ Datensatzes unterstützt. Merci beaucoup in die Schweiz!

Ein besonderer Dank geht an Dr. Joscha Becker für das Korrekturlesen zweier Manuskripte und für die wertvollen Hinweise bei den statistischen Auswertungen. Vielen Dank, dass du dir immer Zeit genommen hast mit mir inhaltlich zu diskutieren und deine wissenschaftlichen Erfahrungen mit mir zu teilen.

Für die Hilfe im Labor bei allen Experimenten und Analysen möchte ich mich ganz herzlich bei Susann Enzmann, Heike Strutz und Ingrid Ostermeyer bedanken. Ein besonderer Dank geht an Karin Schmitt für das Analysieren von und sehr vielen C, N Proben, sehr, sehr vielen CFE Proben und noch viel mehr $\mathrm{CO}_{2}$ Proben. Für das Einarbeiten im Labor für die free lipid Extraktionsmethode bedanke ich mich bei Josh Bostic und Dr. Callum Banfield. Ein weiteres Dankeschön geht an das Team vom Kompetenzzentrum für stabile Isotope (KOSI), das die Mmessung meines ${ }^{13} \mathrm{C}$ Proben übernommen hat. 
Many thanks go to Indonesia: Thanks to Megawati, Rizky, Yuking and Ibu Aiyen for all your support in Jambi: visa, cars, flights, housing, authorization letters, equipment, ... thanks a million! A special Terima kasih to Winda Januarista and Ardian. The summer of 2016 was also so amazing because it was the three of us exploring the Indonesian rainforest, rubber and oil palm plantations! During these months I learned so many things in science and beyond and I am very thankful that I could broaden my cultural and personal horizon. Further thanks go to Rico and Patrick, who made it easy for me to feel comfortable in Jambi. 2016 and 2017 in Indonesia will always stay in my heart as my special \& wonderful experience!

Das Indonesienprojekt ist auch deswegen eine tolle Gelegenheit zum Promovieren, weil wir so viele Doktoranden waren, die sich gegenseitig unterstützen konnten und mit denen man gleichzeitig eine tolle und spannende Zeit hatte: Danke an Jennifer Merten und Fenna Otten für die vielen Tipps am Anfang in Jambi und eure Freundschaft, die sich aus unserer gemeinsamen Zeit dort entwickelt hat! Joyson, Florian, Christian, Britta, Katrin und Dirk für die gemeinsamen Projekte innerhalb des SFBs 990 und die schönen Abende ganz ohne Wissenschaft!

Vielen lieben Dank an die Bodenbuddler-Crew aus dem Büsgenweg 2: Nataliya, Sara und Baxter (für viel mehr als nur das Teilen eines Büros \& jedes Büro braucht einen Baxter!), Moritz, Katharina (danke für deine Unterstützung im Labor, das gemeinsame Mittagessenkochen), Magnus (für das Mahlen und Einwiegen von unendlich vielen Proben), und die shut-up-and-write Gruppe mit Andy, Svenja und Maire: es ist schön euch zu haben! Mein besonderer Dank fürs Korrekturlesen, die gemeinsamen Abende und die vielen geteilten Momente!

Nicht Boden aber trotzdem in der Wissenschaft: für Abende voller großer Gedanken und Lachen ein großes Dankeschön an meine tolle WG: Corinna und Jonas!

Mein größtes Dankeschön geht an meine Familie: meine Eltern, meine Schwester und Jens (auch für die unglaublichen Excel Tricks und die R Puzzelei!), die immer für mich da sind, auf die ich mich immer verlassen kann und die mich in allem was ich mir vornehme, unterstützen. 


\section{Legal Statement}

Hiermit erkläre ich, dass diese Arbeit weder in gleicher noch in ähnlicher Form bereits anderen Prüfungsbehörden vorgelegen hat und ich mich an keiner anderen Hochschule um einen Doktorgrad beworben habe. Weiter erkläre ich eidesstattlich, dass diese Dissertation selbstständig und ohne unerlaubte Hilfe angefertigt wurde.

Göttingen, den

(Unterschrift) 